The descriptions of sites, cores, and data included in these site reports were completed within one year of the cruise, but many of the topical chapters that follow were completed at a later date. More data were acquired and authors' interpretations matured during this interval, so readers may find some discrepancies between site reports and topical papers. The timely publication of the Initial Reports series, which is intended to report the early results of each leg, precludes incurring the delays that would allow the site reports to be revised at a later stage of production. 


\title{
2. SITE 586: WESTERN EQUATORIAL PACIFIC ${ }^{1}$
}

\author{
Shipboard Scientific Parties of Legs 89 and $90^{2}$
}

\section{HOLE 586}

Date occupied: 19 November 1982

Date departed: 19 November 1982

Time on hole: $15 \mathrm{hr}$, $52 \mathrm{~min}$.

Position: $00^{\circ} 29.84^{\prime} \mathrm{S} ; 158^{\circ} 29.89^{\prime} \mathrm{E}$

Water depth (sea level; corrected m, echo-sounding): 2208

Water depth (rig floor; corrected m, echo-sounding): 2218

Bottom felt (m, drill pipe): 2223.1. Note: water depth of $2218 \mathrm{~m}$ from rig floor from $586 \mathrm{C}$ logs used as site datum.

Penetration (m): 39.3

Number of cores: 5

Total length of cored section (m): 39.3

Total core recovered $(\mathrm{m}): 38.98$

\footnotetext{
${ }^{1}$ Kennett, J. P., von der Borch, C. C., et al., Init. Repts. DSDP, 90: Washington (U.S. Govt, Printing Office).

2 Holes $586,586 \mathrm{~A}$, and $586 \mathrm{C}$ have been described by the Leg 89 shipboard scientific party, Hole 586B by the Leg 90 shipboard scientific party. Both are, therefore, listed here.

Leg 89: Ralph Moberly (Co-Chief Scientist), Hawaii Institute of Geophysics, University of Hawaii, Honolulu, HI 96822; Seymour O. Schlanger (Co-Chief Scientist), Department of Geological Sciences, Northwestern University, Evanston, IL 60201; Miriam Baltuck, Deep Sea Drilling Project, Scripps Institution of Oceanography, La Jolla, CA 92093 (present address: Geology Department, Tulane University, New Orleans, LA 70118); James A. Bergen, Depertment of Geology, Florida State University, Tallahassee, FL 32306; Walter Dean, U.S. Geological Survey, Denver Federal Center, Denver, CO 80225; Peter A. Floyd, Department of Geology, University of Keele, Keele, Staffordshire STS 5BG, United Kingdom; Naoyuki Fujii, Department of Earth Sciences, Kobe University, Kobe 657, Japan; Janet A. Haggerty, Department of Geosciences, University of Tulsa, Tulsa, OK 74104; James G. Ogg, Department of Geology and Geophysics, University of Wyoming, Laramie, WY (present address: Scripps Institution of Oceanography, La Jolla, CA 92093); Isabella Premoli Silva, Istituto di Paleon(1) G. Schaefer, Institut für Erdöl und Organische Geochemie, KFA Jülich, GmbH, Postfach 1913, D-5170 Jülich, Federal Republic of Germany; William V. Sliter, Branch of Paleontology and Stratigraphy, U.S. Geological Survey, Reston, VA (present address: U.S. Geological Survey, 345 Middlefield Rd., Menlo Park, CA 94025); Jill M. Whitman, Geological Research Division, Scripps Institution of Oceanography, La Jolla, CA 92093.
}

Leg 90: James P. Kennett (Co-Chief Scientist), Graduate School of Oeanography, University of Rhode Island, Narragansett, RI 02882; Christopher C. von der Borch (Co-Chief Scientist), School of Earth Sciences, Flinders University of South Australia, Bedford Park, South Australia 5042; Paul A. Baker, Department of Geology, Duke University, Durham, NC 27708; Charles E. Barton, Graduate School of Oceanography, University of Rhode Island, Narragansett, RI 02882 (present address: Bureau of Mineral Resources, Geology, and Geophysics, P.O. Box 378, Canberra, A.C.T., Australia); Anne Boersma, Microclimates, Inc., 404 RR1, Stony Point, NY 10980; Jean-Pierre Caulet, Laboratoire de Géologie, Muséum National d'Histoire Naturelle, 43 Rue Buffon, 75005, Paris, France; Walter C. Dudley, Jr., Natural Sciences Division, College of Arts and Sciences, University of Hawaii at Hilo, Hilo, Ha waii 96720; James V. Gardner, Pacific-Arctic Branch of Marine Geology, US. Geological SurSciences, Open University, Walton Hall, Milton Keynes, MK7 6AA, Buckinghamshire, United Kingdom; William H. Lohman, Marathon Oil Co., Denver Research Center, P.O. Box 269, Littleton, CO 80160; Erlend Martini, Geologisch-Paläontologisches Institut, JohannWolfgang-Geothe Universitåt, Senckenberg-Anlage 32-34, D-6000 Frankfurt am Main, Federal Republic of Germany; Russell B. Merrill, Deep Sea Drilling Project A031, Scripps Institution of Oceanography, La Jolla, CA 92093 (present address: Ocean Drilling Project, Texas A\&M University, College Station. TX 77843-3469): Roger Morin, Department of Earth and Planetary Sciences, Massa 225): Cambell S. Nelson, Department of Earth Sciences, University of Waikato, Private Bag, Hamilton, New Zealand; Christian Robert, Laboratoire de Géologie Marine, Centre Universitaire de Luminy, Case 901, 13288 Marseille Cedex 09, France; M. S. Srinivasan, Department of Geology, Banaras Hindu University, Varanasi 221005 , India; Rüdiger Stein, Geologisch-Paläontologisches Institut, Universităt Kiel, 2300 Kiel, Federal Republic of Germany (present address: Institute of Petroleum and Organic Geochemistry (ICH-5). Kernforschungslage Jülich $\mathrm{GmbH}$ P.O. Box 1913, 5170 Jölich, Federal Republic of Germany); Akira Takeuchi, Department of Earth Sciences, Faculty of Science, Toyama University, Gohuku 3190, Toyama 930, Japan.
Core recovery (\%): 99.2

Oldest sediment cored:

Depth sub-bottom (m): 39.3

Nature: Foraminifer-bearing nannofossil ooze

Age: Latest Pliocene

Measured velocity $(\mathrm{km} / \mathrm{s})$ : Not measured

Basement: Not encountered

Principal results: This was to be the first of two overlapping sets of cores obtained by the hydraulic piston corer (HPC) on the edge of the Ontong-Java Plateau. While we were attempting to retract the barrel of Core 6, the barrel broke and was left outside the bit, forcing early abandonment of the hole.

\section{HOLE 586A}

Date occupied: 19 November 1982

Date departed: 20 November 1982

Time on hole: 1 day, 3 hr., $46 \mathrm{~min}$.

Position: $00^{\circ} 29.84^{\prime} \mathrm{S} ; 158^{\circ} 29.89^{\prime} \mathrm{E}$

Water depth (sea level; corrected m, echo-sounding): 2208

Water depth (rig floor; corrected $\mathrm{m}$, echo-sounding): 2218

Bottom felt (m, drill pipe): Not felt. Note: water depth of $2218 \mathrm{~m}$ from rig floor from $586 \mathrm{C}$ logs used as site datum.

Penetration (m): 305.3

Number of cores: 31

Total length of cored section (m): 260.9

Total core recovered $(\mathrm{m}): 257.03$

Core recovery $(\%): 98.5$

Oldest sediment cored:

Depth sub-bottom (m): 305.3

Nature: Nannofossil ooze and minor nannofossil chalk

Age: Earliest late Miocene

Measured velocity $(\mathrm{km} / \mathrm{s}): 1.6$

Basement: Not encountered

Principal results: Hole 586A was washed to the $39.3 \mathrm{~m}$ depth at which Hole 586 had to be abandoned. A Neogene section of foraminiferbearing nannofossil ooze was recovered. With depth, foraminifer content decreases. Below $260 \mathrm{~m}$ the first thin chalk beds appear and foraminifers are few. Fossils examined from this site show a mixture of two components: whole specimens whose age increases with core depth, and broken and corroded specimens reworked and transported to the site.

\section{HOLE 586B}

Date occupied: 20 November 1982

Date departed: 22 November 1982

Time on hole: 1 day, 1 hr., $3 \mathrm{~min}$.

Position: $00^{\circ} 29.84^{\prime} \mathrm{S} ; 158^{\circ} 29.89^{\prime} \mathrm{E}$

Water depth (sea level; corrected m, echo-sounding): 2208 
Water depth (rig floor; corrected $\mathbf{m}$, echo-sounding): 2218

Bottom felt (m, drill pipe): At or above 2219.4. Note: water depth of $2218 \mathrm{~m}$ from rig floor from $586 \mathrm{C}$ logs used as site datum.

Penetration (m): 240.3

Number of cores: 25

Total length of cored section (m): 240.3

Total core recovered $(\mathrm{m}): 234.93$

Core recovery $(\%): 97.8$

Oldest sediment cored:

Depth sub-bottom (m): 240.3

Nature: Foraminifer-bearing nannofossil ooze

Age: Late Miocene

Basement: Not encountered

Principal results: (by Leg 90 shipboard scientific party): This hole duplicated the upper $240 \mathrm{~m}$ at Site 586 . It is a continuous, uncomplicated section from Quaternary to early late Miocene age, differing only in details from descriptions of Holes 586 and 586A. However, unlike the findings reported for Hole 586, there is little evidence of extensive reworking or turbidite layers. The hole terminated after an equipment failure (HPC piston) at $240.3 \mathrm{~m}$.

\section{HOLE 586C}

Date occupied: 22 November 1982

Date departed: 23 November 1982

Time on hole: 1 day, $8 \mathrm{hr}$, $2 \mathrm{~min}$.

Position: $00^{\circ} 29.84^{\prime} \mathrm{S}$; $158^{\circ} 29.89^{\prime} \mathrm{E}$

Water depth (sea level; corrected m, echo-sounding): 2208

Water depth (rig floor; corrected m, echo-sounding): 2218

Bottom felt (m, drill pipe): Not felt; $2218 \mathrm{~m}$ by gamma logs

Penetration (m): 623.1

Number of cores: 1

Total length of cored section $(\mathrm{m}): 9.6$

Total core recovered $(\mathrm{m}): 2.18$

Core recovery $(\%): 23$

Oldest sediment cored:

Depth sub-bottom (m): 623.1

Nature: Nannofossil chalk and ooze

Age: early Miocene

Measured velocity $(\mathrm{km} / \mathrm{s})$ : -

Basement: Not encountered

Principal results: Drilled to provide hole for logging thick section of carbonate ooze. Obtained suite of excellent logs.

\section{BACKGROUND AND OBJECTIVES}

The 1981-1983 Glomar Challenger drilling plan included three traverses designed to provide detailed information about Neogene paleoceanography and biostratigraphy through the recovery of sets of relatively complete and undisturbed cores of highly fossiliferous deep-sea sediment. The seafloor below areas of moderate to high productivity and above the carbonate compensation depth (CCD) allows calcareous foraminifers and nannofossils to accumulate and remain in a good state of preservation. Of the three traverses in areas of thick Neogene calcareous ooze, Leg 85 cored sites in the eastern equatorial Pacific, where cyclic productivity presumably controls cyclic sedimentation, and Leg 94 cored sites in the eastern North Atlantic to examine paleoceanographic changes across latitudinal belts.

A third series of sites extends across latitudinal oceanographic boundaries in the southwest Pacific. Broad areas of the seafloor elevated well above the CCD extend, with interruptions, from the Ontong-Java Plateau at the equator, past various rises between Melanesia and Australia, to the Bounty Trough, between Chatham Rise and Campbell Plateau, east of New Zealand. Boundaries of water masses may have shifted in response to changes in ocean circulation, owing to changing positions of land masses as the Australian lithospheric plate moved northward and the Melanesian island arcs evolved. Particular assemblages of fossil plankton characterize the various water masses between the equator and the Antarctic. Changes through time in the assemblages of ecologically dependent fossils at a drilling site are the records of past oceanographic changes there. The objective of Leg 90 was to use the HPC at several of these Neogene pelagic sites. JOIDES Planning Committee, however, assigned the northernmost site, SW-9, to Leg 89 to reduce the total amount of Leg 90 travel time.

SW-9 (Site 586) is the tropical end of the traverse. It lies on the northeastern upper slope of the Ontong-Java Plateau on a broad northeast-trending ridge between two swales that are the heads of submarine canyon systems. Although mass wasting at the plateau margins has been documented, and regional surveys suggest that a more complete section lies near the crest of the plateau 200 to $300 \mathrm{~km}$ to the southwest, Site 586 is located near existing DSDP Site 289 at $00^{\circ} 29.92^{\prime} \mathrm{S}, 158^{\circ} 30.69^{\prime} \mathrm{E}$ (Fig. 1). During Leg 30 that site was cored by a rotary bit continuously for $1262.5 \mathrm{~m}$, with $56 \%$ average recovery, through Cenozoic and Cretaceous sediments into basaltic basement of Aptian or earlier age (Andrews, Packham, et al., 1975). The JOIDES Ocean Paleoenvironment Panel chose to schedule the HPC site at an existing continuously cored site in order to have a standard section that could be pieced together from the work of the two legs, rather than at spot-cored DSDP Site 64 (which

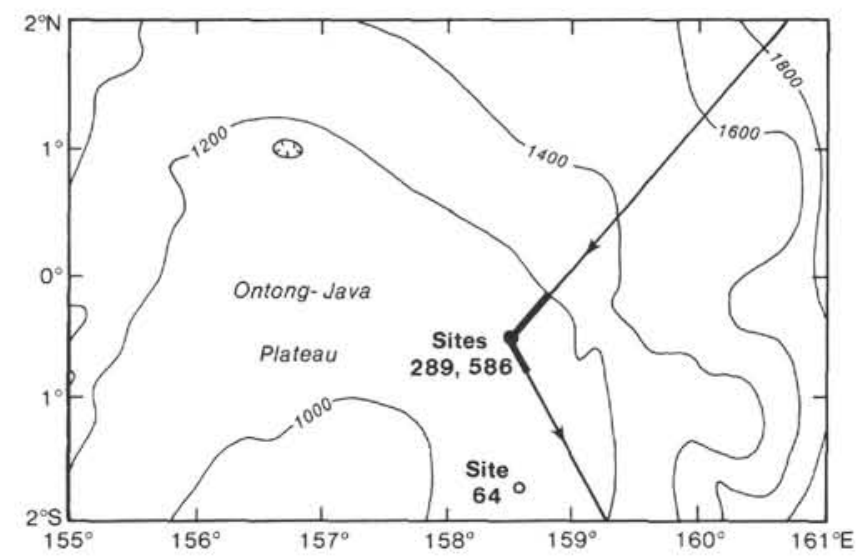

Figure 1. Regional bathymetry (fathoms) around Site 586, within one nautical mile of Site 289 on the northeast flank of the Ontong-Java Plateau. Challenger Leg 89 track shown; heavy portion locates water gun seismic profile illustrated in Fig. 2. Bathymetry after Mammerickx et al., 1974. 
terminated in the Eocene) or at a new site that might not reach basement. Moreover, even though the Site $289 \mathrm{Ne}-$ ogene cores were disturbed and not complete in their recovery, so that HPC cores were needed for detailed work, they did not show any major discontinuities in the section above the lower Oligocene. The upper Oligocene and Miocene section is about $750 \mathrm{~m}$ thick at Site 289 .

The principal aim at Site 586, therefore, was to obtain piston cores using the HPC to about $250 \mathrm{~m}$ depth or shallower, in the event that the resistance to shear by the sediment as it consolidated under burial increased to the degree that penetration died off significantly. Then, a second hole at the site was to be cored, offset slightly in distance and with the depth intervals of the second set of HPC cores adjusted so as to place the midpoints of the second set opposite the depths of the tops and bottoms of the first set. The pair of HPC holes, with overlapping cored intervals, was thereby expected to provide a continuous record: gaps in one set of cores should be filled by recovery in the other set. According to the Leg 30 paleontology report, $250 \mathrm{~m}$ depth would be within the upper Miocene, and it was expected that we would acquire a good record of late Neogene oceanographic events in the tropical belt of the western Pacific.

Of the lesser objectives for Site 586, the Leg 89 scientific party attempted as many as could be fitted into the time remaining for the leg. The cause for the widespread, closely spaced seismic reflectors (Fig. 2) common in the carbonate oozes and chalks of oceanic plateaus has been studied on the Ontong-Java Plateau (Winterer, Riedel, et al., 1971; Moberly and Heath, 1971; van der Lingen and Packham, 1975) and elsewhere (Schlanger and Douglas, 1974). Laboratory studies of physical properties of Site 289 samples by Milholland et al., 1980 are the most refined ones to date. There was no logging, however, at Site 289 , and for Leg 89 it was planned, if time permitted after the HPC, to drill into the ooze/ chalk transition and $\log$ that hole. Density and velocity logs would give the opportunity to relate the petrography and laboratory-determined physical properties of specimens with downhole measurements of their geophysical parameters. Further, the logs could be processed so that real reflectors could be distinguished from acoustic artifacts. By dating these reflectors paleontologically by their depths in Hole 289, it would then be possible to confirm or reject the hypothesis that reflectors represent paleoceanographic events.

Other objectives of secondary importance included sampling for organic geochemistry, for paleomagnetism, and for diatom biostratigraphy. Periodic use of the heatflow probe would allow a geothermal gradient to be determined. The origin of the Ontong-Java Plateau and of other oceanic plateaus remains controversial, and every type of high-quality geophysical information is of great value. Finally, if time remained during drilling of the logging hole, it was planned to take some cores from the lower Miocene interval to attempt to resolve a conflict between nannofossil and foraminifer correlations in the lower Miocene of the Pacific area.

Most of the detailed studies of Site 586 material have been made by the Leg 90 Scientific Party and appear in this volume of the Initial Reports.

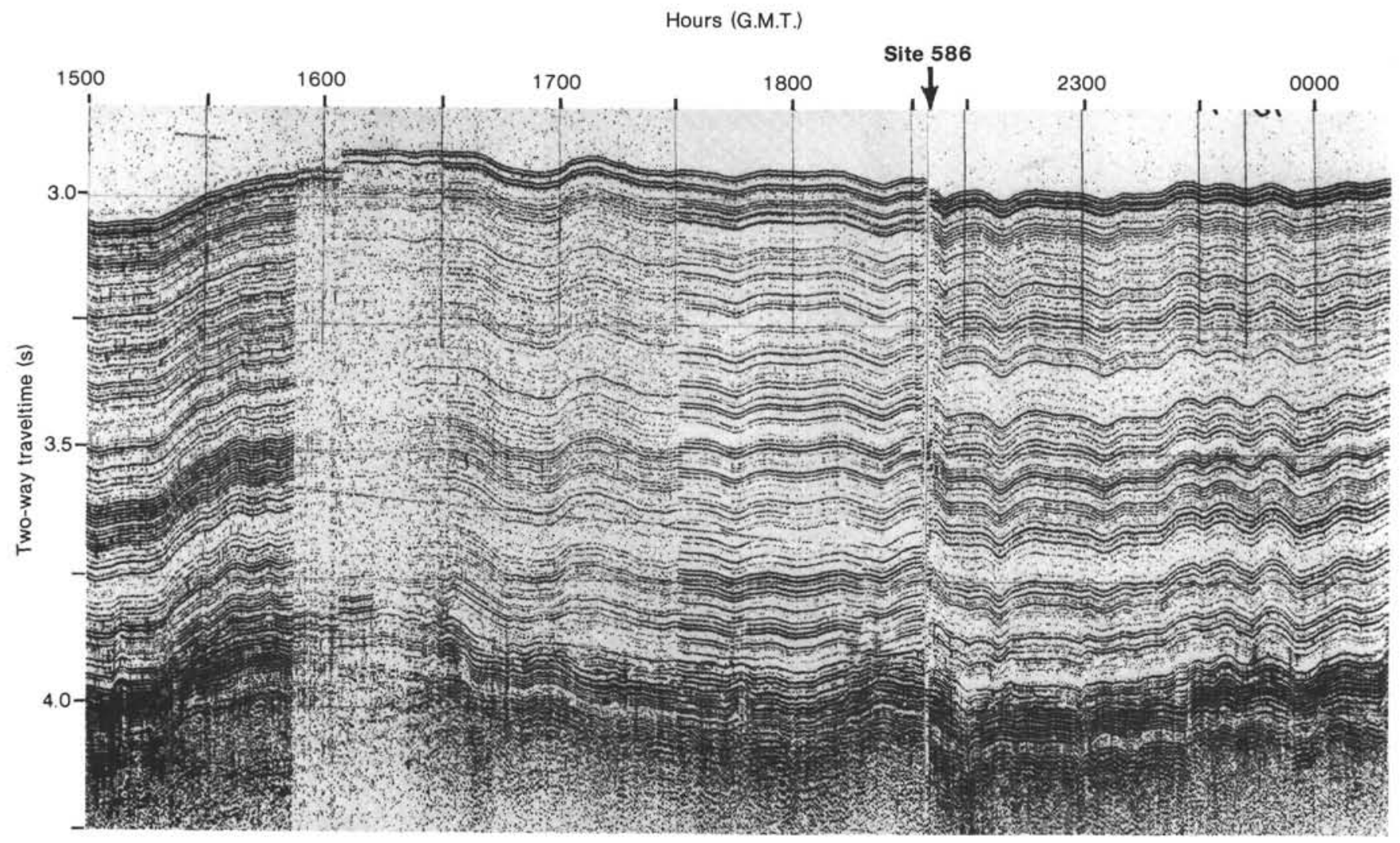

Figure 2. Water gun seismic profile (Glomar Challenger) near Site 586. 


\section{OPERATIONS}

The Glomar Challenger's route southwest from Site 462 generally traversed the bathymetric slope that rises up from the Nauru Basin onto the Ontong-Java Plateau. Clear sight of Kusaie (Kosroe) Island and the profiler records of crossings of some of the distributary channels between the plateau and basin confirmed our conclusions about the sources of young ash and reworked Cenozoic fossils that are so abundant in the upper part of the Nauru Basin section at Site 462 .

As we approached the position of Site 289 we slowed to 7 knots to improve the seismic reflection record (Fig. 2). There was no need to reoccupy the exact spot of the site, and so the beacon was dropped on a dead reckoning position at $0527 \mathrm{hr}$. on 19 November. The water depth, corrected from the PDR, was $2207 \mathrm{~m}$. Later, satellite navigation fixes showed that Site 586 is about 1300 m westnorthwest of Site 289 . The surveying gear was retrieved and the drilling crew commenced to assemble the components for using a variable length hydraulic piston corer (VLHPC) and lowering the drill string.

On the assumption that the seafloor was $2217 \mathrm{~m}$ from the drill floor, and taking into account the height of drill pipe joints above the rotary table (for ease in adding new lengths of pipe), the first core was triggered from $2214.8 \mathrm{~m}$. When it was retrieved on board at $1420 \mathrm{hr}$., only the lower $1.3 \mathrm{~m}$ of the $9.6 \mathrm{~m}$ "shot" held sediment. The uppermost few centimeters of the core showed brownish colors, indicative of oxidation to the depth of burrowing at the seafloor, above the generally pale greenish colors of reduced pigment in the rest of that core (and of subsequent cores). The sediment/water interface would have been established at $2223.1 \mathrm{~m}$ below the drill floor (2213 m below sea level), but the PDR record already mentioned, the Core 586B-1 recovery, and Hole 586C logging indicate that $2218 \mathrm{~m}$ below drill floor $(2208 \mathrm{~m}$ below sea level) is a more correct value for all holes at this site. ${ }^{3}$

Four more cores with virtually complete recovery $(99.2 \%)$ were easily and speedily obtained from the foraminifer-bearing nannofossil ooze (Table 1). Only the upper half of the sixth core barrel, however, came back on deck, at $1919 \mathrm{hr}$. on the same afternoon. After the VLHPC inner barrel had been shot hydraulically from its core barrel housing down through the hole in the bit and out into the ooze, it broke off from the barrel and was lost in the sediment. The Von Herzen heat-flow probe with its miniaturized electronics and battery packages was left in the shoe of the lost inner barrel. Because that was the only remaining probe, the heat-flow program ended. The five cores recovered were not oriented, owing to malfunctioning of the Kuster single-shot system.

After that termination of Hole 586, the drill string was raised slightly, then lowered, and Hole $586 \mathrm{~A}$ was started by washing to the $39.3 \mathrm{~m}$ total depth of the first hole. The broken VLHPC was repaired and put to use. The first 25 cores were retrieved from $586 \mathrm{~A}$ at an aver-

\footnotetext{
${ }^{3}$ Note that prime data for Holes 586 and $586 \mathrm{~A}$ collected aboard ship may reflect the originally established water depths and sub-bottom depths and may be in error by $5.1 \mathrm{~m}$ in the sub-bottom depths.
}

Table 1. Coring summary, Site 586.

\begin{tabular}{|c|c|c|c|c|c|c|c|}
\hline \multirow{2}{*}{$\begin{array}{l}\text { Core } \\
\text { no. }\end{array}$} & \multirow{2}{*}{$\begin{array}{l}\text { Date } \\
\text { (Nov. } \\
\text { 1982) }\end{array}$} & \multirow[b]{2}{*}{ Time } & $\begin{array}{l}\text { Depth from } \\
\text { drill floor } \\
\text { (m) }\end{array}$ & \multirow{2}{*}{$\begin{array}{l}\text { Depth below } \\
\text { seafloor } \\
\text { (m) } \\
\text { Top Bottom }\end{array}$} & \multirow{2}{*}{$\begin{array}{l}\text { Length } \\
\text { cored } \\
\text { (m) }\end{array}$} & \multirow{2}{*}{$\begin{array}{l}\text { Length } \\
\text { recovered } \\
\text { (m) }\end{array}$} & \multirow{2}{*}{$\begin{array}{l}\text { Percentage } \\
\text { recovered }\end{array}$} \\
\hline & & & Top Bottom & & & & \\
\hline \multicolumn{8}{|c|}{ Hole 586} \\
\hline 1 & 19 & 1420 & $2218.0-2224.4$ & $0.0-1.3$ & 1.3 & 1.28 & 98.5 \\
\hline 2 & 19 & 1527 & $2224.4-2233.9$ & $1.3-10.8$ & 9.5 & 9.52 & 100.2 \\
\hline 3 & 19 & 1608 & $2233.9-2243.4$ & $10.8-20.3$ & 9.5 & 9.44 & 99.4 \\
\hline 4 & 19 & 1701 & $2243.4-2252.9$ & $20.3-29.8$ & 9.5 & 9.68 & 101.9 \\
\hline \multirow[t]{2}{*}{5} & 19 & 1742 & $2252.9-2262.4$ & $29.8-39.3$ & 9.5 & 9.06 & 95.4 \\
\hline & & & & & 39.3 & 38.98 & 99.2 \\
\hline
\end{tabular}

Hole $586 \mathrm{~A}$ (wash to $39.3 \mathrm{~m}$ )

$\begin{array}{rrrr}1 & 19 & 2305 & 2262.4-2272.0 \\ 2 & 19 & 2349 & 2272.0-2281.6 \\ 3 & 20 & 0043 & 2281.6-2291.2 \\ 4 & 20 & 0125 & 2291.2-2300.8 \\ 5 & 20 & 0155 & 2300.8-2310.4 \\ 6 & 20 & 0237 & 2310.4-2320.0 \\ 7 & 20 & 0316 & 2320.0-2329.6 \\ 8 & 20 & 0400 & 2329.6-2339.2 \\ 9 & 20 & 0445 & 2339.2-2348.8 \\ 10 & 20 & 0523 & 2348.8-2358.4 \\ 11 & 20 & 0602 & 2358.4-2368.0 \\ 12 & 20 & 0640 & 2368.0-2377.6 \\ 13 & 20 & 0730 & 2377.6-2384.9 \\ 14 & 20 & 0815 & 2384.9-2389.8 \\ 15 & 20 & 0900 & 2389.8-2398.8 \\ 16 & 20 & 0940 & 2398.8-2408.4 \\ 17 & 20 & 1022 & 2408.4-2418.0 \\ 18 & 20 & 1105 & 2418.0-2427.6 \\ 19 & 20 & 1140 & 2427.6-2436.1 \\ 20 & 20 & 1230 & 2436.1-2445.7 \\ 21 & 20 & 1305 & 2445.7-2455.3 \\ 22 & 20 & 1340 & 2455.3-2464.9 \\ 23 & 20 & 1430 & 2464.9-2474.5 \\ 24 & 20 & 1512 & 2474.5-2484.1 \\ 25 & 20 & 1607 & 2484.1-2493.7 \\ 26 & 20 & 1645 & 2493.7-2499.7 \\ 27 & 20 & 1750 & 2499.7-2503.9 \\ 28 & 20 & 1908 & 2503.9-2508.3 \\ 29 & 20 & 1955 & 2508.3-2513.3 \\ 30 & 20 & 2050 & 2513.3-2518.3 \\ 31 & 20 & 2130 & 2518.3-2523.3 \\ & & & \end{array}$

\begin{tabular}{rrrr}
$39.3-48.9$ & 9.6 & 9.45 & 98.4 \\
$48.9-58.5$ & 9.6 & 9.44 & 98.3 \\
$58.5-68.1$ & 9.6 & 9.57 & 99.7 \\
$68.1-77.7$ & 9.6 & 9.54 & 99.4 \\
$77.7-87.3$ & 9.6 & 9.38 & 97.7 \\
$87.3-96.9$ & 9.6 & 9.37 & 97.6 \\
$96.9-106.5$ & 9.6 & 9.52 & 99.2 \\
$106.5-116.1$ & 9.6 & 9.50 & 99.0 \\
$116.1-125.7$ & 9.6 & 9.50 & 99.0 \\
$125.7-135.3$ & 9.6 & 9.40 & 97.9 \\
$135.3-144.9$ & 9.6 & 9.52 & 99.2 \\
$144.9-154.5$ & 9.6 & 9.56 & 99.6 \\
$154.5-161.8$ & 7.3 & 7.30 & 100.0 \\
$161.8-166.7$ & 4.9 & 4.87 & 99.4 \\
$166.7-175.7$ & 9.0 & 9.03 & 100.3 \\
$175.7-185.3$ & 9.6 & 9.56 & 99.6 \\
$185.3-194.9$ & 9.6 & 9.44 & 98.3 \\
$194.9-204.5$ & 9.6 & 9.48 & 98.8 \\
$204.5-213.0$ & 8.5 & 8.54 & 100.5 \\
$213.0-222.6$ & 9.6 & 9.22 & 96.0 \\
$222.6-232.2$ & 9.6 & 9.84 & 102.5 \\
$232.2-241.8$ & 9.6 & 9.50 & 99.0 \\
$241.8-251.4$ & 9.6 & 9.57 & 99.7 \\
$251.4-261.0$ & 9.6 & 9.57 & 99.7 \\
$261.0-270.6$ & 9.6 & 9.47 & 98.6 \\
$270.6-276.6$ & 6.0 & 4.14 & 69.0 \\
$276.6-280.8$ & 4.2 & 4.15 & 98.8 \\
$280.8-285.2$ & 4.4 & 4.26 & 96.8 \\
$285.2-290.2$ & 5.0 & 5.08 & 101.6 \\
$290.2-295.2$ & 5.0 & 5.15 & 103.0 \\
$295.2-300.2$ & 5.0 & 5.11 & 102.2 \\
\hline & 260.9 & 257.03 & 98.5
\end{tabular}

Hole 586B

$\begin{array}{rrrr}1 & 21 & 0200 & 2219.4-2229.0 \\ 2 & 21 & 0320 & 229.0-2238.6 \\ 3 & 21 & 0410 & 2238.6-2248.2 \\ 4 & 21 & 0500 & 2248.2-2257.8 \\ 5 & 21 & 0545 & 2257.8-2267.4 \\ 6 & 21 & 0630 & 2267.4-2277.0 \\ 7 & 21 & 0715 & 2277.0-2286.6 \\ 8 & 21 & 0800 & 2286.6-2296.2 \\ 9 & 21 & 0840 & 2296.2-2305.8 \\ 10 & 21 & 0916 & 2305.8-2314.3 \\ 11 & 21 & 0950 & 2314.3-2323.9 \\ 12 & 21 & 1025 & 2323.9-2333.5 \\ 13 & 21 & 1110 & 2333.5-2343.1 \\ 14 & 21 & 1145 & 2343.1-2352.7 \\ 15 & 21 & 1220 & 2352.7-2362.3 \\ 16 & 21 & 1300 & 2362.3-2371.9 \\ 17 & 21 & 1348 & 2371.9-2381.5 \\ 18 & 21 & 1430 & 2381.5-2391.1 \\ 19 & 21 & 1513 & 2391.1-2400.7 \\ 20 & 21 & 1550 & 2400.7-2410.3 \\ 21 & 21 & 1628 & 2410.3-2419.9 \\ 22 & 21 & 1710 & 2419.9-2429.5 \\ 23 & 21 & 1749 & 2429.5-2439.1 \\ 24 & 21 & 1837 & 2439.1-2448.7 \\ 25 & 21 & 1910 & 2448.7-2458.3\end{array}$

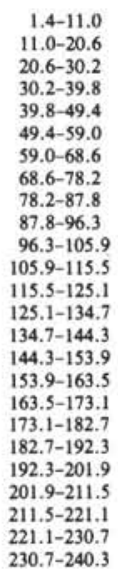

\begin{tabular}{rrr}
9.6 & 9.62 & 100 \\
9.6 & 9.49 & 99 \\
9.6 & 9.66 & 100 \\
9.6 & 9.31 & 97 \\
9.6 & 9.36 & 98 \\
9.6 & 9.62 & 100 \\
9.6 & 9.10 & 95 \\
9.6 & 9.61 & 100 \\
9.6 & 9.64 & 100 \\
8.5 & 8.01 & 94 \\
9.6 & 9.70 & 100 \\
9.6 & 9.63 & 100 \\
9.6 & 9.69 & 100 \\
9.6 & 9.63 & 100 \\
9.6 & 9.47 & 99 \\
9.6 & 9.41 & 98 \\
9.6 & 9.05 & 94 \\
9.6 & 9.60 & 100 \\
9.6 & 9.60 & 100 \\
9.6 & 9.54 & 99 \\
9.6 & 9.55 & 99 \\
9.6 & 9.63 & 100 \\
9.6 & 9.68 & 100 \\
9.6 & 8.89 & 93 \\
9.6 & 8.44 & 88 \\
\hline 240.3 & 234.93 & 98
\end{tabular}

Hole $586 \mathrm{C}$

$\begin{array}{rllllllll}\mathrm{H} 1 & 22 & 1255 & 2218.0-2831.5 & 0.0-613.5 & \overline{9} & \overline{2.18} & \overline{23} \\ \mathrm{I} & 22 & 1350 & 2831.5-2841.1 & 613.5-623.1 & \frac{9.6}{2.18} & & \end{array}$

Note: Data in this table have been corrected to accord with the water depth of $2218 \mathrm{~m}$ established by logging at Hole $586 \mathrm{C}$.

age interval of $40 \mathrm{~min}$. from these shallow depths. Virtually all of these cores attempted a full $9.6 \mathrm{~m}$ stroke and recovered a full barrel. By $270.6 \mathrm{~m}$ coring depth, the frictional resistance to withdrawal of the core barrel from the sediment reached 30,000 to $50,000 \mathrm{lb}$., and so 
to lessen the risk of structural failure of the tool again, the driller shifted to the use of a 5-m-stroke HPC. The last four cores, ending with Core 31 at $300.2 \mathrm{~m}$ total depth, were so taken, with excellent results. Coincidentally, the Kuster system provided orientation data for the last cores. Overall there was $98.5 \%$ recovery from Hole 586A. The calcareous oozes and, below $230 \mathrm{~m}$, a few thin chalk beds had cored easily. A few more cores probably could have been recovered, but the drill string was pulled up above the seafloor at $0008 \mathrm{hr}$. on 22 November to maintain the schedule for the site.

After redressing the VLHPC, the crew commenced coring Hole 586B, which was, as earlier noted, to be a duplicate of the 586-586A section, with overlapping depths of individual cores. The first core was shot from $2119.4 \mathrm{~m}$ depth, presumably slightly above the $2223.1 \mathrm{~m}$ seafloor, with the intention of recovering $5.9 \mathrm{~m}$. The entire $9.6 \mathrm{~m}$ barrel, however, was recovered full of sediment, raising the question about the true depth of the seafloor. Again, coring proceeded quickly, with 25 cores obtained in a 17-hr. span. Actually, there were 26 wire line trips in that time; Core 2 had to be repeated when the core catcher failed to close. Orientation was good for these cores; except for the leakage of light, which fogged parts of the film, the Kuster device was working.

When the 25th core was brought on board during the evening of 21 November, it was discovered that the piston had jammed tightly inside the top of the core barrel, because the plastic core liner had collapsed. The lengthy process of removing the core from the barrel, and the additional time that would be needed to remove the piston and redress the tool, caused us to abandon Hole 586B at a total depth of $240.3 \mathrm{~m}$. The average recovery was an excellent $97.8 \%$. The drill string was recovered by $0008 \mathrm{hr}$. on 22 November.

Hole 586B cores were preserved uncut for the use of Leg 90 scientists. The admixture in the cores from Holes 586 and 586A of transported microfossil components dampened the interest of many of the Leg 89 scientists in using this site for detailed stratigraphy.

Hole $586 \mathrm{C}$ was spudded at $0541 \mathrm{hr}$. with a used bit and a hydraulic bit release in the bottom-hole assembly. More than $600 \mathrm{~m}$ of Neogene ooze and chalk were drilled nearly as fast as the pipe could be added to the string. The "wash" core barrel was retrieved with virtually nothing in it, and the only core from Hole $586 \mathrm{C}, 9.6 \mathrm{~m}$ long, with only $23 \%$ recovery, ended at $623.1 \mathrm{~m}$ total depth. In preparation for logging, the bit was released, and a slurry of fresh water and bentonite mud was pumped into the hole to displace the seawater. The drill string was pulled up close to the seafloor and the derrick was rigged for logging.

Three logging runs were made with the Schlumberger equipment. The logs appear to be excellent. The first run included measurements of sonic velocity, electrical spontaneous potential, electrical induction-spherically focused log, natural gamma radiation, and hole diameter by caliper. Then a second sonde replaced the first one. The other two runs were with that second sonde, but the final log was through a shorter interval and the sonde was pulled up the bore more rapidly. That sonde included measurements of formation density (compensated) and neutron porosity, along with a repeat of the gamma ray and caliper measurements.

All three gamma radiation logs showed, through the drill pipe, the increase above sediment background from ${ }^{234} \mathrm{U}$ and other short-lived isotopes immediately below the seafloor, and then a sharp drop in radiation as the tool was pulled up into seawater. The seafloor in 586C was at about $2218 \mathrm{~m}$. In retrospect, it seems that the filling of Core 586B-1, the gamma ray logs, and the PDR depths were correctly identifying the seafloor at about 2217 or $2218 \mathrm{~m}$ from the drill floor (2207 or $2208 \mathrm{~m}$ from sea level), and that the $2223.1 \mathrm{~m}$ ( $2213 \mathrm{~m}$ from sea level) determination from Core 586-1 may have resulted from some fluke, such as partial loss of the core through a faulty core catcher, or spudding into a depression of the seafloor. A depth of $2218 \mathrm{~m}$ has been used for all holes.

After the logging was completed and its rigging removed, the drill string was retrieved and the ship made ready for sea. The ship got under way at $0810 \mathrm{hr}$. on 23 November, moving northward while streaming the geophysical gear. The Glomar Challenger then passed over the beacon, taking water gun records (Fig. 2). Three attempts to obtain ASPER records failed, because of sonobuoys that did not work. They had been stored for about $4 \mathrm{yr}$. in part of the ship's hold without temperature control; probably their batteries had died months before.

For the next several hours as the vessel crossed the Ontong-Java Plateau, the reflection profiles (e.g., Figs. $3,4)$ showed some of the numerous fault scarps that expose older sediment and probably account for some of the sediment reworked into the sediments of Site 586 . The vessel continued on a southward course toward the Solomon Islands and on to Noumea.

\section{LITHOLOGIC SUMMARY}

Site 586 is located on the Ontong-Java Plateau within 1 nautical mile northwest of DSDP Site 289 at a water depth of $2207 \mathrm{~m}$ from sea level. Hole 586 was cored continuously to a sub-bottom depth of $39.3 \mathrm{~m}$. Coring in Hole $586 \mathrm{~A}$ began at $39.3 \mathrm{~m}$ and continued to $300.2 \mathrm{~m}$. The sedimentary section from 0 to $240.3 \mathrm{~m}$ sub-bottom was collected again in 25 cores at Hole 586B. The lithostratigraphy of Hole $586 \mathrm{~B}$ is described in a separate section by the Leg 90 scientists. A fourth hole, Hole 586C, was rotary-drilled for logging to a total depth of $623.1 \mathrm{~m}$ sub-bottom. The sediments recovered from Holes 586, $586 \mathrm{~A}$, and $586 \mathrm{C}$ comprise a single lithologic unit that consists of pale green to white foraminifer-nannofossil ooze and foraminifer-bearing nannofossil ooze and minor chalk of early Miocene to Recent age.

\section{Holes 586 and 586A}

The Pleistocene to Recent part of the sedimentary sequence recovered at Site 586 (Cores 586-1 through 586-5) is $39 \mathrm{~m}$ thick and contains higher concentrations of foraminifers than the rest of the sequence. These foraminifer-rich sediments contain more than $20 \%$ and up to $60 \%$ foraminifers (Figs. 5 and 6) and are classified as foraminifer-nannofossil and nannofossil-foraminifer ooze. 


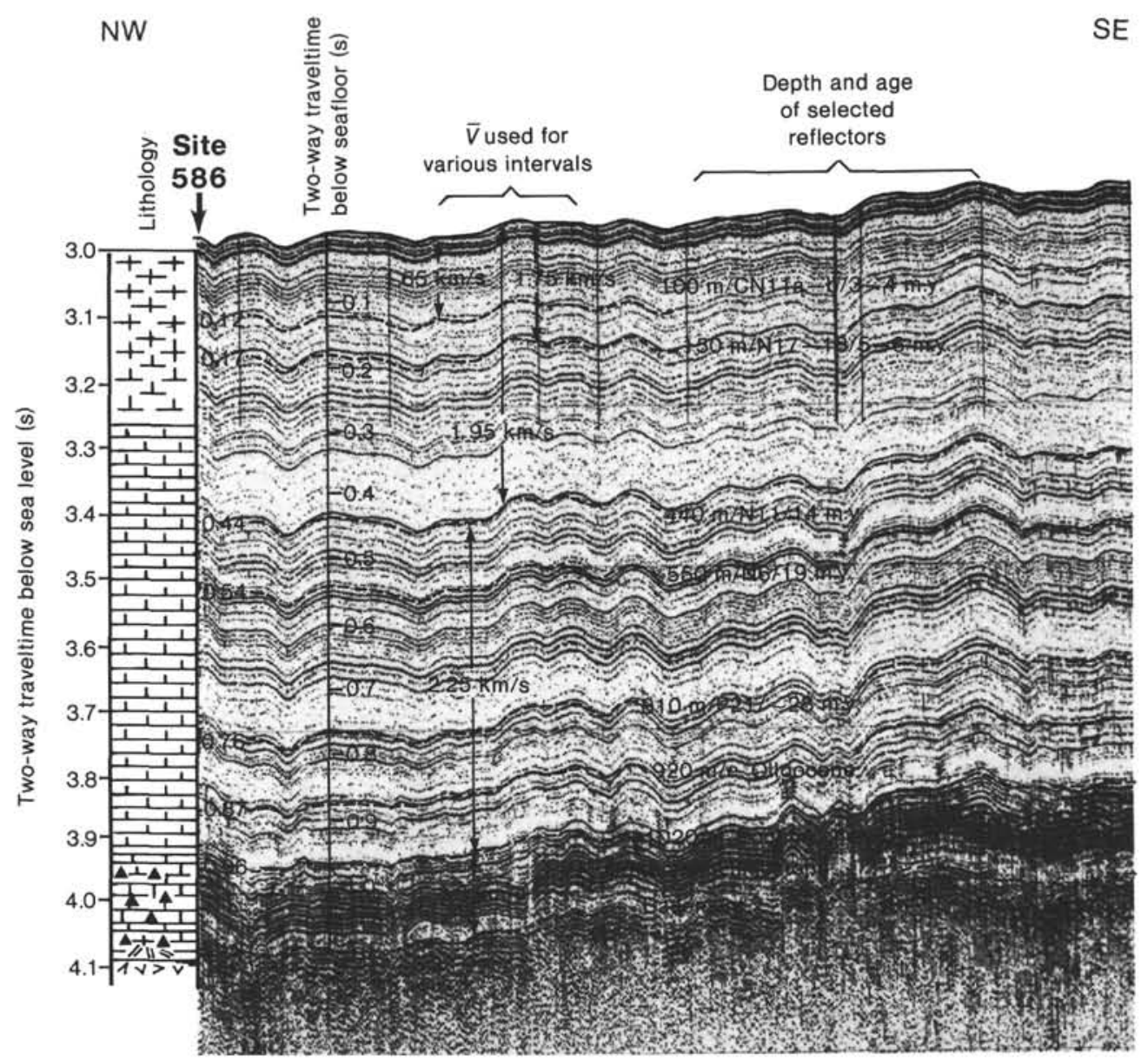

Figure 3. Interpretation of seismic reflection profile at Site 586, northeastern Ontong-Java Plateau. See text for explanation. Source, 80 in. $^{3}$ water gun, $40-160 \mathrm{~Hz}$ filter.

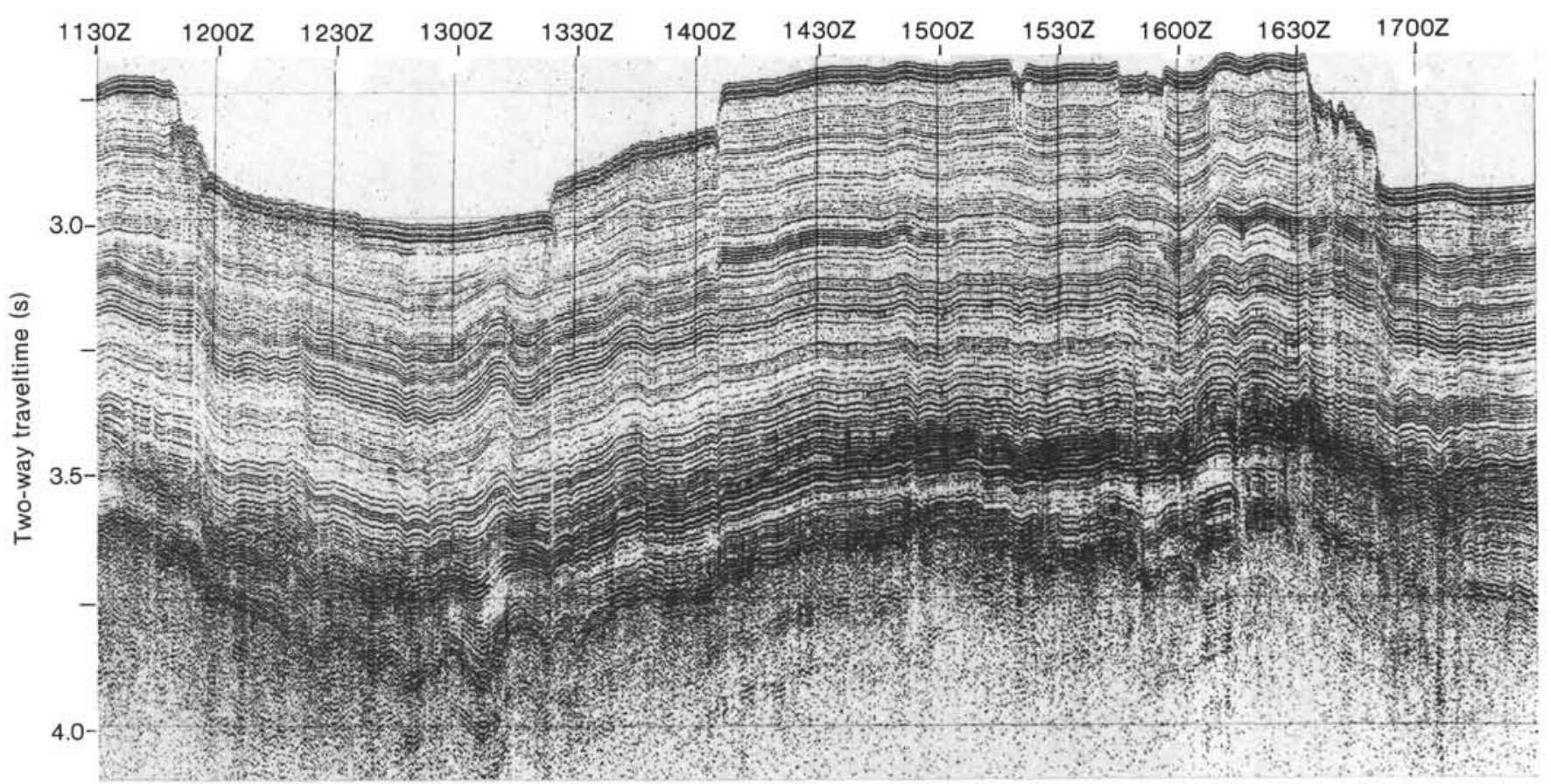

Figure 4. Fault-scarp topography shown by seismic reflection profile near Site 586. Local elevations and slopes such as these may have provided the sediment mixed with the autochthonous sediment at Site 586. 


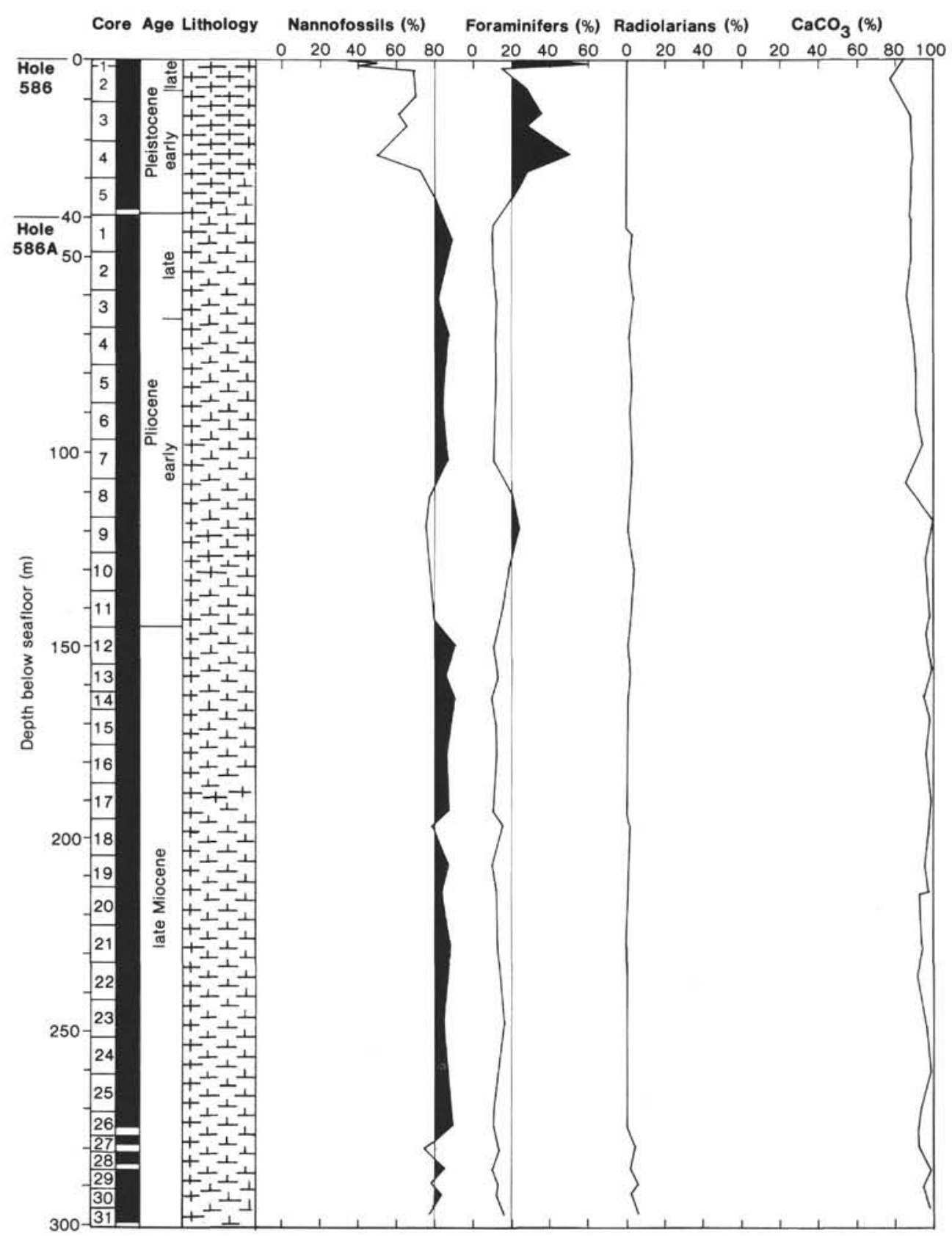

Figure 5. Summary lithology column.

Texturally they are silty clay and sandy silty clay. Sediments recovered in Hole 586A (upper Miocene through Pliocene; $39-300 \mathrm{~m}$ sub-bottom) are composed of more than $80 \%$ nannofossils and less than $20 \%$ foraminifers, and are classified as foraminifer-bearing nannofossil ooze. Results of analyses of 38 samples for $\mathrm{CaCO}_{3}$ range from 78 to $99 \%$ and average $93 \%$ (Table 2; Fig. 5). All other components in the sediments are minor (Fig. 6). Siliceous biogenic components, mainly radiolarians and diatoms, are present in minor amounts (up to several percent) throughout the section. They increase in abundance at the base of the recovered section (Figs. 5 and 6), but the total of siliceous biogenic components rarely exceeds $5 \%$. Texturally, all of the upper Miocene to Pliocene sediments are clay or silty clay.
As a result of compaction, the ooze generally does become somewhat stiffer with depth, and nodules of chalk occur within stiff ooze in Cores 586A-25 through 586A-31. Soft, soupy ooze does occur, however, even between some of the chalk nodules in the lower part of Hole 586A. The single core recovered from the base of Hole 586C (613.5-623.1 m, lower Miocene) also consists of interbedded foraminifer-bearing nannofossil chalk and stiff ooze, although some of the ooze is still soft and soupy. The chalk undoubtedly occurs as continuous layers, and its appearance in the cores as nodules is a result of breaking and rounding of the harder chalk layers by the drilling process. There does not appear to be any systematic pattern to the occurrence of the chalk nodules (layers), although chalk nodules in Section 586A- 
Dominant lithology

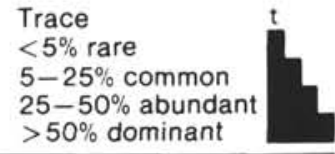

\begin{tabular}{|c|c|c|c|c|c|c|c|c|c|c|c|c|c|c|c|c|c|c|c|c|c|c|c|c|c|c|}
\hline \multirow[b]{2}{*}{ 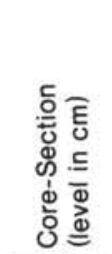 } & \multicolumn{7}{|c|}{ Biogenic components } & \multicolumn{9}{|c|}{ Nonbiogenic components } & \multicolumn{10}{|c|}{ Authigenic components } \\
\hline & 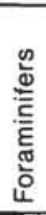 & 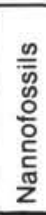 & 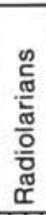 & $\begin{array}{l}\text { है } \\
\text { है } \\
\text { 임 }\end{array}$ & 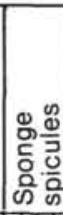 & 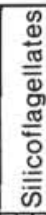 & $\begin{array}{l}\frac{0}{2} \\
\frac{0}{0} \\
\frac{5}{0} \\
\frac{5}{5} \\
\text { in }\end{array}$ & $\begin{array}{l}\text { No } \\
\text { đI } \\
\text { O }\end{array}$ & 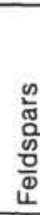 & 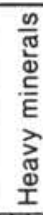 & 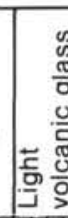 & 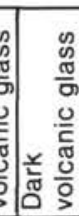 & 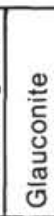 & & 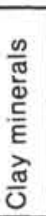 & $\stackrel{8}{\Sigma}$ & & 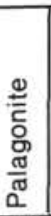 & 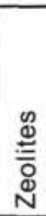 & 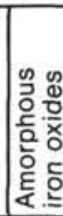 & 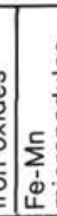 & 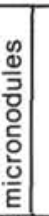 & $\underset{0}{\stackrel{0}{2}}$ & 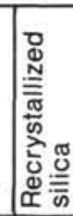 & 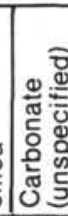 & 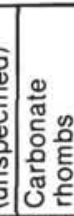 \\
\hline $1-1,79$ & & & $|t|$ & $\mid t$ & Tा & & & & & & & & & & & $|t|$ & & & & & & & & & & \\
\hline $2-2,98$ & & & $t$ & & $t$ & & & & & & & & & & & & & & & & & & & & & \\
\hline $2-6,116$ & & & & & & & & & & & $\mid t$ & & & & & $\mid t$ & & & & & & & & & & \\
\hline $3-1,122$ & & & & $t$ & & & & & & & & & & & & $t$ & & & & & & & & & & \\
\hline $4-1,56$ & & & & t & & & & & & & & & & & & $t$ & & & & & & & & & & \\
\hline $5-1,127$ & & & $t$ & & $t$ & & & & & & & & & & & & & & & & & & & & & \\
\hline $6-2,31$ & & & $t$ & & $t$ & & & & & & & & & & & & & & & & & & & & & \\
\hline $6-5,115$ & & & $t$ & & & & & & & & & & & & & & & & & & & & & & & \\
\hline $6-6,91$ & & & $t$ & & $t$ & & & & & & & & & & & & & & & & & & & & & \\
\hline $7-1,29$ & & & & & & & & & & & & & & & & & & & & & & & $t$ & & & \\
\hline $8-4,59$ & & & & & $t$ & & & & & & $t$ & & & & & 1 & & & & & & & $t$ & & & \\
\hline $11-1,28$ & & & & & & & & & & & & & & & & $t$ & & & & & & & $t$ & & & \\
\hline $11-4,55$ & & & & & & & & & & & & & & & & & & & & & & & & & & \\
\hline $12-3,80$ & & & & & & & & & & $\mid t$ & & & & & & & & & & & & & & & & \\
\hline $12-7,14$ & & & $t$ & & & & & & & & & & & & & & & & & & & & & & & \\
\hline $14-2,70$ & & & $t$ & & & & & & & & & & & & & & & & & & & & & & & \\
\hline $14-5,17$ & & & $t$ & & & & & & & & & & & & & & & & & & & & & & & \\
\hline $15-2,110$ & & & $t$ & & & & & & & & & & & & & & & & & & & & T & & & \\
\hline $16-6,62$ & & & $t$ & & $t$ & & & & & & & & & & & & & & & & & & $t$ & & & \\
\hline $17-1,45$ & & & & & $t$ & & & & & $t$ & & & & & & & & & & & & & & & & \\
\hline $17-2,45$ & & & & & & & & & & & & & & & & & & & & & & & & & & \\
\hline $17-3,45$ & & & $t$ & & & & & & & & & & & & & & & & & & & & & & & \\
\hline $17-4,45$ & & & $t$ & & $t$ & & & & & & & & & & & & & & & & & & & & & \\
\hline $18-1,35$ & & & t & & & & & & & & & & & & & & & & & & & & & & & \\
\hline $18-6,74$ & & & $\mathrm{t}$ & & $t$ & & & & & & & & & & & & & & & & & & & & & \\
\hline $19-1,29$ & & & & & & & & & & & & & & & & & & & & & & & $t$ & & & \\
\hline $19-1,65$ & & & & & $t$ & & & & & & & & & & & & & & & & & & & & & \\
\hline $19-5,118$ & & & 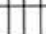 & & & & & & & & $t$ & & & & & & & & & & & & & & & \\
\hline $19-7,13$ & & & & & & & & & & & & & & & & & & & & & & & & & & \\
\hline
\end{tabular}

Minor lithology

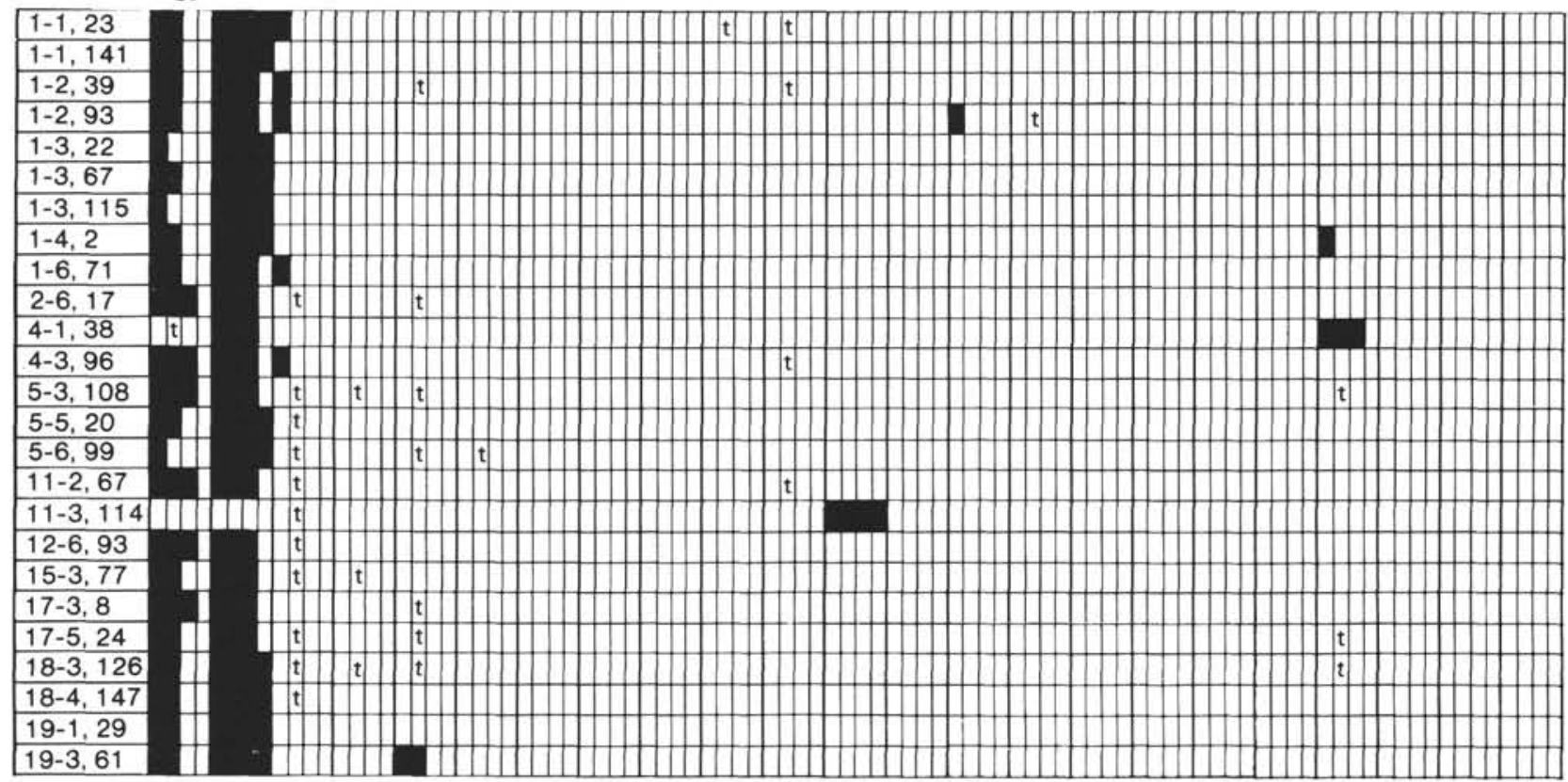

Figure 6. Smear slide summary, Hole 586B. 
Table 2. Carbonate bomb results, Holes 586 and 586A.

\begin{tabular}{|c|c|c|c|}
\hline $\begin{array}{c}\text { Core-Section } \\
\text { (interval in cm) }\end{array}$ & $\begin{array}{l}\text { Sub-bottom } \\
\text { depth }^{\mathrm{a}} \\
\text { (m) }\end{array}$ & $\% \mathrm{CaCO}_{3}$ & Lithology \\
\hline \multicolumn{4}{|l|}{ Hole 586} \\
\hline $1-1,31-32$ & 5.89 & 84 & \multirow[t]{2}{*}{ Nannofossil-foraminifer ooze } \\
\hline $2-3,110-111$ & 10.50 & 78 & \\
\hline $3-3,76-77$ & 19.66 & 88 & \multirow[t]{3}{*}{ Foraminifer-nannofossil ooze } \\
\hline $4-4,92-94$ & 30.82 & 89 & \\
\hline $5-2,105-106$ & 37.45 & 89 & \\
\hline \multicolumn{4}{|l|}{ Hole 586A } \\
\hline $1-2,79-80$ & 45.69 & 88 & \multirow{28}{*}{ Foraminifer-nannofossil ooze } \\
\hline $2-1,75-76$ & 54.75 & 88 & \\
\hline $2-3,70-71$ & 56.70 & 88 & \\
\hline $3-2,69-70$ & 65.79 & 86 & \\
\hline $4-2,48-49$ & 75.18 & 89 & \\
\hline $5-2,75-76$ & 85.05 & 90 & \\
\hline $6-2,29-30$ & 94.19 & 90 & \\
\hline $7-2,35-36$ & 103.85 & 94 & \\
\hline $8-2,31-32$ & 113.41 & 85 & \\
\hline $9-2,27-28$ & 122.97 & 99 & \\
\hline $10-2,30-32$ & 132.60 & 95 & \\
\hline $11-5,100-101$ & 147.40 & 97 & \\
\hline $12-2,64-65$ & 152.14 & 96 & \\
\hline $13-2,60-61$ & 161.70 & 99 & \\
\hline $14-2,24-25$ & 168.64 & 95 & \\
\hline $15-2,60-61$ & 173.90 & 98 & \\
\hline $16-2,70-71$ & 183.00 & 96 & \\
\hline $17-6,70-71$ & 198.60 & 99 & \\
\hline $18-2,60-61$ & 202.10 & 99 & \\
\hline $19-3,49-50$ & 213.09 & 96 & \\
\hline $20-2,20-21$ & 219.80 & 98 & \\
\hline $20-2,82-83$ & 220.42 & 93 & \\
\hline $21-4,108-109$ & 233.28 & 95 & \\
\hline $22-3,60-61$ & 240.90 & 92 & \\
\hline $23-5,82-83$ & 253.72 & 97 & \\
\hline $24-6,145-146$ & 265.45 & 99 & \\
\hline $25-6,137-138$ & 274.97 & 94 & \\
\hline $26-3,75-76$ & 279.45 & 93 & \\
\hline $27-2,105-106$ & 284.25 & 93 & \multirow{2}{*}{$\begin{array}{l}\text { Foraminifer-bearing nanno- } \\
\text { fossil soft ooze and chalk }\end{array}$} \\
\hline $28-4,45-46$ & 290.85 & 99 & \\
\hline $29-3,99-100$ & 294.49 & 96 & \multirow{3}{*}{$\begin{array}{l}\text { Foraminifer-bearing nanno- } \\
\text { fossil ooze and chalk }\end{array}$} \\
\hline $30-1,54-55$ & 295.84 & 96 & \\
\hline $31-1,121-122$ & 301.51 & 98 & \\
\hline
\end{tabular}

a Sub-bottom depths reflect original shipboard calculations and may be in error by $5.1 \mathrm{~m}$.

\section{7-3 seem to occur with a rhythmic spacing of 15 to} $20 \mathrm{~cm}$.

The top $15 \mathrm{~cm}$ of sediment in Hole 586 has been oxidized to pale brown (5Y 8/1), and probably represents the depth of burrowing, but the rest of the sediments are reduced and have the general overall appearance of very pale green. Sediment colors from the Munsell color chart are white (N9 and 5Y 8/1), bluish white (5B 9/1), pale greenish yellow (5Y 7/3), light greenish gray (5GY $8 / 1)$, and various other subtle tints of pale green. Thin layers (mostly less than $1 \mathrm{~cm}$ ) of slightly darker pale green, pale yellow, and light to medium gray are common above 135 and below $280 \mathrm{~m}$, but mostly these slightly darker colors occur as mottles in highly bioturbated pale green ooze. Many of these darker layers feel somewhat coarser in texture, but textural differences usually cannot be resolved in smear slides. The gray color of some layers and burrow mottles apparently is due to the presence of pyrite, which occurs as small spherical framboids. Compositional differences between the slightly darker green and yellow layers and mottles and the dominant pale green ooze could not be resolved by smear slides, al- though some qualitative observations suggest that the darker materials may contain slightly higher concentrations of altered volcanic glass and, as mentioned earlier, they tend to be somewhat coarser. In addition to the overall pale green color of the sediment and presence of pyrite, the reduced nature of the sediment is indicated by the odor of $\mathrm{H}_{2} \mathrm{~S}$ emitted when the cores were opened.

\section{Hole 586B (by Leg 90 shipboard scientific party)}

The section at Hole 586B is from one lithostratigraphic unit composed of foraminifer-bearing ( 5 to $25 \%$ ) to foraminifer- ( 25 to $75 \%)$ nannofossil ooze (Fig. 6). The color of the major lithology varies from light gray $(5 \mathrm{Y}$ $7 / 1)$ to light greenish gray (5GY 7/1) at the top, grading to very light gray (N8) to white (N9) at the bottom of the section. The recovered section is soft, grading to firm at about $100 \mathrm{~m}$ sub-bottom, but it is never firm enough to be classified as a chalk. In general, the sequence is intensely bioturbated. There are several sedimentary features related to the bioturbation including thin burrows (about $0.1 \mathrm{~cm}$ thick), larger mottles (about $0.5 \mathrm{~cm}$ diameter), and thin, but often very large-diameter $(1-20 \mathrm{~cm})$ burrow rinds of light gray (N5 to N7) color. The latter resemble Liesegang rings and probably result from the precipitation of iron sulfide minerals around preferred sites of sulfate reduction such as burrows rich in organic matter. Many of the burrows and other mottles also show color differences from the major lithology and tend toward yellowish grays $(5 \mathrm{Y} 8 / 1)$. Blebs of fine-grained iron sulfide (?pyrite) are common throughout the entire section. Very subtle laminations less than $2 \mathrm{~cm}$ thick occur throughout the sequence, but in smear slides the lithologies of the laminae appear identical to the surrounding ooze. Numerous thin zones of foraminifer-rich facies were found in the top $45 \mathrm{~m}$, apparently the results of current winnowing. Light greenish gray laminae $(5 \mathrm{GY} 7 / 1)$ are common, especially in the top $100 \mathrm{~m}$ of the sequence. The greenish color of these laminae is due to disseminated authigenic minerals, among which glauconite was identified as neoformed fillings of foraminifer tests in the lowest core sections and (possibly) celadonite resulting from the diagenetic alteration of volcanic glass in the upper core sections, where trace amounts of volcanic glass also occur.

Severe coring disturbance occurs in Section 586B-3-4 through 586B-3,CC, Section 586B-7-3 through 586B$7, \mathrm{CC}$, Cores 9 and 10, and Section 586B-13-1 through $586 \mathrm{~B}-13-3,100 \mathrm{~cm}$.

A comparison of Hole 586B with the shipboard descriptions of Hole $586 \mathrm{~A}$ shows only minor differences, except for the absence of a near-surface oxidized layer at Hole 586B. Hole 586B did not reach the depth of the chalk nodules found in Hole 586A.

\section{BIOSTRATIGRAPHY}

\section{Summary}

\section{Holes 586 and 586A}

The almost $300 \mathrm{~m}$ of sediments recovered in Holes 586 and $586 \mathrm{~A}$ span the time interval from Recent through 
almost all of the late Miocene. The three major planktonic groups are well represented throughout and display a moderate to good state of preservation.

As shown by the foraminifer record, the sediments, which at first sight appear to display the sedimentological characteristics of a foraminifer-nannofossil ooze, were affected by mechanical transport, that caused (1) an accumulation of foraminifer tests within the range of the sand fraction and (2) an admixture of forms from different environments, ranging from shallow-water platforms to bathyal depths. Thus, the sediments encountered at this site are transported and are more properly defined as a graded foraminifer-nannofossil silty sand. Evidence of such transport is also shown by the radiolarian assemblages, which display a large variation in the size distribution of the microfauna.

In spite of these sedimentological characteristics, the sedimentary succession appears to be almost continuous, as revealed by the biostratigraphic record. A synthesis of the biostratigraphic succession based on the three fossil groups is shown in Figure 7, where the major events within the foraminifer faunas are also plotted against absolute ages. Some minor reworking of older nannofossils and radiolarians was detected in the upper half of the sequence.

The major biostratigraphic events from the three groups correlate well except for the interval from Cores 586A-3 to 586A-5. There, a major discrepancy concerns the location of the boundary between the early and late Pliocene according to the planktonic foraminifers and calcareous nannofossils. Following the planktonic foraminifers the early/late Pliocene boundary is equated by definition to the last appearance datum (LAD) of Globorotalia margaritae, which in Hole 586A occurs between the core-catcher samples of Cores 3 and 4. According to the nannofossils, the same boundary should occur between Zone CN11b and Zone CN12a, which occurs in Core 586A-5 between Sections 4 and 6. Further studies will clarify if such a discrepancy (1) is due to reworking of planktonic foraminifers in higher levels, (2) is related to an erroneous correlation between the two zonal schemes, or (3) is due to the erroneous positioning of the early/late Pliocene boundary with respect to the nannofossil zonal scheme by the nannofossil specialists. The same succession of biostratigraphic events among the planktonic foraminifers, such as the LAD of Dentoglobigerina altispira and the first appearance datum (FAD) of Globigerinoides fistulosus and of Globorotalia tosaensis, was described in the same order by Srinivasan and Kennett (1981) from Site 289 and by Vincent (1981) from Site 463. In addition, they occur within the same nannofossil biozone at the three sites. The third hypothesis of a mislocation of the early/late Pliocene boundary with respect to the nannofossil zonation becomes a real possibility.

\section{Hole 586C}

The only core from Hole $586 \mathrm{C}$ yielded very well preserved and abundant radiolarian faunas, whereas planktonic foraminifers and calcareous nannofossils are very poorly preserved. All the three fossil groups speak for an early Miocene age. The zonal assemblages in the three groups, however, are not coeval. The possible interpretation is that the planktonic foraminifers are reworked, whereas the nannofossil assemblages are mixed with downhole contaminants. Thus the age based on the radiolarians is retained as the only valid one.

\section{Foraminifers}

\section{Holes 586 and $\mathbf{5 8 6 A}$}

Planktonic foraminifers are abundant in the sediments recovered from Holes 586 and 586A. The washed residues obtained from the core-catcher samples, however, show clear evidence of mechanical transport in the accumulation of foraminifer tests $>250 \mu \mathrm{m}$, whereas the fraction $<250 \mu \mathrm{m}$ contains a large amount of test fragments, sometimes up to $50 \%$ of the total fraction. Moreover, the amount of residue for the $250-150-\mu \mathrm{m}$ and $150-45-\mu \mathrm{m}$ fractions is one-half or one-third of the amount obtained from a typical pure nannofossil-foraminifer ooze. Thus, the sediments recovered at Site 586 might better be defined as a planktonic foraminifer silty sand.

Both planktonic and benthic foraminifers from the same sample show different preservation, the same species occurring with transparent and chalk tests. It is not clear if the best preserved tests indicate that the specimens are autochthonous or allochthonous.

In addition, each residue contains few to several specimens of Quinqueloculina, coarse agglutinated foraminifers, large nodosariids (one chamber was over $2 \mathrm{~mm}$ in size), and highly ornamented ostracodes indicative of an environment much shallower than the present water depth at Site 586 (2208 m below sea level) or than the estimated bathyal paleodepth based on the supposed autochthonous benthic foraminifers. It is worth mentioning that evidence of obvious reworking among planktonic foraminifers could not be detected in this preliminary study, although it cannot be ruled out. In spite of the mechanical transport and mixing of material from shallower depths, the biostratigraphic signal appears to be undisturbed.

The uppermost $39.3 \mathrm{~m}$ of the sequence was recovered in Cores 586-1 to 586-5. Below the mud line, the $1 \mathrm{~m}$ of Holocene sediments in Core 586-1 yielded a very rich planktonic assemblage. Abundant species include Globigerina rubescens (red), Globigerinoides ruber (red), $G$. mitra (red), G. sacculifer, Globorotalia tumida, Pulleniatina finalis, and Neogloboquadrina dutertrei. Traces of sulfur, pyrite, and organic matter partially coat or fill the planktonic foraminifer tests. The core-catcher sample of Core 586-1 belongs to the late Pleistocene Zone N23. The planktonic foraminifer assemblage consists of G. truncatulinoides, G. crassaformis, G. crassula, and Globigerinoides conglobatus, beside the species mentioned above. The tests of Globigerina rubescens and Globigerinoides ruber are still red in color.

From Core 586-2 to Section 586-5-6 planktonic foraminifer assemblages are early Pleistocene in age (Zone N22). Common to abundant species are Globorotalia tumida and G. tumida flexuosa, G. truncatulinoides, Pul- 


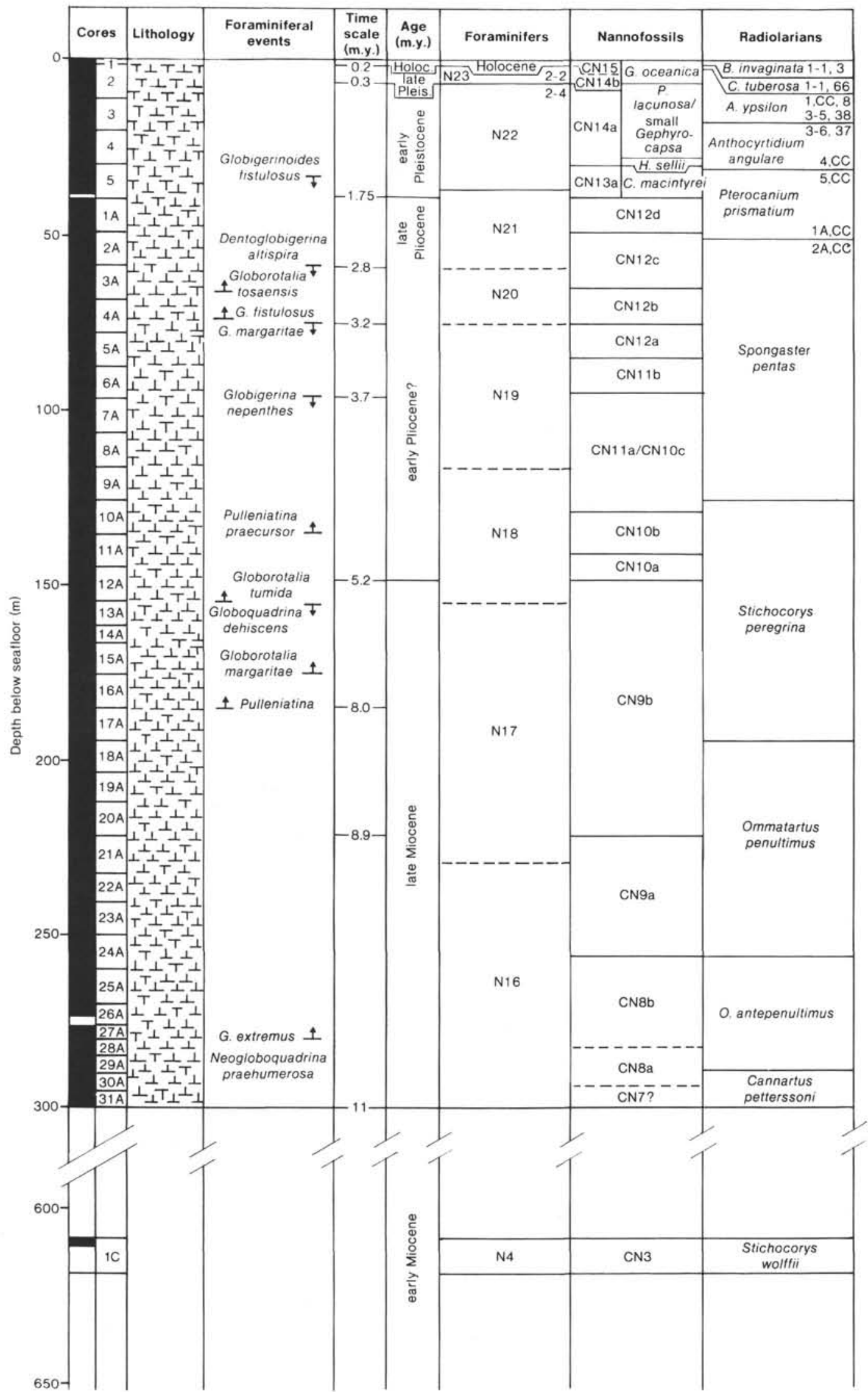

Figure 7. Biostratigraphy of Holes 586 and 586A plotted against lithology and planktonic foraminifer biostratigraphic events calibrated to the absolute ages. Core recovery in black. A after core number indicates Hole 586A Cores. 
leniatina obliquiloculata, Globigerinoides ruber (white), and $G$. sacculifer, among others. Few specimens of Globorotalia tosaensis and Globigerinoides aff. fistulosus and the unusual abundance of Streptochilus tokelauae in Sample 586-4,CC indicate early Zone N22. The late Pleistocene planktonic assemblage of Zone N21 occurs in core-catcher Sample 586-5, CC (the last core in Hole 586 ) and in Cores 586A-1 and 586A-2, where coring started at the same level at which Hole 586 was discontinued. This zonal assemblage is characterized by the occurrence of Pulleniatina obliquiloculata, Globorotalia tosaensis, T. tenuitheca, G. crassaformis, and by common to abundant Globigerinoides fistulosus and Streptochilus tokelauae. Accompanying species are Globorotalia tumida, G. tumida flexuosa, G. exilis, G. ungulata, sphaeroidinellids, Globigerinoides ruber, and rare G. extremus.

The core-catcher sample of Core 586A-3 yielded a planktonic foraminifer assemblage similar to those occurring in the overlying Cores 586A-1 and 586A-2 except for the occurrence of common, well-developed specimens of Dentoglobigerina altispira. According to Blow (1969) the latter taxon should not co-occur with Globorotalia tosaensis and $G$. tenuitheca, which are also present in Core 586A-3,CC. Further studies will clarify if the range of $D$. altispira in fact overlaps with that of $G$. tosaensis and $G$. tenuitheca or the occurrence of D. altispira in Core 586A-3,CC is anomalous and due to reworking. For the time being, Core 3 is attributed to Zone N20, the oldest zone in the late Pliocene.

The interval from Cores $586 \mathrm{~A}-4$ to $586 \mathrm{~A}-8$ is attributed to the early Pliocene Zone N19 on the basis of the occurrence of Globorotalia margaritae with Pulleniatina obliquiloculata, Dentoglobigerina altispira, Globorotalia tumida, G. tumida flexuosa, Neogloboquadrina humerosa, and Globigerinoides extremus, and including Streptochilus tokelauae, which was limited to core 586A-4. The planktonic foraminifer assemblages in Cores 586A7 and 586A-8 are differentiated from those contained in Cores 4 to 6 by the occurrence of Globigerina nepenthes, Pulleniatina spectabilis, $P$. praecursor, and Streptochilus latum. Globorotalia margaritae is very rare in some samples. The boundary between Zones N19 and $\mathrm{N} 18$, still early Pliocene in age, is tentatively placed between Cores 586A-8 and 586A-9, based on a single specimen of Sphaeroidinella that occurs in Core 586A-8,CC. (Sphaeroidinellopsis and Sphaeroidinella are rare components of most of the assemblages recovered at Site 586.) The interval from cores 586A-9 through $586 \mathrm{~A}-12$ yielded a planktonic foraminifer fauna characteristic of Zone N18 of latest Miocene to early Pliocene age. The lower boundary of Zone N18 corresponds to the FAD of Globorotalia tumida in the evolutionary transition from G. plesiotumida, which occurs in Core 586A-12,CC. Two biostratigraphic events occur in this zone. The first is the FAD of Pulleniatina praecursor in Core 586A-10, an early Pliocene event, whereas the second event corresponds to the LAD of Globoquadrina dehiscens. The latter event is equated with the Miocene/Pliocene boundary (Berggren, 1977). Common species in Zone N18 are Neogloboquadrina humerosa, N. acostaensis, Globiger- ina nepenthes, Pulleniatina primalis, P. spectabilis, Globorotalia scitula, G. cultrata, Globigerinoides sacculifer, G. extremus, G. obliquus, D. altispira, G. baroemoenensis, and Streptochilus latum.

The interval from Cores 586A-13 to 586A-20 yielded a planktonic foraminifer assemblage characteristic of the late Miocene Zone N17, the lower boundary of which corresponds to the FAD of Globorotalia plesiotumida evolving from $G$. merotumida. The major biostratigraphic event within Zone N17 is the FAD of Pulleniatina s.1., which occurs in Core 586A-16. Rare specimens of Globorotalia margaritae are recorded from Core 586A-15 upward. Beside the events mentioned above, the assemblages of Zone N17 are similar to those of Zone N18.

The interval from Core 586A-21 to total depth (Core 586A-31) contains planktonic faunas attributable to the late Miocene Zone N16. Two major biostratigraphic events occur within this zone: the FAD of Neogloboquadrina humerosa, evolving from N. acostaensis, and of Globigerinoides extremus, that evolves from $G$. obliquus in Core 386A-27. Common species in this interval include the index species $N$. acostaensis and Globorotalia merotumida, Globigerina nepenthes, Globorotalia cultrata (which is very abundant in some samples), Globigerinoides obliquus, G. sacculifer, Dentoglobigerina altispira, G. baroemoenensis, G. dehiscens, and Streptochilus latum.

Globoquadrinids, Globorotalia lenguaensis, and $G$. praelenguaensis are particularly abundant in the two lowermost cores.

\section{Holes 586C}

Only one core was recovered from Hole $586 \mathrm{C}$ in addition to a washed core at the sub-bottom depth of $608 \mathrm{~m}$. Planktonic foraminifers are abundant but very poorly preserved. Rare Globigerinoides immaturus and common Globorotalia kugleri and G. pseudokugleri are associated with large globigerinids, primitive Dentoglobigerina altispira, Globoquadrina praedehiscens, and very rare $G$. binaiensis. This assemblage is characteristic of the upper part of Zone N4, which is early Miocene in age. Reworked Oligocene faunas may be present.

\section{Nannofossils}

\section{Holes 586 and 586A}

Core-catcher samples from Holes 586 and 586A were examined to provide an outline of the nannofossil biostratigraphy. Smear slide preparations were made from intervals within cores when it was necessary to locate zonal boundaries and important datums. Nannofossils are abundant in every sample examined. A reduction in the nannofossil content was seen in samples from Core $586-4$, the top of Core 586A-2, and the base of Core $586 \mathrm{~A}-1$. The preservation of assemblages fluctuates between moderate and good, although there was an overall decrease in the quality of preservation downhole. This deterioration in preservation is represented as overgrowths on the discoasters in lowermost Pliocene and upper Miocene sediments. Discoasters in samples from Cores $586 \mathrm{~A}-12$ through $586 \mathrm{~A}-16$ are slightly to moderately over- 
grown and those in sediments below these cores are moderately to heavily overgrown. Heavy overgrowths on certain species in Cores 586A-25 through 586A-31 made identification of these forms difficult. Placoliths are well preserved throughout and are only slightly etched in samples where the discoasters are overgrown. Sample 586A$28-4,36-37 \mathrm{~cm}$, in which there are over $10 \%$ diatoms, contains a well-preserved assemblage with little overgrowth of the discoasters. Samples above and below this level contain less than $1 \%$ diatoms. Thus, the amount of noncalcareous constituents in these samples may influence the extent to which diagenesis may alter the nannofossil assemblages. Problems in identification caused by these overgrowths led to uncertainties in the biostratigraphy in the bottom of the hole, because many of the discoasters are utilized as datums in the late Miocene.

Figure 8 shows the nannofossil datums, along with the zonation schemes of Okada and Bukry (1890), Ellis (1982), Martini (1971), and Gartner (1977), graphed in relation to the cores recovered in Holes 586 and 586A. The section appears to be continuous, as all the nannofossil zones from the Discoaster hamatus Zone through the Emiliania huxleyi Zone are present. The only reworking detected was in Cores 586A-7 through 586A-9, where some late Miocene discoasters were reworked into Pliocene sediments. Some of the zonal boundaries in the biostratigraphic zonations mentioned above could not be accurately determined. The first occurrence of Emiliania huxleyi could extend much lower than indicated, because this species is best identified on the electron microscope. If so, it is possible that a hiatus may be present within the upper Pleistocene sediments in Cores 586-1 and 586-2. The first appearances of Gephyrocapsa caribbeanica and $G$. oceanica, which are used as successive datums in the early Pleistocene by Okada and Bukry (1980) and Ellis (1982), are synchronous in this section, and the G. caribbeanica Subzone (CN13b/WPN30b) could not be recognized. It is more likely that this is a problem inherent in these stratigraphies rather than an indication of a hiatus in this section (see Gartner, 1977). There is, however, the possibility that part of Core 1 was lost through the core catcher (see Operations section).

Amaurolithus tricorniculatus did not occur in any of the samples examined. Both Okada and Bukry (1980) and Martini (1971) use the last occurrence of this species in lower Pliocene sediments to define a zonal boundary, and so some resolution is lost when applying these zonations to this section. Ellis (1982) also found this to be true in sediments from the Mariana Trench and used the acme of Sphenolithus neoabies to resolve the boundary problem between the Sphenolithus neoabies Subzone and Ceratolithus rugosus Subzone. The extinction of $A$. primus is used in conjunction with that of $A$. tricorniculatus in the Okada and Bukry (1980) zonation to define this same boundary. This species is restricted to the Amaurolithus primus Subzone in these cores, except for Sample 586A-9-4, 36-37 cm, into which it is reworked with other late Miocene species. The last occurrence of this species in upper Miocene sediments at Sites 541 and 542 in the equatorial Atlantic is further evidence that this early Pliocene datum is not reliable.
Problems were also encountered in locating the lower boundary of the Discoaster quinqueramus Zone. It has been placed within core $586 \mathrm{~A}-24$ at the first occurrence of Discoaster berggrenii because all three zonal schemes recognize this datum. The first occurrence of $D$. surculus, which is used in addition to $D$. berggrenii by both Okada and Bukry (1980) and Ellis (1982), is first seen in core 586A-26. The rarity of this species in Cores 586A25 and 586A-26 and the overgrowths that obscure its bifurcate tips make this datum hard to locate. Ellis (1982) also recognized the extinction of $D$. bellus and $D$. neohamatus at this boundary. These two species, although rare, are found in Core 586A-23 above the first occurrence of $D$. berggrenii. The last common occurrence of $D$. bellus, however, is coincident to the entry of $D$. bergrenii.

A few specimens of $D$. hamatus (five rays) were found in Samples 586A-30,CC and 586A-31,CC, and these sediments are tentatively placed in the $D$. hamatus Zone. $D$. neohamatus is common in these samples, whereas $D$. bellus and $D$. pentaradiatus are rare. Ellis (1982) uses the first occurrence of $D$. pentaradiatus to mark the top of the D. hamatus Zone. Thus, it appears that the top of the D. hamatus Zone was reached in Core 586A-31, or it may be that these extremely rare specimens of $D$. hamatus are reworked. Species of the genus Catinaster, which are normally found in sediments of those ages, are not present.

\section{Radiolarians}

For Site 586 one sample per section was studied for the first four cores; only the core-catcher samples were examined from Cores $586-4$ to $586 \mathrm{~A}-31$ and $586 \mathrm{C}-1$.

For the biostratigraphic zonation we followed Nigrini (1971) for the Quaternary, and Riedel and Sanfilippo (1978) for the remainder of the Cenozoic. The use of the evolutionary transition from Lamprocyrtis neoheteroporos to $L$. nigrinae instead of the upper morphotypic limit of Pterocanium prismatium is adopted here for the definition of the upper limit of the Pterocanium prismatium Zone. This change greatly reduces the range of the $A n$ thocyrtidium angulare Zone. Because Spongaster berminghami is rare, we have adopted the first appearance of $P$. prismatium to define the base of the Spongaster pentas Zone. This datum is essentially synchronous with that of the standard zonation.

The preservation of the radiolarian fauna is moderate except for some levels where the specimens are broken (Cores 586-2, 586A-6, and 586A-13). The abundance of the fauna permits us to recognize three assemblages: (1) Core 586-1 with a common fauna; (2) Cores 586-2 to 586A-14 with a few to common fauna; (3) Cores 586A-15 to $586 \mathrm{~A}-31$ and $586 \mathrm{C}-1$ with a common to abundant fauna, often accompanied by diatoms.

The uppermost Quaternary radiolarian zone, Buccinosphaera invaginata, was identified in Sample 586-1-1, $2-3 \mathrm{~cm}$. Sample $586-1-1,66-67 \mathrm{~cm}$ is related to the $\mathrm{Col}$ losphaera tuberosa Zone. Amphirhopalum ypsilon Zone extends from Samples 586-1,CC to 586-3-5, 37-38 cm. Some reworked specimens from the lower Pleistocene occur in Core 586-3. The Anthocyrtidium angulare Zone 


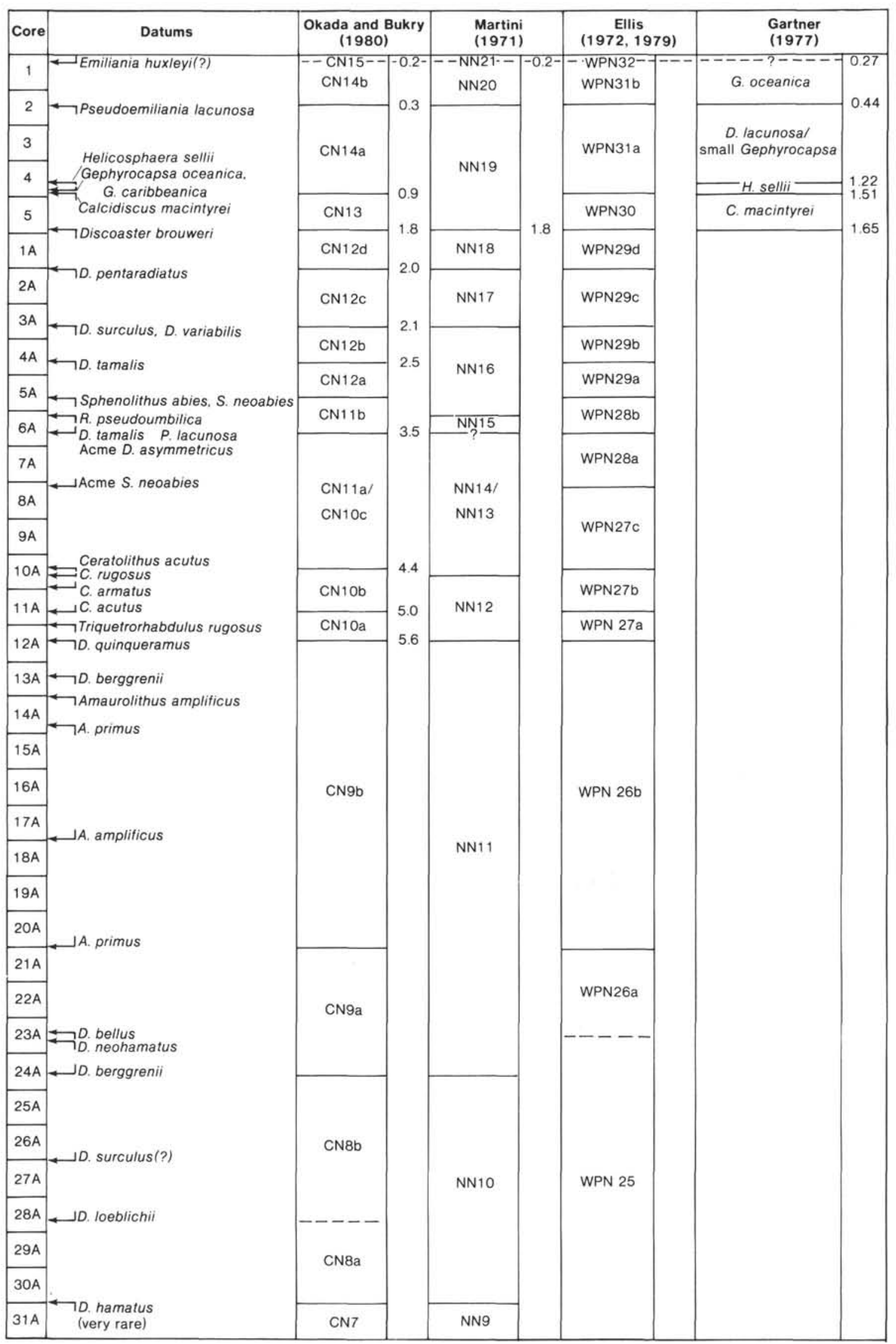

Figure 8. Nannofossil datums, Holes 586 and 586A. 
extends from Core 586-3-6, 36-37 cm to 586-4,CC; Pterocanium prismatium Zone from 586-5, CC to 586A-1,CC; Spongaster pentas Zone from 586A-2,CC to 586-9,CC; Stichocorys peregrina Zone from 586A-10,CC to 586A17,CC; Ommatartus penultimus Zone from 586A-18,CC to 586A-23,CC; $O$. antepenultimus Zone from 586A24,CC to 586A-29,CC; and the Cannartus petterssoni Zone was found below 586A-30,CC. Core 586C-1 is from the $S$. wolffii Zone.

There is a large variation in the size of the microfauna. The size fraction $>150 \mu \mathrm{m}$ is large in some samples and small in others. For example, in 586A-8,CC less than $1 \%$ of the assemblage is $>150 \mu \mathrm{m}$. A high percentage of small tests can be interpreted to result from an allochthonous, transported fauna; a high percentage of large tests indicates an autochthonous fauna.

\section{Summary, Hole 586B (completed by Leg 90 scientists)}

The $240.3 \mathrm{~m}$ of sediments recovered in Hole 586B were dated as Quaternary to late Miocene. Although only a limited number of samples were examined, there appears to be no evidence of any stratigraphic break. The following groups of fossils were recorded: planktonic and benthic foraminifers, calcareous nannofossils, diatoms, silicoflagellates, and radiolarians.

No evidence of reworking was found in the planktonic foraminifers and only one specimen of displaced Discoaster hamatus was found in Sample 586B-21,CC.

\section{Foraminifers, Hole 586B}

Planktonic foraminifers are both abundant and well preserved in samples from Cores 586B-2 through 586B-25. There is no evidence of reworking, which has been suggested for the faunas and floras of Holes 586 and 586A.

The Globorotalia truncatulinoides Zone $(=$ N22) yielded a rich fauna, as, for example, in Core 586B-2, which included the zone fossil and the following index taxa: Globorotalia menardii (sinistral) (=G. cultrata), Pulleniatina obliquiloculata (dextral), Sphaeroidinella dehiscens, Neogloboquadrina dutertrei (d), and Globigerinoides ruber.

In Cores 586B-5-1 through 586B-8-5, the Globigerinoides fistulosus Zone ( $=\mathrm{N} 21$ ) yielded the following index species: the zone fossil, Globorotalia tosaensis, $G$. tumida (s), S. dehiscens, P. obliquiloculata (d), and Globigerinoides extremus.

The Neogloboquadrina humerosa Zone $(=\mathrm{N} 19-\mathrm{N} 20)$ was found in Cores 586B-8-6 through 586B-13-7; important species include Globoquadrina altispira, Globorotalia tumida, P. primalis, P. spectabilis, Globigerinoides extremus, Globigerina decoraperta, and Neogloboquadrina humerosa. No. Globorotalia margaritae were found in the samples.

The Globorotalia tumida Zone (=N18) was found in Core 586B-17; a relatively low diversity fauna yielded the following diagnostic taxa: the zone fossil, $N$. acostaensis, G. juanai, and P. primalis (s).

The Pulleniatina primalis Zone ( $=\mathrm{N} 17 \mathrm{~b})$ was encountered in Sample 586B-17-6, with the following diagnostic species: the zone fossil, Globorotalia plesiotumida (d), Globoquadrina dehiscens, and Sphaeroidinellopsis paenedehiscens.
The Globorotalia plesiotumida Zone (=N17a) was recorded from Section 586B-21-5 through 586B-25-5 with the zone fossil, Globoquadrina dehiscens, N. acostaensis, and $S$. seminulina.

Benthic foraminifers were examined from ten samples through cores 5 and 6 ; each sample was taken from a different lithology or colored interval in the two cores. The foraminifers, generally accompanied by radiolarians, were highly fragmented in samples from the green, tan, olive, and gray white intervals, whether of coarser of finer texture. Only the gray, fine-grained layers contain little evidence of fragmentation. Typical species are Uvigerina auberiana, U. proboscidea, Nonion barleanum, N. pompiliodes, Pullenia bulloides, Eggerella bra$d y i$, and Pyrgo murrhina. Several broken specimens of Quinqueloculina were found only in the green layers, in which fragmentation is very intense. Other than the Quinqueloculina specimens, the benthic foraminifers appear to be in place.

\section{Calcareous Nannoplankton, Hole 586B}

Core-catcher samples and enough other samples accurately to determine zonal boundaries were examined for calcareous nannoplankton. Hole 586B ranges in age from late Pleistocene to late Miocene and includes all the calcareous nannoplankton zones (NN21 to NN11a).

\section{Pleistocene}

The occurrence of Emiliania huxleyi in Sample 586B-1, top, places this sample in the late Pleistocene Emiliania huxleyi Zone (NN21).

The late Pleistocene Gephyrocapsa oceanica Zone (NN20) occurs between the last occurrence of $E$. ovata in Sample 586B-1-5, 30-31 cm and the first occurrence of E. huxleyi and includes Samples 586B-1-3, 30-31 cm and 586B-1-4, 30-31 cm.

The presence of E. ovata and the absence of Calcidiscus macintyrei in Samples 586B-1-5, 30-31 cm to 586B-4-2, 30-31 cm place these samples in the upper subzone of the early Pleistocene Emiliania ovata Zone (NN19b). The lower subzone (NN19a) includes the interval from Samples 586B-4-3, 30-31 cm to 586B-5-2, 30-31 cm, above the last occurrence of Discoaster brouweri in Sample 586B-5-3, 30-31 cm.

\section{Pliocene}

The presence of Discoaster brouweri and the absence of D. pentaradiatus in Samples 586B-5-3, 30-31 cm to 586B-6-4, 30-31 cm places this interval in the late Pliocene Discoaster brouweri Zone (NN18). The presence of $D$. pentaradiatus and the absence $D$. surculus in Samples 586B-6-5, 30-31 cm and 586B-6-6, 30-31 cm places these samples in the late Pliocene $D$. pentaradiatus Zone (NN17). The interval from Sample 586B-6-7, 30-31 cm to 586B-8,CC, above the last occurrence of Reticulofenestra pseudoumbilica in Sample 586B-9,CC, is placed in the late Pliocene $D$. surculus Zone (NN16). The interval from Sample 586B-9, CC to 586B-13-7, 30-31 cm, above the last occurrence of Amaurolithus tricorniculatus in Sample 586B-13,CC, is placed in the early Pliocene Reticulofenestra pseudoumbilica Zone (NN15). The first occurrence of D. asymmetricus in Sample 586B-15-1, 
$30-31 \mathrm{~cm}$ places Samples 586B-13, CC to 586B-15-1, 30$31 \mathrm{~cm}$ in the early Pliocene $D$. asymmetricus Zone (NN14). The first occurrence of Ceratolithus rugosus in Sample 586B-15,CC places Samples 586B-15-2, 30-31 cm to $586 \mathrm{~B}-15, \mathrm{CC}$ in the early Pliocene Ceratolithus rugosus Zone (NN13). The interval from Samples 586B-16-1, $30-31 \mathrm{~cm}$ to $586 \mathrm{~B}-17, \mathrm{CC}$, above the last occurrence of D. quinqueramus in Sample $586 \mathrm{~B}-18-1,30-31 \mathrm{~cm}$, is placed in the early Pliocene Amaurolithus tricorniculatus Zone (NN12).

\section{Miocene}

The presence of Discoaster quinqueramus together with Amaurolithus primus in Samples 586B-18-1, 30-31 cm to $586 \mathrm{~B}-21-4,30-31 \mathrm{~cm}$ places this interval in the upper subzone of the late Miocene Discoaster quinqueramus Zone (NN11b). The absence of $A$. primus and the presence of $D$. quinqueramus in Samples 586B-21-5, 30-31 $\mathrm{cm}$ to $586 \mathrm{~B}-25, \mathrm{CC}$ places this interval in the lower subzone of the $D$. quinqueramus Zone (NN11a).

\section{Diatoms and Silicoflagellates, Hole 586B}

Diatoms were noted in low numbers in Samples 586B4, CC through 586B-8, CC, of late Pliocene-early Pleistocene age. Among them the large diatom Ethmodiscus rex is present in Samples 586B-5,CC and 586B-8,CC. Rare to few diatoms were found in the lower lower Pliocene Samples 586B-14,CC through 586B-16,CC, and in the upper Miocene Samples 586B-22,CC and 586B-25,CC. In Samples 586B-4,CC and 586B-6,CC rare silicoflagellates were encountered.

\section{Radiolarians, Hole 586B}

Radiolarian fragments were observed during smear slide analysis at various levels.

\section{SEDIMENTATION RATES}

Sedimentation rates for Holes 586 and 586A are shown in Figure 9. In Figure 10 sedimentation rates for Hole $586 \mathrm{C}$ are shown from $305 \mathrm{~m}$ sub-bottom to total depth of $623.1 \mathrm{~m}$. For the upper part, sedimentation rates are those from the previous holes, plotted at a different scale.

Accumulation rates vary consistently throughout the sequence drilled in the first two holes. The maximum rate occurred in the latest early Pliocene (from 3.7-3.2 m.y. ago) when sediments accumulated at a rate of about $54 \mathrm{~m} / \mathrm{m}$.y. A minimum rate of $13 \mathrm{~m} / \mathrm{m}$.y. occurred in the latest Miocene, between 8 and 5.2 m.y. ago.

In the younger part of the sequence sediments were deposited at rates ranging from 25 to $20 \mathrm{~m} / \mathrm{m}$.y. Rates of $\sim 37 \mathrm{~m} / \mathrm{m}$.y. were calculated for the remaining part of the early Pliocene and the early late Miocene.

The lower part of the sequence was deposited at an average rate of $\sim 39 \mathrm{~m} / \mathrm{m}$.y. (Fig. 10). Details cannot be determined because Hole $586 \mathrm{C}$ was washed nearly to its total depth.

\section{ORGANIC GEOCHEMISTRY}

The organic carbon contents were determined for two samples from Hole 586 and 14 samples from Hole 586A, covering the cored section down from 0 to $296 \mathrm{~m}$ below seafloor. For analytical details see the organic geochemistry section in the Site 585 summary chapter (Leg 89 Initial Report; Moberly, Schlanger, et al., in press). As obvious from the data summarized in Table 3, the organic carbon contents vary from $0.62 \%$ (based on dry sediment weight) to less than $0.01 \%$ (i.e., below detection limit). The higher values are found in the upper part of the section penetrated (mean value of $0.35 \%$ for Cores 586-1, 586-5, 586A-1 to 586A-8). An abrupt decrease in organic carbon contents occurs between Cores 586A-8 and 586A-9. From Core 586A-9 downward the values remain very low $(0.03 \%$ and less) throughout the hole to total depth. The elevated organic carbon contents in the uppermost $115 \mathrm{~m}$ of this drill site exceed the minimum threshold value commonly required for petroleum source rocks of the carbonate or evaporite facies $(0.3 \%)$. The organic carbon contents of these samples, however, should be verified by shore-based independent analyses. The discussion of analytical limitations of the $\mathrm{CHN}$-Analyzer and sample pretreatment procedures in the Organic Geochemistry section of the Site 585 summary chapter should be noted (Moberly, Schlanger, et al., in press).

The elevated organic carbon contents found from 0 to $115 \mathrm{~m}$ depth are associated with relatively lower $\mathrm{CaCO}_{3}$ contents of the sediments $(84-90 \%)$, as compared to Cores $586 \mathrm{~A}-9$ to $586 \mathrm{~A}-30$, where $\mathrm{CaCO}_{3}$ contents in excess of $93 \%$ (in some even $99 \%$ ) were measured.

\section{INORGANIC GEOCHEMISTRY}

Tables 4 and 5 and Figure 11 constitute this report; there is no text.

\section{PALEOMAGNETICS}

\section{Hole 586B (by Leg 90 shipboard scientific party)}

Holes 586 and 586A were subsampled for paleomagnetic analysis by Leg 89 personnel and have yet to be measured. NRM measurements have been made on two specimens per section from Hole 586B using a cryogenic magnetometer, with geometric mean intensity $=0.058$ $\mu \mathrm{G}$; scalar mean inclination $=-0.41 \pm 35.6^{\circ}$ s.d.; axial dipole inclination $=-1.0^{\circ}$; and mean angle between repeat measurement $=6.5^{\circ}$.

A zone of relatively strongly magnetized sediment ( 2.5 to $7.5 \mu \mathrm{G}$ ) occurs at the top of the sequence above 586B-1-6, $27 \mathrm{~cm}$ (7.77 m depth). Intensities drop rapidly to values of typically $0.05 \mu \mathrm{G}$ below the middle of Core 2. Fairly high intensity spikes are common, the most prominent being listed in Table 6 . These spikes are not associated with any obvious macroscopic changes in the sediment.

Below the high-intensity zone in Core 1 directions become highly scattered. Inclination data cannot be used to infer polarity as the site is too close to the equator. Unfortunately, there were no orientation data for these cores. The random scatter in inclinations indicates that the primary remanence signal was not being observed. Declinations can be used to infer the presence of only 


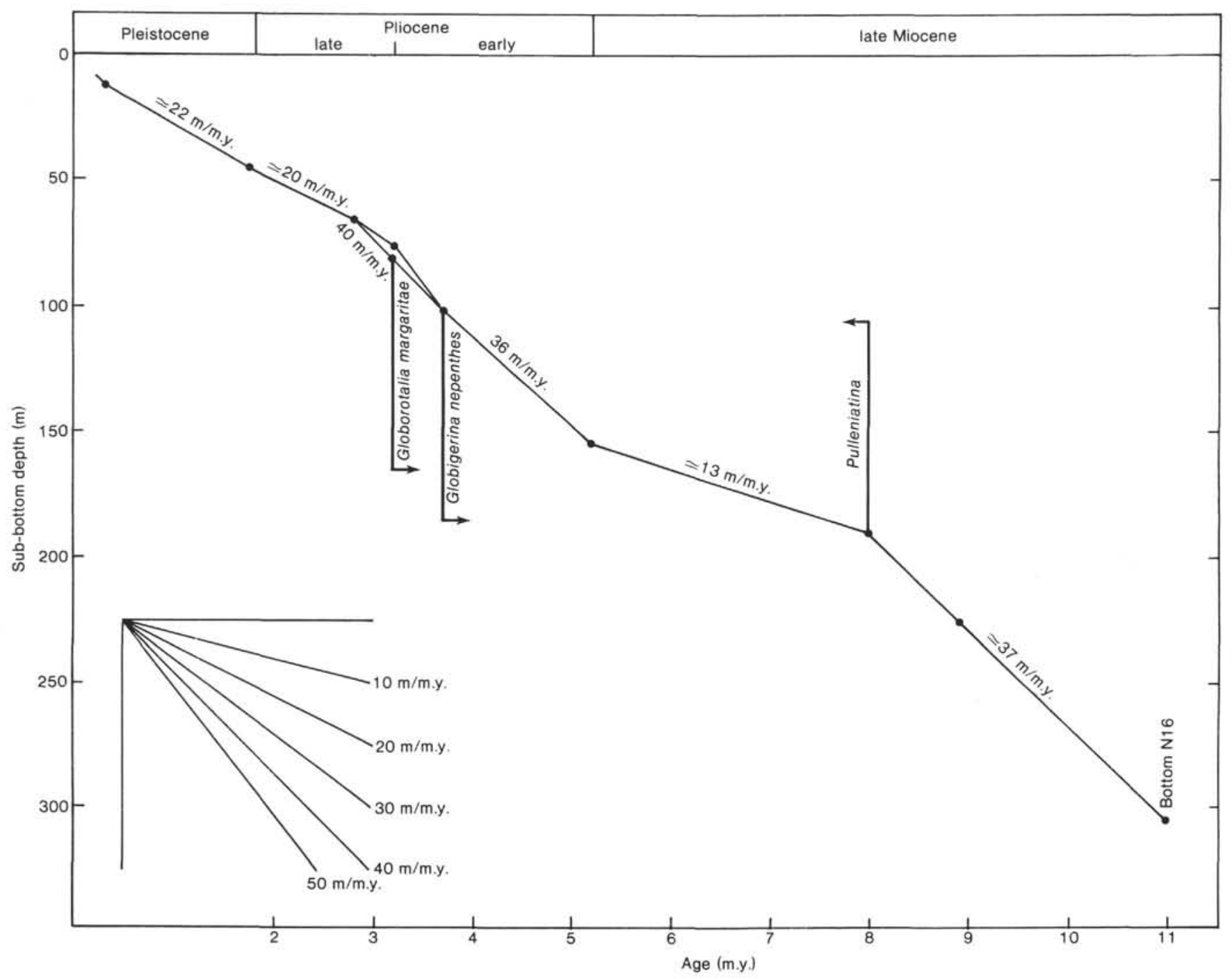

Figure 9. Sedimentation rates of Holes 586 and 586A. Data points according to planktonic foraminifers.

one polarity transition, the Brunhes/Matuyama boundary (0.73 m.y. ago) between Sections 586B-2-3 and 586B2-4 (12.85-15.10 m).

\section{PHYSICAL PROPERTIES}

Compressional wave velocity measurements $\left(V_{\mathrm{p}}\right)$ were made on whole core samples in the liner for every section from 586A-22-5 to 586A-31-3 and for one section of each core from 586B-1 to 586B-25, after the temperature of the cores equilibrated with that of the core lab. These measurements are of the horizontal (parallel to bedding) $V_{\mathrm{p}}$. Continuous GRAPE measurements were made on every other section of cores from Holes 586 and 586A, and on almost all sections from Hole 586B. Using samples taken with a minicore-sized metal cylinder, water content, porosity, and wet-bulk density were measured by means of the gravimetric method on one sample every other section in Hole 586A. All methods used in these measurements are described in Boyce (1976a).

All measured values except those of wet-bulk density by the continuous GRAPE are listed in Table 7. Values of wet-bulk density corresponding to the locations of velocity measurements are tentatively estimated from the hard-copy graphs of continuous GRAPE and used for the calculation of impedance. Figure 12 shows the variations of physical properties with depth for Site 586 .

As the sediment layer down to the depth of $300 \mathrm{~m}$ at Site 586 consists of a single lithologic unit of foraminifer-nannofossil ooze and chalk, variations in physical properties are very small. Variations of compressional wave velocity in the horizontal direction range between 1.55 and $1.63 \mathrm{~km} / \mathrm{s}$, and show gradual increase with depth, with a gradient of $1.5 \% / 100 \mathrm{~m}$ (Fig. 12). These properties are concordant with those previously obtained at Site 289 (Andrews, Packham, et al., 1975), which is located within $2 \mathrm{~km}$ southeast of Site 586 .

Values of compressional wave velocity measured under laboratory condition are, however, considerably smaller than those obtained by the Schlumberger Borehole Compensated Velocity Log as shown in Figure 13, in which a fluctuated curve indicates the logging data. Relative differences of core-averaged values indicate nearly linear increase with depth from just below the bottom of the casing to $300 \mathrm{~m}$ sub-bottom depth (as shown in Fig. 13 at the right). This discrepancy can be explained 


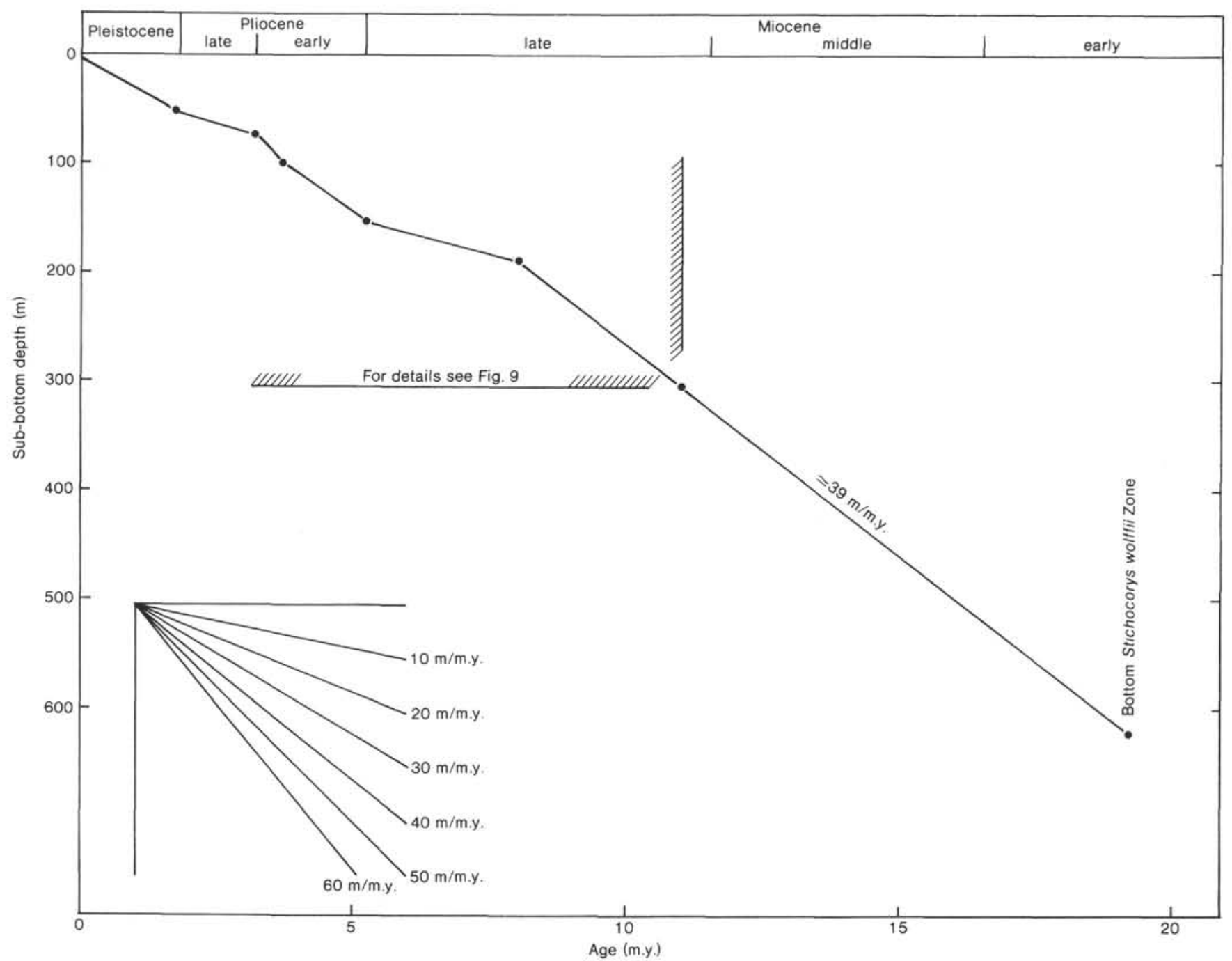

Figure 10. Sedimentation rates of Hole $586 \mathrm{C}$ from $300 \mathrm{~m}$ sub-bottom to total depth. The upper part is replotted from Figure 9 at a different (larger) scale.

Table 3. Carbonate carbon and organic carbon $\left(\mathrm{C}_{\text {org }}\right)$ data from Site 586.

\begin{tabular}{lrr}
\hline $\begin{array}{c}\text { Sample } \\
\text { (interval in cm) }\end{array}$ & $\begin{array}{c}\mathrm{CaCO}_{3} \\
(\%)\end{array}$ & $\begin{array}{c}\mathrm{C}_{\text {org }} \\
(\%)\end{array}$ \\
\hline Hole 586 & & \\
& & \\
$1-1,31-32$ & 84 & 0.36 \\
$5-2,105-106$ & 89 & 0.29 \\
& & \\
Hole 586A & & \\
& & \\
$1-2,79-80$ & 88 & 0.29 \\
$2-3,70-71$ & 88 & 0.24 \\
$5-2,75-76$ & 90 & 0.28 \\
$8-2,31-32$ & 85 & 0.62 \\
$9-2,27-28$ & 99 & $<0.01$ \\
$12-2,64-65$ & 96 & $<0.01$ \\
$15-2,60-61$ & 98 & 0.02 \\
$18-2,60-61$ & 99 & 0.01 \\
$20-2,82-83$ & 98 & 0.01 \\
$21-4,108-109$ & 95 & 0.03 \\
$23-5,82-83$ & 97 & $<0.01$ \\
$26-3,75-76$ & 93 & $<0.01$ \\
$28-4,45-46$ & 99 & $<0.01$ \\
$30-1,54-55$ & 96 & $<0.01$ \\
\hline
\end{tabular}

by porosity rebound, as pointed out by Boyce (1976b), Hamilton (1976), and Shepard et al. (1982).

For unconsolidated sediments, especially those which under laboratory conditions include gas bubbles, the release of pressure causes a considerable increase of porosity and decrease of velocity. The first appearance of tiny bubbles was at a sub-bottom depth of about $150 \mathrm{~m}$ after the cores were equilibrated with room temperature. During the velocity measurements, effects of bubbles on the weakening of signal amplitude were noticeable only for the sections indicated by "Gas" in the Remarks column of Table 7. To estimate in situ values by using laboratory measurements, it is necessary to know either the amount of dissolved gas components in pore water at depth or volume fractions of gas bubbles under laboratory conditions. It is recommended that a technique be developed to measure physical properties of unconsolidated sediments under bubble-free conditions in the shipboard laboratory.

\section{LOGGING AND DOWNHOLE MEASUREMENTS}

Two complete logging runs were made in Hole 586C, covering the interval from the mud line to a total depth 
Table 4. Shipboard inorganic chemistry summary, Site 586.

\begin{tabular}{|c|c|c|c|c|c|c|c|}
\hline $\begin{array}{l}\text { Laboratory } \\
\text { sample no. }\end{array}$ & $\begin{array}{c}\text { Sample } \\
\text { (interval in cm) }\end{array}$ & $\mathrm{pH}$ & $\begin{array}{c}\text { Alkalinity } \\
\text { (meq/l) }\end{array}$ & $\begin{array}{c}\text { Salinity } \\
\left(\$ \%_{0}\right)\end{array}$ & $\begin{array}{l}\text { Calcium } \\
(\mathrm{mmol} / \mathrm{l})\end{array}$ & $\underset{(\mathrm{mmol} / \mathrm{l})}{\text { Magnesium }}$ & $\begin{array}{c}\text { Chlorinity } \\
\left(\% 0_{0}\right)\end{array}$ \\
\hline \multicolumn{2}{|c|}{ Surface seawater } & 7.13 & 2.97 & 34.1 & 10.69 & 51.38 & 19.44 \\
\hline \multicolumn{8}{|l|}{ Hole 586} \\
\hline 1 & $2-2,140-150$ & 7.31 & 4.10 & 34.9 & 11.01 & 52.79 & 17.05 \\
\hline \multicolumn{8}{|l|}{ Hole $586 \mathrm{~A}$} \\
\hline 2 & $2-5,140-150$ & 6.83 & 4.93 & 34.9 & 11.10 & 54.59 & 20.02 \\
\hline 3 & $7-5,140-150$ & 7.12 & 5.432 & 34.9 & 11.70 & 49.40 & 19.92 \\
\hline 4 & $14-5,140-150$ & 7.18 & 5.906 & 33.6 & 13.35 & 47.86 & 21.67 \\
\hline 5 & $21-5,140-150$ & 7.10 & 6.29 & 34.1 & 15.08 & 46.50 & 19.88 \\
\hline 6 & $28-2,140-150$ & 7.07 & 5.804 & 34.6 & 15.98 & 43.17 & 20.25 \\
\hline \multicolumn{8}{|c|}{ IAPSO standard } \\
\hline 19.24 & & & & & & 10.33 & 52.32 \\
\hline
\end{tabular}

Table 5. Titration summary: $\mathrm{Ca}, \mathrm{Mg}, \mathrm{Cl}$, Site 586 .

\begin{tabular}{lccc}
\hline \multicolumn{1}{c}{ Sample } & A. ml titrant & B. Std. conc. & Factor C- $\beta / \mathrm{A}$ \\
\hline Calcium & $0.525 / 0.526$ & $10.55 \mathrm{mM} / 1$ & 20.10 \\
Magnesium & $1.125 / 1.126$ & $64.54 \mathrm{mM} / 1$ & 57.37 \\
Chlorinity & $0.576 / 0.577$ & $19.375 \% 0$ & \\
\hline
\end{tabular}

\begin{tabular}{|c|c|c|c|c|c|c|c|}
\hline \multirow[b]{2}{*}{$\begin{array}{c}\text { Sample } \\
\text { (interval in } \mathrm{cm} \text { ) }\end{array}$} & \multicolumn{2}{|c|}{ Calcium } & \multicolumn{3}{|c|}{ Magnesium } & \multicolumn{2}{|c|}{ Chlorinity } \\
\hline & $\begin{array}{c}\mathrm{ml} \\
\text { E.G.T.A. }\end{array}$ & $\begin{array}{c}\mathrm{X} \text { factor } \\
20.10\end{array}$ & $\begin{array}{c}\mathrm{ml} \\
\text { E.D.T.A. }\end{array}$ & $\begin{array}{c}X \text { factor } \\
57.37\end{array}$ & minus $\mathrm{Ca}$ & $\begin{array}{c}\mathrm{ml} \\
\mathrm{AgNO}_{3}\end{array}$ & $\begin{array}{c}X \text { factor } \\
33.70\end{array}$ \\
\hline Surface seawater & 0.532 & 10.69 & 1.082 & 62.07 & 51.38 & 0.577 & 19.44 \\
\hline \multicolumn{8}{|l|}{ Hole 586} \\
\hline $2-2,140-150$ & 0.548 & 11.01 & 1.112 & 63.80 & 52.79 & 0.506 & 17.05 \\
\hline \multicolumn{8}{|l|}{ Hole $586 \mathrm{~A}$} \\
\hline $2-5,140-150$ & 0.552 & 11.10 & 1.145 & 65.69 & 54.59 & 0.594 & 20.02 \\
\hline $7-5,140-150$ & 0.582 & 11.70 & 1.065 & 61.10 & 49.40 & 0.591 & 19.92 \\
\hline $14-5,140-150$ & 0.664 & 13.35 & 1.067 & 61.21 & 47.86 & 0.643 & 21.67 \\
\hline $21-5,140-150$ & 0.750 & 15.08 & 1.089 & 62.48 & 46.50 & 0.590 & 19.83 \\
\hline $28-2,140-150$ & 0.795 & 15.98 & 1.031 & 59.15 & 43.17 & 0.601 & 20.25 \\
\hline IAPSO & 0.514 & 10.33 & 1.091 & 62.65 & 52.32 & 0.571 & 19.24 \\
\hline
\end{tabular}

of $623 \mathrm{~m}$ in the hole. Strata at that depth are nannofossil chalks of early Miocene age. The first log run included caliper, gamma ray, resistivity, and sonic velocity; spontaneous potential $\log (\mathrm{SP})$ was taken but not printed. The second run included gamma ray, formation density compensated $\log$ (FDC), compensated neutron log (CNI), and caliper. A third, a repeat run, was made following the second run. (See Figs. 14 and 15.) Shorebased work in the future will include an impedance log to be made by combining sonic velocity and density logs. From this log a synthetic seismogram will be generated and compared to the air and water gun profiles made during the leg (see Operations section; Schlanger, pers. comm., 1984).

The logs will also be used as comparative material with which to evaluate shipboard velocity and porosity measurements (see section on Physical Properties). Finally when the log data are combined with paleontologi- cal data (see Biostratigraphy section) the numerous reflectors seen on seismic profiles across the Ontong-Java Plateau may be realistically interpreted in terms of their nature, origin, and relationship to paleoceanographic events.

\section{SEISMIC STRATIGRAPHY}

Seismic profiles that are run across oceanic areas in which thick caps of relatively pure nannofossil- and foraminifer-rich oozes, chalks, and limestones have accumulated generally display numerous, closely spaced reflectors that persist laterally for tens of miles or more. The "signature" and spacing of these reflectors change, of course, with the seismic source and the filter bandpass settings used for recording. The development or expression of these reflectors is particularly marked on oceanic plateaus such as the Ontong-Java Plateau (Fig. 3) and the Magellan Rise, among others. These reflectors 


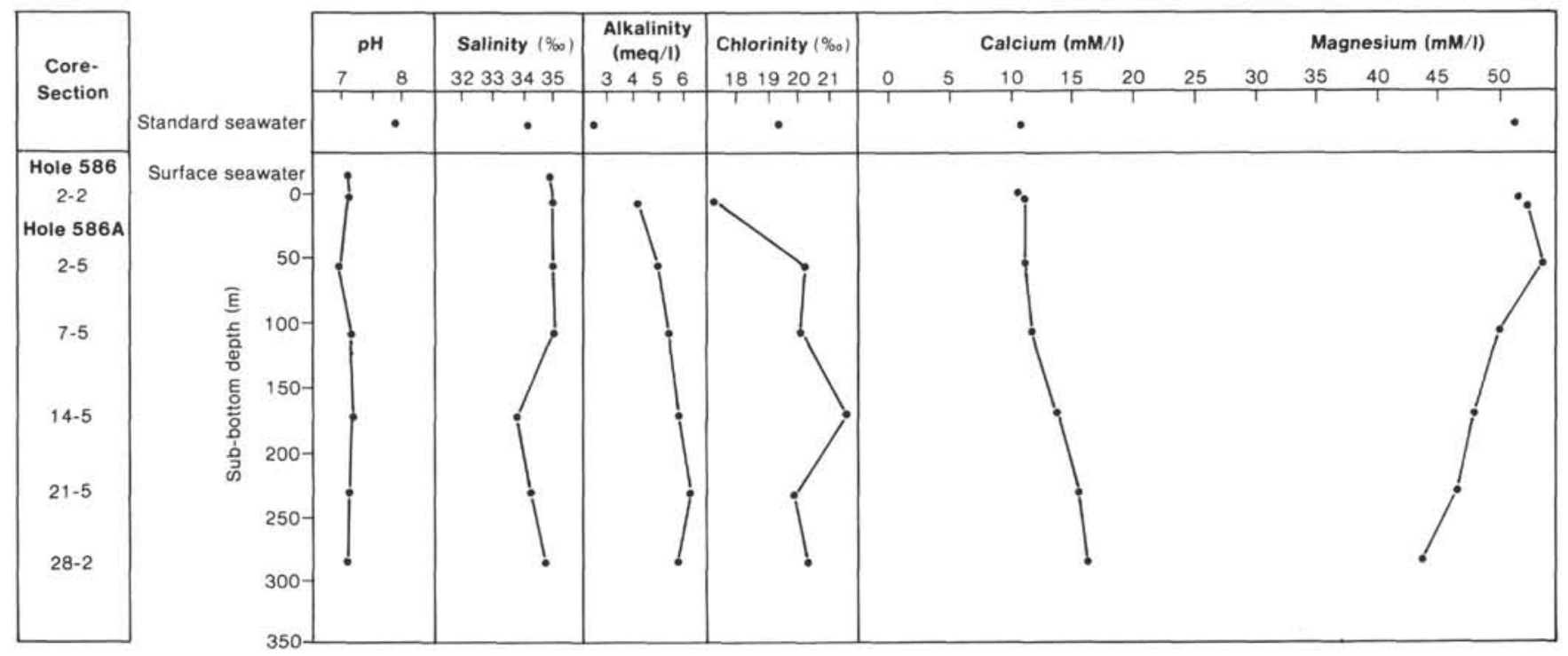

Figure 11. Interstitial water chemistry, Holes 586 and 586A.

Table 6. Locations of the most prominent high-intensity spikes in Hole 586B.

\begin{tabular}{lcclcc}
\hline $\begin{array}{l}\text { Core-Section } \\
(\text { level in cm) }\end{array}$ & $\begin{array}{c}\text { Depth } \\
(\mathrm{m})\end{array}$ & $\begin{array}{c}\text { Intensity } \\
(\mu \mathrm{G})\end{array}$ & $\begin{array}{c}\text { Core-Section } \\
(\text { level in cm) }\end{array}$ & $\begin{array}{c}\text { Depth } \\
(\mathrm{m})\end{array}$ & $\begin{array}{c}\text { Intensity } \\
(\mu \mathrm{G})\end{array}$ \\
\hline $3-4,100$ & 24.70 & 0.298 & $4-2,25$ & 30.55 & 0.382 \\
$4-4,100$ & 34.30 & 0.500 & $5-2,25$ & 40.15 & 0.368 \\
$7-1,25$ & 57.85 & 0.480 & $8-5,25$ & 73.45 & 0.127 \\
$11-2,27$ & 96.67 & 0.169 & $14-3,102$ & 127.72 & 0.174 \\
$15-3,25$ & 136.55 & 0.184 & $16-5,105$ & 149.95 & 0.527 \\
$17-3,25$ & 155.75 & 0.747 & $17-5,28$ & 158.78 & 1.022 \\
$19-1,98$ & 172.68 & 0.299 & $21-4,25$ & 195.65 & 0.216 \\
$22-2,100$ & 203.00 & 0.270 & $22-4,100$ & 206.00 & 0.160 \\
$23-4,100$ & 215.60 & 0.165 & $23-6,100$ & 218.60 & 1.177 \\
\hline
\end{tabular}

have intrigued many stratigraphers since the early legs of the DSDP (Winterer, Riedel, et al., 1971; Moberly and Heath, 1971).

Drilling at such DSDP sites as 64,288 , and 289 on the Ontong-Java Plateau produced an enormous amount of physical properties data which, when combined with paleontological and, in some cases, drilling rate data, resulted in attempts to date and explain the origin of the reflectors (e.g., van der Lingen and Packham, 1975). It had become clear by the middle 1970s that, although the source of the reflectors lay in subtle acoustic impedance differences between carbonate layers, it was not obvious if these impedance differences were due to some combination of sedimentation rate changes, variations in microfossil content, and diagenetic effects. If a section of pure carbonate of invariant texture simply underwent compaction, no marked impedance differences would develop in the column and so there would be no reflectors. One problem that arose early in the interpretation of the origin of the reflectors was derived from the fact that the acoustic velocities and density values measured aboard ship showed very little variation downhole, particularly in the upper several hundreds of meters.

The discovery, by drilling, that chalk layers could be interbedded with relatively uncemented oozes led to the idea that cementation within these carbonate columns was not strictly depth-dependent but might be a function of the original composition of the layers, which, in turn, might be a function of paleoceanographic conditions. Schlanger and Douglas (1974) applied these ideas to the development of a model for the carbonate oozechalk-limestone transition and related certain reflectors to paleoceanographic events such as glaciations.

All of this history is built into the interpretation of the seismic stratigraphy of the Site 289 area shown on Figure 3. What is new about this version is that logging was carried out to a depth of $623 \mathrm{~m}$ in Hole 586C (see sections on Physical Properties, Logging and Downhole Measurements). The sonic velocity log showed that in situ velocities are considerably higher than those measured aboard ship. A preliminary impedance log showed significant vertical variation.

The interpretation shown on Figure 3 is based on:

1. The sonic velocity, formation density, and compensated neutron logs.

2. Data from the drilling of Site 289 on Leg 30 .

3. Paleontological data from Site 289 .

4. Paleontological and sedimentation rate data from Leg 89.

This interpretation is provisional and it is planned to revise it after the logs run in the hole are processed ashore, at which time a refined impedance log will be provided as well as a reflection coefficient log; these could then be used to produce synthetic seismograms which, it is hoped, would eliminate most acoustic artifacts (Schlanger, pers. comm., 1984).

\section{SUMMARY AND CONCLUSIONS}

\section{Holes 586, 586A, and 586C}

Site 586 was planned by the JOIDES Ocean Paleoenvironment Panel essentially as a redrilling, by use of the hydraulic piston corer, of the upper section of DSDP Site 289 , which was originally drilled on Leg 30 to a 
Table 7A. Physical properties of sediments, Site 586: Porosity, wetbulk density, water content, and grain density.

\begin{tabular}{cccccc}
\hline $\begin{array}{c}\text { Sample } \\
\text { (level in cm) }\end{array}$ & $\begin{array}{c}\text { Sub-bottom } \\
\text { depth } \\
(\mathrm{m})\end{array}$ & $\begin{array}{c}\text { Porosity } \\
(\%)\end{array}$ & $\begin{array}{c}\text { Wet-bulk } \\
\text { density } \\
\left(\mathrm{g} / \mathrm{cm}^{3}\right)\end{array}$ & $\begin{array}{c}\text { Water } \\
\text { content } \\
(\%)\end{array}$ & $\begin{array}{c}\text { Grai } \\
\text { densi } \\
(\mathrm{g} / \mathrm{cm}\end{array}$ \\
\hline Hole 586 & & & & & \\
& & & & & \\
$2-1,60$ & 6.0 & 66.0 & 1.47 & 44.8 & 2.39 \\
$2-3,75$ & 9.2 & 48.6 & 1.49 & 32.6 & 1.95 \\
$2-5,75$ & 12.2 & 64.4 & 1.47 & 43.7 & 2.34 \\
$4-1,72$ & 26.1 & 68.0 & 1.56 & 43.5 & 2.76 \\
$4-3,75$ & 29.2 & 60.0 & 1.55 & 38.6 & 2.38 \\
$4-5,75$ & 32.2 & 63.0 & 1.59 & 39.7 & 2.59 \\
$5-1,70$ & 35.6 & 66.1 & 1.60 & 41.4 & 2.76 \\
$5-3.71$ & 38.6 & 63.5 & 1.54 & 41.2 & 2.49 \\
$5-5,75$ & 41.7 & 67.9 & 1.58 & 43.0 & 2.81 \\
& & & & &
\end{tabular}

Hole 586

\begin{tabular}{|c|c|c|c|c|c|}
\hline $1-1,71$ & 45.1 & 58 & 1,48 & 39 & 2.16 \\
\hline $1-3,71$ & 48.1 & 54 & 1.34 & 40 & 1.73 \\
\hline $1-5,71$ & 51.1 & 64 & 1.53 & 42 & 2.49 \\
\hline $2-1,71$ & 54.7 & 63 & 1.49 & 43 & 2.30 \\
\hline $2-3,71$ & 57.7 & 57 & 1.60 & 36 & 2.39 \\
\hline $2-5,71$ & 60.7 & 62 & 1.66 & 38 & 2.70 \\
\hline $3.3,75$ & 67.4 & 63 & 1.54 & 41 & 2.45 \\
\hline $3-5,75$ & 70.4 & 64 & 1.56 & 41 & 2.53 \\
\hline $4-1,70$ & 73.9 & 68 & 1.56 & 44 & 2.71 \\
\hline $4-3,70$ & 76.9 & 69 & 1.55 & 45 & 2.74 \\
\hline $4-5,70$ & 79.9 & 61 & 1.51 & 41 & 2.28 \\
\hline $5-1,70$ & 83.5 & 68 & 1.58 & 43 & 2.78 \\
\hline $5.3,70$ & 86.5 & 62 & 1.56 & 40 & 2.50 \\
\hline $5-5,70$ & 89.5 & 70 & 1.61 & 44 & 2.99 \\
\hline $6-2,70$ & 94.6 & 72 & 1.63 & 44 & 3.25 \\
\hline $6-4,70$ & 97.6 & 68 & 1.56 & 43 & 2.78 \\
\hline $6-6,70$ & 100.6 & 64 & 1.64 & 39 & 2.68 \\
\hline $7-1,70$ & 102.7 & 67 & 1.65 & 40 & 3.00 \\
\hline $7 \cdot 3,70$ & 105.7 & 62 & 1.50 & 41 & 2.37 \\
\hline $7-5,70$ & 108.7 & 65 & 1.61 & 40 & 2.75 \\
\hline $8.1,70$ & 112.3 & 64 & 1.60 & 40 & 2.65 \\
\hline $8-3,70$ & 115.7 & 64 & 1.58 & 41 & 2.58 \\
\hline $8-5,70$ & 118.3 & 65 & 1.62 & 40 & 2.79 \\
\hline $9.1,70$ & 121.9 & 87 & 1.71 & 51 & 1.49 \\
\hline $9.3,70$ & 124.9 & 31 & 1.28 & 24 & 1.41 \\
\hline $9-6,70$ & 127.9 & 58 & 1.40 & 41 & 1.95 \\
\hline $10-1,70$ & 131.5 & 55 & 1.62 & 34 & 2.39 \\
\hline $10-3,70$ & 134.5 & 58 & 1.55 & 37 & 2.32 \\
\hline $10-5,70$ & 137.5 & 61 & 1.62 & 38 & 2.59 \\
\hline $11-1,70$ & 141.1 & 59 & 1.51 & 39 & 2.21 \\
\hline $11-3,70$ & 144.1 & 62 & 1.57 & 40 & 2.48 \\
\hline $11-5,70$ & 147.1 & 58 & 1.51 & 38 & 2.22 \\
\hline $12-1,70$ & 150.7 & 57 & 1.46 & 39 & 2.06 \\
\hline $12-3,70$ & 153.7 & 50 & 1.29 & 39 & 1.57 \\
\hline $12-5,70$ & 156.7 & 62 & 1.71 & 36 & 2.85 \\
\hline $13-1,70$ & 160.3 & 47 & 1.25 & 38 & 1.45 \\
\hline $13-3,70$ & 163.3 & 65 & 1.59 & 41 & 2.72 \\
\hline $13-5,70$ & 166.3 & 61 & 1.51 & 40 & 2.31 \\
\hline $14-1,70$ & 167.6 & 47 & 1.25 & 38 & 1.45 \\
\hline $14-3,70$ & 170.6 & 63 & 1.62 & 39 & 2.64 \\
\hline $15-1,70$ & 182.5 & 59 & 1.65 & 36 & 2.58 \\
\hline $15-3,70$ & 175.5 & 63 & 1.65 & 39 & 2.71 \\
\hline $15-5,70$ & 178.5 & 51 & 1.45 & 35 & 1.89 \\
\hline $16-1,70$ & 181.5 & 63 & 1.66 & 38 & 2.77 \\
\hline $16-3,70$ & 184.5 & 56 & 1.57 & 36 & 2.30 \\
\hline $16-5,70$ & 187.5 & 70 & 1.64 & 43 & 3.11 \\
\hline $17-1,70$ & 191.1 & 61 & 1.67 & 36 & 2.70 \\
\hline $17-3,70$ & 194.1 & 71 & 1.78 & 40 & 3.74 \\
\hline $17-5,70$ & 197.1 & 54 & 1.46 & 37 & 1.97 \\
\hline $18-1,70$ & 200.7 & 54 & 1.56 & 34 & 2.24 \\
\hline $18-3,70$ & 203.7 & 62 & 1.69 & 37 & 2.81 \\
\hline $18.5,70$ & 206.7 & 53 & 1.57 & 34 & 2.21 \\
\hline $19-1,70$ & 210.3 & 67 & 1.75 & 38 & 3.31 \\
\hline $19-3,70$ & 213.3 & 58 & 1.64 & 35 & 2.53 \\
\hline $19-5,70$ & 216.3 & 53 & 1.54 & 34 & 2.17 \\
\hline $20-1,70$ & 218.8 & 51 & 1.52 & 34 & 2.03 \\
\hline $20-3,70$ & 221.8 & 59 & 1.54 & 38 & 2.59 \\
\hline $20-5.70$ & 224.8 & 48 & 1.32 & 36 & 1.63 \\
\hline $21-3,71$ & 228.4 & 57 & 1.62 & 35 & 2.46 \\
\hline $21-5,70$ & 231.4 & 52 & 1.55 & 34 & 2.15 \\
\hline $21-7,70$ & 234.4 & 66 & 1.58 & 42 & 2.72 \\
\hline $22-1,70$ & 238.0 & 58 & 1.66 & 35 & 2.61 \\
\hline $22-3,70$ & 241.0 & 56 & 1.61 & 35 & 2.40 \\
\hline $22.5,70$ & 244.0 & 35 & 1.52 & 36 & 2.15 \\
\hline $23-1,70$ & 247.6 & 56 & 1.52 & 37 & 2.17 \\
\hline $23-3,70$ & 250.6 & 57 & 1.61 & 35 & 2.43 \\
\hline $23-5,70$ & 253.6 & 58 & 1.64 & 35 & 2.53 \\
\hline $24-1,70$ & 257.2 & 55 & 1.62 & 34 & 2.36 \\
\hline $24-3,70$ & 260.2 & 58 & 1.58 & 37 & 2.38 \\
\hline $24-5,70$ & 263.2 & 58 & 1.65 & 35 & 2.54 \\
\hline $25-1,70$ & 266.8 & 57 & 1.62 & 35 & 2.44 \\
\hline $25-3,70$ & 269.8 & 56 & 1.50 & 38 & 2.12 \\
\hline $25-5,70$ & 272.8 & 58 & 1.63 & 36 & 2.51 \\
\hline $26-1,71$ & 276.4 & 48 & 1.61 & 30 & 2.17 \\
\hline $26-2,71$ & 277.9 & 72 & 1.57 & 46 & 3.04 \\
\hline $26-3,71$ & 279.4 & 34 & 1.24 & 27 & 1.37 \\
\hline $27-1,71$ & 282.4 & 62 & 1.62 & 38 & 2.65 \\
\hline $27-3,71$ & 285.4 & 59 & 1.50 & 39 & 2.21 \\
\hline $28-3,71$ & 289.6 & 55 & 1.56 & 35 & 2.22 \\
\hline $29-1,71$ & 291.0 & 49 & 1.38 & 36 & 1.72 \\
\hline $29-3,71$ & 294.0 & 53 & 1.49 & 36 & 2.04 \\
\hline $30-1,71$ & 296.0 & 54 & 1.48 & 37 & 2.02 \\
\hline $30-3,71$ & 299.0 & 54 & 1.56 & 34 & 2.24 \\
\hline $31-1,71$ & 301.0 & 52 & 1.48 & 35 & 2.00 \\
\hline $31-3,71$ & 304.0 & 52 & 1.56 & 33 & 2.17 \\
\hline
\end{tabular}

Note: Sub-bottom depths are based opon original shipboard calculation and may be in errot by $5.1 \mathrm{~m}$.
Table 7B. Physical properties of sediments, Site 586: Compressional wave velocity, wet-bulk density, and impedance.

\begin{tabular}{|c|c|c|c|c|c|}
\hline $\begin{array}{c}\text { Sample } \\
\text { (level in } \mathrm{cm} \text { ) }\end{array}$ & $\begin{array}{l}\text { Sub-bottom } \\
\text { depth } \\
\text { (m) }\end{array}$ & $\begin{array}{l}\text { Compressional- } \\
\text { wave } \\
\text { velocity } \\
(\mathrm{km} / \mathrm{s})\end{array}$ & $\begin{array}{l}\text { Wet-bulk } \\
\text { density } \\
\left(\mathrm{g} / \mathrm{cm}^{3}\right)\end{array}$ & $\begin{array}{l}\text { Impedance }{ }^{\mathrm{b}} \\
\left(10^{5} \mathrm{~g} / \mathrm{cm}^{2} \mathrm{~s}\right)\end{array}$ & Rerharks $^{c}$ \\
\hline \multicolumn{6}{|l|}{ Hole 586A } \\
\hline $22-5,50$ & 243.8 & 1.62 & & & \\
\hline $22-5,100$ & 244.3 & 1.62 & & & \\
\hline $22-6,50$ & 245.3 & 1.63 & & & \\
\hline $22-6,100$ & 246.3 & 1.62 & & & \\
\hline $23-1,50$ & 247.3 & 1.60 & & & \\
\hline $23-1,100$ & 247.9 & 1.61 & & & \\
\hline $23-2,50$ & 248.9 & 1.61 & 1.77 & 2.85 & \\
\hline $23-2,100$ & 249.4 & 1.62 & 1.75 & 2.84 & \\
\hline $23-3,50$ & 250.4 & 1.60 & & & Gas \\
\hline $23-3,100$ & 250.9 & 1.59 & & & Gas \\
\hline $23-4,50$ & 251.9 & 1.60 & 1.76 & 2.82 & \\
\hline $23-4,100$ & 252.4 & 1.59 & 1.76 & 2.80 & \\
\hline $23-5,50$ & 253.4 & 1.61 & & & \\
\hline $23-5,100$ & 253.9 & 1.60 & & & \\
\hline $23-6,50$ & 254.9 & 1.60 & 1.77 & 2.83 & \\
\hline $23-6,100$ & 255.4 & 1.61 & 1.77 & 2.85 & \\
\hline $24-1,50$ & 257.0 & 1.60 & & & \\
\hline $24-1,100$ & 257.5 & 1.61 & & & \\
\hline $24-2,50$ & 258.5 & 1.60 & 1.75 & 2.80 & \\
\hline $24.2,100$ & 259.0 & 1.58 & 1.75 & 2.77 & \\
\hline $24-3,50$ & 260.0 & 1.58 & & & \\
\hline $24-3,100$ & 260.5 & 1.58 & & & \\
\hline $24-4,50$ & 261.5 & 1.58 & 1.73 & 2.73 & \\
\hline $24-4,100$ & 262.5 & 1.59 & 1.73 & 2.75 & \\
\hline
\end{tabular}

$\begin{array}{ll}1.76 & 2.83 \\ 1.76 & 2.80 \\ & \\ 1.72 & 2.75 \\ 1.73 & 2.77\end{array}$

$1.80 \quad 2.93$

$\begin{array}{lll} & & \text { Gas } \\ & & \text { Gas } \\ 1.74 & 2.80 & \text { Gas } \\ 1.74 & 2.78 & \text { Gas } \\ & & \text { Gas }\end{array}$

$\begin{array}{ll}1.73 & 2.77\end{array}$

$\begin{array}{lll} & & \text { Gas } \\ 1.77 & 2.81 & \text { Gas } \\ 1.75 & 2.78 & \text { Gas } \\ & & \text { Gas }\end{array}$

$1.75 \quad 2.84$

$1.73 \quad 2.75$

$\begin{array}{ll}1.76 & 2.82 \\ 1.78 & 2.85\end{array}$

$\begin{array}{ll}1.75 & 2.80 \\ 1.77 & 2.83\end{array}$

Hole 586B

$\begin{array}{ll}1-4,50 & 10 . \\ 1-4,100 & 10 . \\ 2-4,50 & 16 . \\ 2-4,100 & 16.5 \\ 3-4,50 & 25 . \\ 3-4,100 & 27 . \\ 4-4,50 & 35.2\end{array}$

$\begin{array}{ll}1.60 & 2.48 \\ 1.62 & 2.53 \\ 1.62 & 2.56 \\ 1.62 & 2.53 \\ 1.65^{\circ} & 2.62 \\ 1.65^{\circ} & 2.57 \\ 1.63 & 2.56\end{array}$


Table 7B. (Continued).

\begin{tabular}{|c|c|c|c|c|c|}
\hline $\begin{array}{c}\text { Sample } \\
\text { (level in } \mathrm{cm} \text { ) }\end{array}$ & $\begin{array}{l}\text { Sub-bottom } \\
\text { depth } \\
\text { (m) }\end{array}$ & $\begin{array}{c}\text { Compressional- } \\
\text { wave } \\
\text { velocity } \\
(\mathrm{km} / \mathrm{s})\end{array}$ & $\begin{array}{l}\text { Wet-bulk } \\
\text { density } \\
\left(\mathrm{g} / \mathrm{cm}^{3}\right)\end{array}$ & $\begin{array}{c}\text { Impedance }^{\mathrm{b}} \\
\left(10^{5} \mathrm{~g} / \mathrm{cm}^{2} \mathrm{~s}\right)\end{array}$ & Remarks $^{c}$ \\
\hline
\end{tabular}

Hole 586B (Cont.)

\begin{tabular}{|c|c|c|c|c|c|}
\hline $4-4,100$ & 35.7 & 1.56 & 1.65 & 2.57 & \\
\hline $5 \cdot 4,50$ & 44.8 & 1.54 & 1.65 & 2.54 & \\
\hline $5-4,100$ & 45.3 & 1.57 & 1.63 & 2.56 & \\
\hline $6-4,50$ & 54.4 & 1.56 & 1.67 & 2.61 & \\
\hline $6-4,100$ & 54.9 & 1.60 & 1.63 & 2.67 & \\
\hline $7-4,50$ & 64.0 & 1.55 & $1.65^{*}$ & 2.56 & \\
\hline $7-4,100$ & 64.5 & 1.53 & $1.65^{*}$ & 2.52 & \\
\hline $8-4,50$ & 73.6 & 1.58 & $1.65^{\circ}$ & 2.61 & \\
\hline $8-4,100$ & 74.1 & 1.57 & $1.65^{\circ}$ & 2.59 & \\
\hline $9-4,50$ & 83.2 & 1.55 & 1.60 & 2.48 & \\
\hline $9-4,100$ & 83.7 & 1.56 & 1.63 & 2.54 & \\
\hline $10-4,50$ & 92.8 & 1.58 & 1.67 & 2.64 & \\
\hline $10-4,100$ & 93.3 & 1.58 & 1.68 & 2.65 & \\
\hline $11-4,50$ & 101.3 & 1.57 & 1.69 & 2.65 & \\
\hline $11-4,100$ & 101.8 & 1.57 & 1.70 & 2.67 & \\
\hline $12-4,50$ & 110.9 & 1.57 & 1.70 & 2.67 & \\
\hline $12-4,100$ & 111.4 & 1.58 & 1.70 & 2.69 & \\
\hline $13-4,50$ & 120.5 & 1.59 & 1.74 & 2.77 & \\
\hline $13-4,100$ & 121.0 & 1.56 & 1.74 & 2.71 & \\
\hline $14-4,50$ & 130.1 & 1.57 & 1.68 & 2.64 & \\
\hline $14-4,100$ & 130.6 & 1.57 & 1.70 & 2.67 & \\
\hline $15-4,50$ & 139.7 & 1.59 & 1.68 & 2.67 & \\
\hline $15-4,100$ & 140.2 & 1.56 & 1.65 & 2.57 & \\
\hline $16-4,50$ & 149.3 & 1.58 & 1.73 & 2.73 & \\
\hline $16-4,100$ & 149.8 & 1.58 & 1.74 & 2.75 & \\
\hline $17-4,50$ & 158.9 & 1.61 & 1.72 & 2.77 & \\
\hline $17-4,100$ & 159.4 & 1.58 & 1.68 & 2.65 & \\
\hline $18-4,50$ & 168.4 & 1.58 & 1.71 & 2.70 & \\
\hline $18-4,100$ & 169.0 & 1.57 & 1.70 & 2.67 & \\
\hline $19-4,50$ & 178.1 & 1.59 & 1.72 & 2.73 & \\
\hline $19-4,100$ & 178.6 & 1.58 & 1.72 & 2.72 & \\
\hline $20-4,50$ & 187.7 & 1.60 & 1.71 & 2.74 & Gas \\
\hline $20-4,100$ & 188.2 & 1.61 & 1.70 & 2.74 & \\
\hline $21-4,50$ & 197.3 & 1.60 & 1.70 & 2.72 & Gas \\
\hline $21-4,100$ & 197.8 & 1.59 & 1.72 & 2.73 & Gas \\
\hline $22-4,50$ & 206.9 & 1.62 & 1.75 & 2.84 & Gas \\
\hline $22-4,100$ & 207.4 & 1.62 & 1.73 & 2.80 & Gas \\
\hline $23-4,50$ & 216.5 & 1.60 & 1.70 & 2.72 & Gas \\
\hline $23-4,100$ & 217.0 & 1.59 & 1.72 & 2.73 & Gas \\
\hline $24-4,50$ & 226.1 & 1.58 & 1.73 & 2.73 & \\
\hline $24-4,100$ & 226.6 & 1.60 & 1.75 & 2.80 & \\
\hline $25-4,50$ & 235.7 & 1.60 & 1.76 & 2.82 & \\
\hline $25-4,100$ & 236.2 & 1.61 & 1.78 & 2.87 & \\
\hline
\end{tabular}

Note: Sub-bottom depths are based upon original shipboard calculations and may be in error by $5.1 \mathrm{~m}$.

Measured by continuous GRAPE.

Calculated from wet-bulk density measured by continuous GRAPE.

c "Gas" indicates the noticeable weakening of acoustic signals by gas bubbles.

depth of $1262.5 \mathrm{~m}$, bottoming in Aptian limestones underlain by basalt. Details of the original results can be referred to in Andrews, Packham, et al. (1975). The purpose of reoccupying Site 289 was to obtain a detailed Neogene sediment record to understand better the paleoceanographic history on an equatorial shallow-water rise which had accumulated almost pure foraminiferal and nannofossil carbonates at high sedimentation rates. Site 586 is the northernmost of a series of HPC sites, the rest of which were drilled on Leg 90 in the southwest Pacific.

Four holes were drilled at Site 586; Hole 586 ended when a core barrel sub broke at $39.3 \mathrm{~m}$ depth; Hole 586A was continuously cored between 39.3 and $300.2 \mathrm{~m}$; Hole 586B penetrated to $240.3 \mathrm{~m}$ sub-bottom. The entire section consists of foraminiferal and nannofossil ooze which became chalky at a depth of approximately $260 \mathrm{~m}$. In Hole $586 \mathrm{~A}$ the oldest sediments cored are of late Miocene age in the N16 foraminifer Zone, the CN7 nannofossil Zone, and the $C$. pettersoni radiolarian Zone. A fourth hole, $586 \mathrm{C}$, was washed to a depth of $613.5 \mathrm{~m}$ and a single core was taken at $613.5-623.1 \mathrm{~m}$ in the $S$. wolffii radiolarian Zone of early Miocene age. The purpose of this hole was to create an opportunity to log the pure carbonate section known to exist from Leg 30 data so as to acquire logs which would enable us to (1) compare shipboard physical properties data with in situ data on sonic velocities, densities, and impedance contrasts and ( 2 ) be better able to interpret the seismic stratigraphy of the Ontong-Java Plateau. To these ends the logging program was successful. Sonic velocities measured in the hole are significantly higher than shipboard measurements. These data combined with paleontological data allowed a new reinterpretation of the seismic reflectors (see section on Seismic Stratigraphy).

The paleontological studies of the Leg 89 group indicate that the carbonate section on the Ontong-Java Plateau is not the product of a purely pelagic "rain," but that the sediments probably contain allochthonous elements, as discussed later.

As shown by the foraminifer record, the sediments, which at first sight appear to display the sedimentological characteristics of a foraminifer-nannofossil ooze, were affected by mechanical transport, that caused (1) an accumulation of foraminiferal tests within the range of the sand fraction and (2) an admixture of forms from different environments, ranging from shallow-water platforms to bathyal depths. Thus, the sediments encountered at this site are more properly defined as a graded foraminifer-nannofossil silty sand.

Both planktonic and benthic foraminifers from the same sample show different preservation, the same species occurring with both transparent and chalky tests. It is not clear if the best preserved tests are autochthonous or allochthonous.

In addition, each residue contains specimens of Quinqueloculina, coarse agglutinated foraminifers, large nodosariids (one chamber was over $2 \mathrm{~mm}$ in size), and highly ornamented ostracodes indicative of an environment much shallower than the present water depth at Site 586, $2208 \mathrm{~m}$ (below sea level), or than the estimated bathyal paleodepth based on the supposed autochthonous benthic foraminifers. It is worth mentioning that evidence of obvious reworking could not be detected in this preliminary study, although it cannot be ruled out.

There is a large variation in the size of the radiolarian microfauna. The size fraction greater than $150 \mu \mathrm{m}$ is large in some samples and small in others. For example, in $586 \mathrm{~A}-8, \mathrm{CC}$ less than $1 \%$ of the assemblage is greater than $150 \mu \mathrm{m}$. A high percentage of small tests can be interpreted to result from an allochthonous, transported fauna; a high percentage of large tests indicates an autochthonous fauna.

Sedimentation ratios at the site varied considerably through time from a low of $13 \mathrm{~m} / \mathrm{m}$.y. in late Miocene time to a high of $54 \mathrm{~m} / \mathrm{m}$.y. in mid-Pliocene time, 3 to 4 m.y. ago.

\section{Hole 586B (by Leg 90 shipboard scientific party)}

The Leg 90 scientific team split, described, and dated the sequence at Hole 586B (Ontong-Java Plateau) collected during Leg 89 , with $98 \%$ recovery. This appears to be a continuous, uncomplicated section from Quater- 


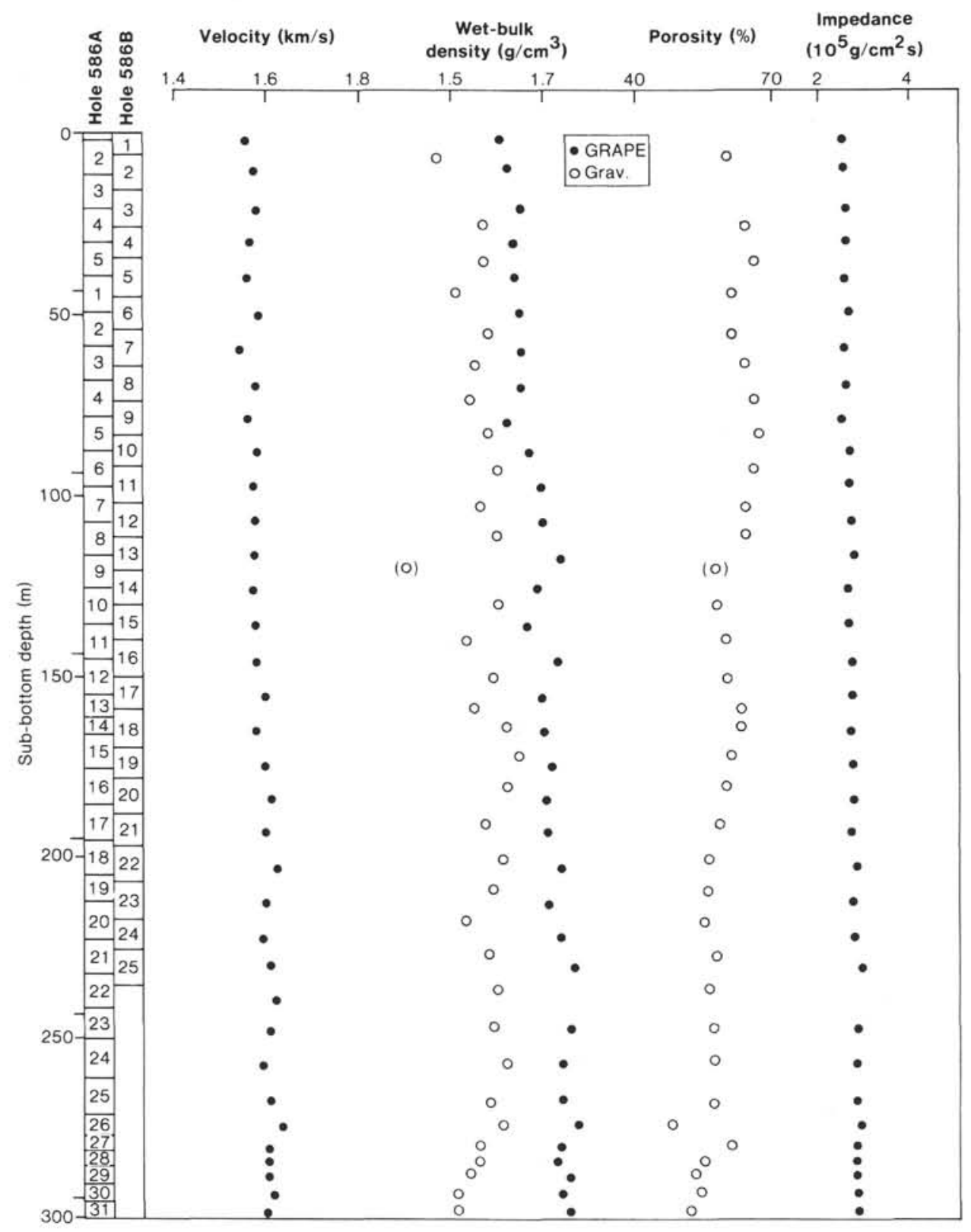

Figure 12. Variations of physical properties with depth at Site 586.

nary to early late Miocene age. Cores are generally of good quality except for severe disturbance within five of the cores. Hole 586B differs only in details from descriptions of Holes 586 and 586A. All major calcareous and siliceous microfossil groups are represented. The section is from one lithostratigraphic unit, composed of foraminifer-bearing to foraminifer-nannofossil ooze. The sequence is intensely bioturbated, with numerous sedimentary features related to bioturbation. The upper $45 \mathrm{~m}$ of the section is marked by numerous thin, foraminiferrich zones that apparently resulted from winnowing. Unlike the report for Hole 586, there is little evidence of extensive reworking or turbidite layers.

\section{REFERENCES}

Andrews, J. E., Packham, G. H., et al., 1975. Init. Repts. DSDP, 30: Washington (U.S. Govt. Printing Office).
Berggren, W. A., 1977. Late Neogene planktonic foraminiferal biostratigraphy of DSDP Site 357 (Rio Grande Rise). In Supko, P. R., Perch-Nielsen, K., et al., Init. Repts. DSDP, 39: Washington (U.S. Govt. Printing Office), 591-614.

Blow, W. H., 1969. Late middle Eocene to Recent planktonic foraminiferal biostratigraphy. Proc. Ist Int. Conf. Planktonic Microfossils (Vol. 1): Leiden (E. J. Brill), 199-422.

Boyce, R. E., 1976a. Definitions and laboratory techniques of compressional sound velocity parameters and wet-water content, wetbulk density, and porosity parameters by gravimetric and gamma ray attenuation techniques. In Schlanger, S. O., Jackson, E. D., et al., Init. Repts. DSDP, 33: Washington (U.S. Govt. Printing Office), 931-958.

1976b. Sound velocity-density parameters of sediment and rock from DSDP Sites $315-318$ on the Line Islands Chain, Manihiki Plateau, and Tuamotu Ridge in the Pacific Ocean. In Schlanger, S. O., Jackson, E. D., et al., Init. Repts. DSDP, 33: Washington (U.S. Govt. Printing Office), 931-958.

Ellis, C. H., 1982. Calcareous nannoplankton biostratigraphy-Deep Sea Drilling Project Leg 60. In Hussong, D. M., Uyeda, S., et al., 
Init. Repts. DSDP, 60: Washington (U.S. Govt. Printing Office), 507-536.

Gartner, S., 1977. Calcareous nannofossil biostratigraphy and revised zonation of the Pleistocene. Mar. Micropaleontol., 2:1-25.

Hamilton, E. L., 1976. Variations of density and porosity with depth in deep-sea sediments. J. Sed. Petrol., 46:280-300.

Mammerickx, J. L., Chase, T. E., Smith, S. M., and Taylor, I. L., 1974. Bathymetry of the South Pacific. IMR Technical Reports, Scripps Institution of Oceanography, La Jolla, California.

Martini, E., 1971. Standard Tertiary and Quaternary calcareous nannoplankton zonation. Proc. II Planktonic Conf., Roma: Rome (Ed. Tecnoscienza), pp. 739-785.

Milholland, P., Manghnani, M. H., Schlanger, S. O., and Sutton, G. H., 1980. Geoacoustic modelling of deep-sea carbonate sediments. J. Acoust. Soc. Am., 68:1351-1360.

Moberly, R., and Heath, G. R., 1971. Carbonate sedimentary rocks from the western Pacific: Leg 7, Deep Sea Drilling Project. In Winterer, E. L., Riedel, W. R., et al., Init. Repts. DSDP, 7, Pt. 2: Washington (U.S. Govt. Printing Office), 977-986.

Moberly, R., Schlanger, S. O., et al., in press. Init. Repts. DSDP, 89: Washington (U.S. Govt. Printing Office).

Nigrini, C., 1971. Radiolarian zones in the Quaternary of the equatorial Pacific Ocean. In Funnell, B. M., and Riedel, W. R. (Eds.), The Micropaleontology of the Oceans: London (Cambridge Univ. Press), pp. 443-461.

Okada, H., and Bukry, D., 1980. Supplementary modification and introduction of code numbers to the low-latitude coccolith biostratigraphic zonation (Bukry, 1973, 1975). Mar. Micropaleontol., 5: 321-325.
Riedel, W. R., and Sanfilippo, A., 1978. Stratigraphy and evolution of tropical Cenozoic radiolarians. Micropaleontology, 23(1):61-96.

Schlanger, S. O., and Douglas R. G., 1974. The pelagic ooze-chalk transition and its implications for marine stratigraphy. In Hsü, K. J., and Jenkyns, H. (Eds.), Pelagic Sediments on Land and under the Sea. Int. Assoc. Sed. Spec. Publ., 1:117-148.

Shepard, L. E., Bryant, W. R., and Chiou, W. A., 1982. Geotechnical properties of Middle America Trench sediments, Deep Sea Drilling Project, Leg 66. In Watkins, J. S., Moore, J. C., et al., Init. Repts. $D S D P, 66$ : Washington (U.S. Govt. Printing Office), 475-504.

Srinivasan, M. S., and Kennett, J., 1981. Neogene planktonic foraminiferal biostratigraphy and evolution: Equatorial to subantarctic, South Pacific. Mar. Micropaleontol., 6:499-533.

van der Lingen, G. J., and Packham, G., 1975. Relationships between diagenesis and physical properties of biogenic sediments of the Ontong-Java Plateau (Sites 288 and 289, Deep Sea Drilling Project). In Andrews, J. E., Packham, G., et al., Init. Repts. DSDP, 30: Washington (U.S. Govt. Printing Office), 443-482.

Vincent, E., 1981. Neogene planktonic foraminifers from the central North Pacific, Deep Sea Drilling Project Leg 62. In Thiede, J., Vallier, T. L., et al., Init. Repts. DSDP, 62: Washington (U.S. Govt. Printing Office), 329-353.

Winterer, E. L., and Riedel, W. R., et al., 1971. Init. Repts. DSDP, 7 : Washington (U.S. Govt. Printing Office).

Date of Acceptance: 12 January 1983 

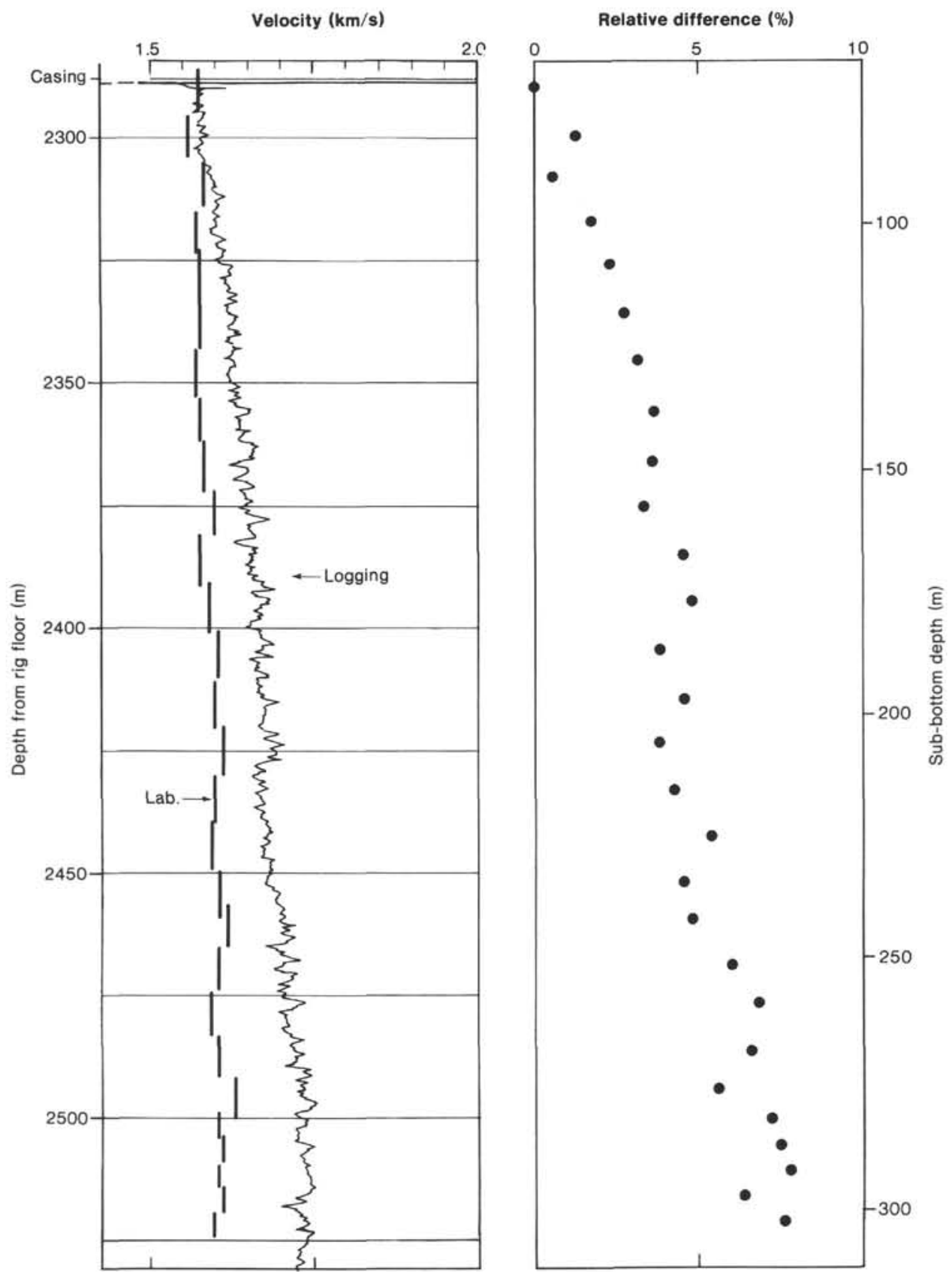

Figure 13. Variations of compressional wave velocities from shipboard measurements and velocity logs with depth at Site 586. Relative differences between these as a function of depth are shown at the right. 


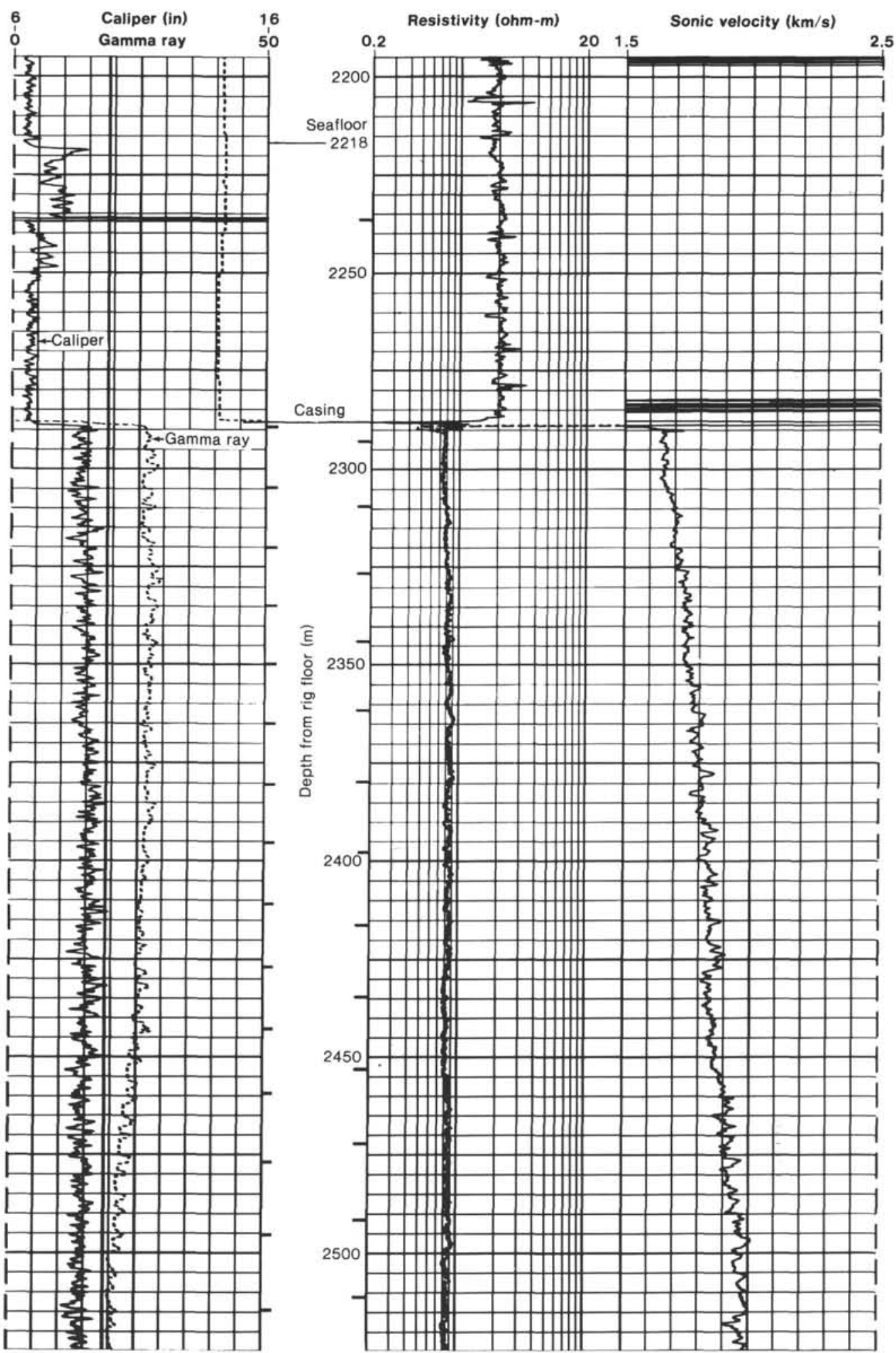

Figure 14. Logging results, Hole 586C, showing caliper, gamma-ray, resistivity, and sonic velocity. 


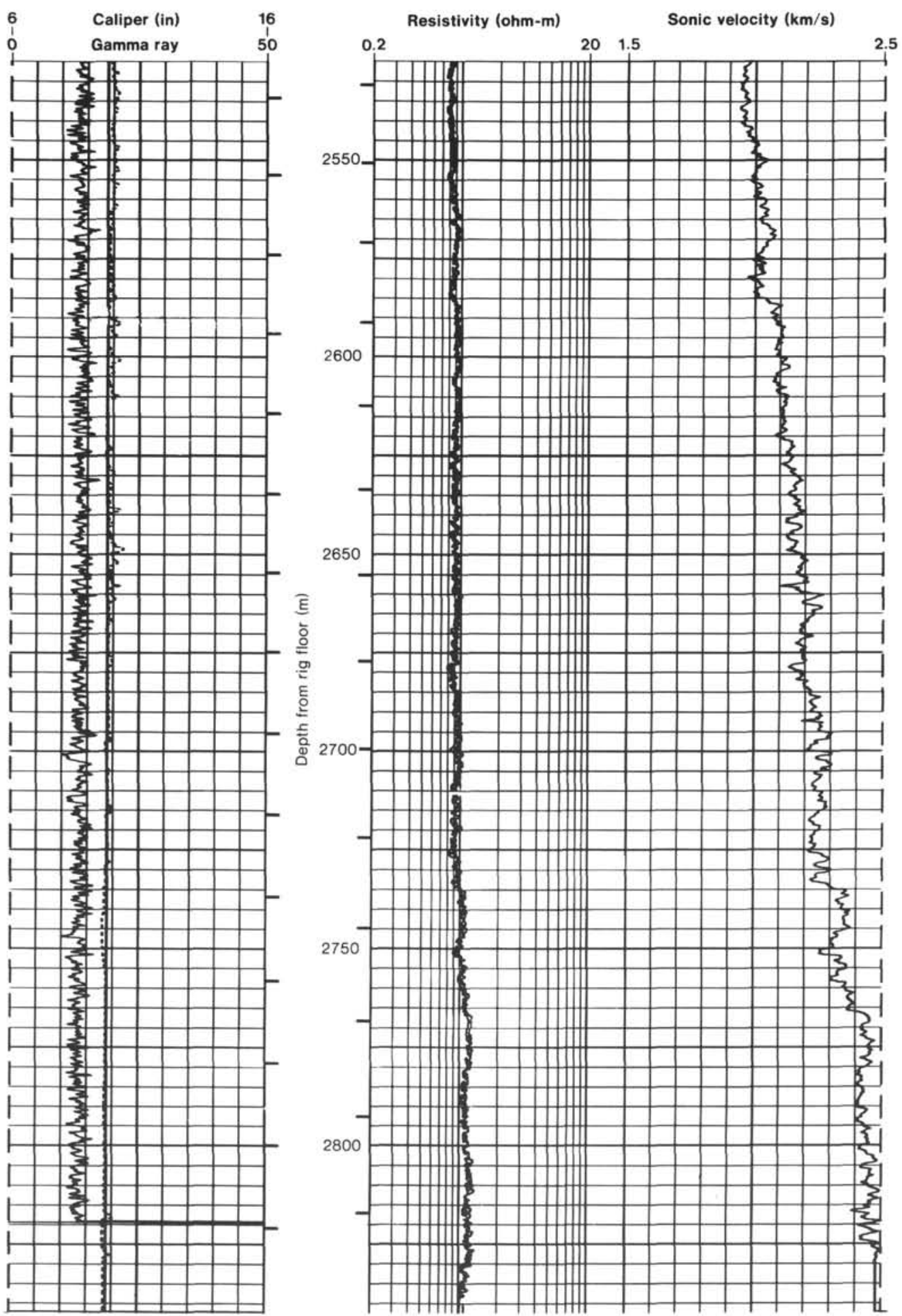

Figure 14. (Continued). 


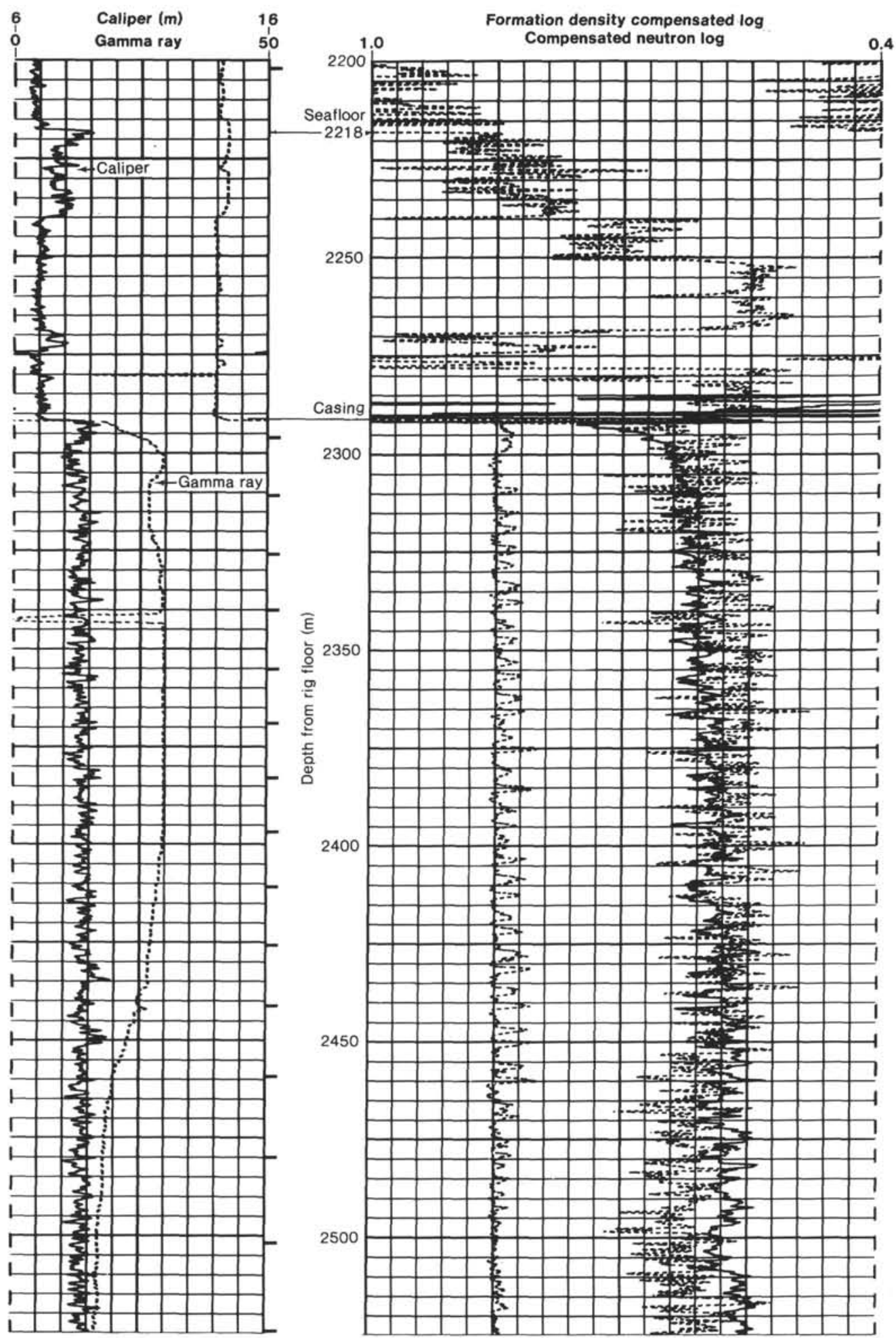

Figure 15 . Logging results, Hole 586C, showing caliper, gamma-ray, formation density compensated log, and compensated neutron log. 

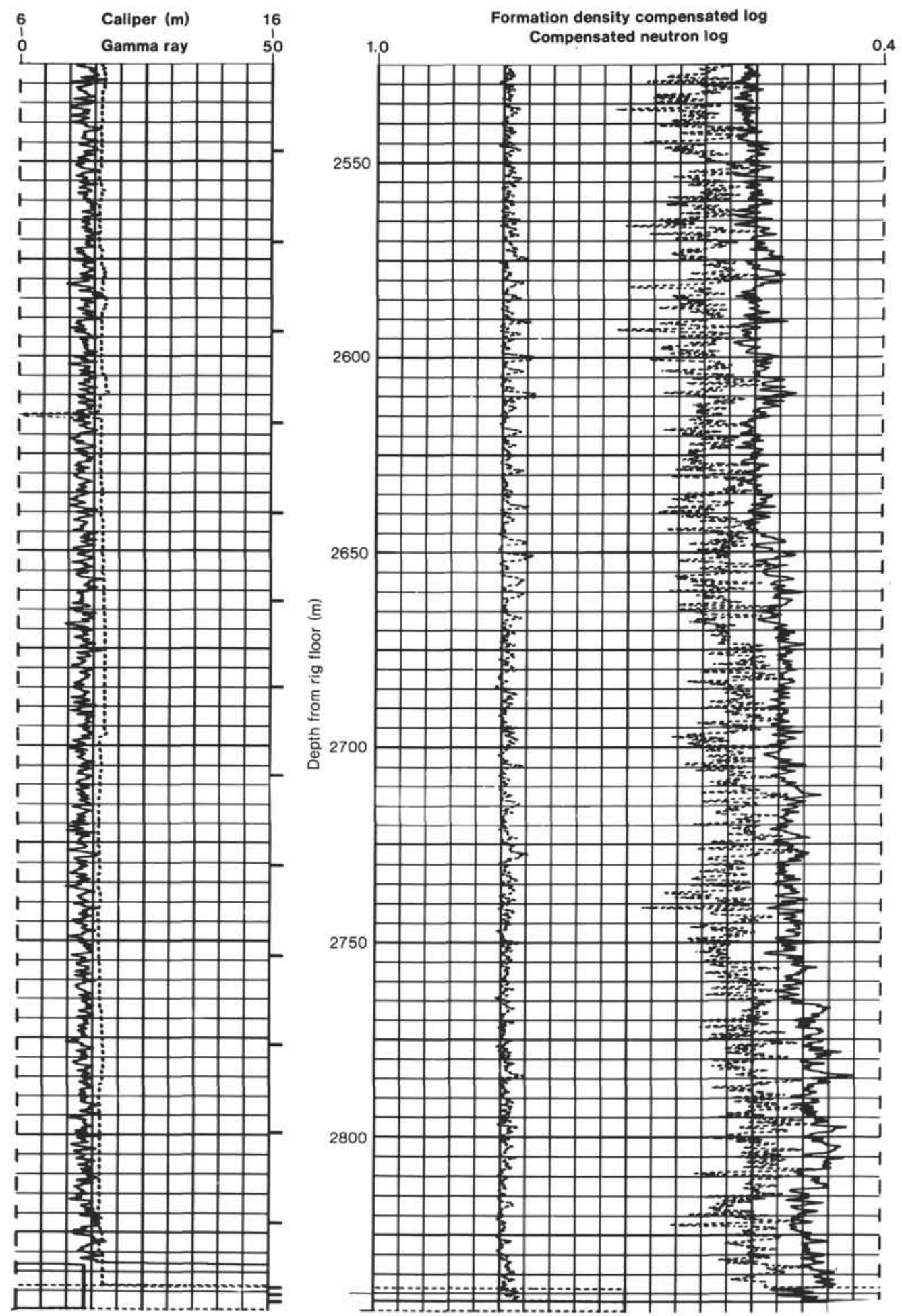

Figure 15. (Continued). 


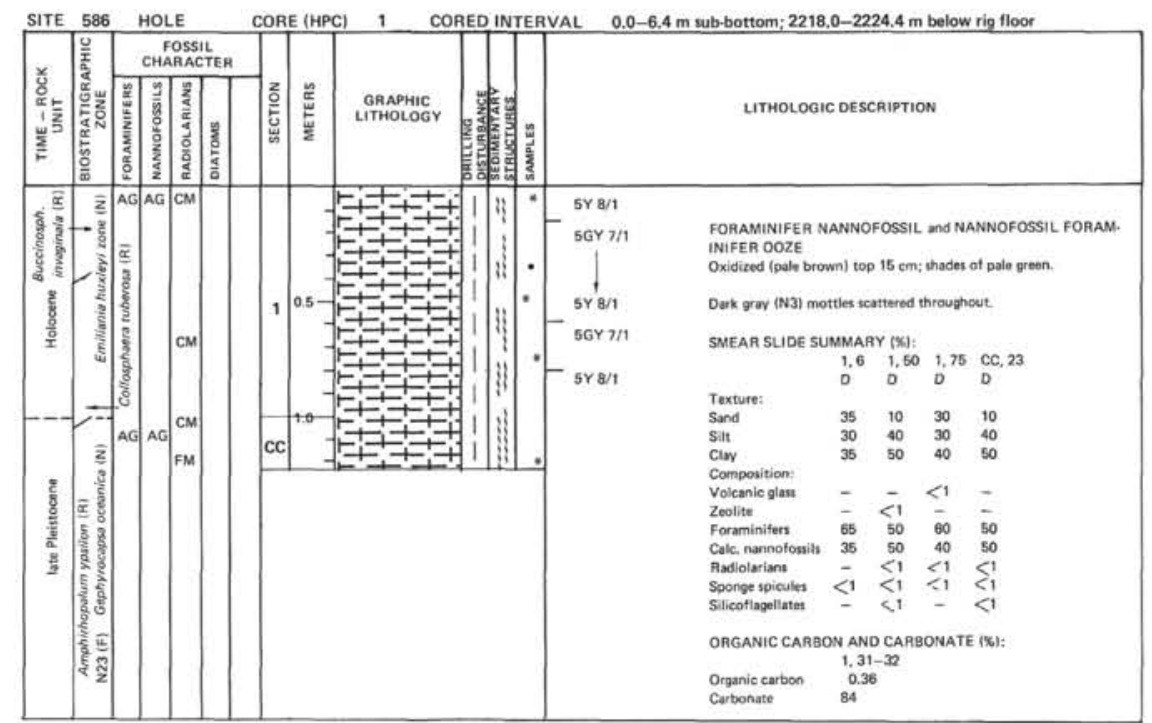

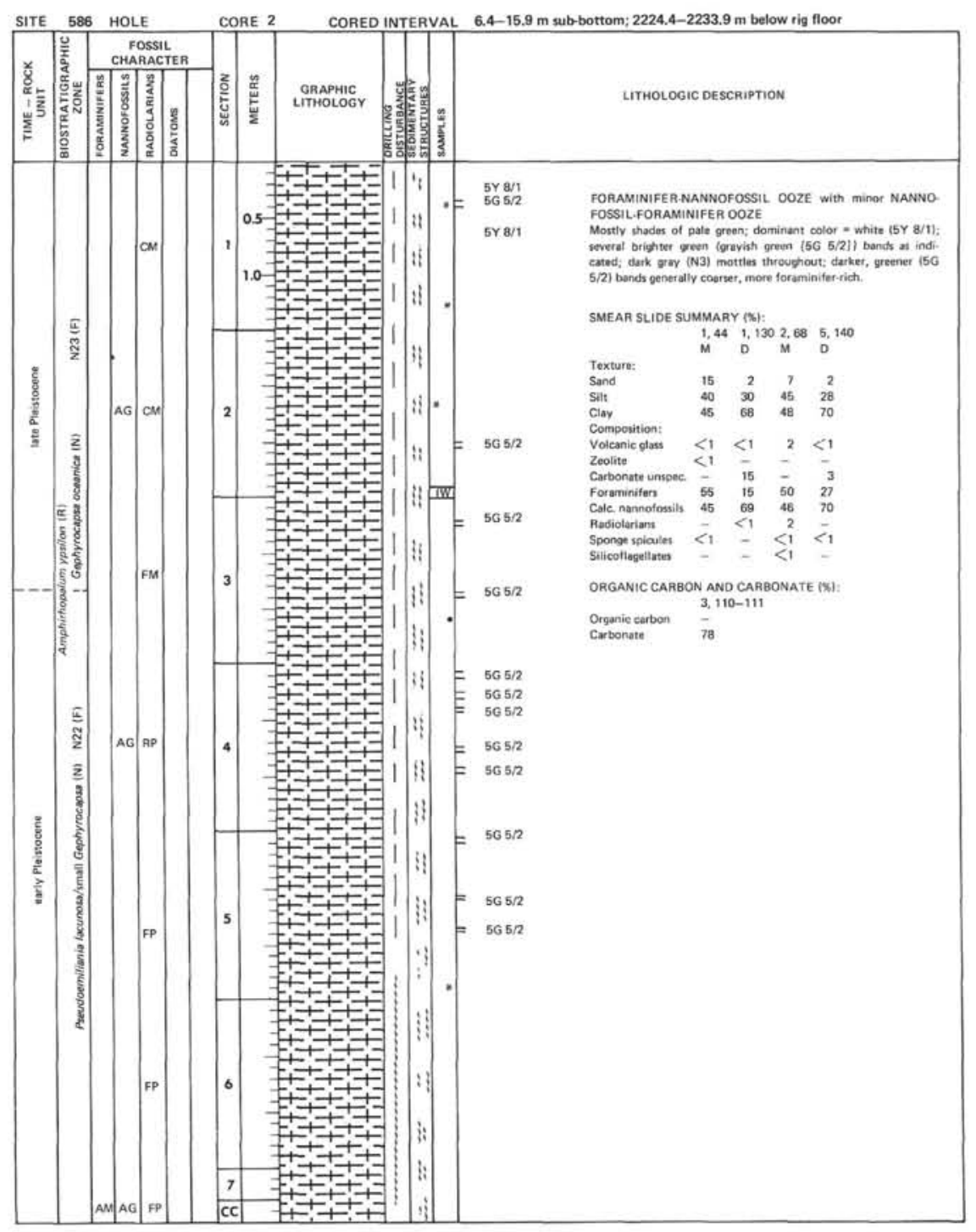

Information on core description sheets, for ALL sites, represents field notes taken aboard ship under time pressure. Some of this information has been refined in accord with postwith subsequent findings. Thus the reader should be alerted to the occasional ambiguity or discrepancy. 

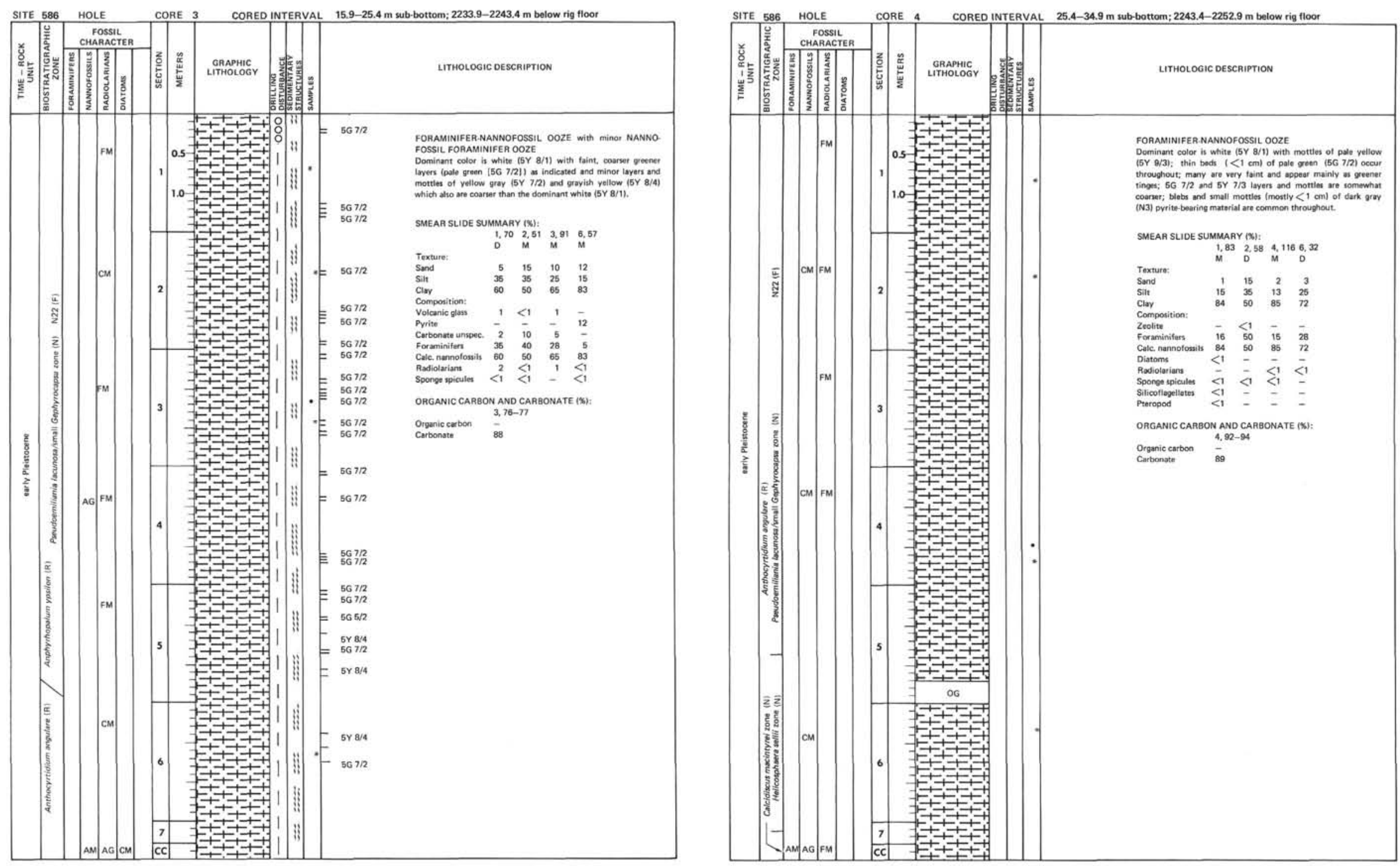


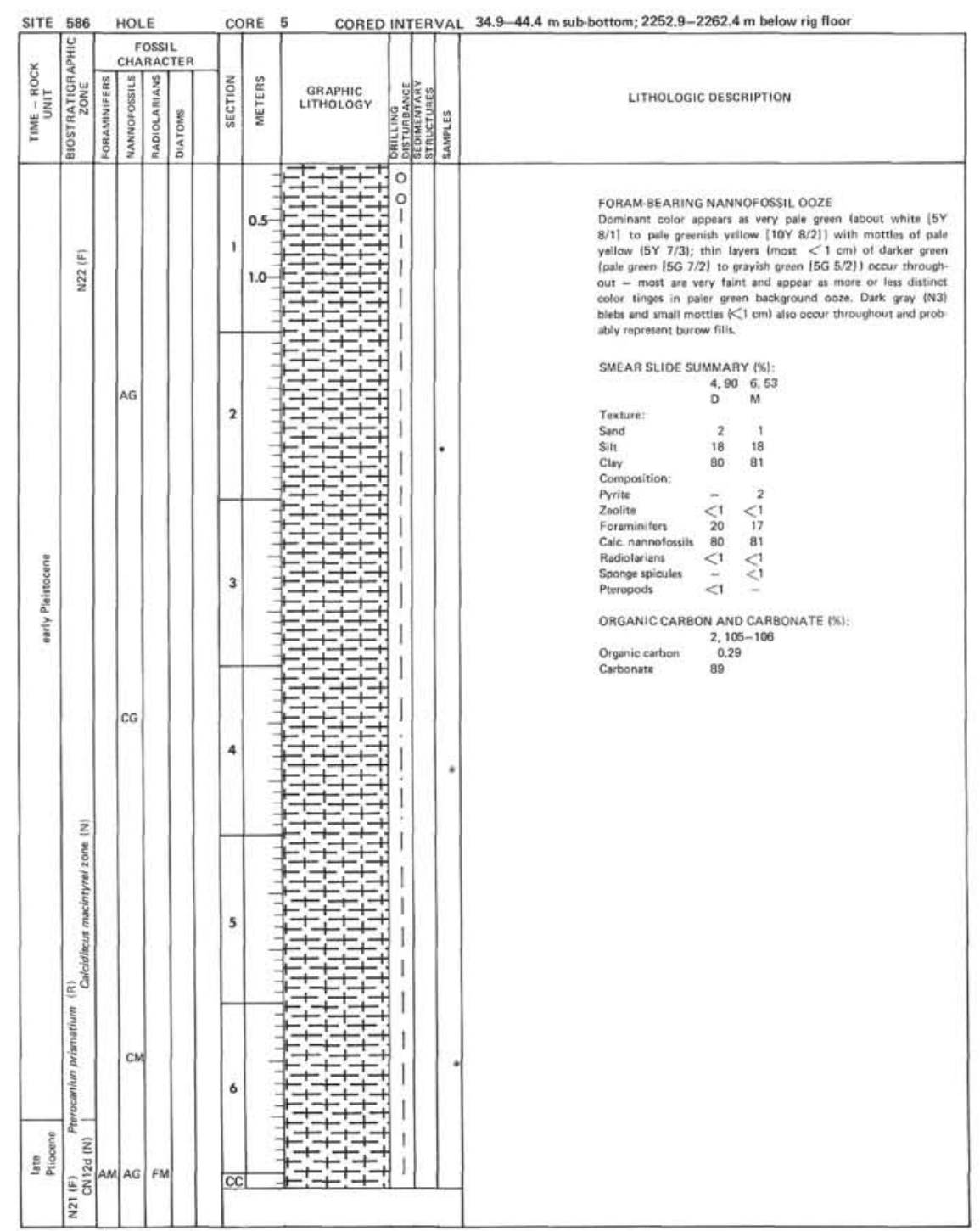



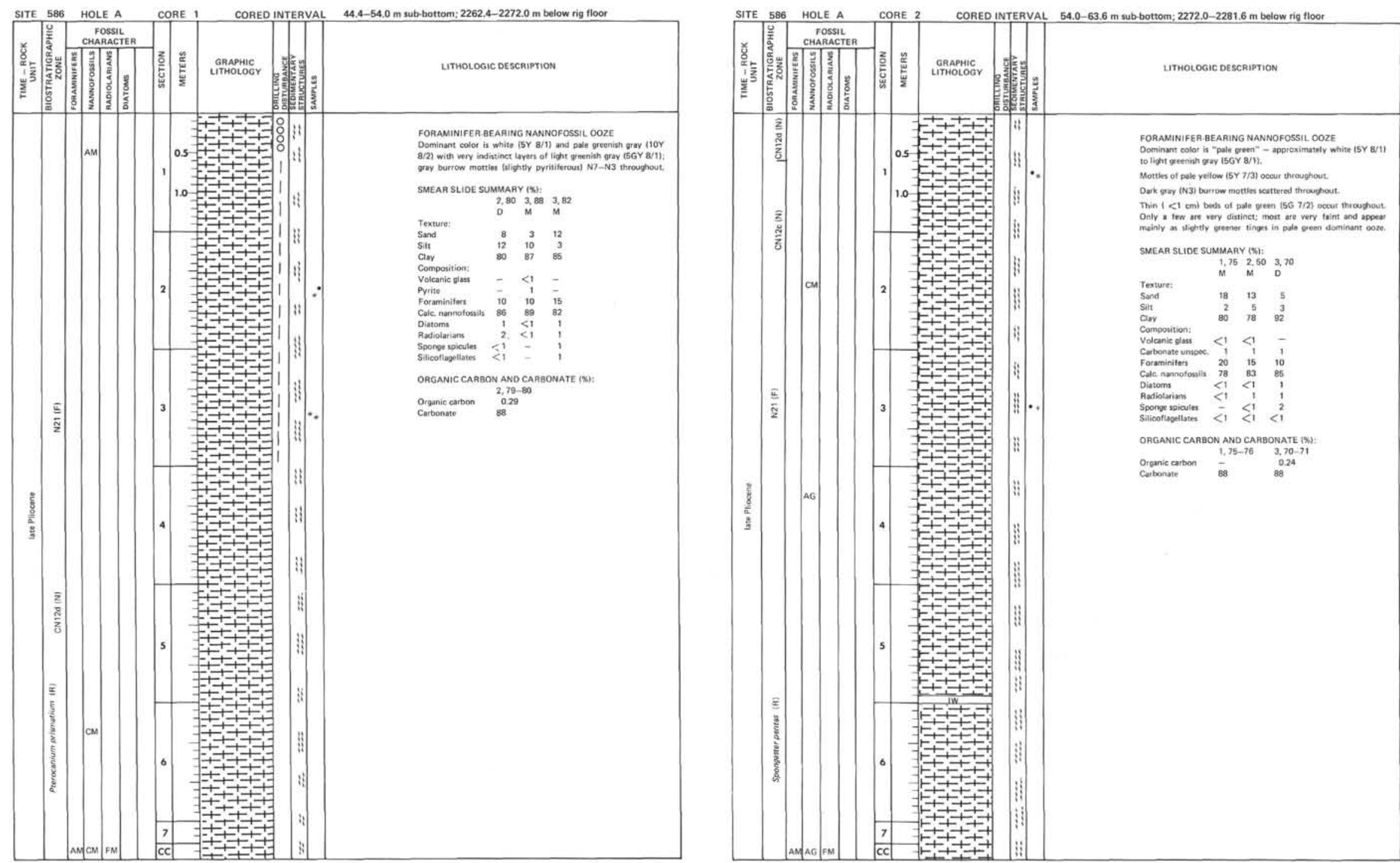


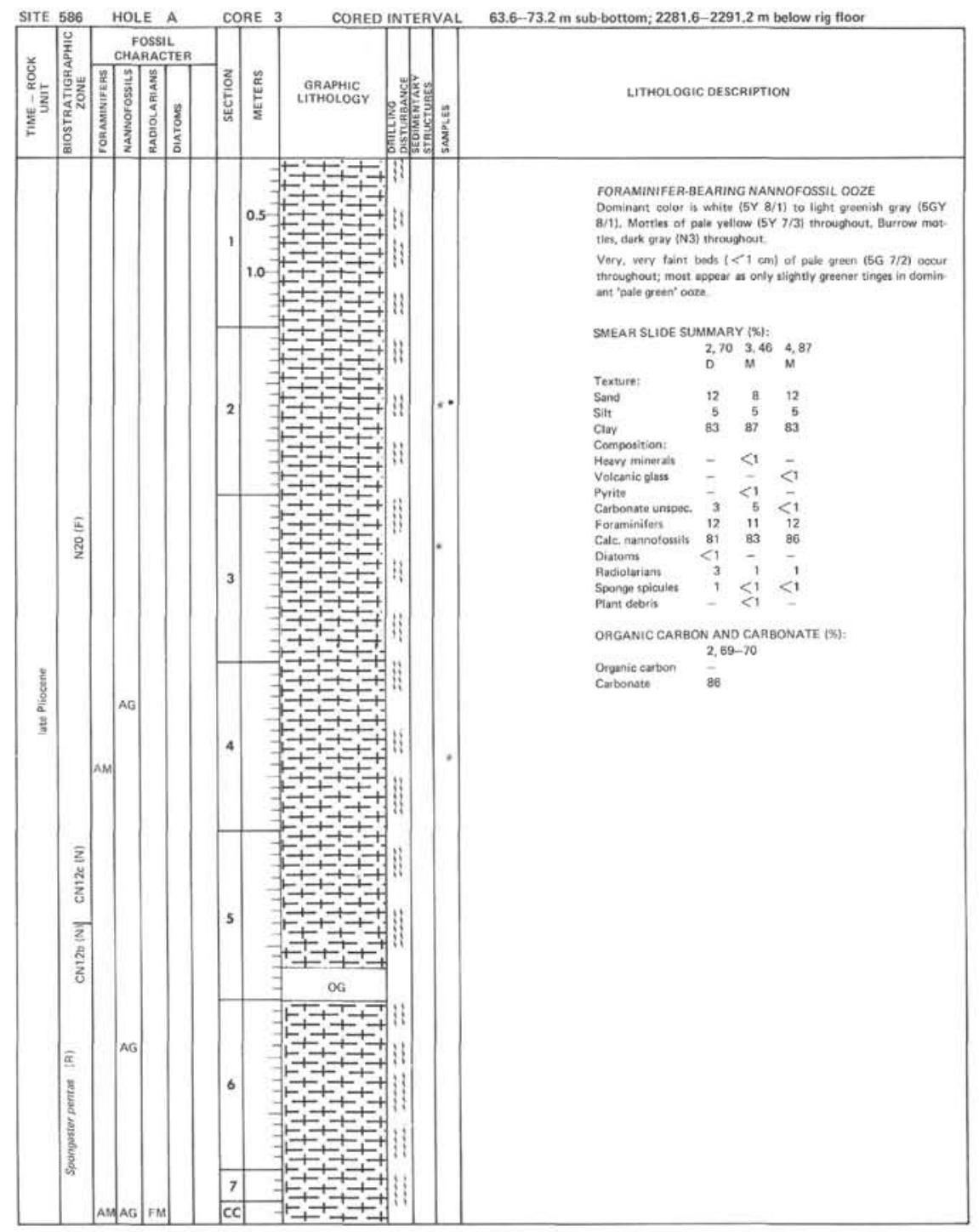

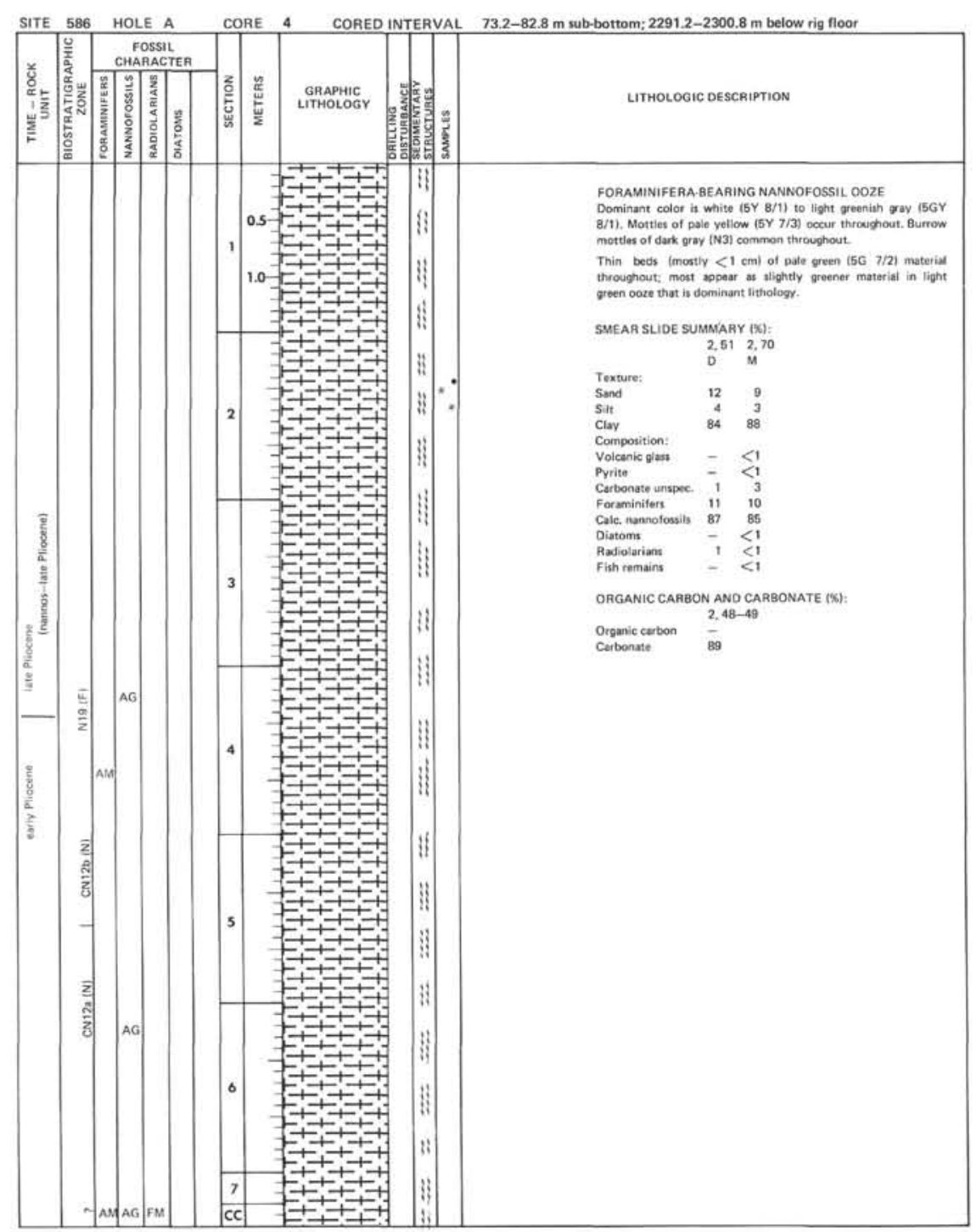



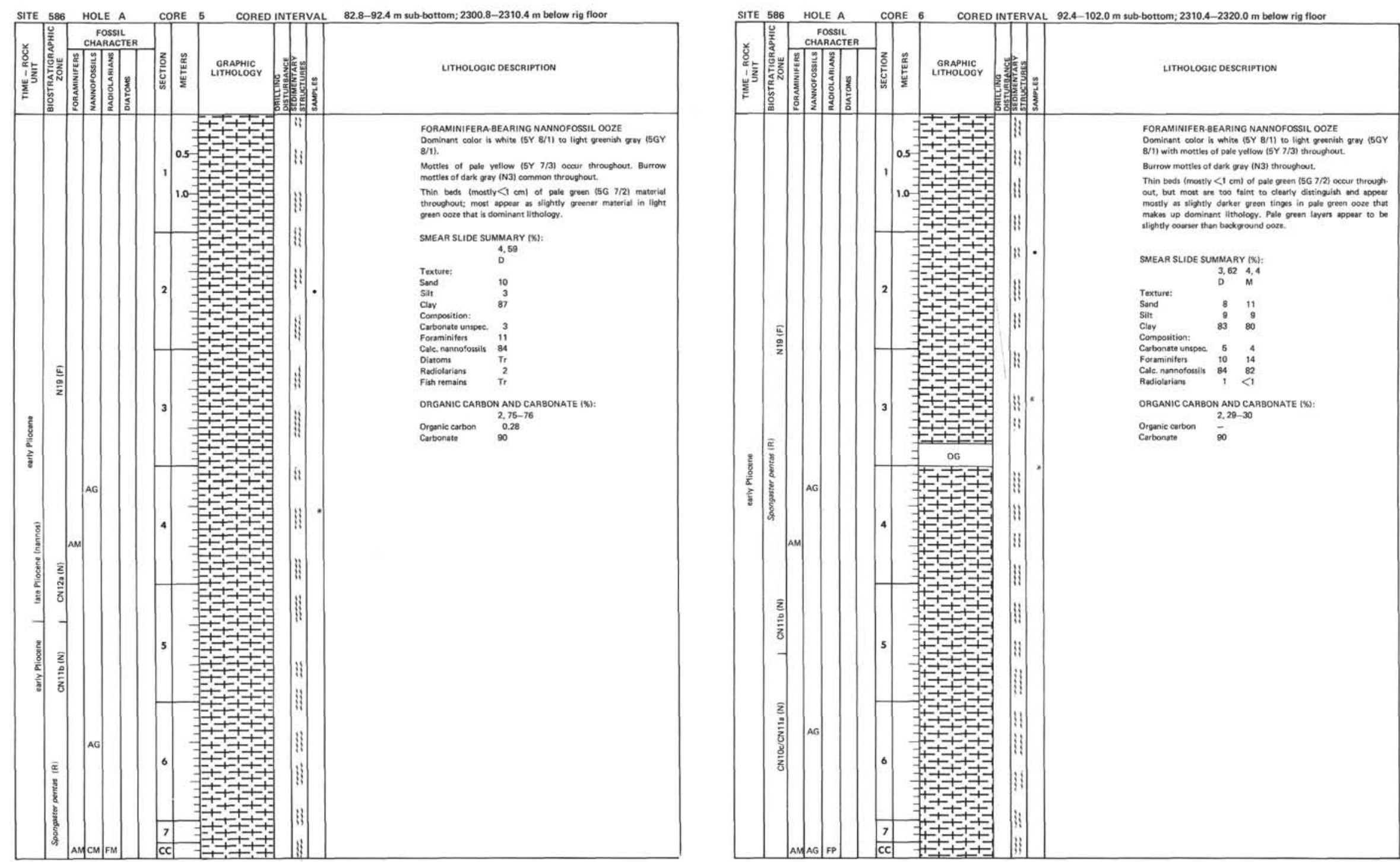

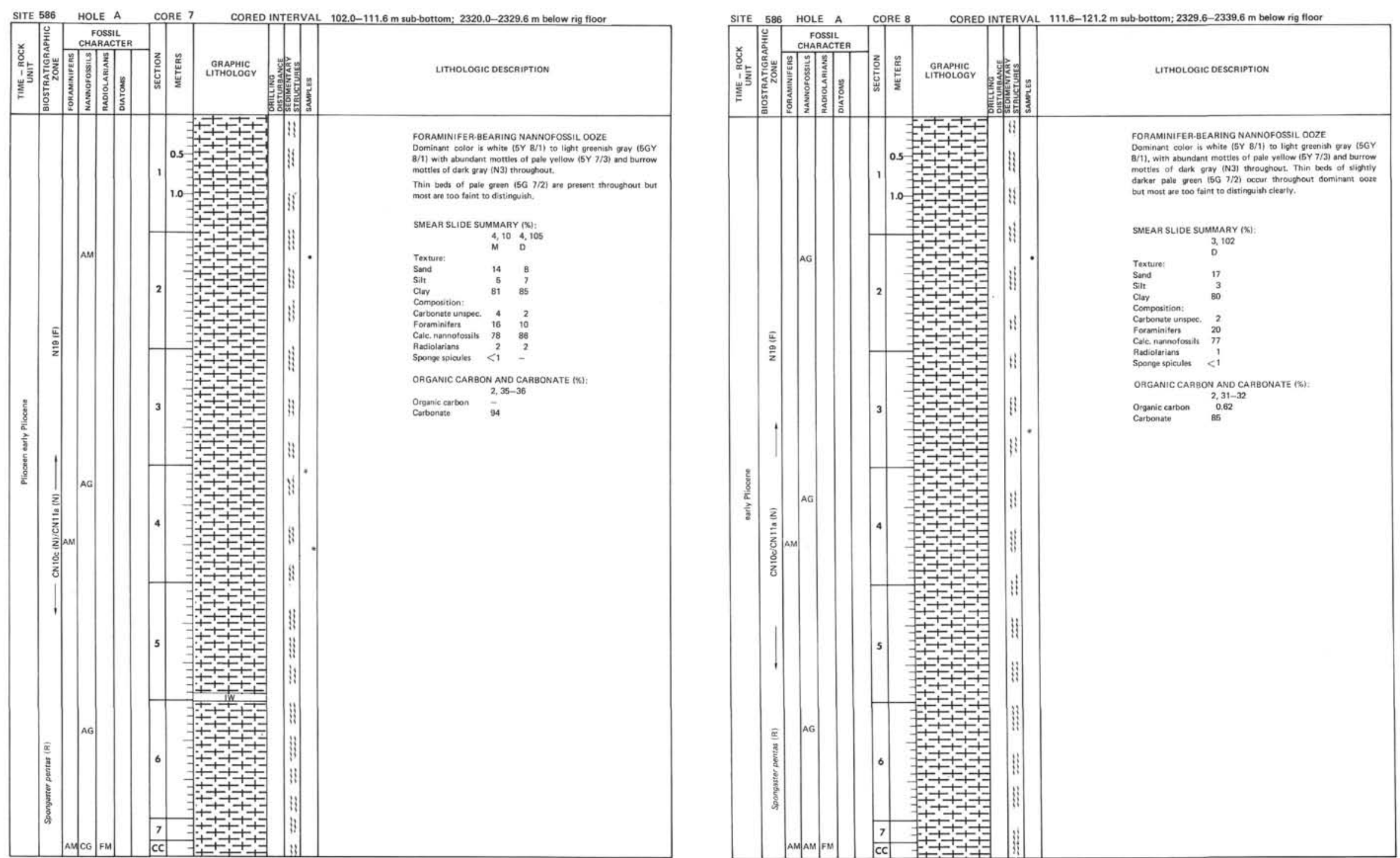

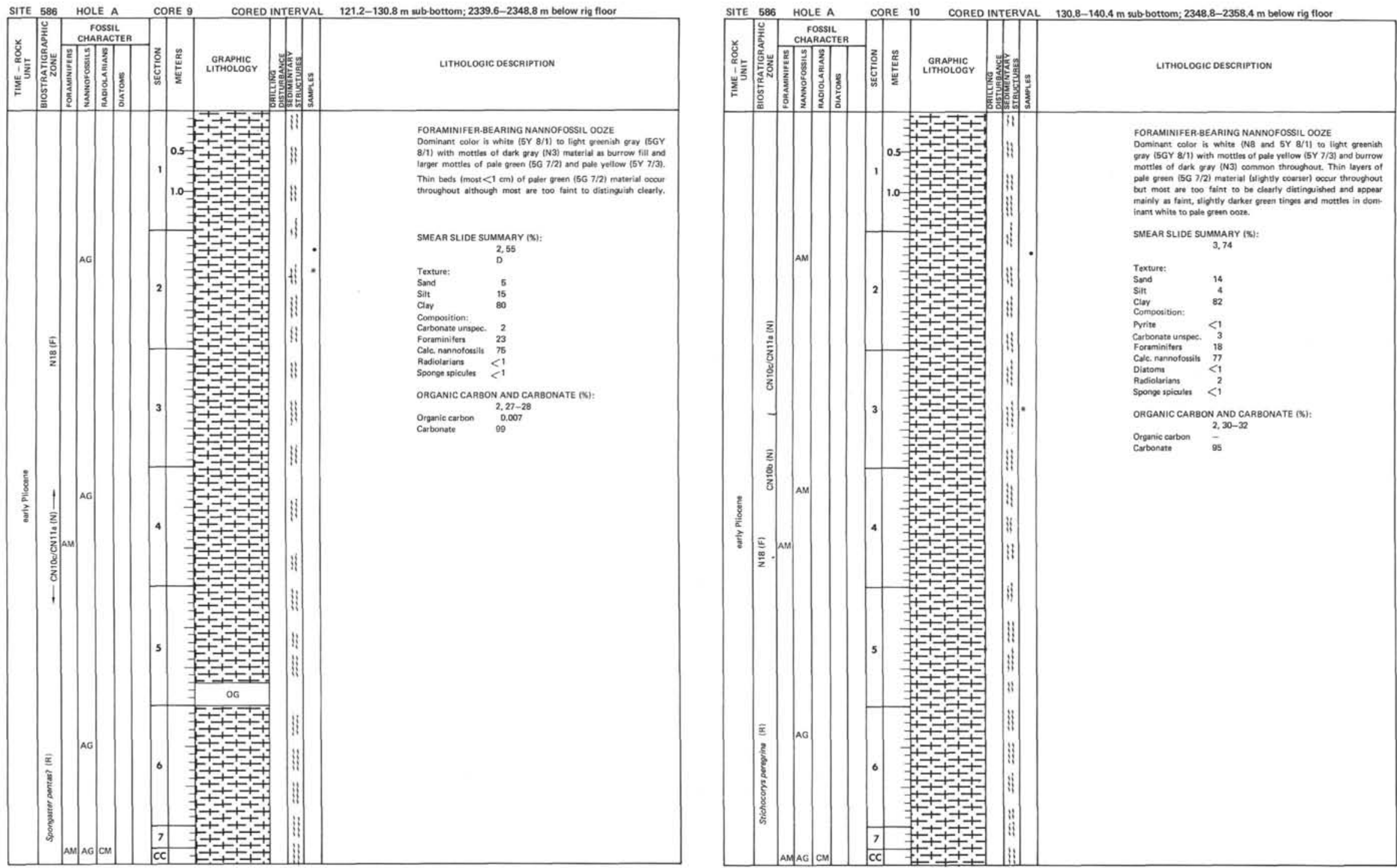


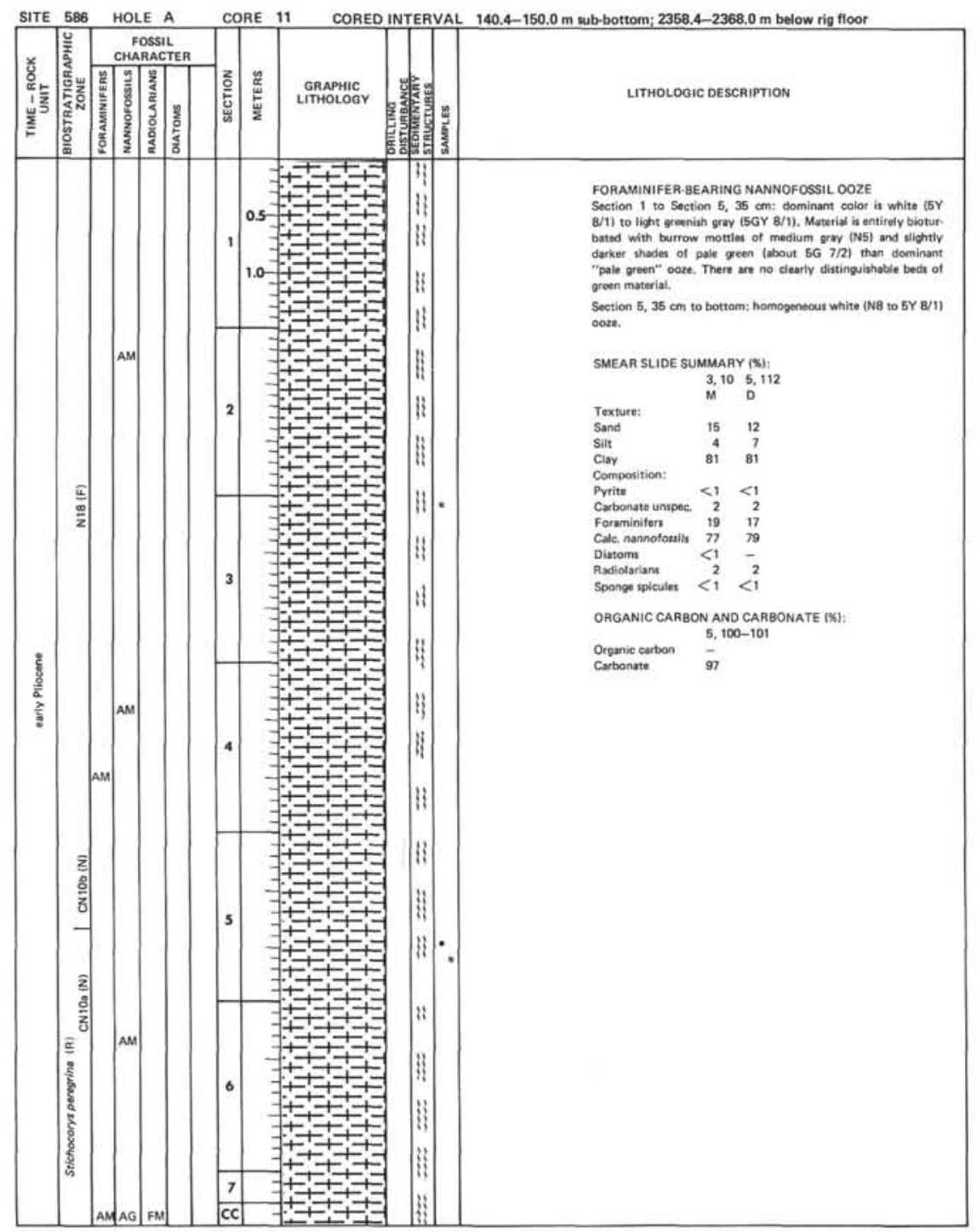

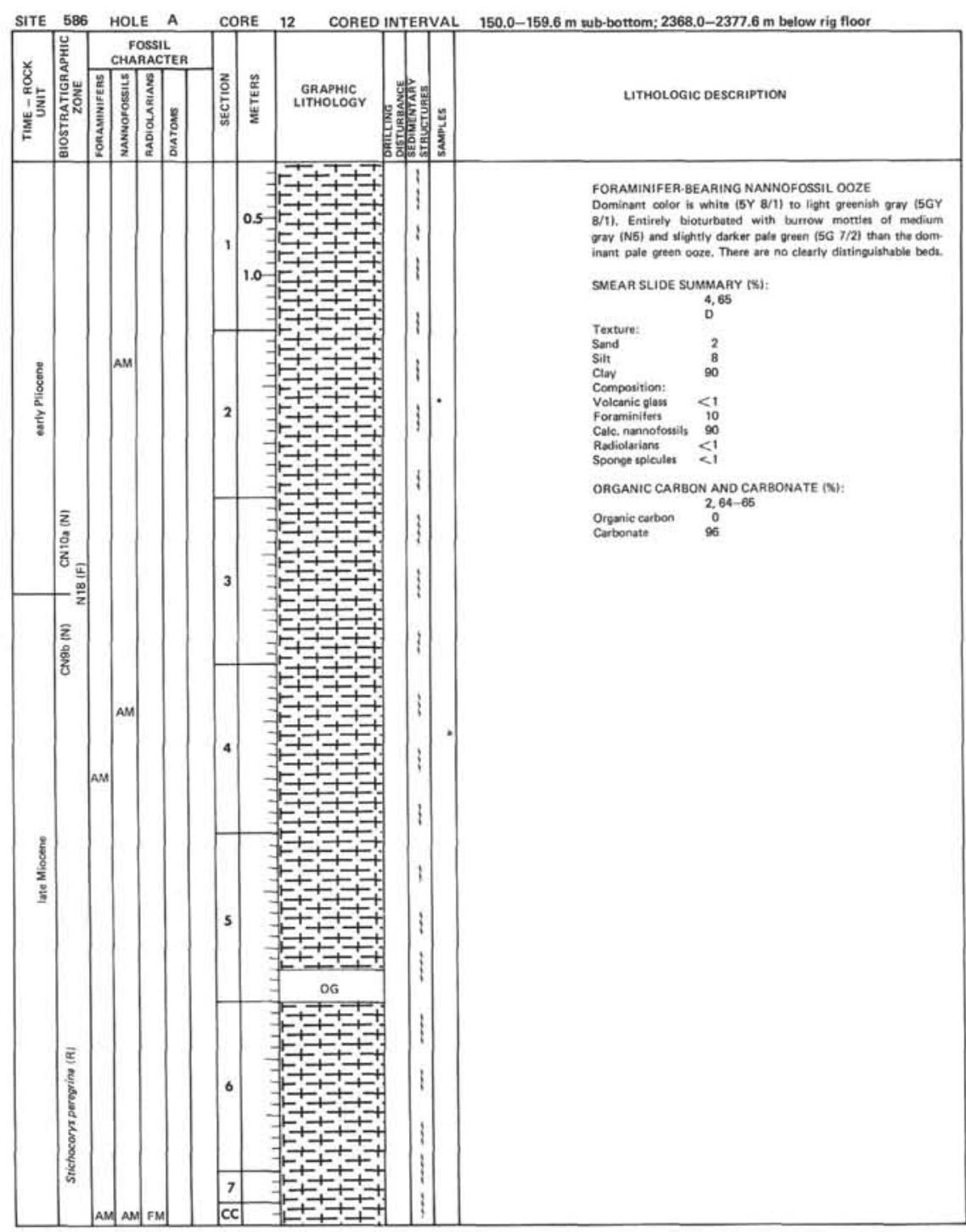



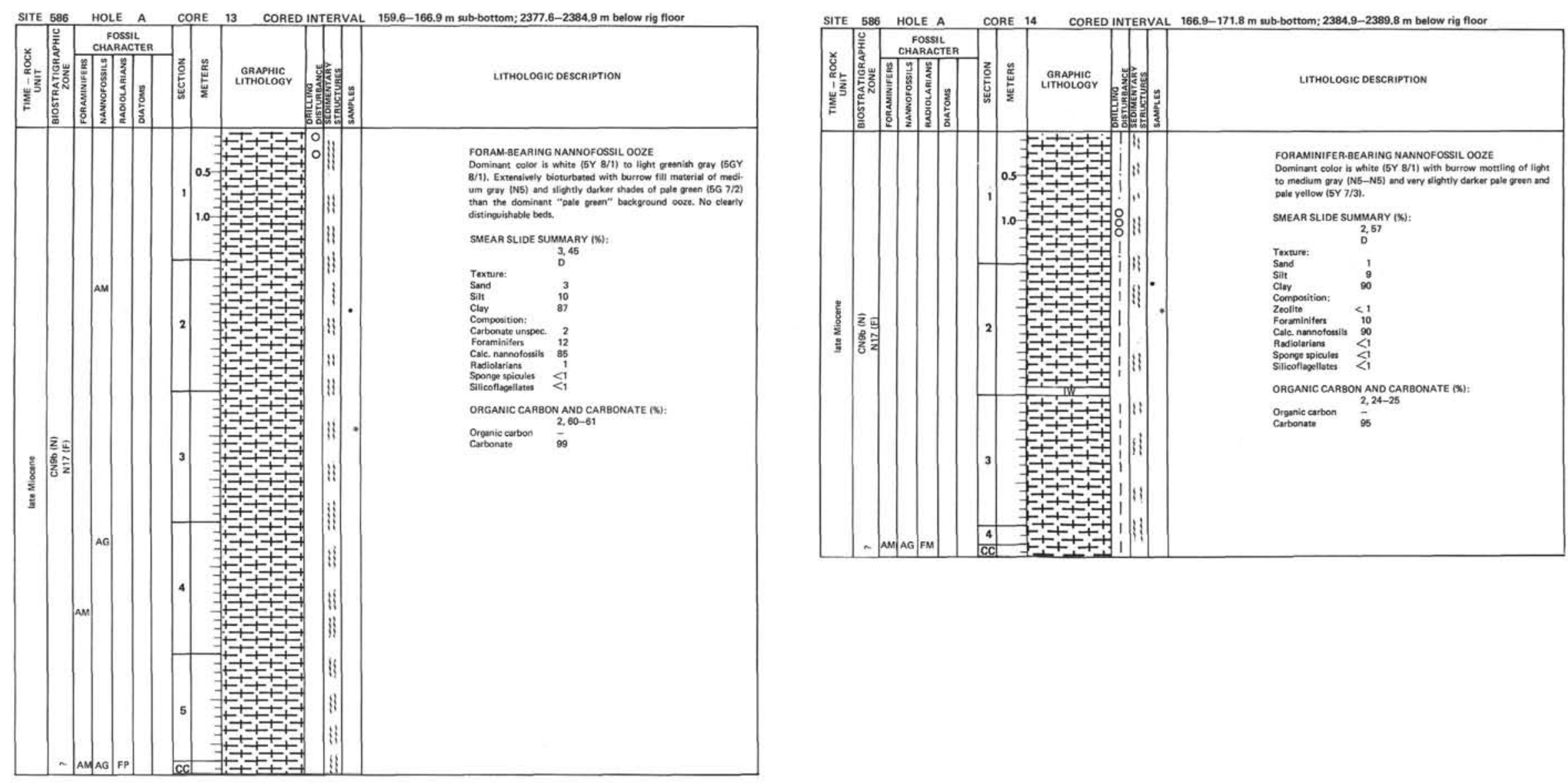

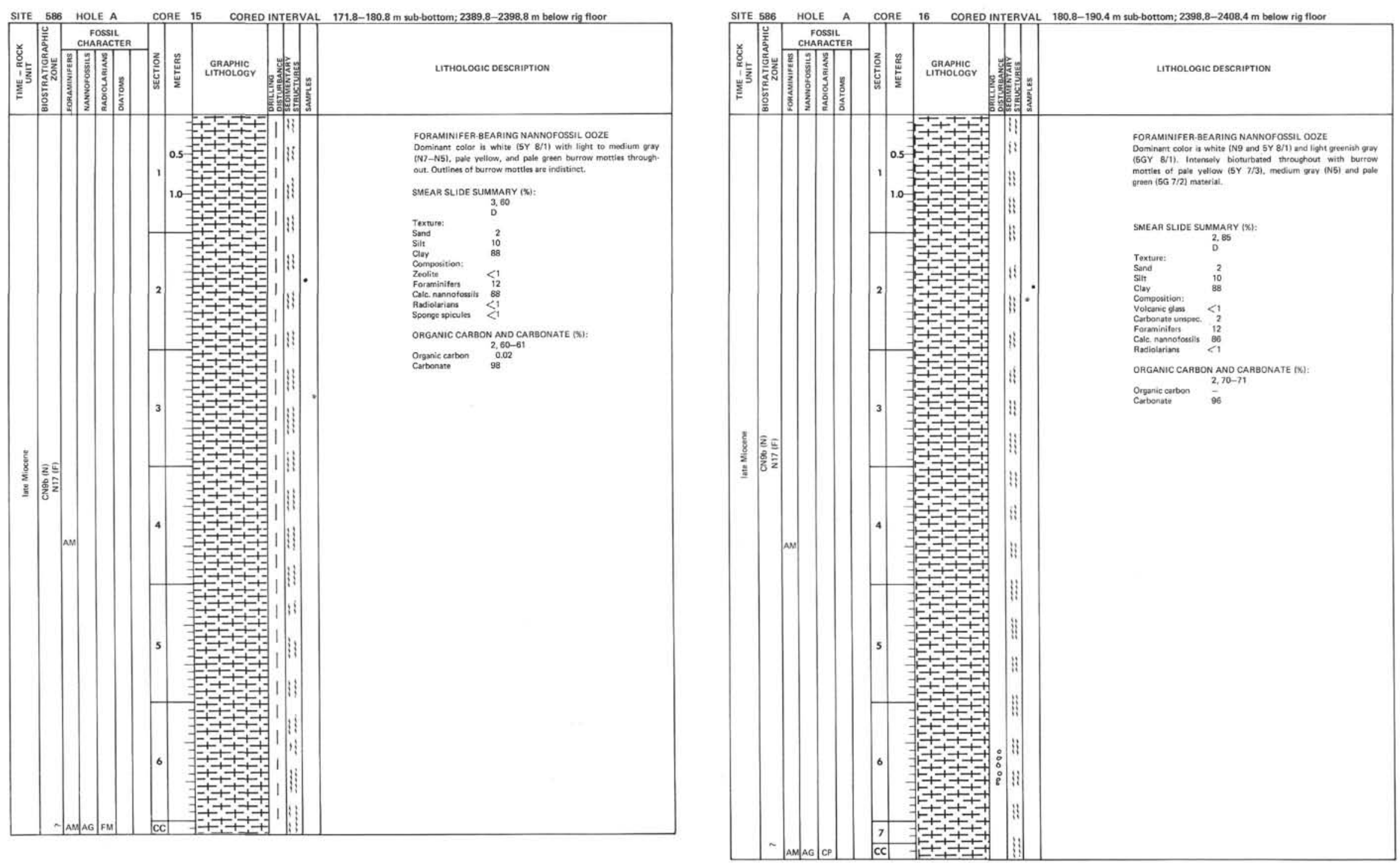

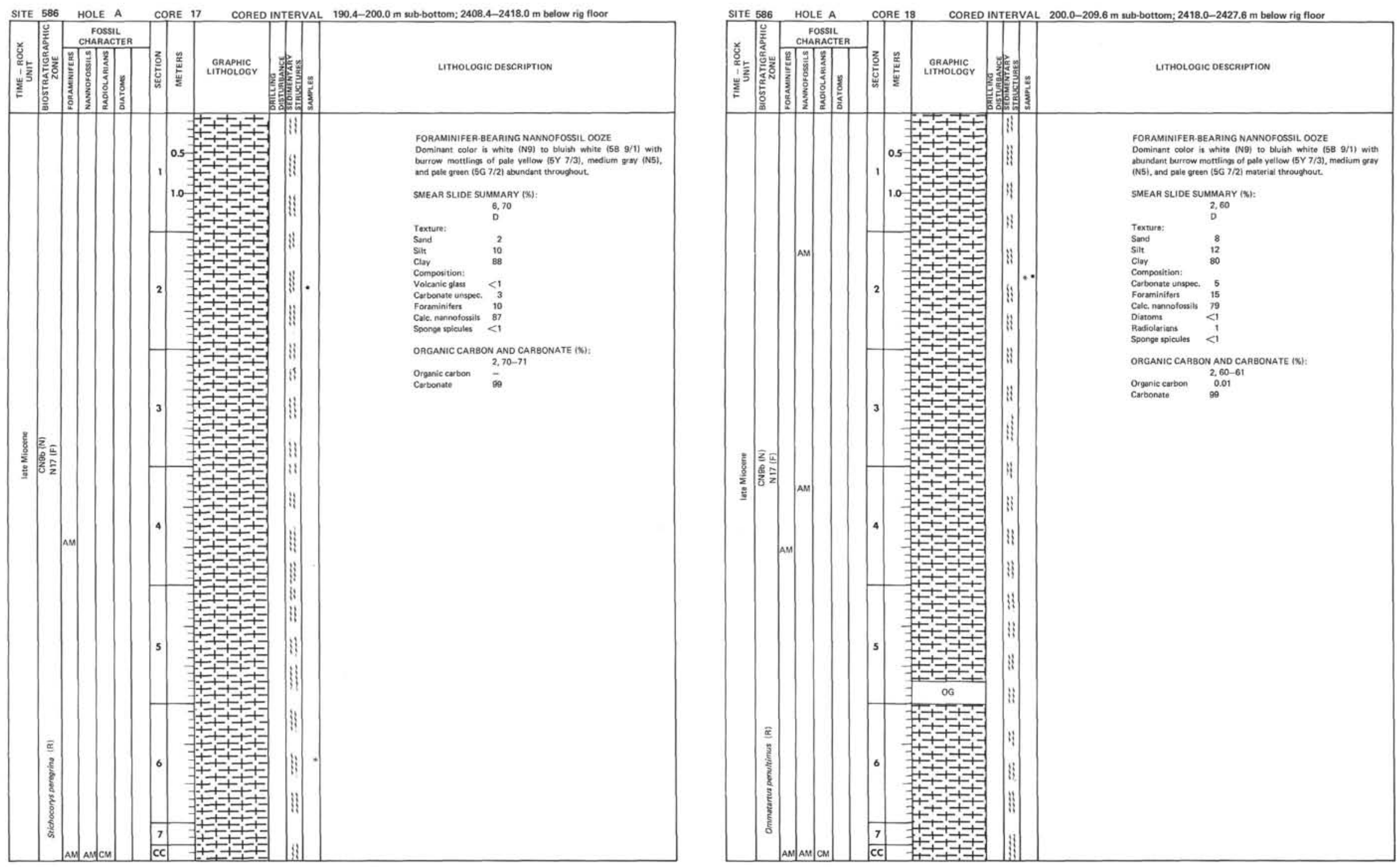

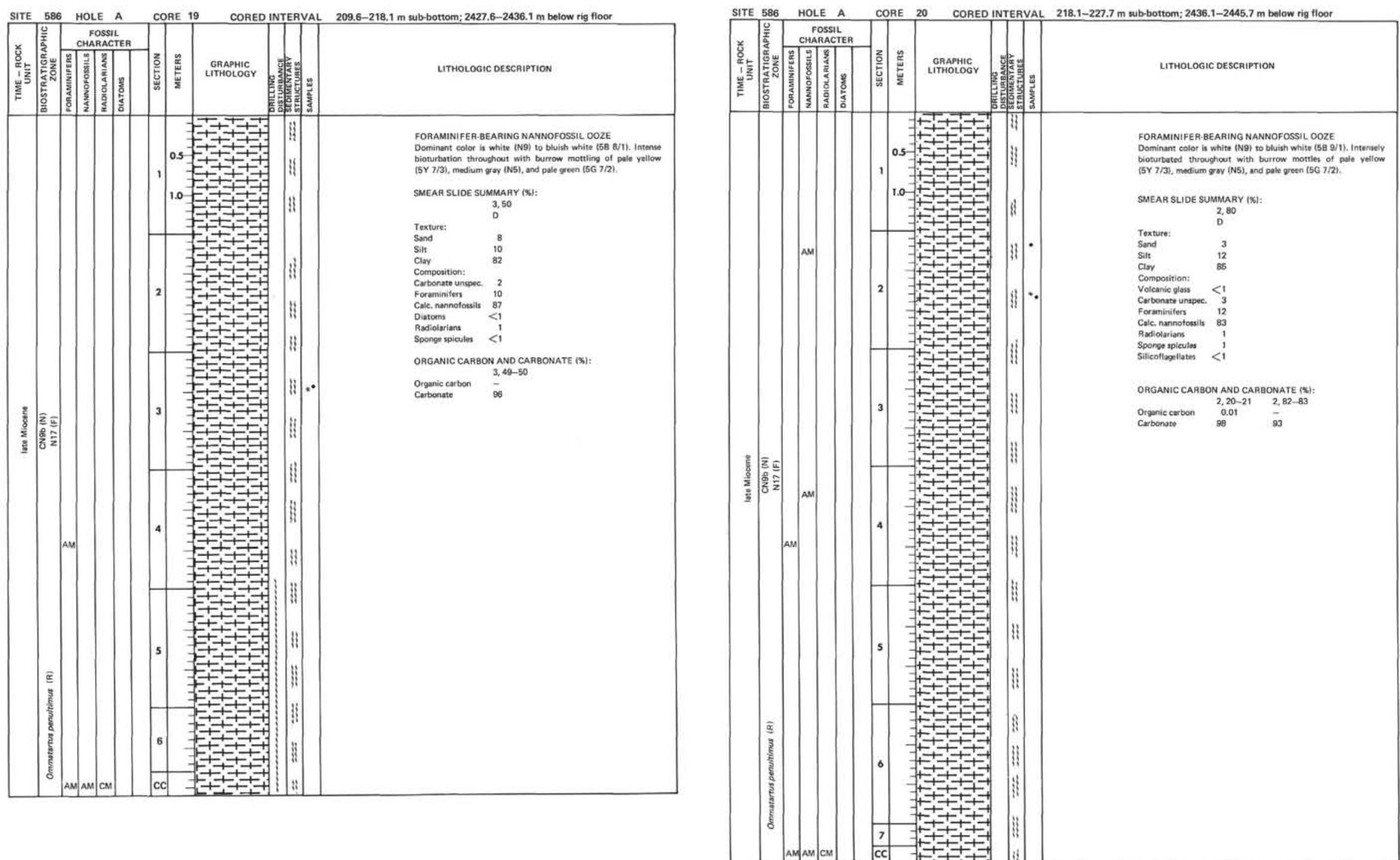

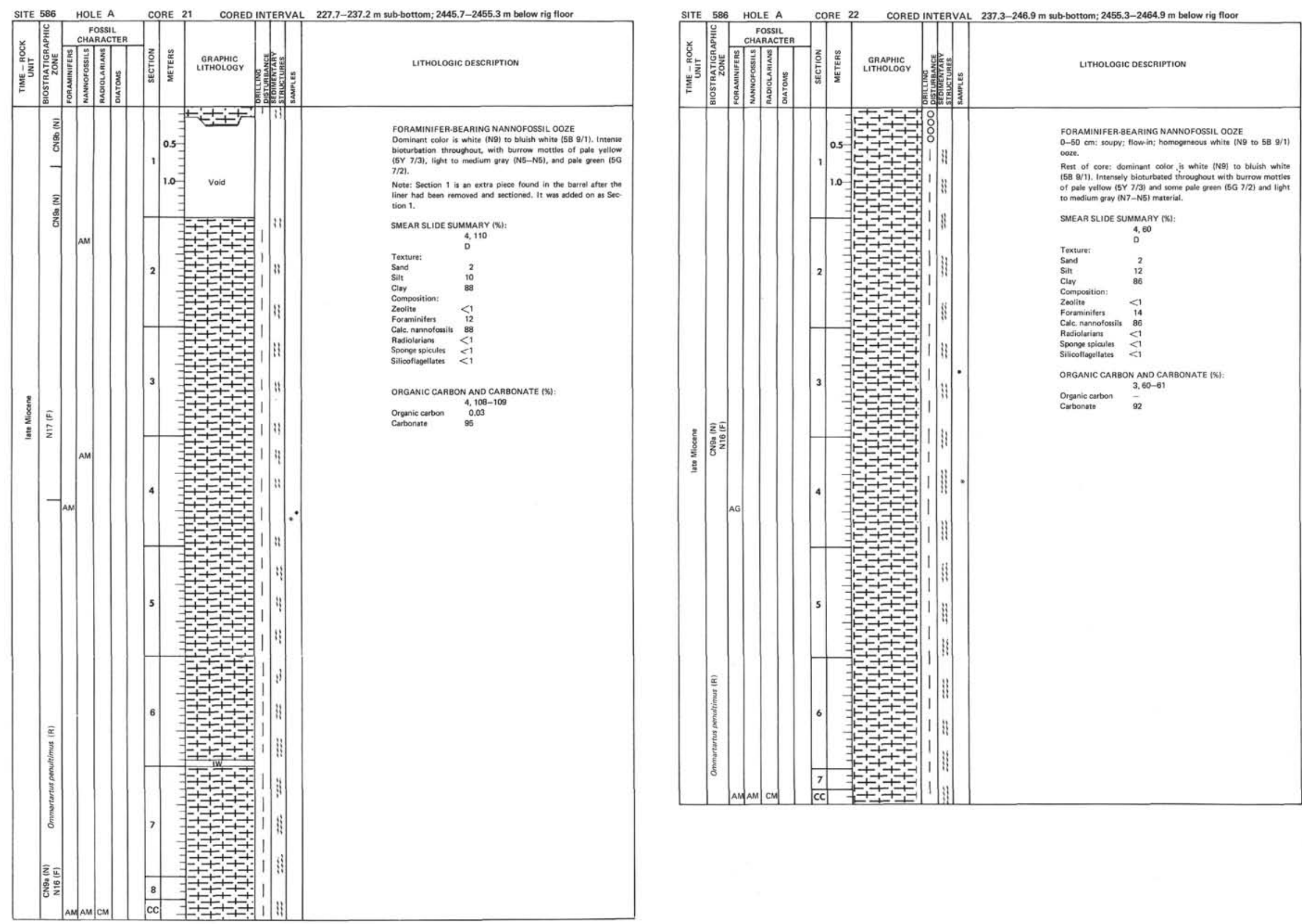
ని

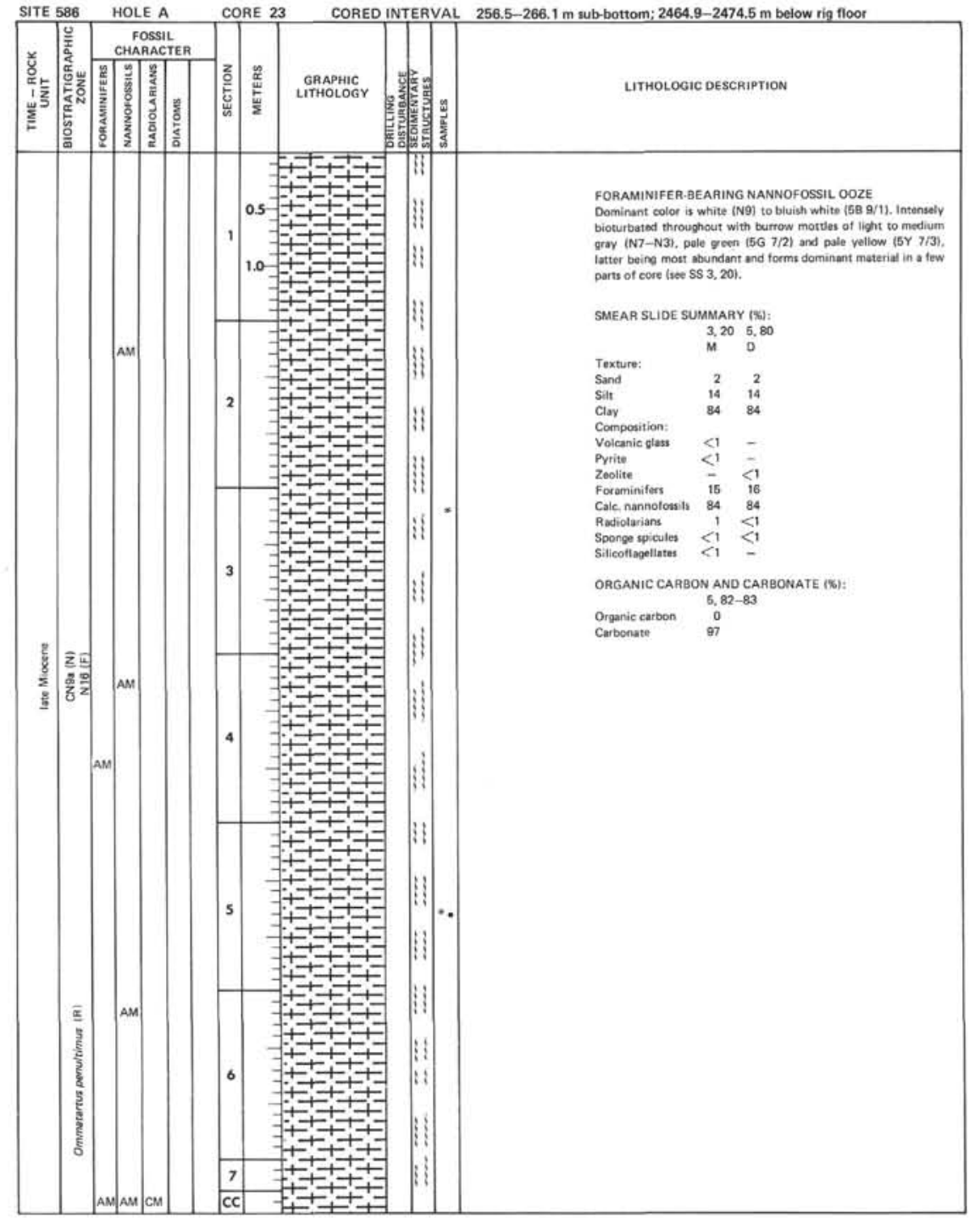

SITE 586 HOLE A CORE 24 CORED INTERVAL 256.5-266.1 m sub-bottom; 2474.5-2484.1 m below rig floor

\begin{tabular}{|c|c|c|c|c|c|c|}
\hline & & 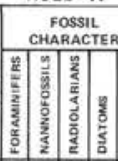 & 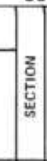 & $\begin{array}{l}\text { GRAPHIC } \\
\text { LITHOLOGY }\end{array}$ & 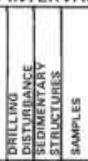 & LITHOLOGIC DESCRIPTION \\
\hline 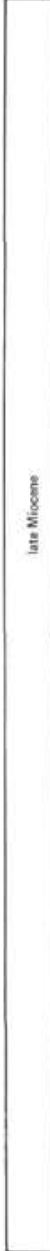 & $\begin{array}{l}\frac{\mathrm{z}}{\mathrm{a}} \\
\frac{\mathrm{a}}{\mathrm{z}} \\
\frac{\mathrm{z}}{\mathrm{z}} \\
\frac{\mathrm{a}}{\mathrm{d}} \\
\mathrm{d}\end{array}$ & an & cc & (1.0. & 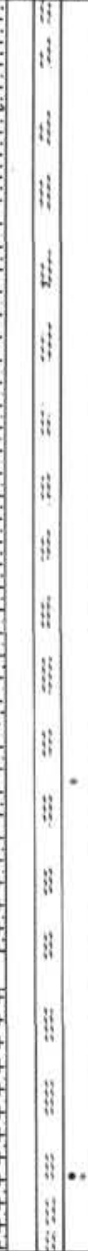 & 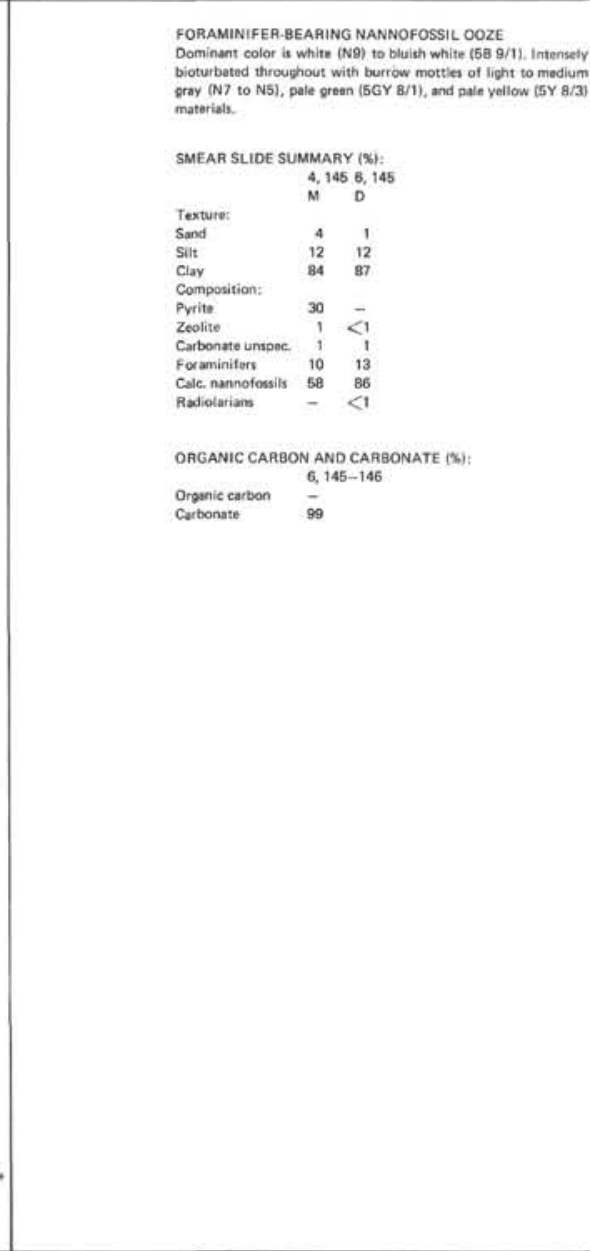 \\
\hline
\end{tabular}




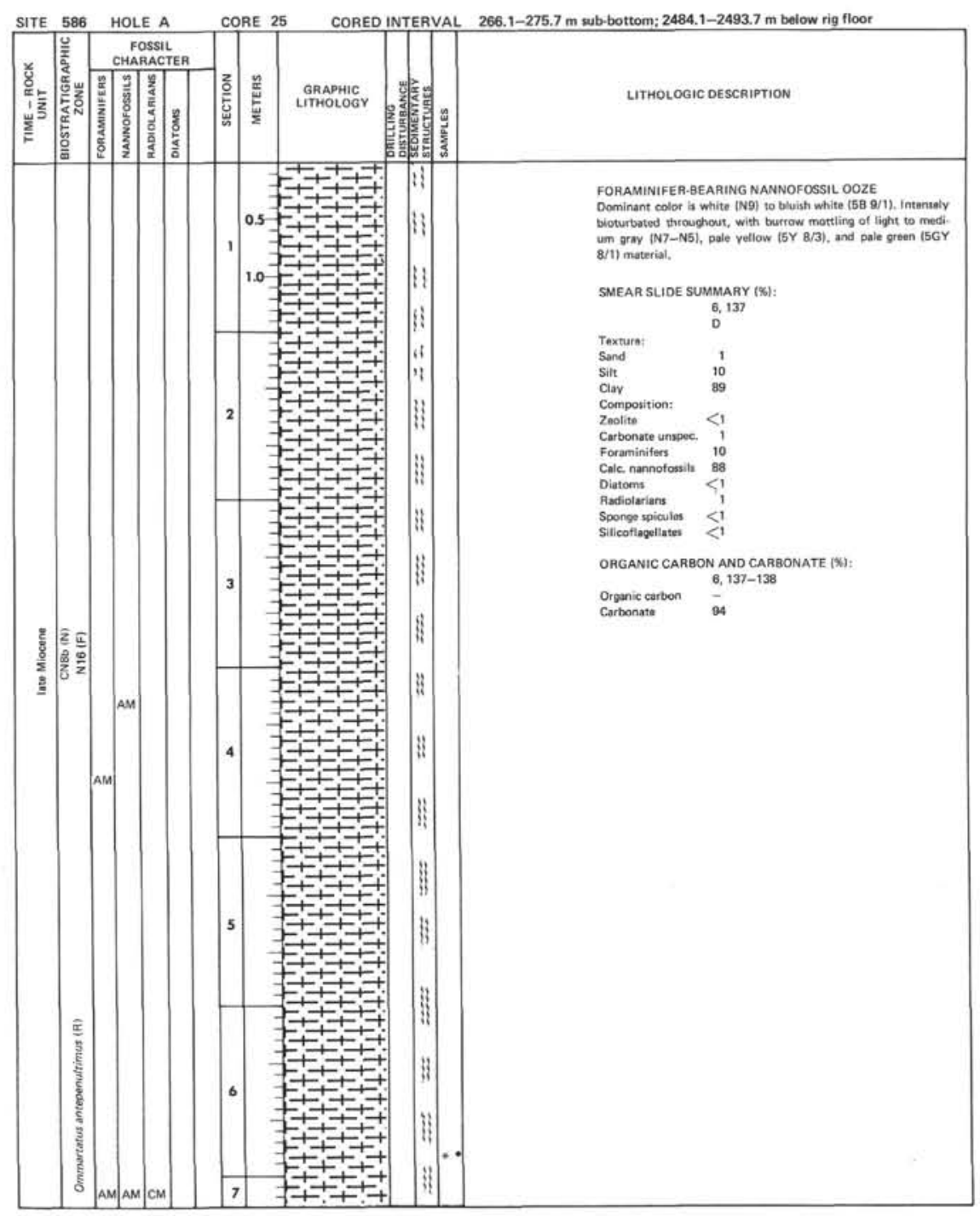

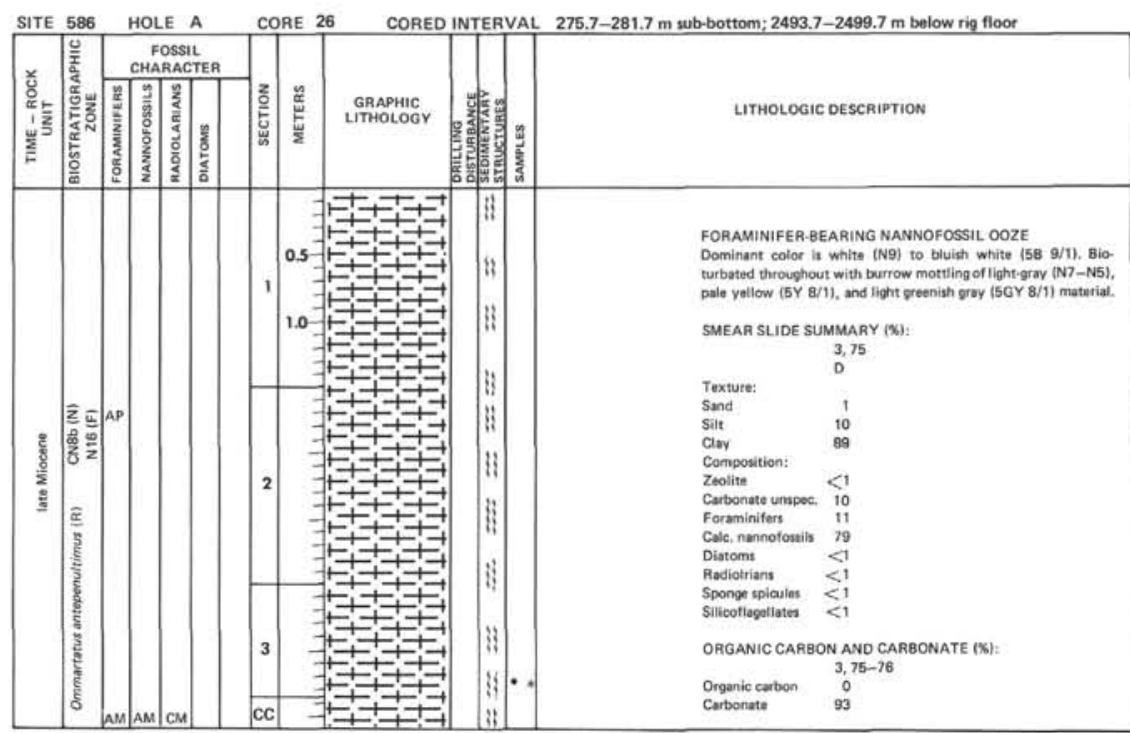

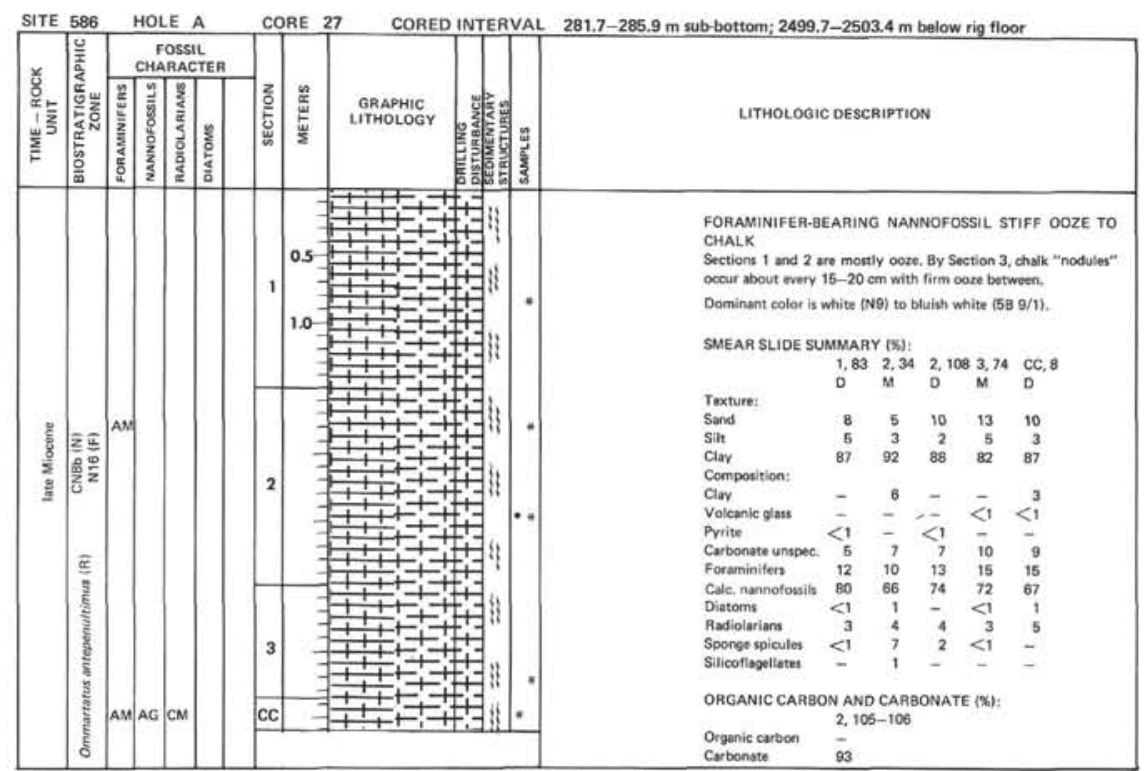




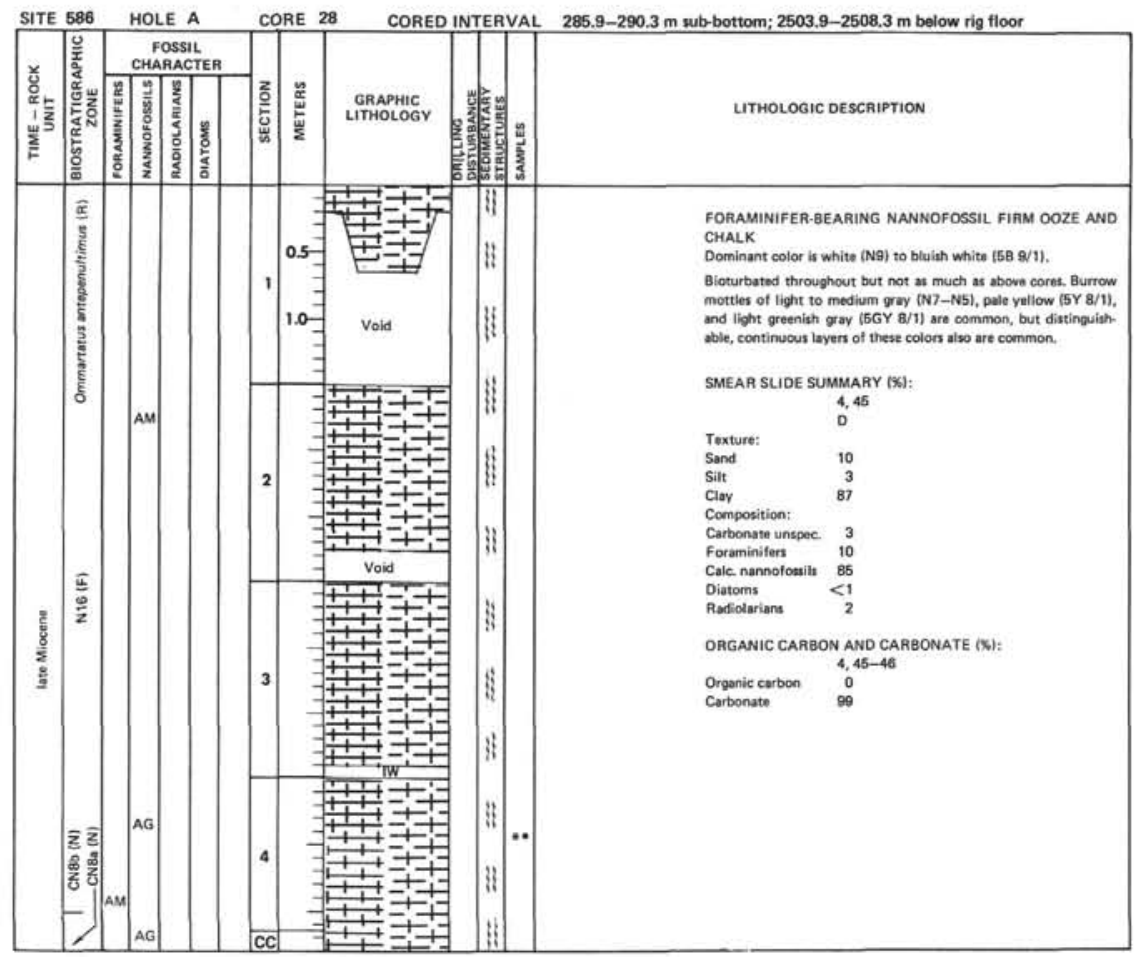

SITE 586 HOLE A CORE 29 CORED INTERVAL 290.3-295.3 m sub-bottom; 2508.3-1513.3 m below rig floor

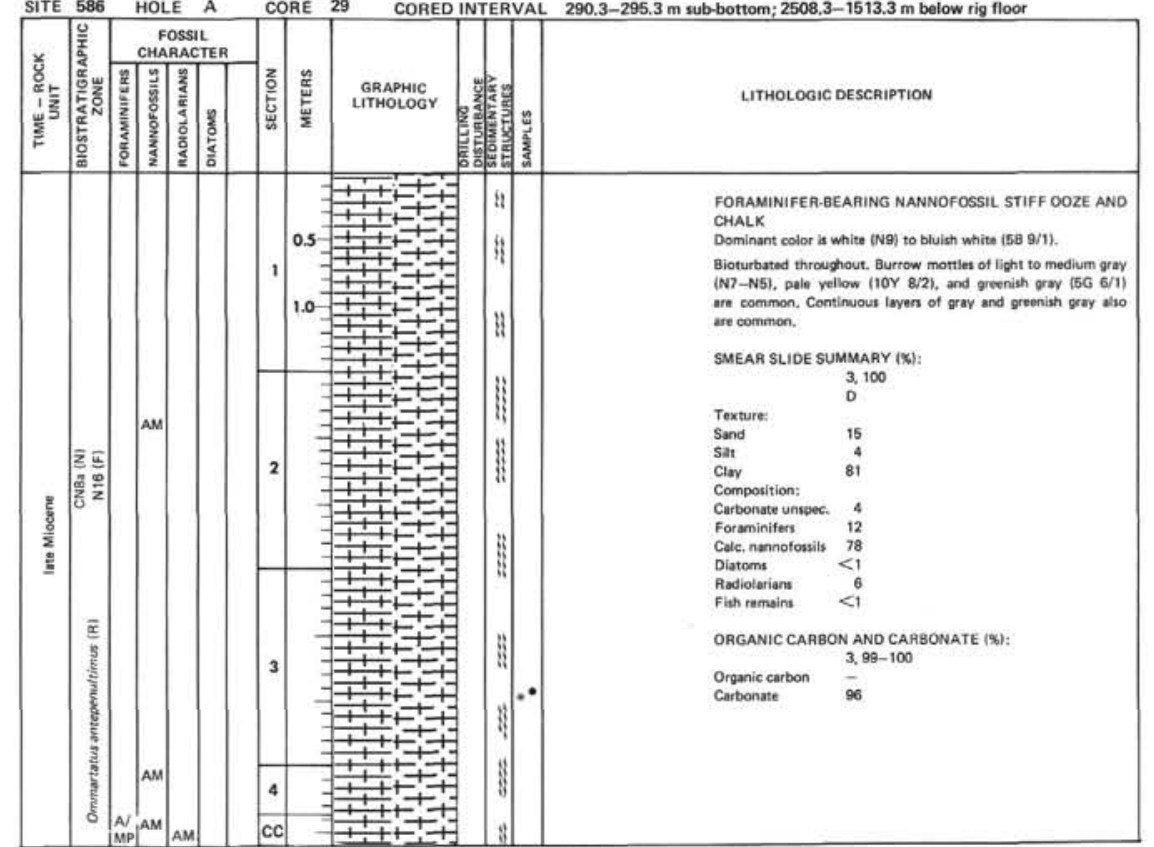



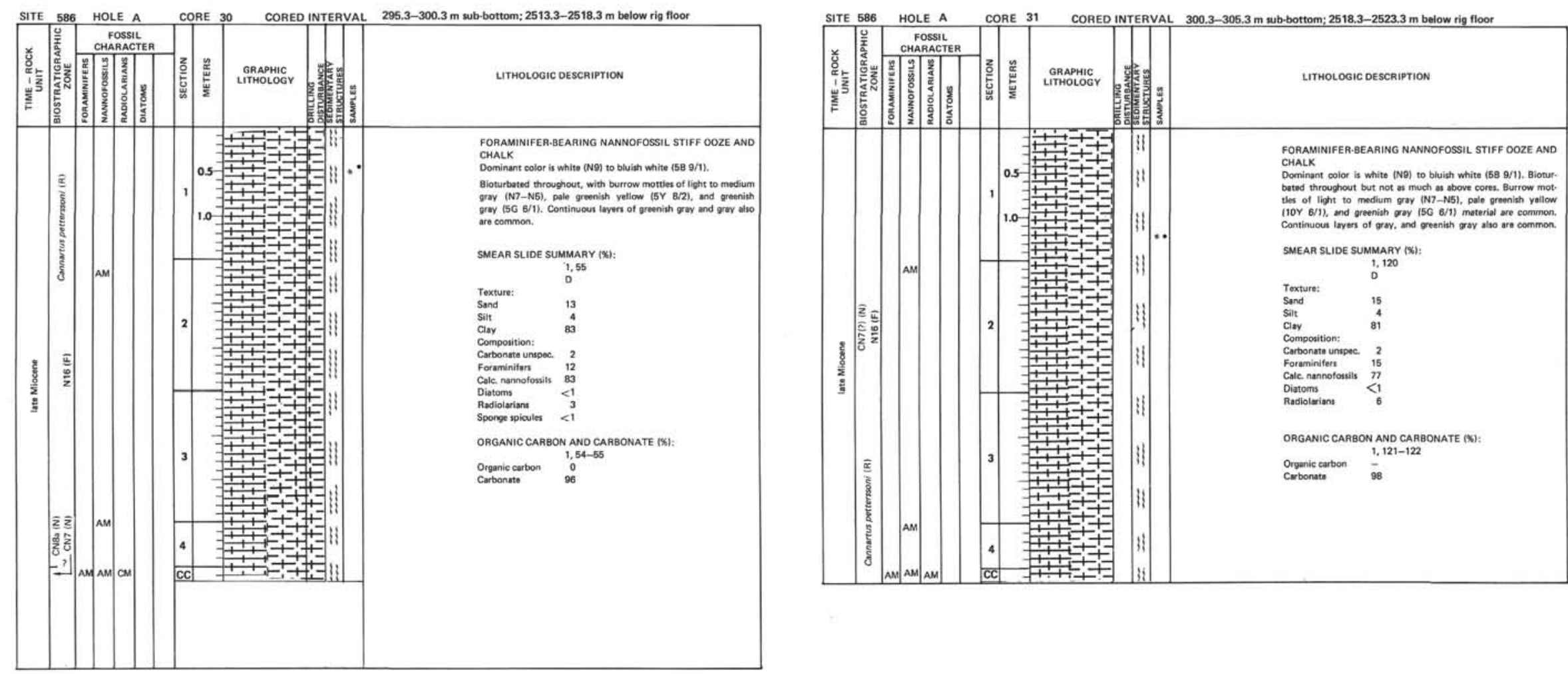
2

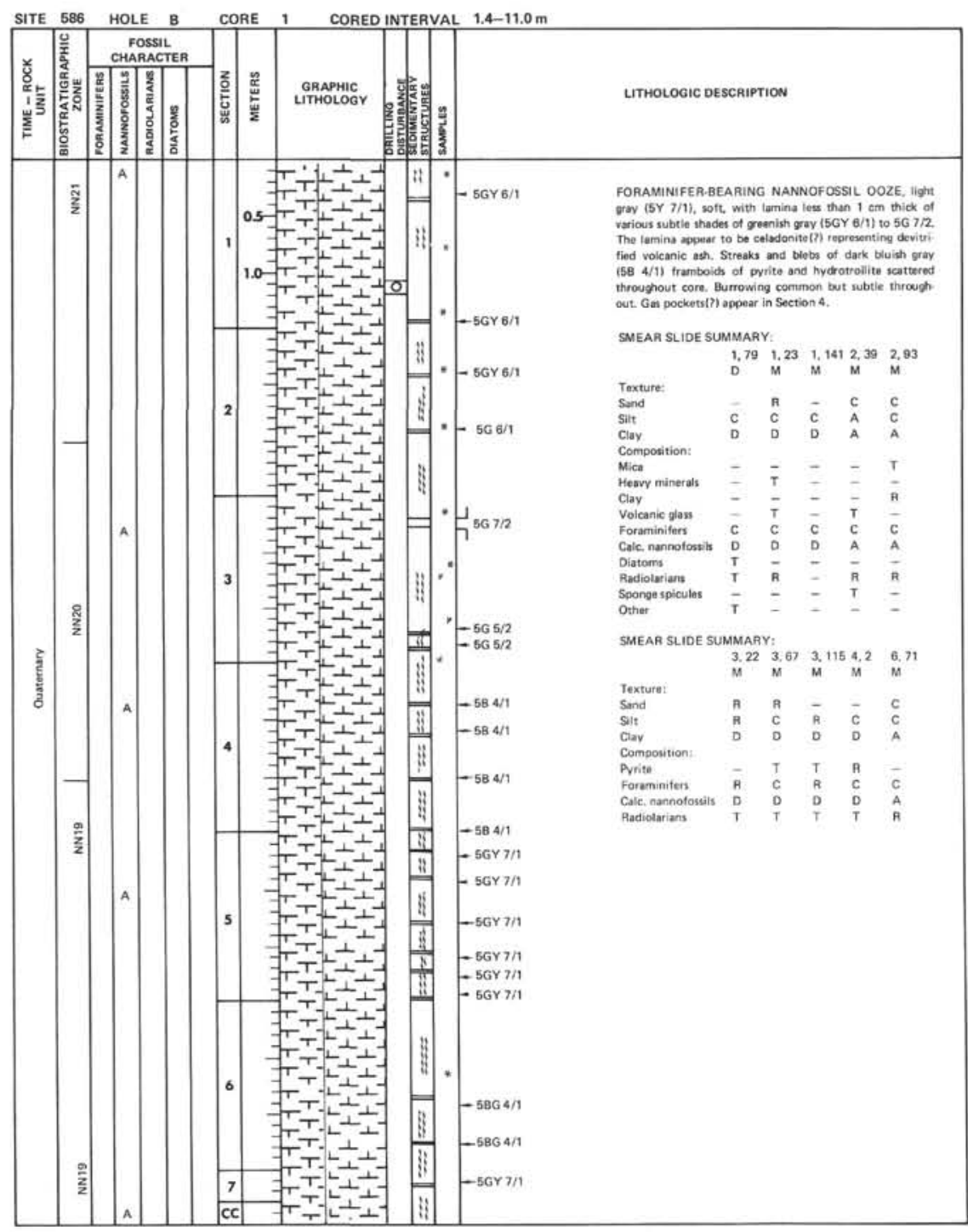

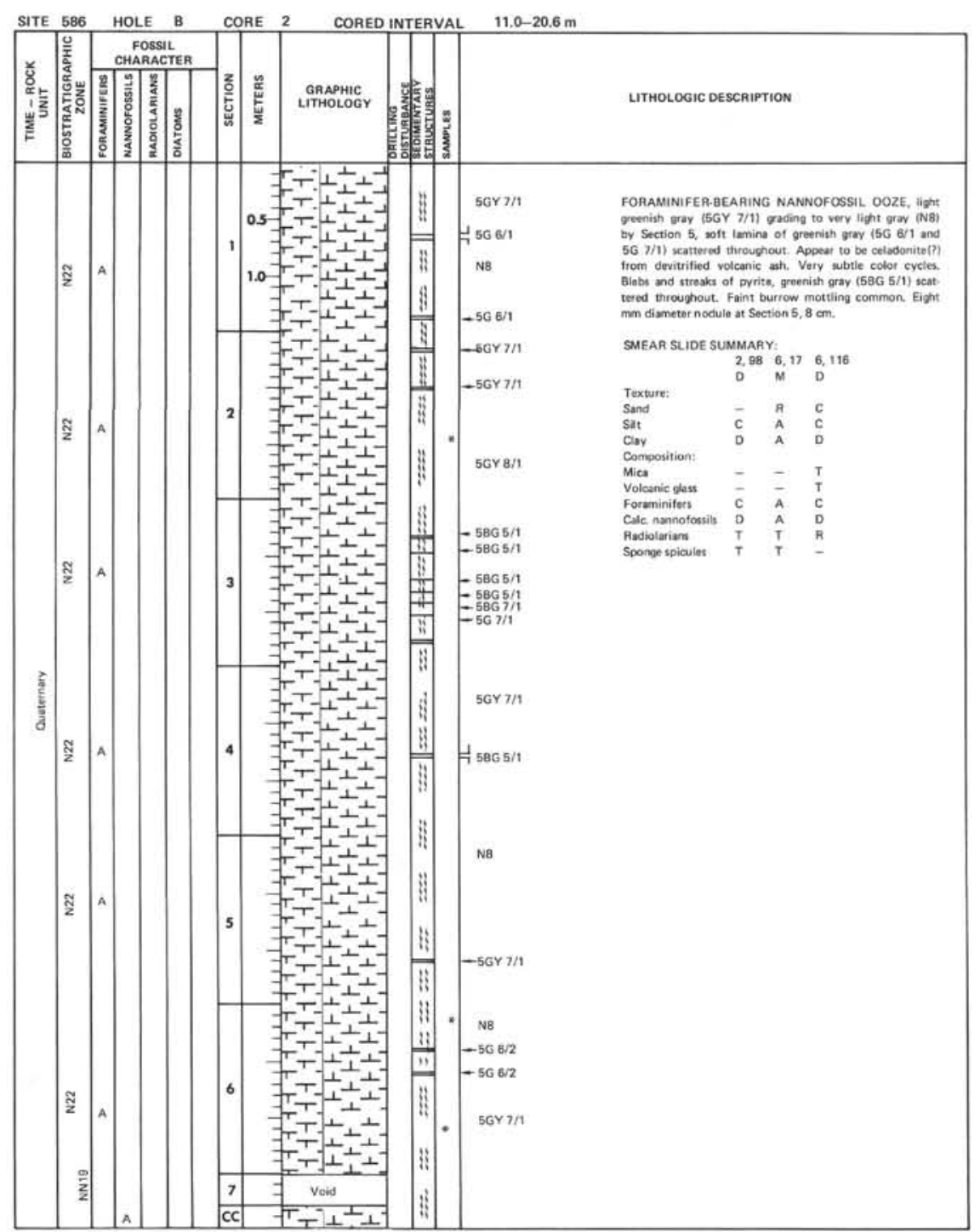



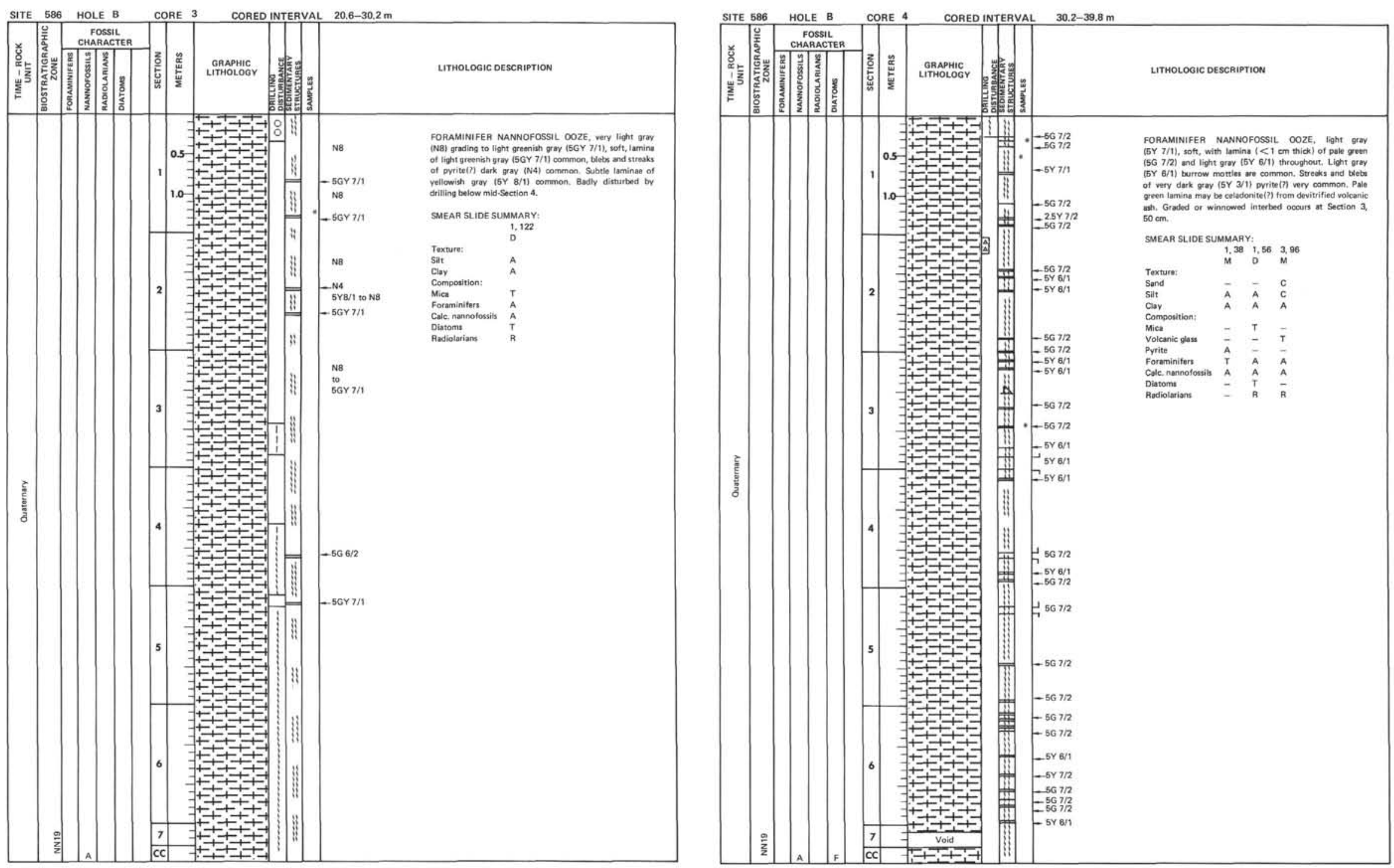
के

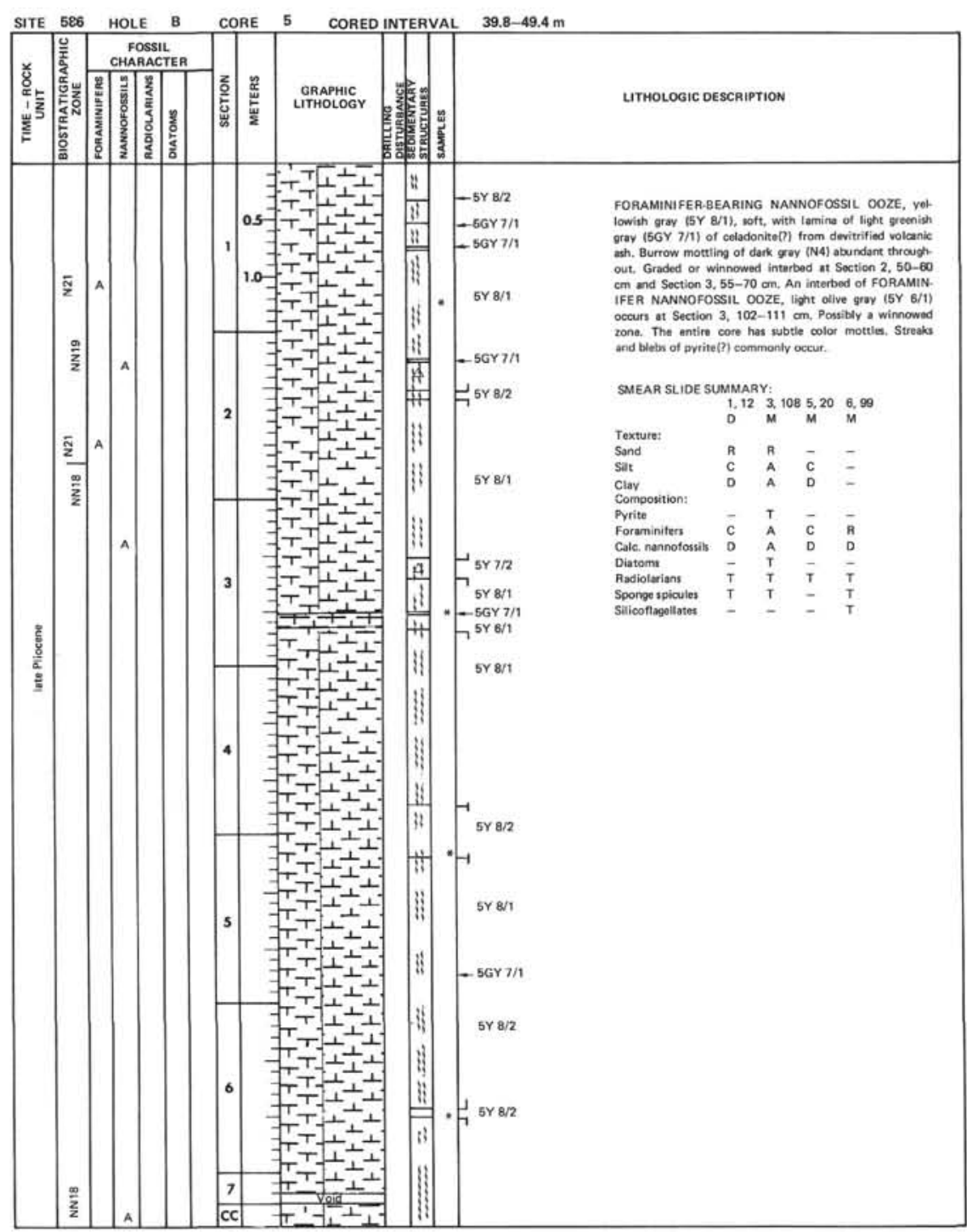

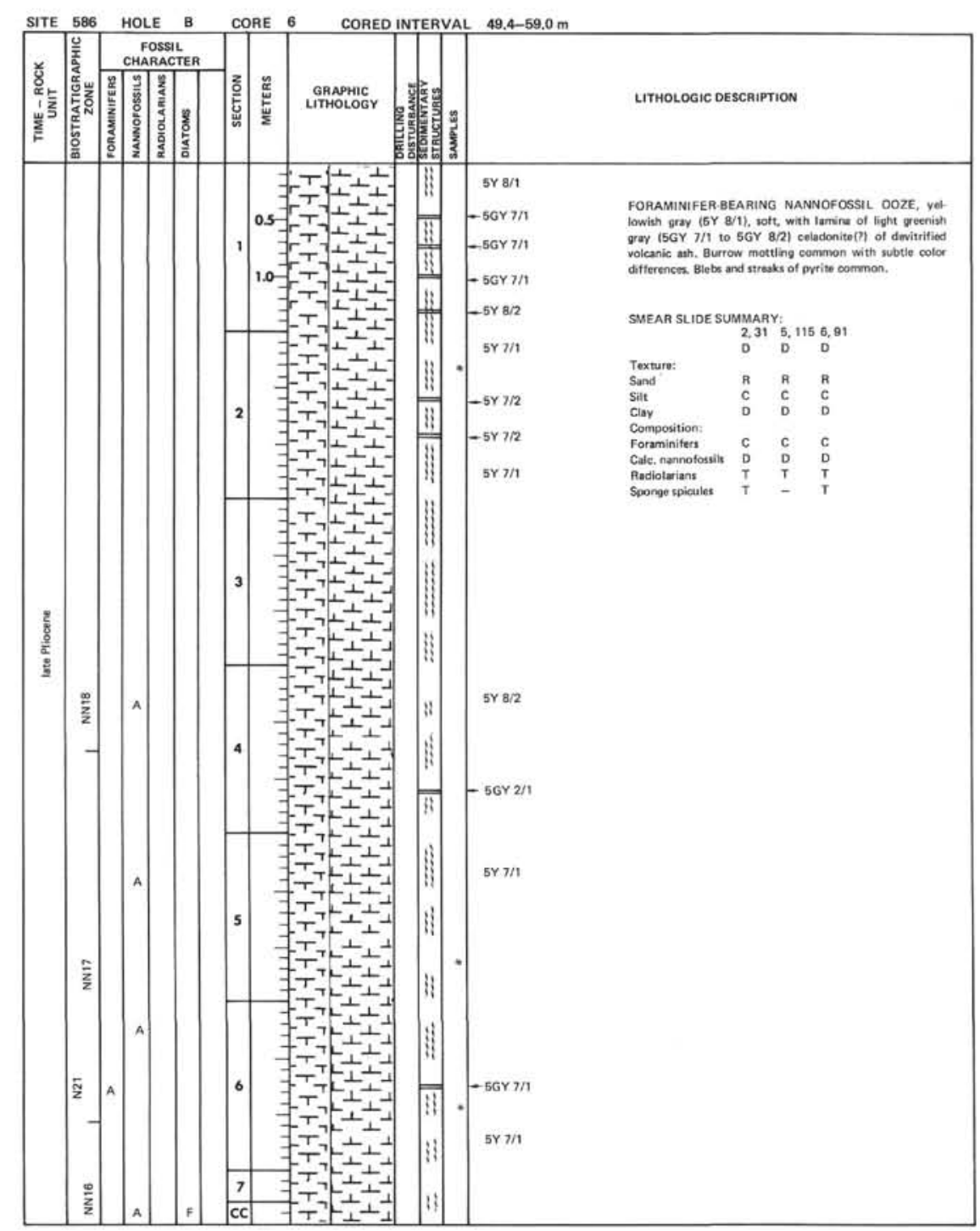



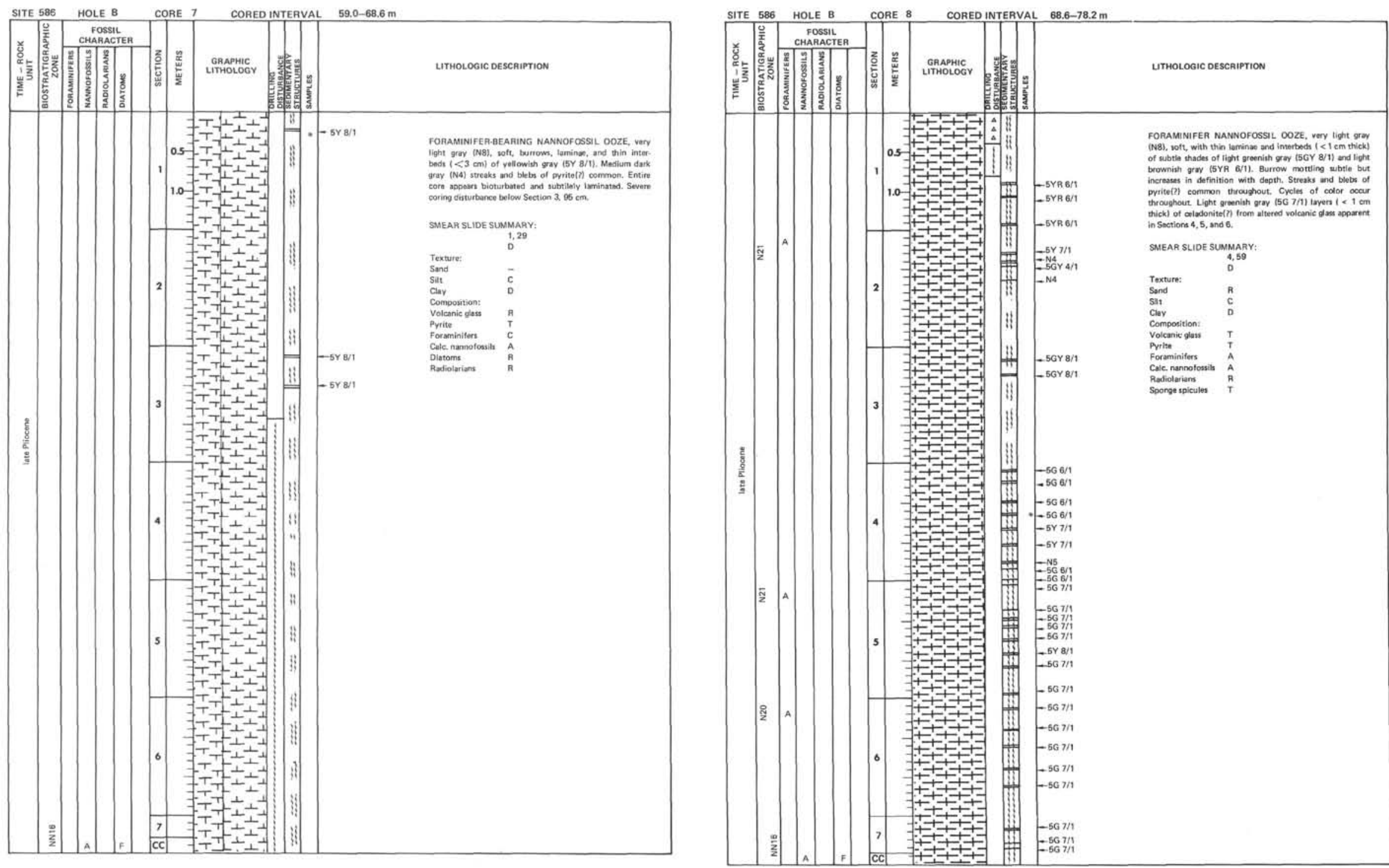

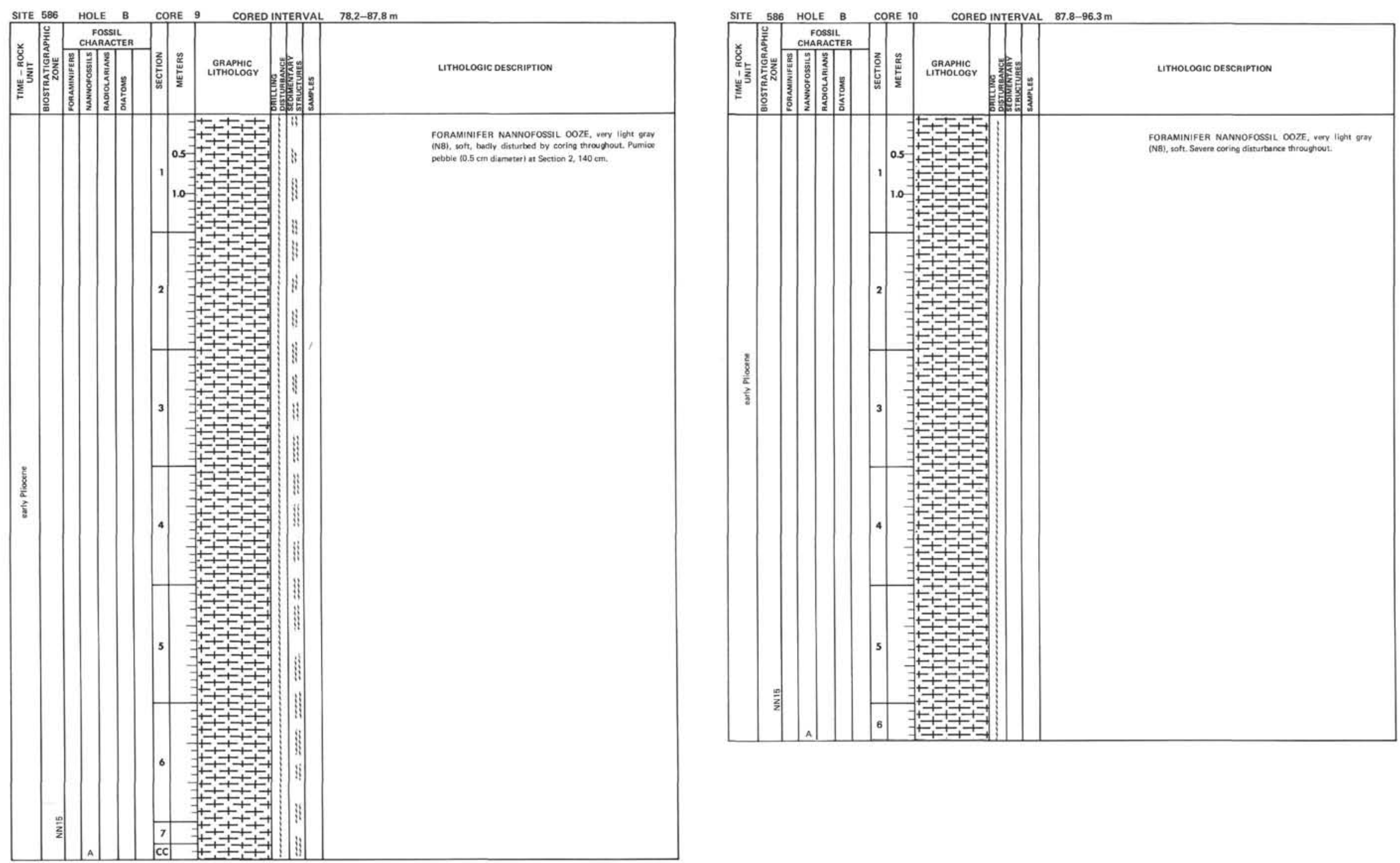

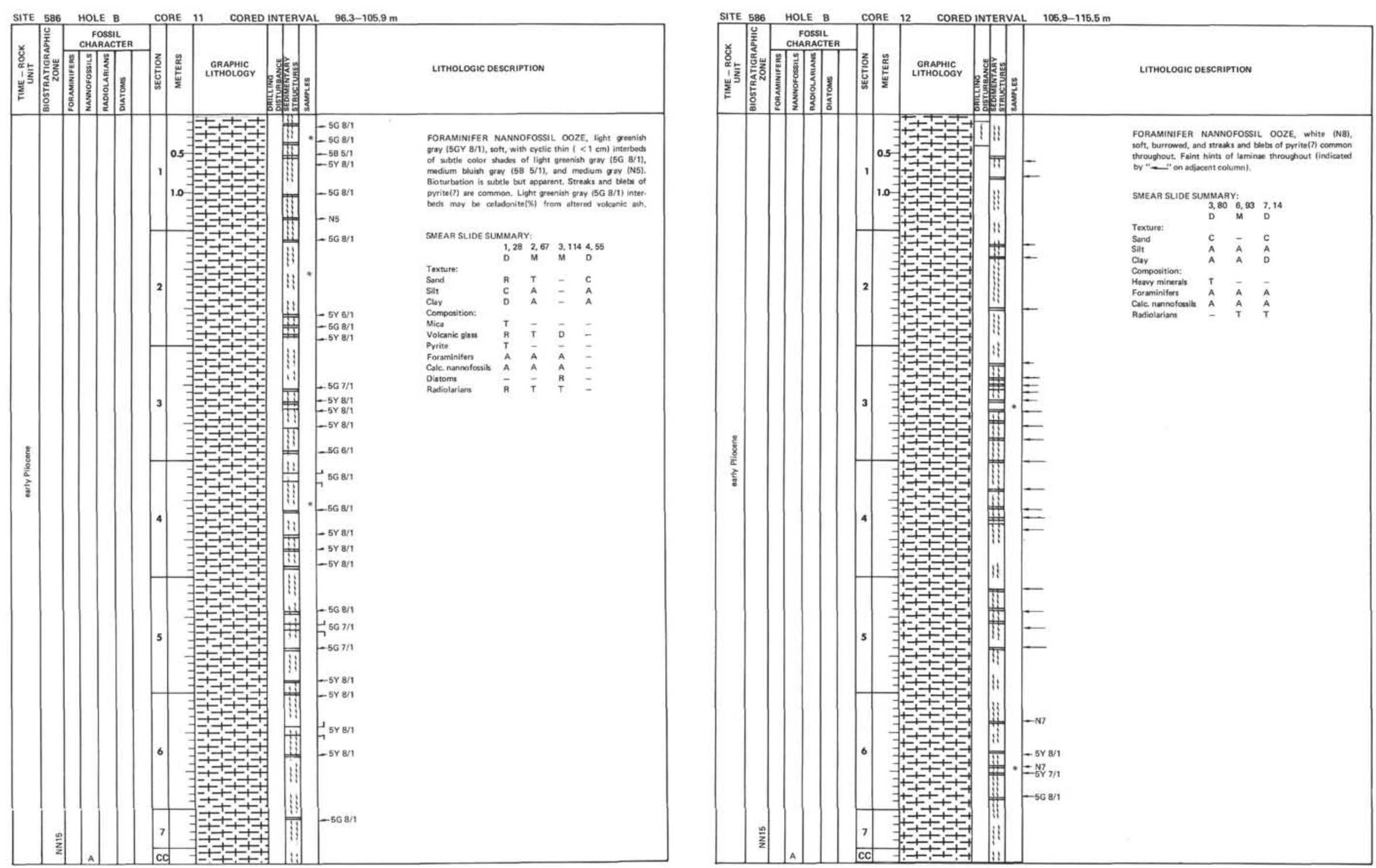

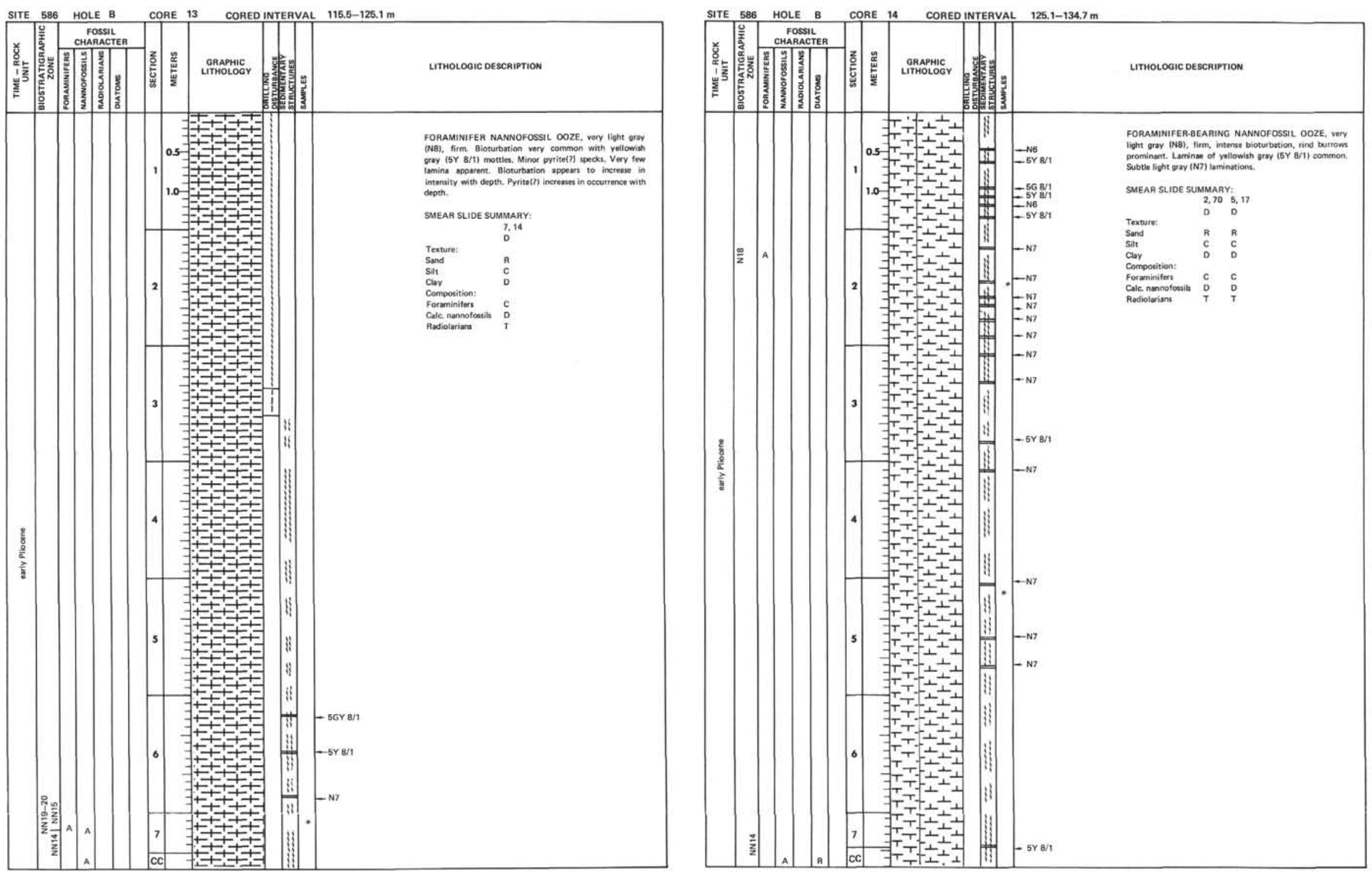

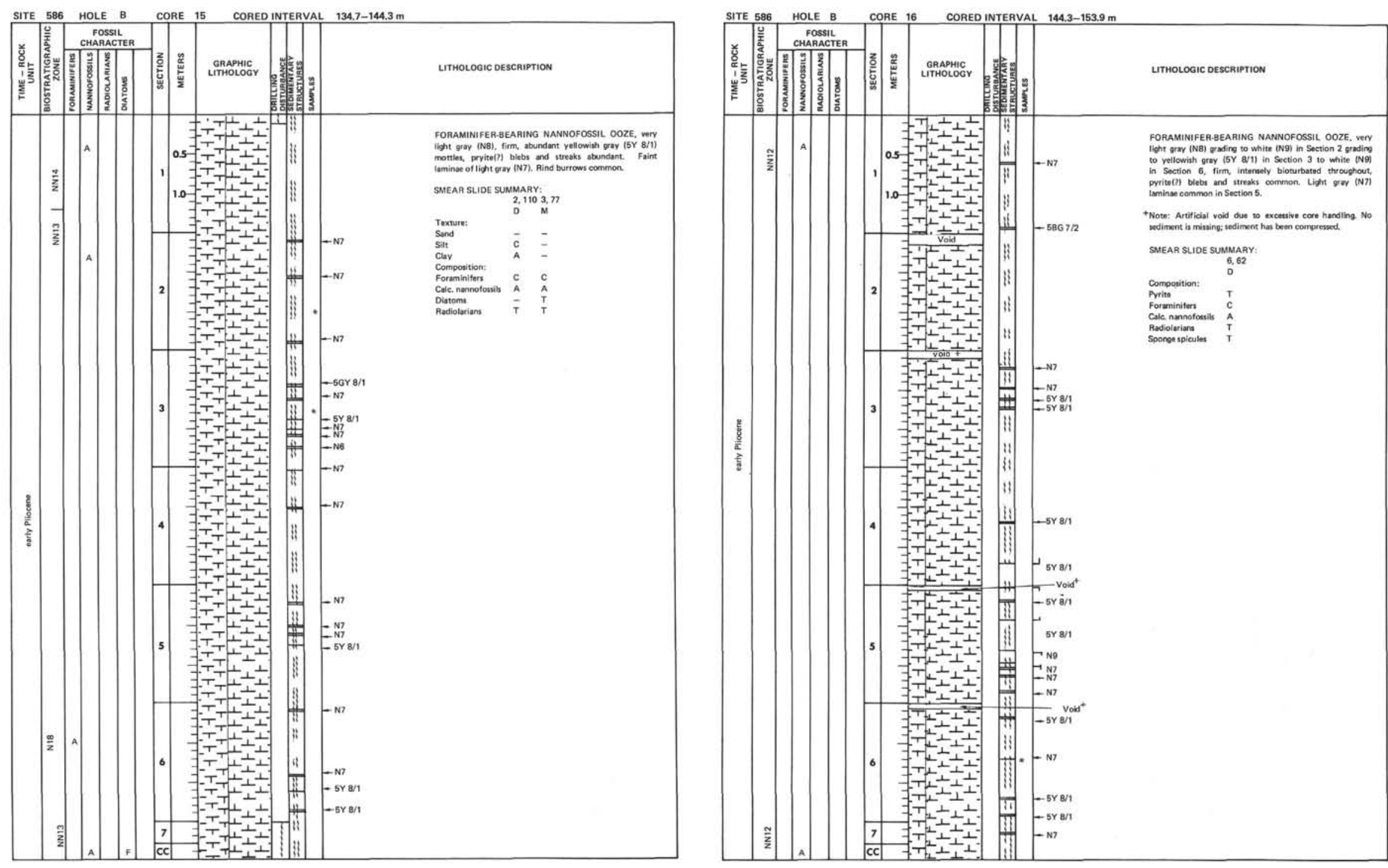


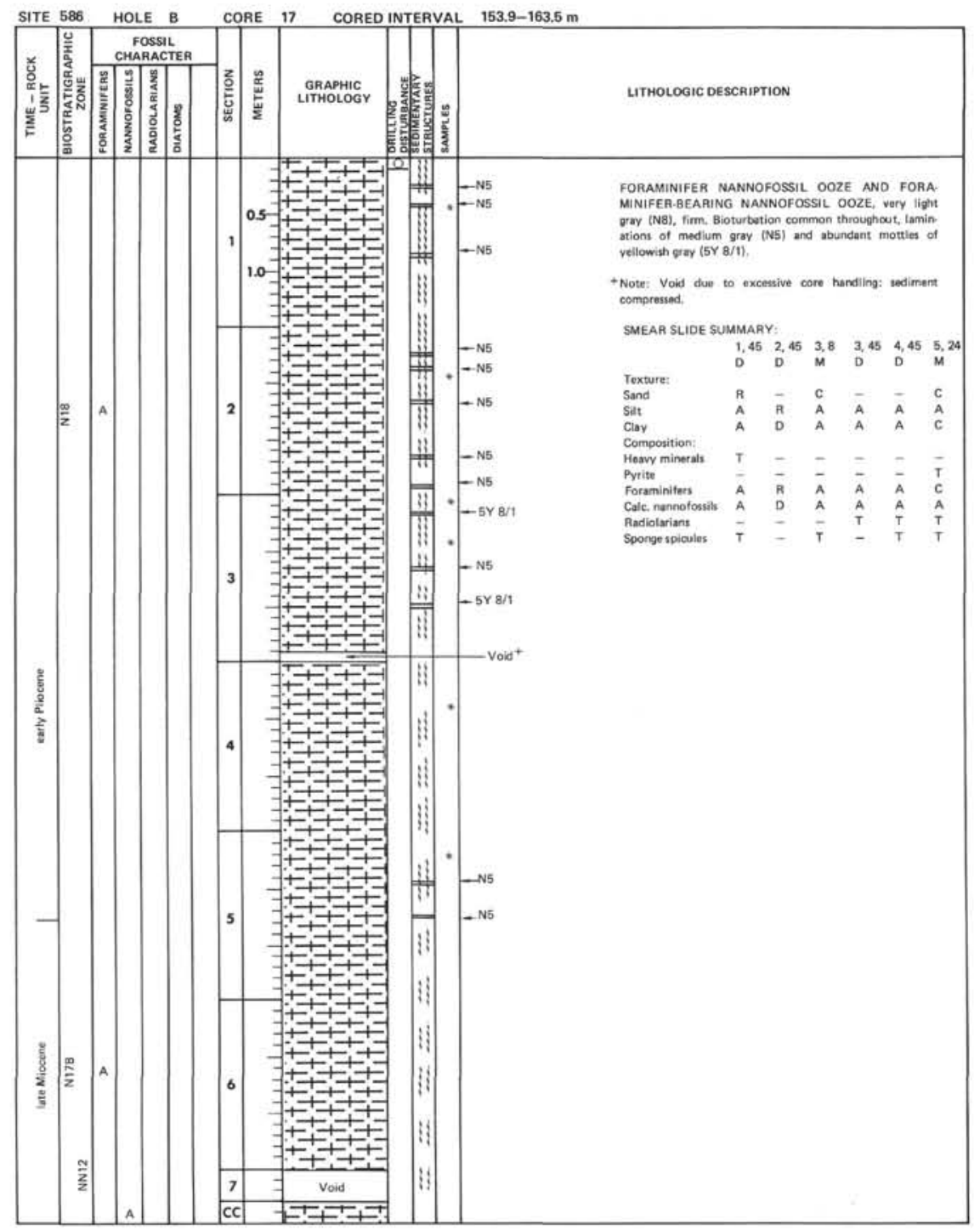

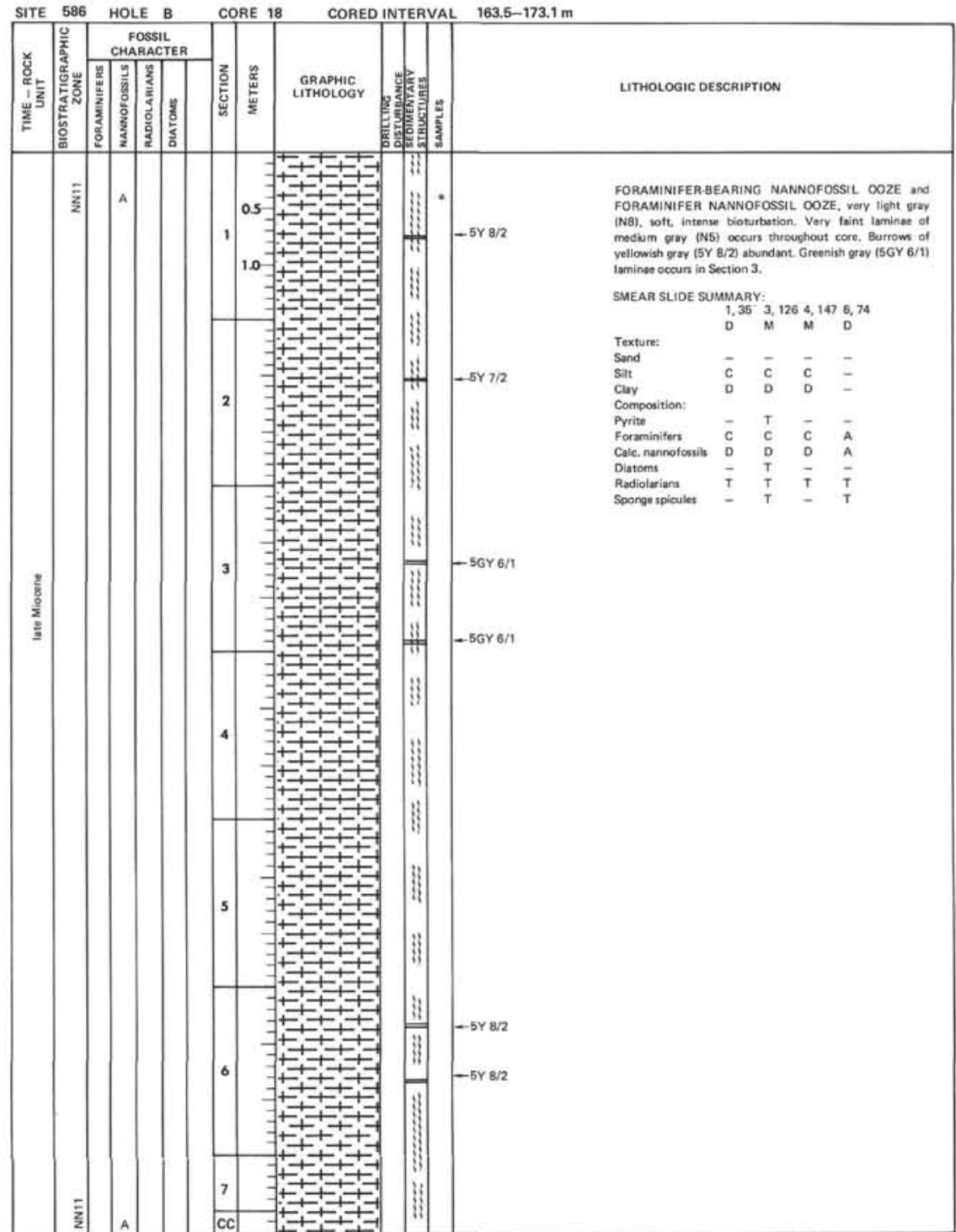



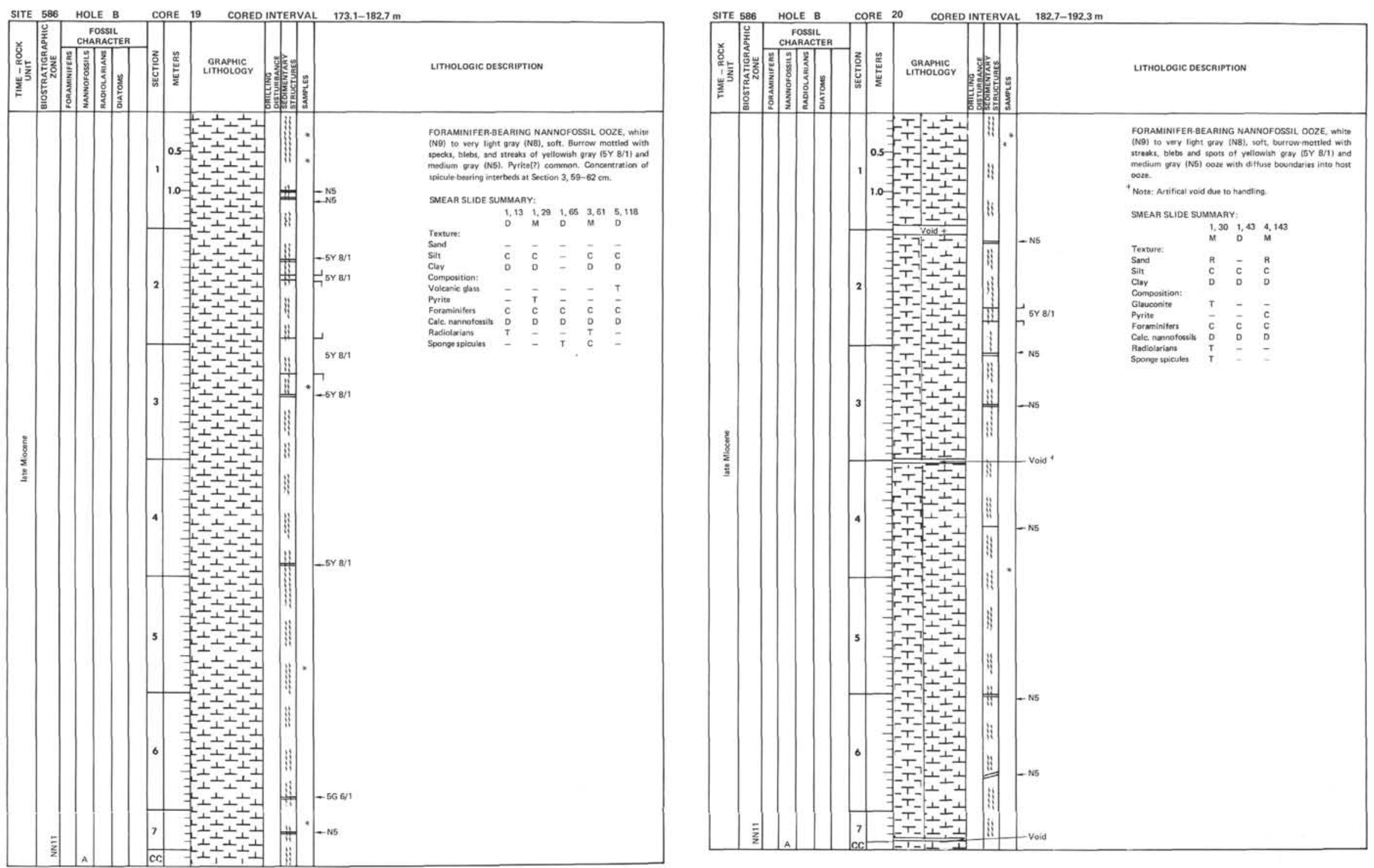
$\alpha$

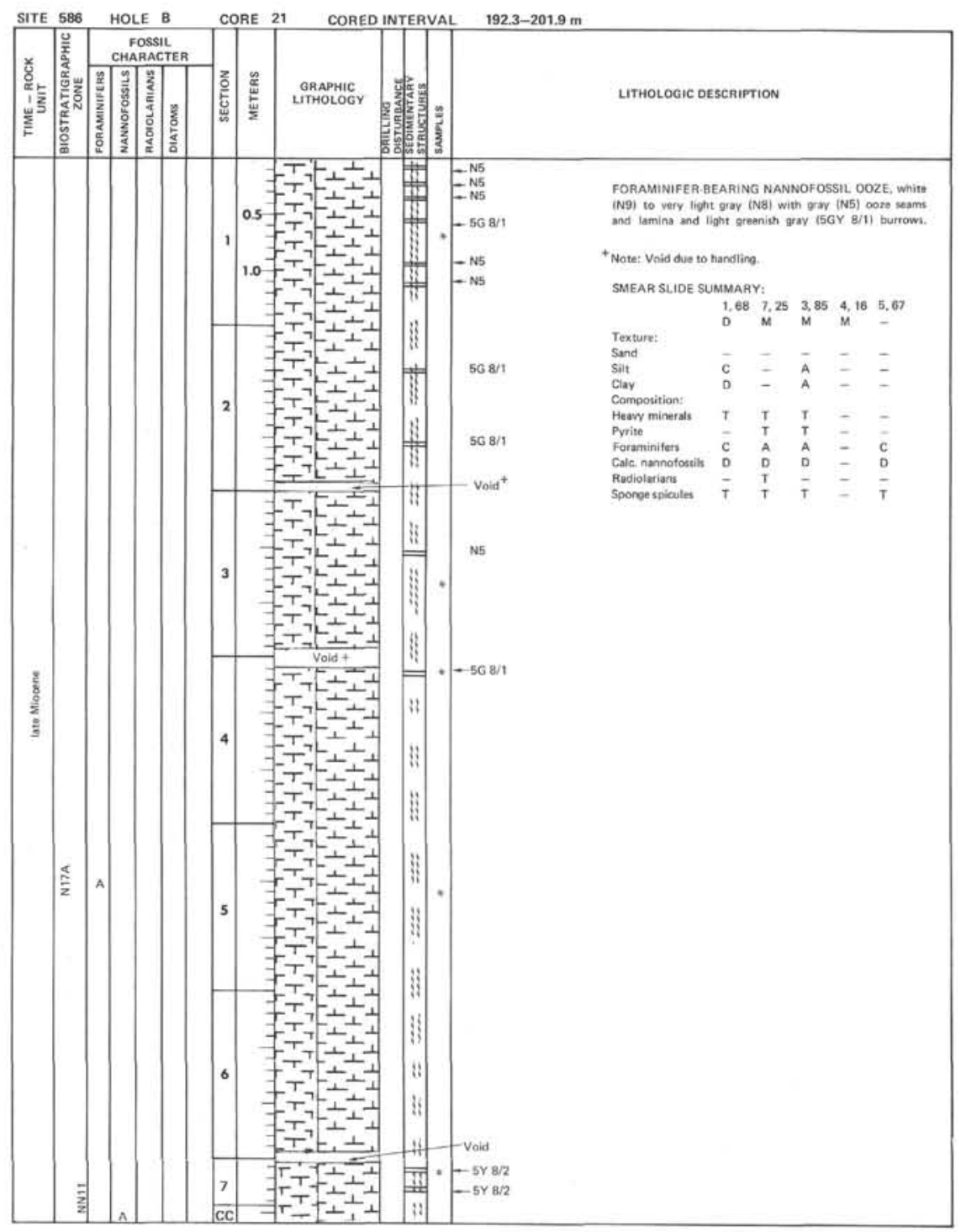

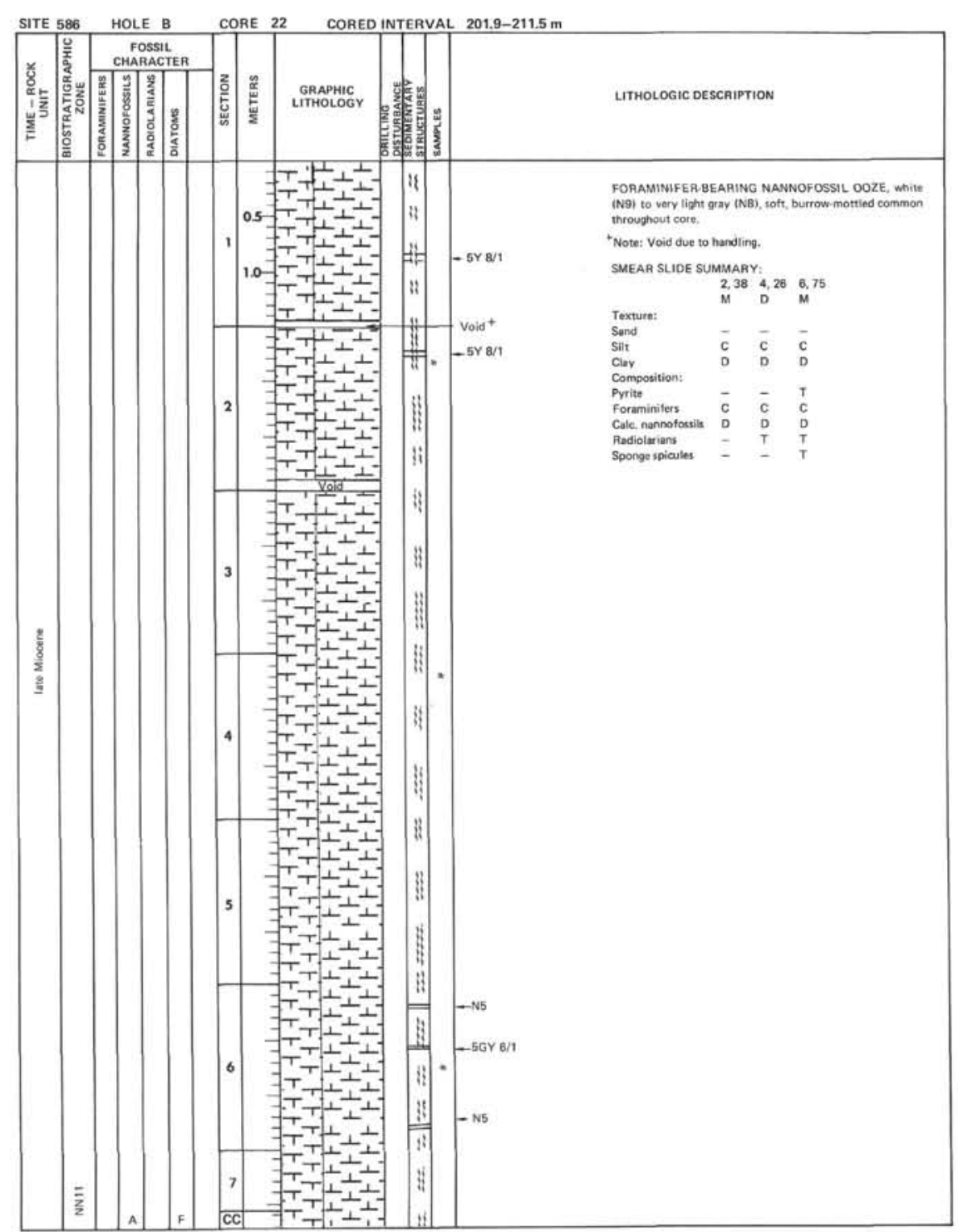



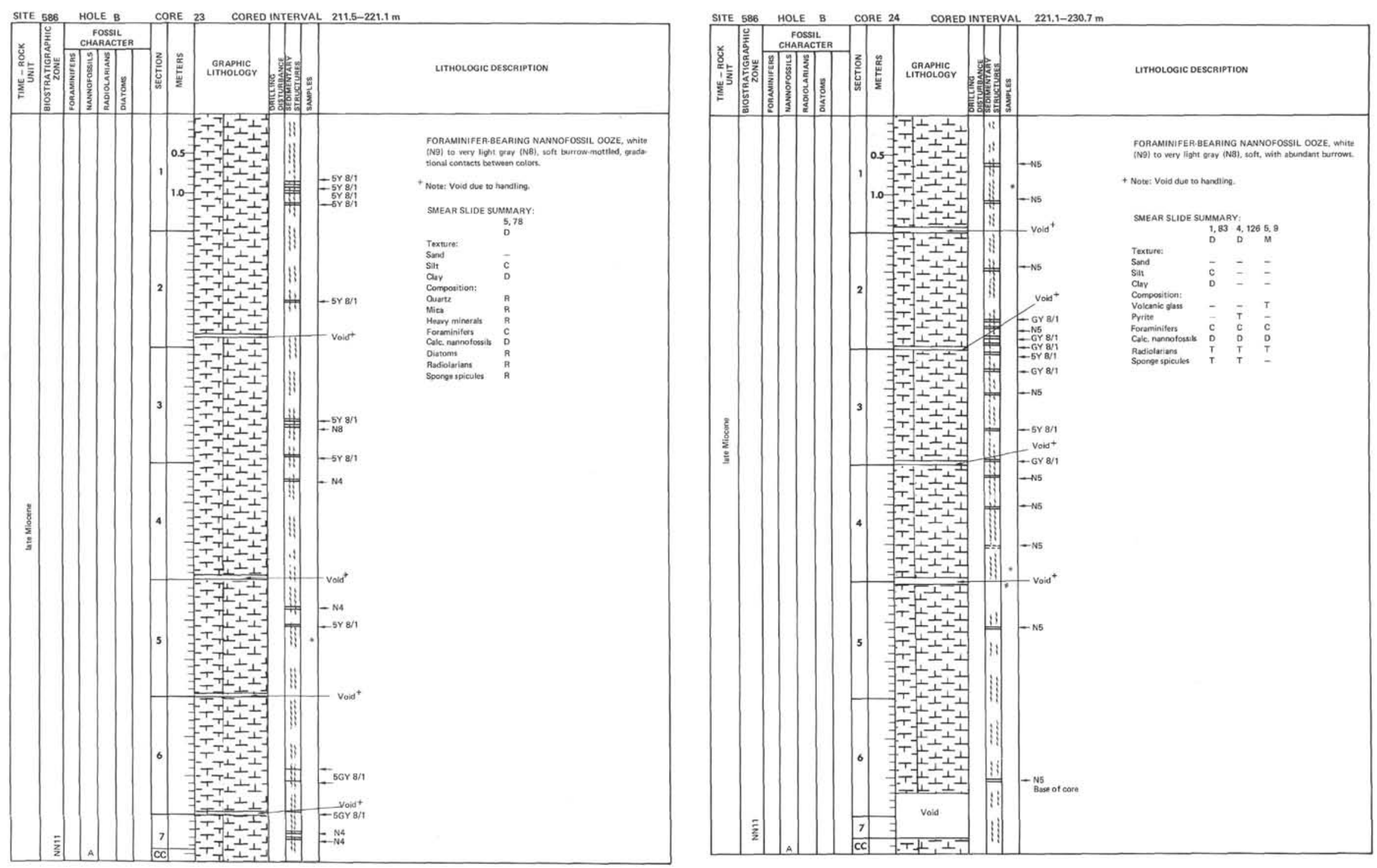

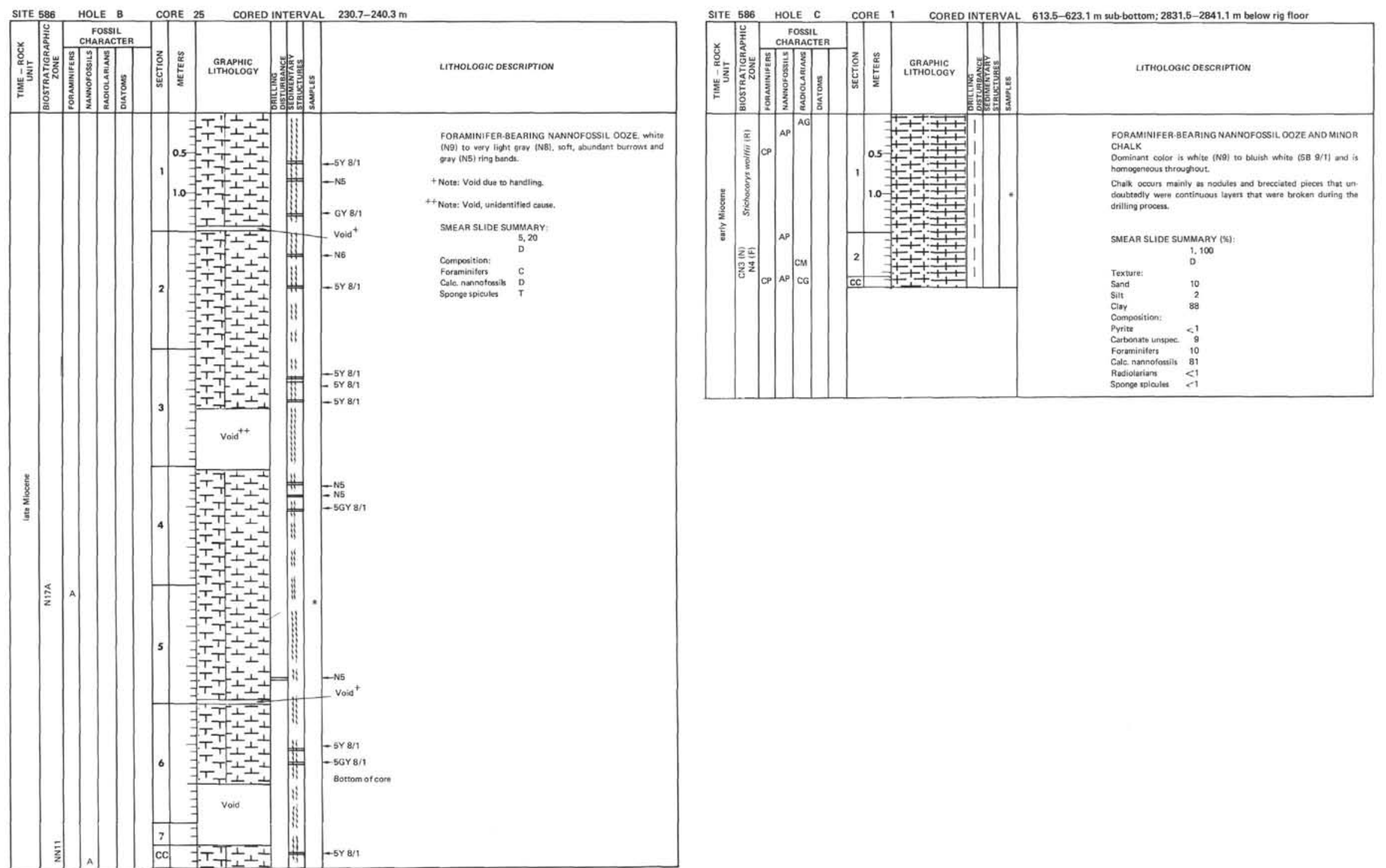


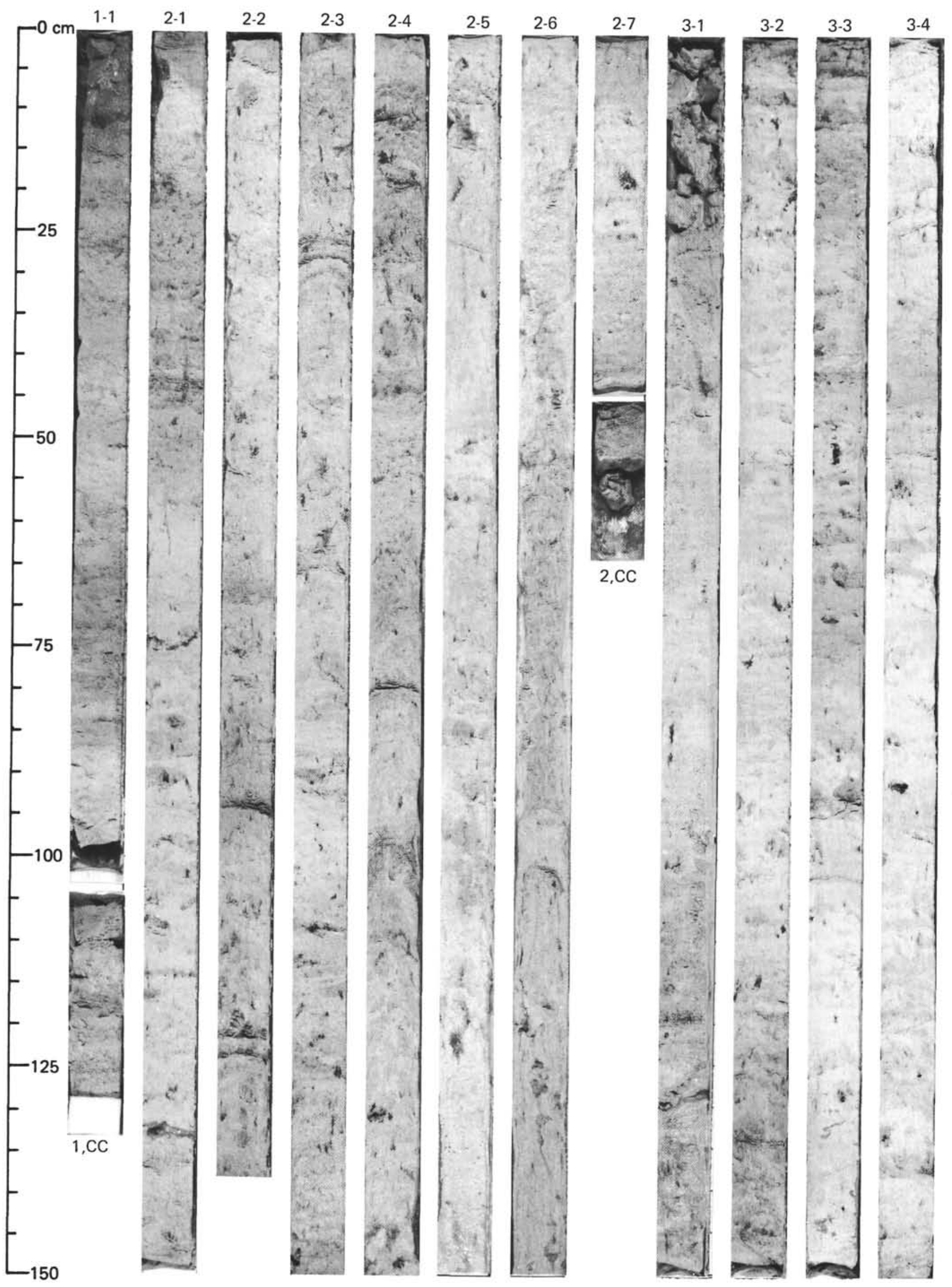




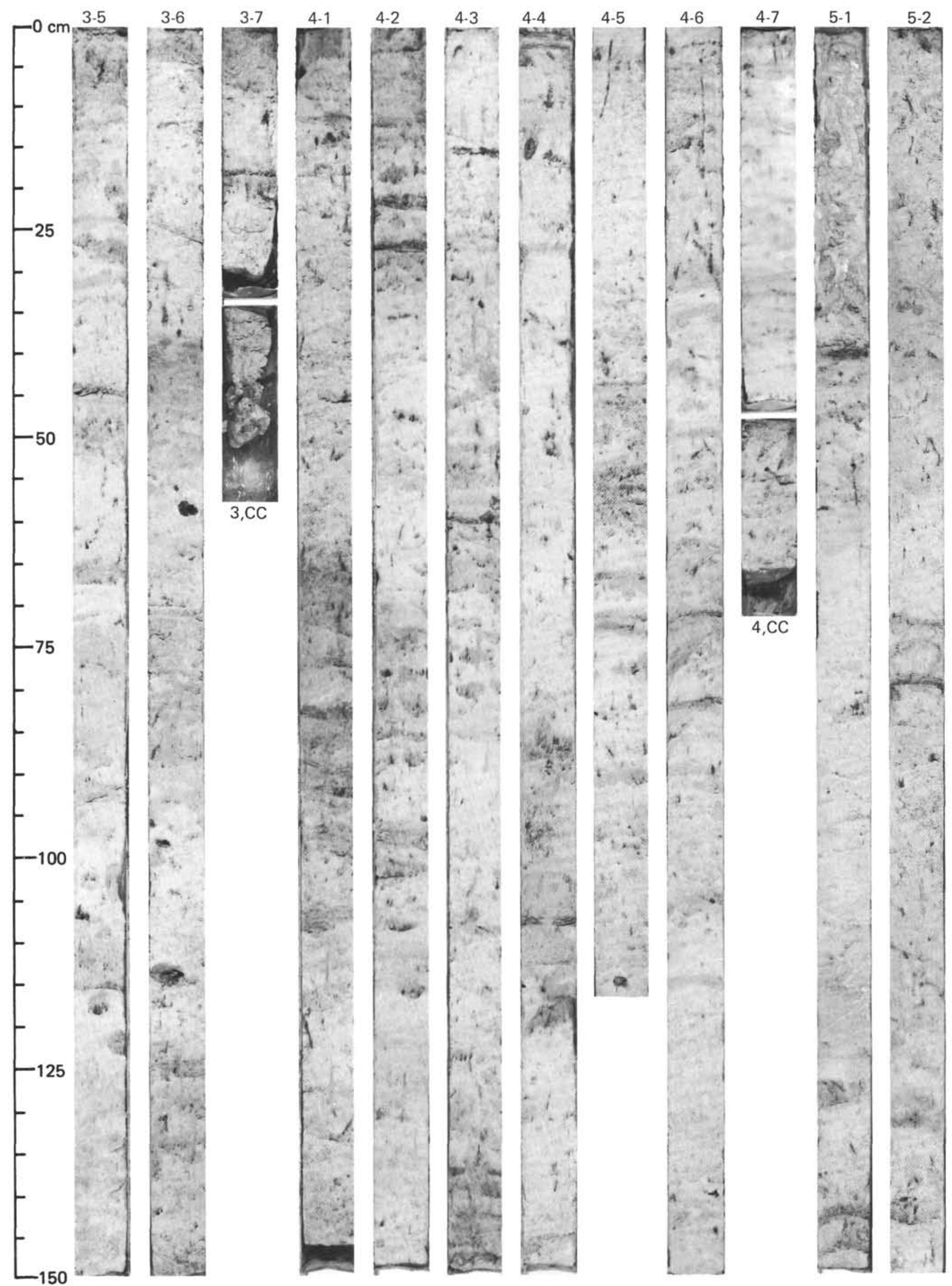




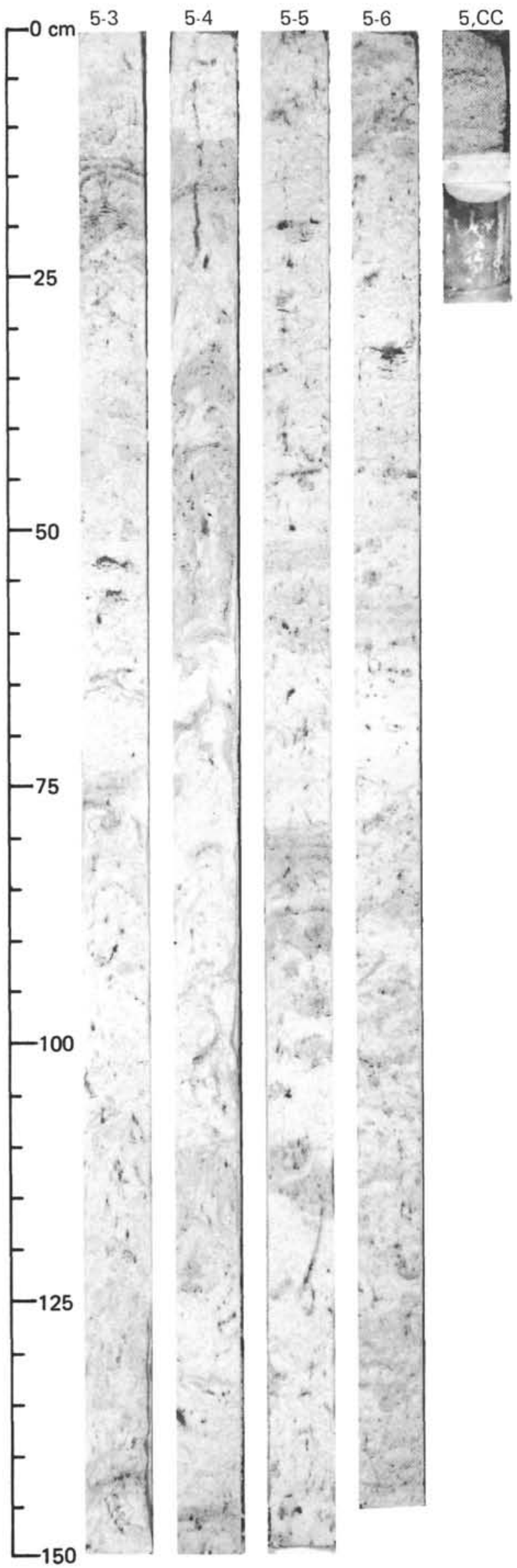




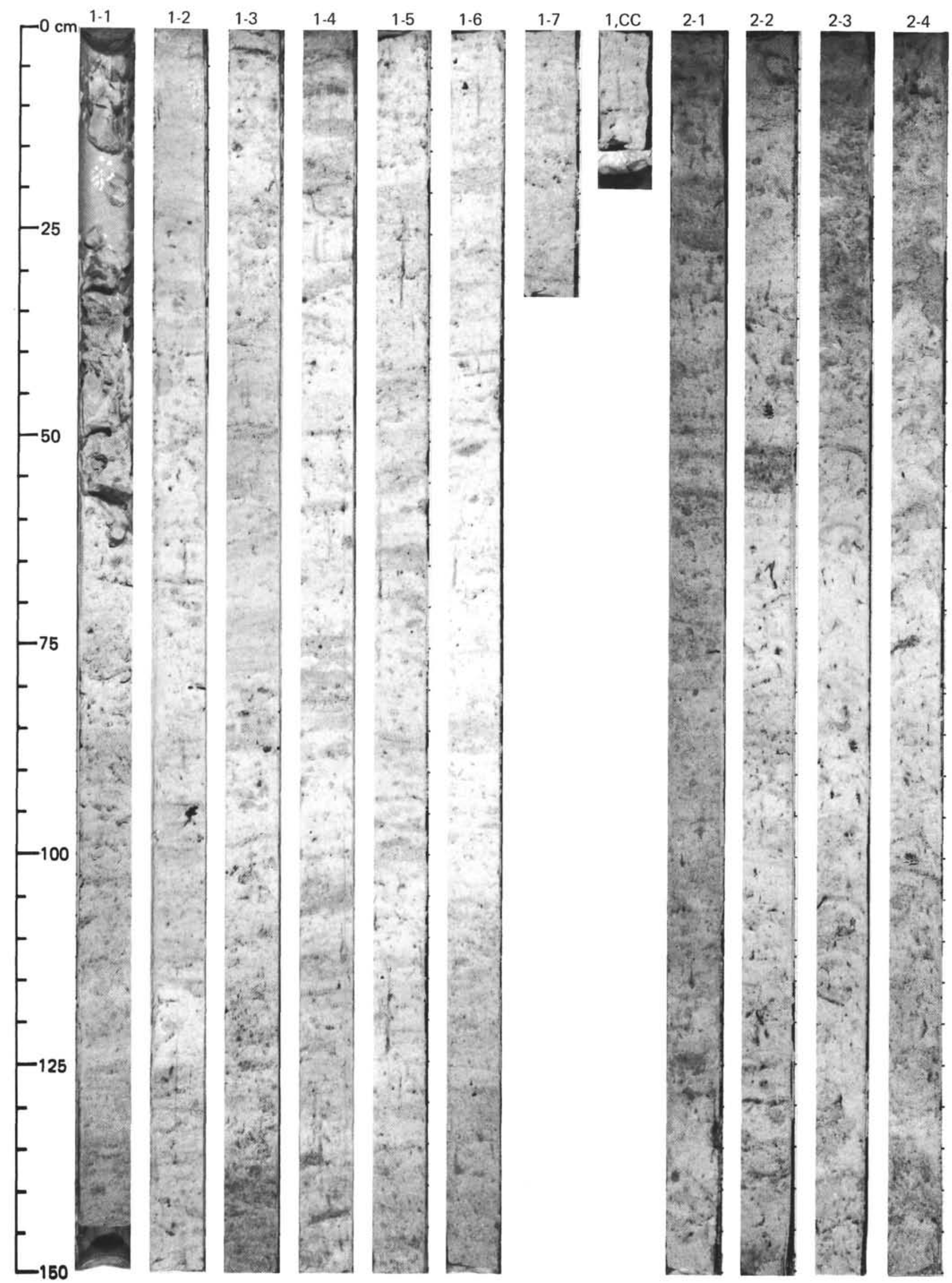


SITE 586 (HOLE 586A)

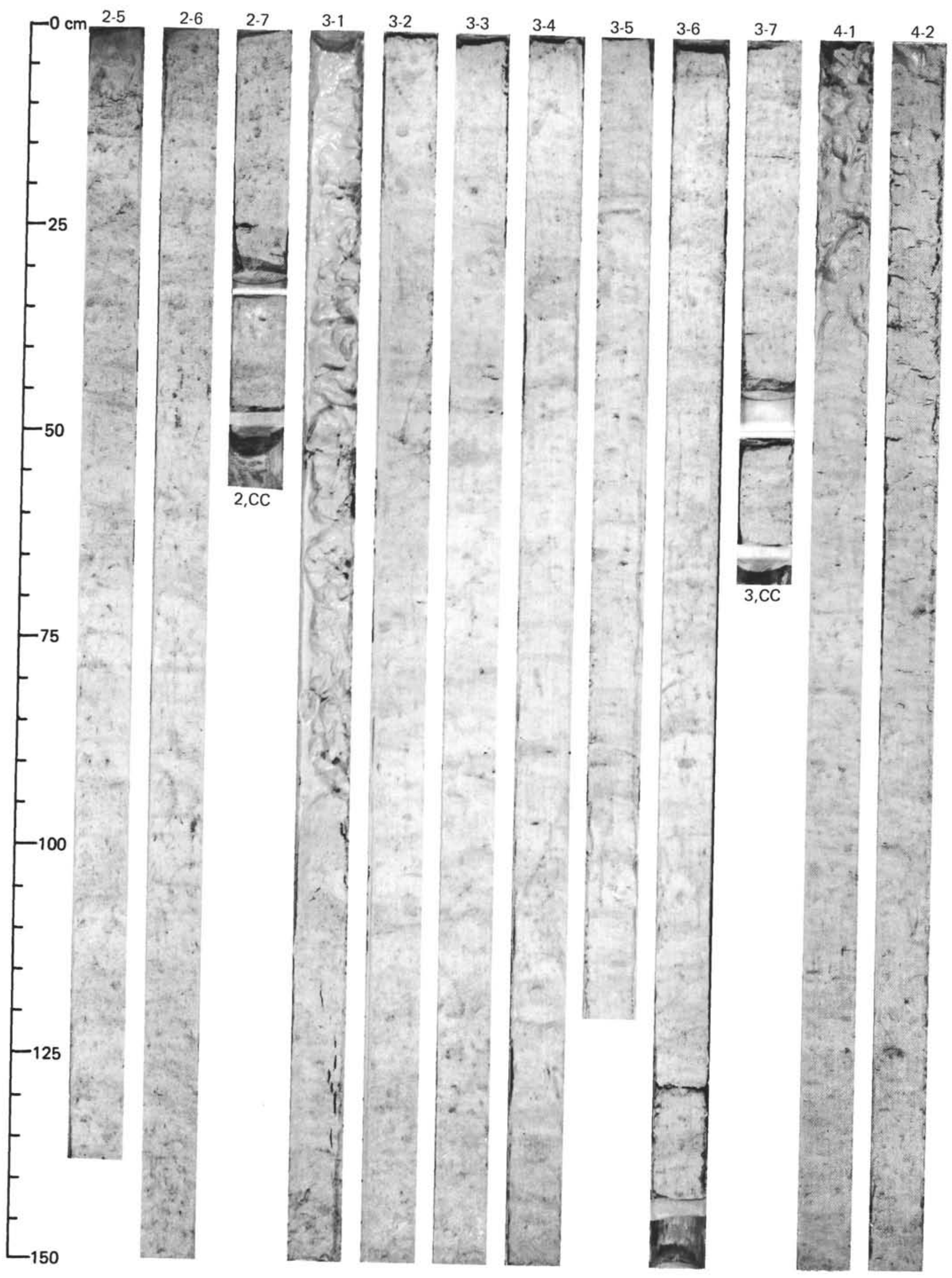




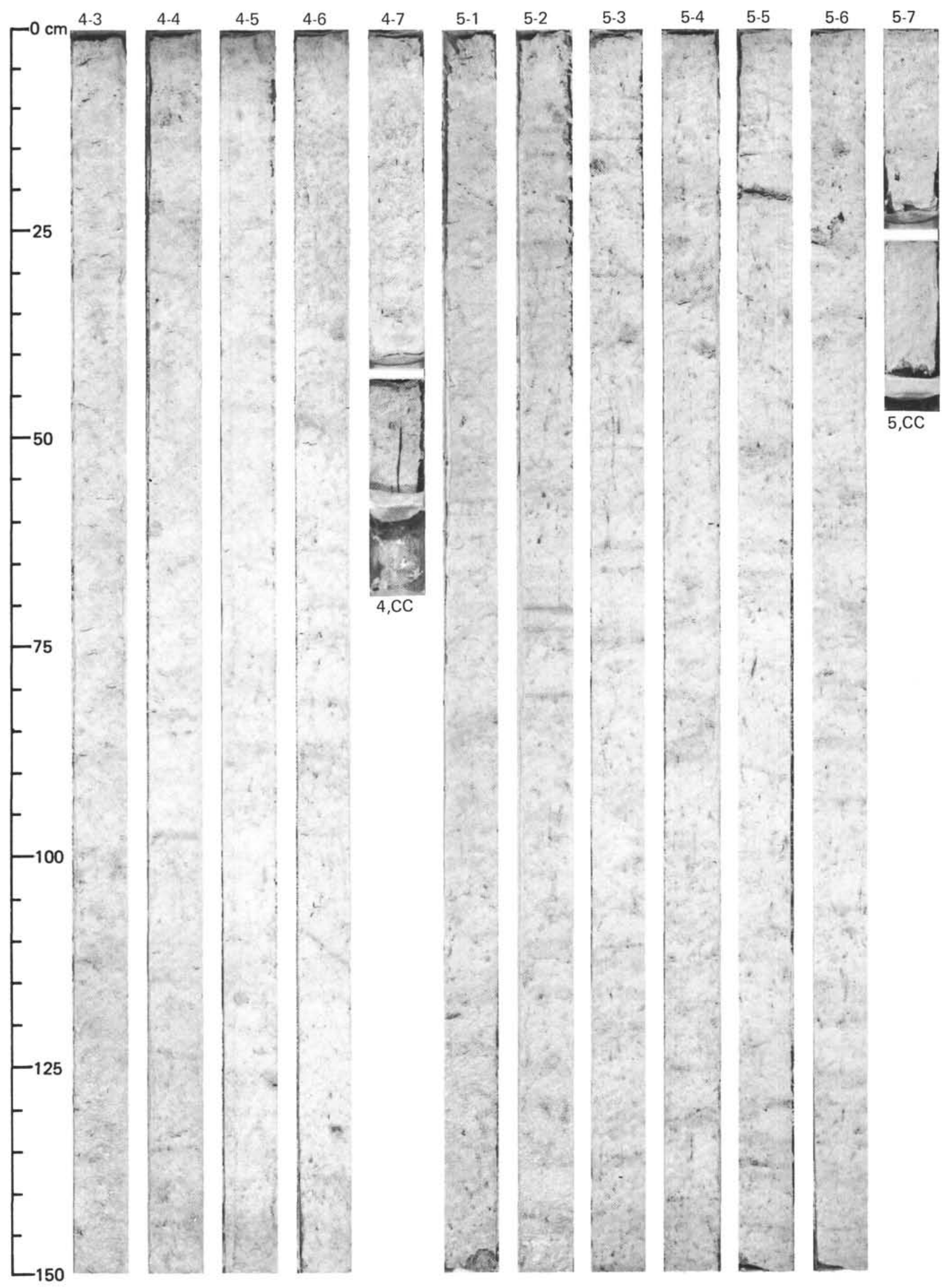




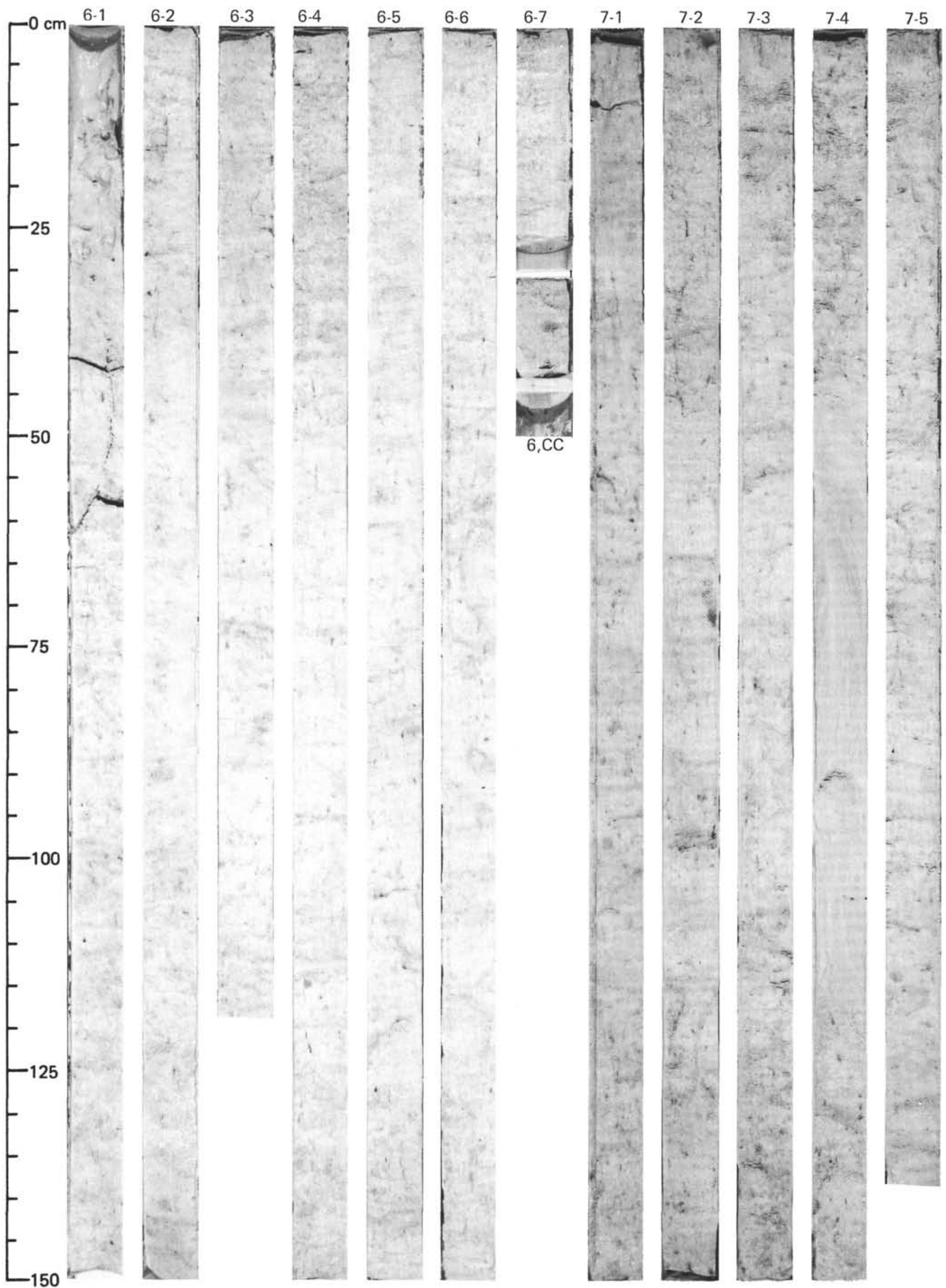




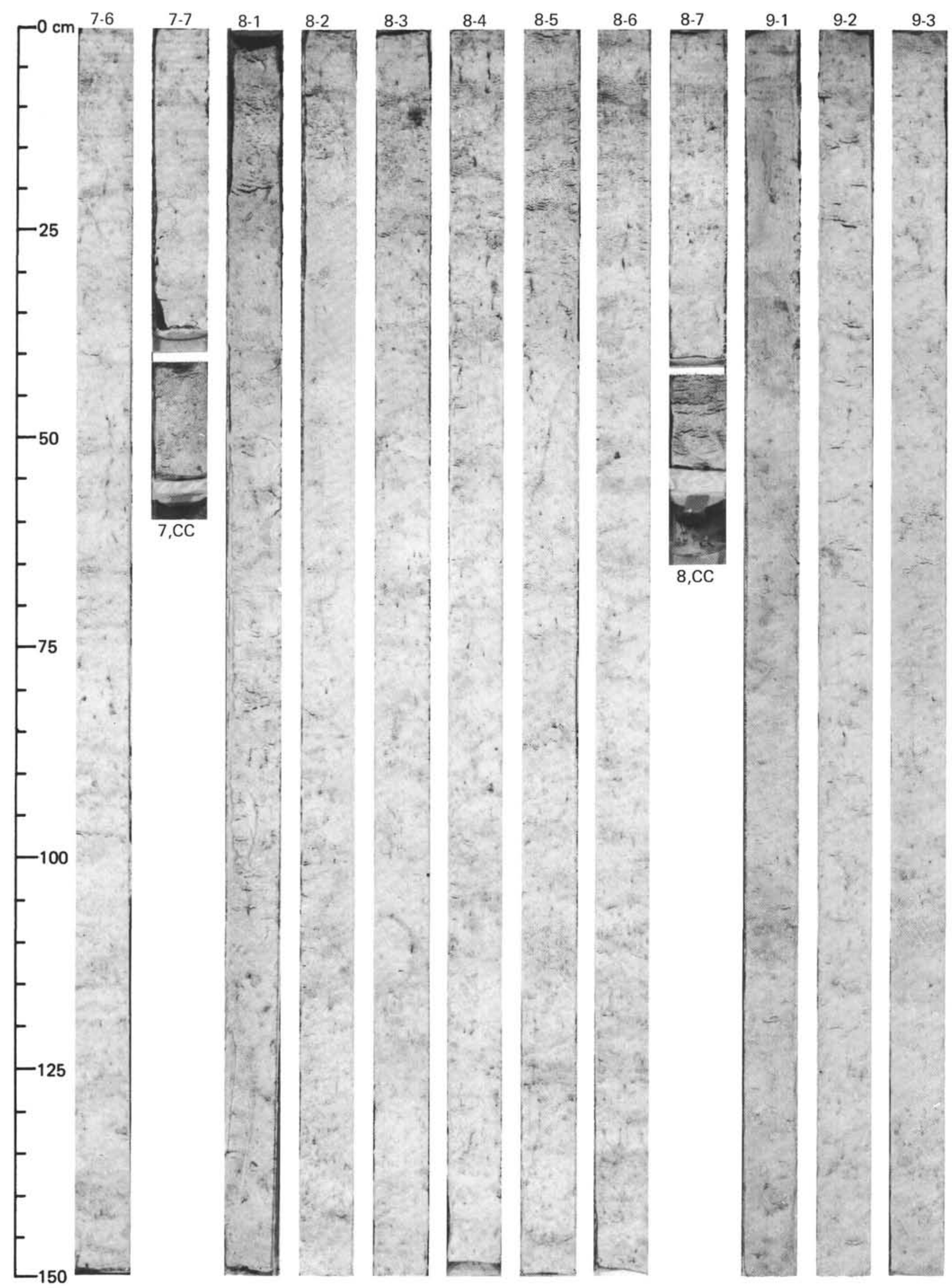




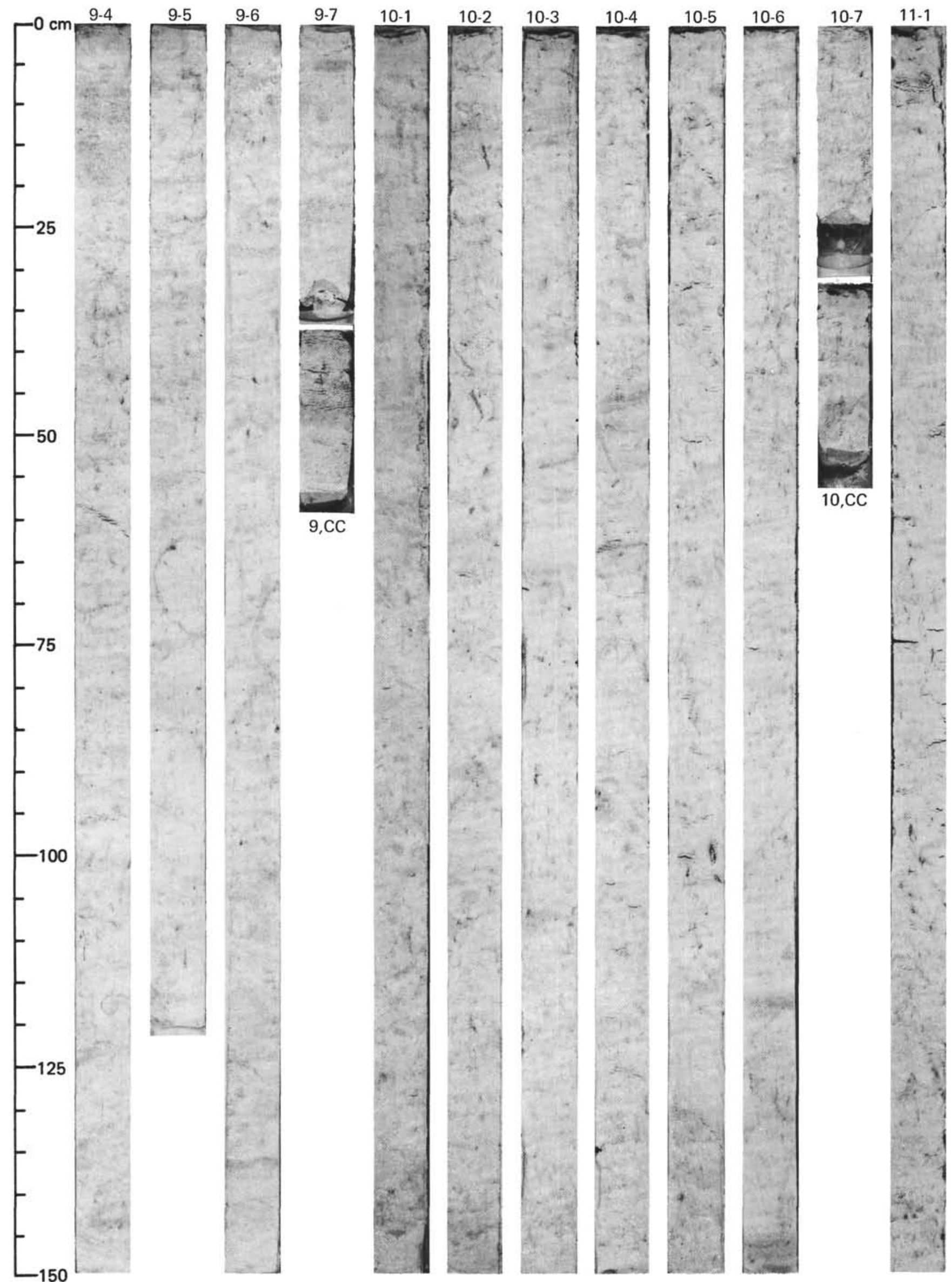


SITE 586 (HOLE 586A)

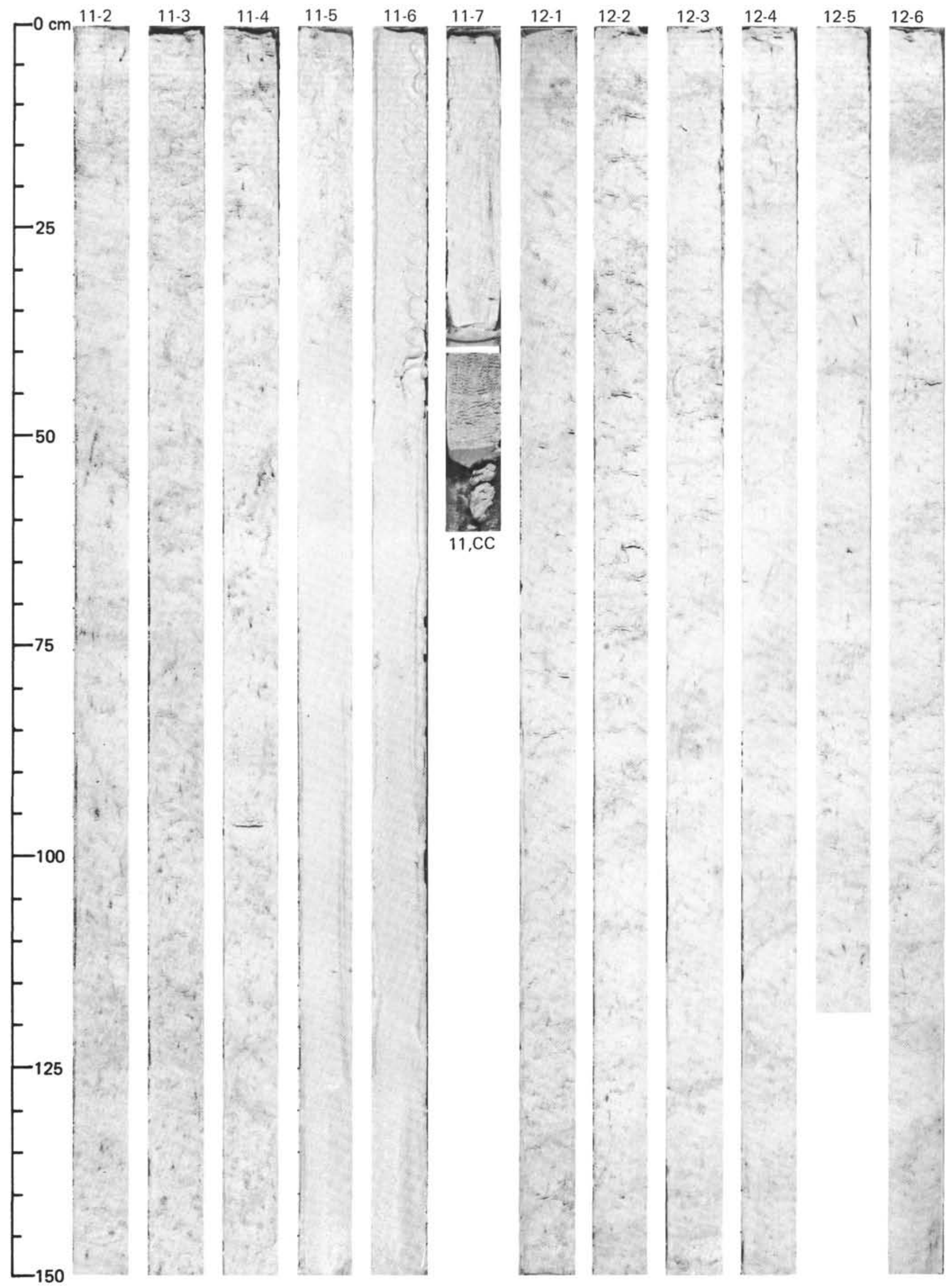


SITE 586 (HOLE 586A)

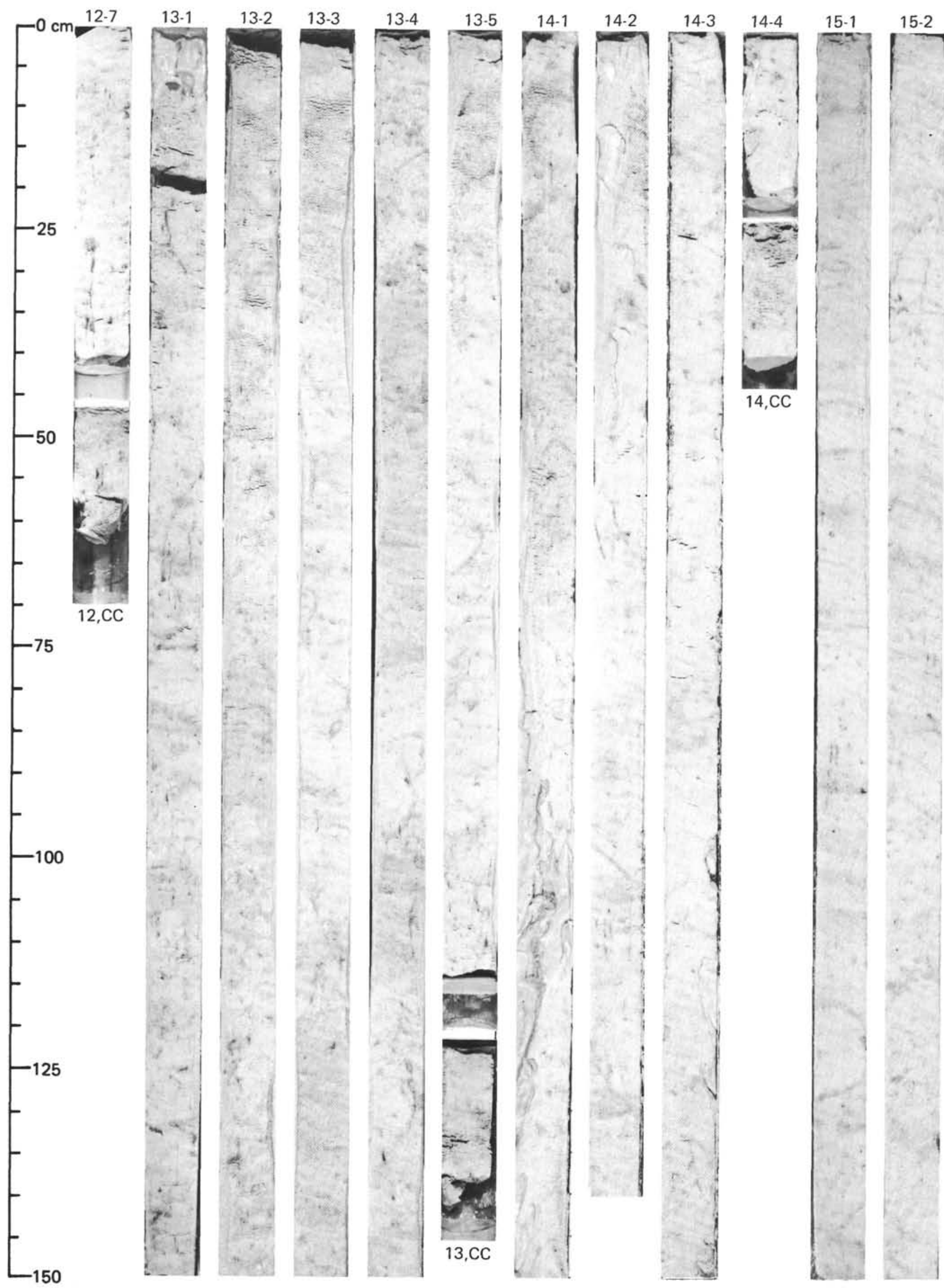




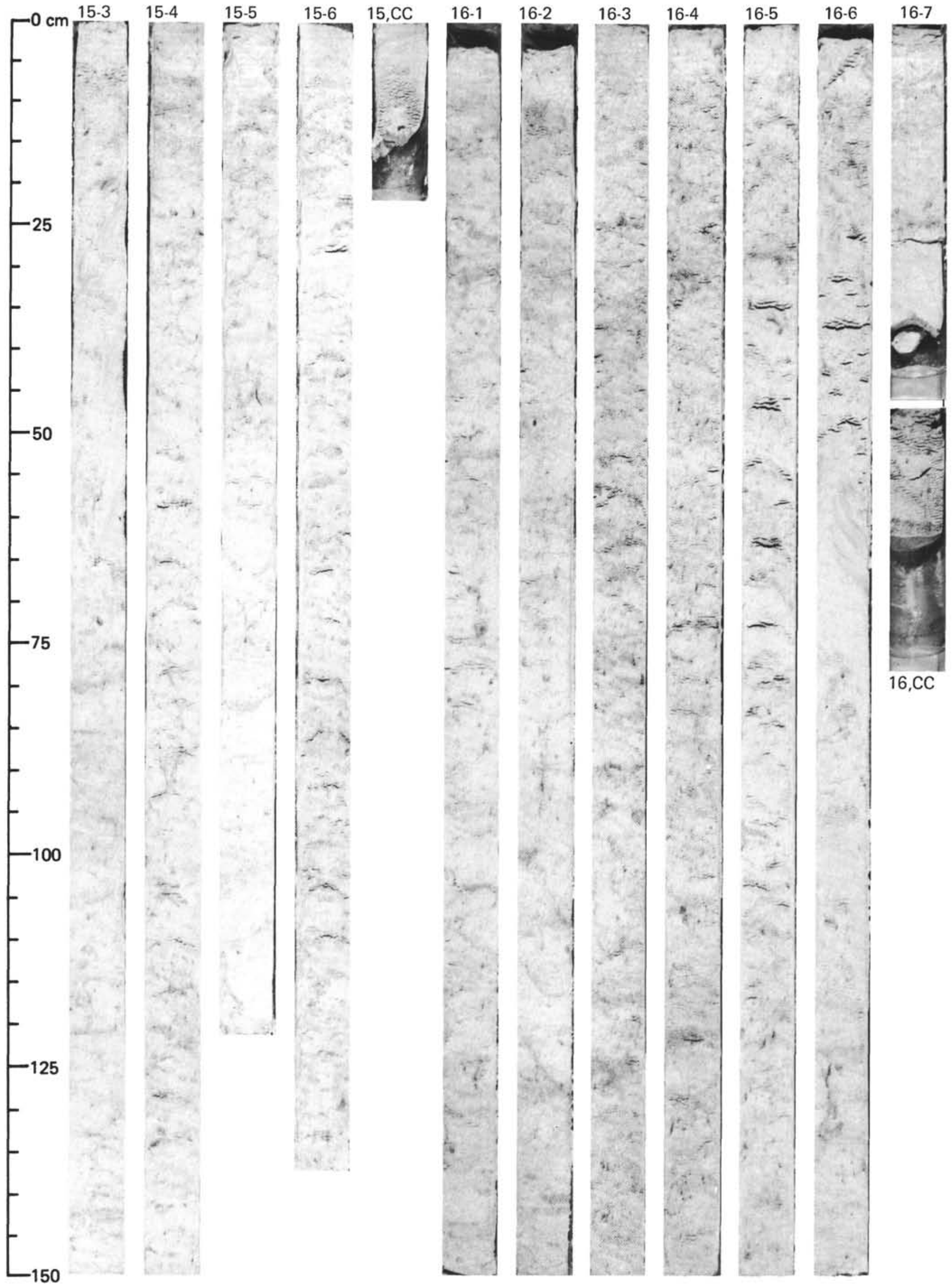




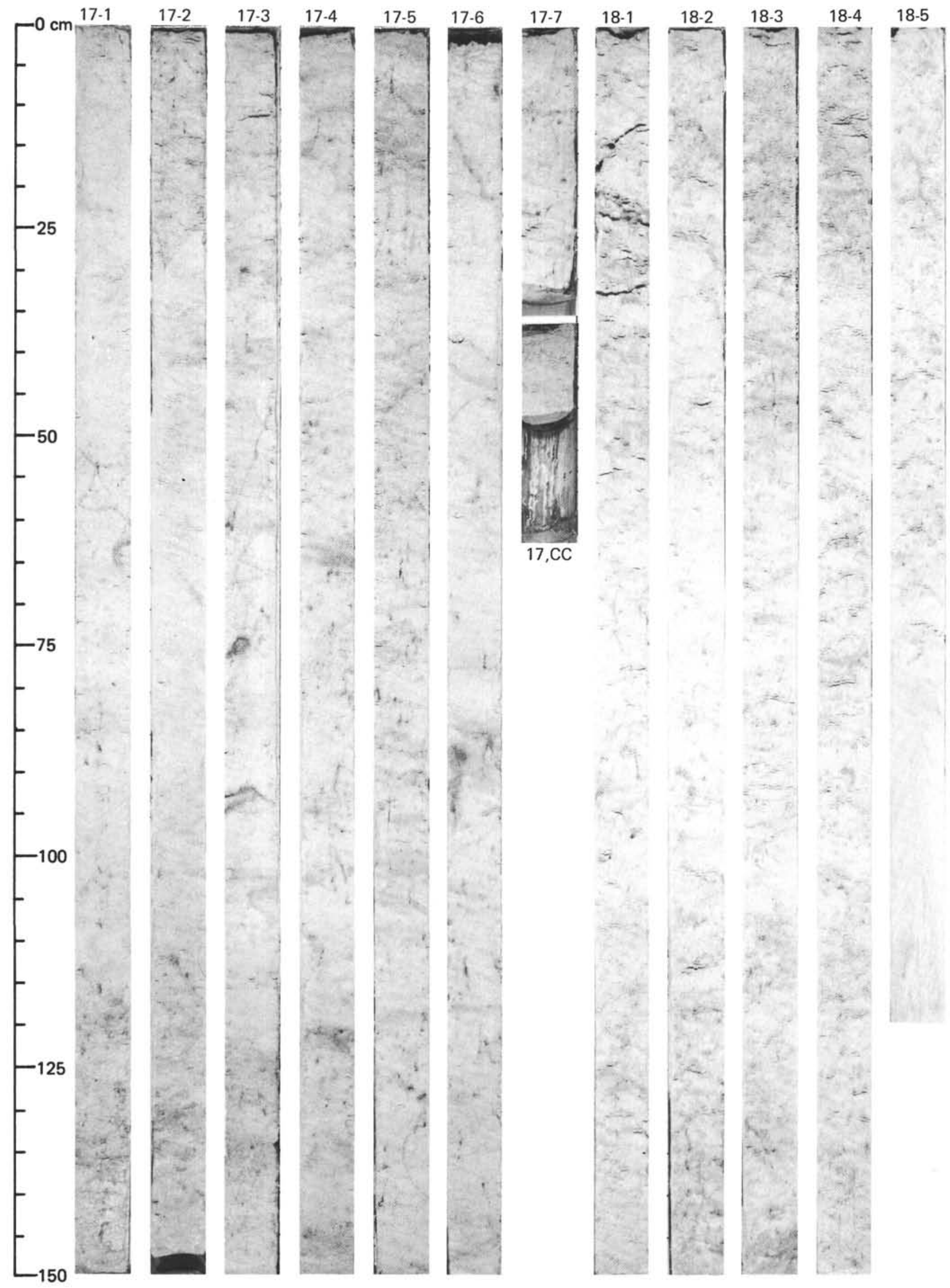




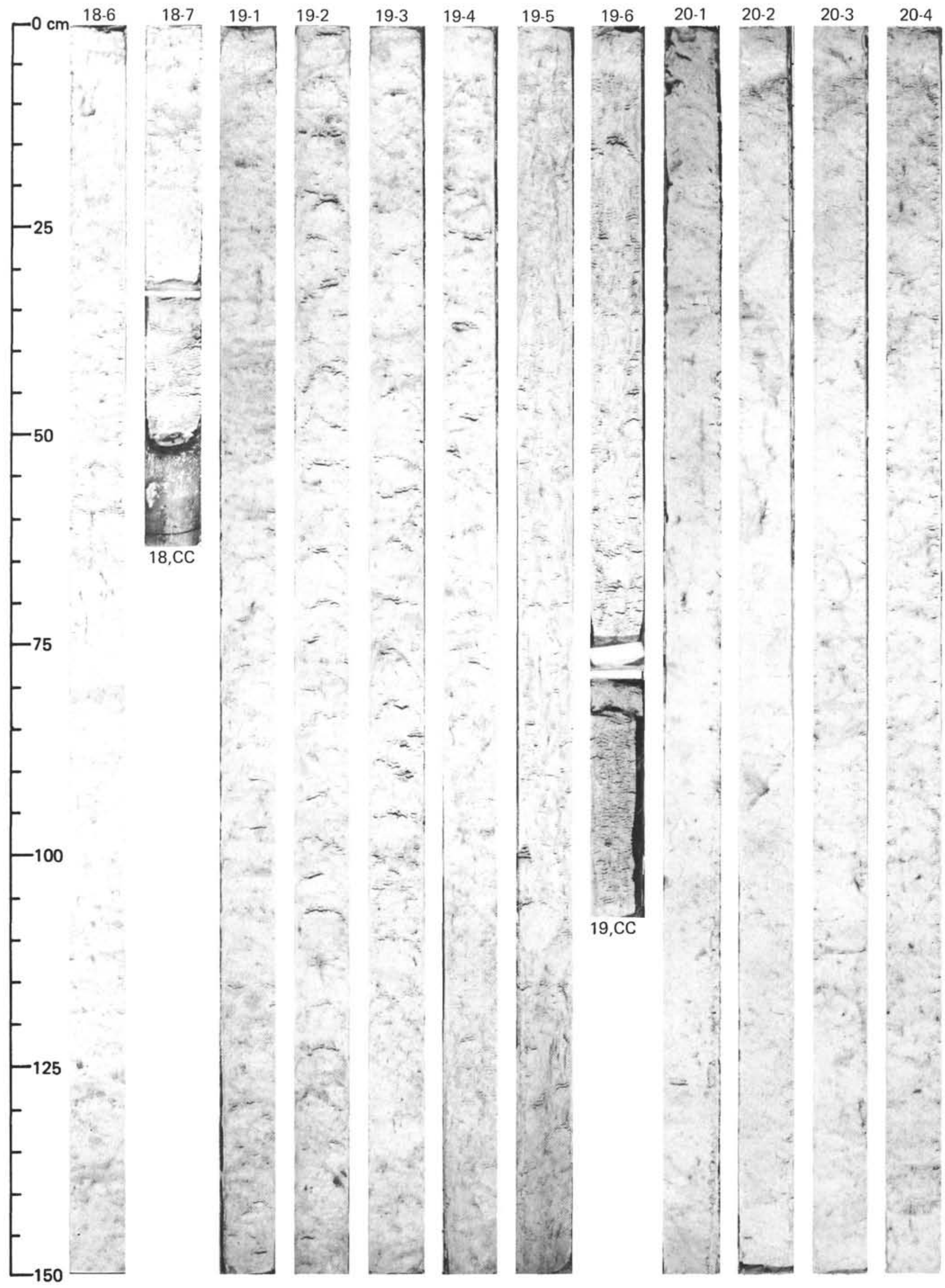




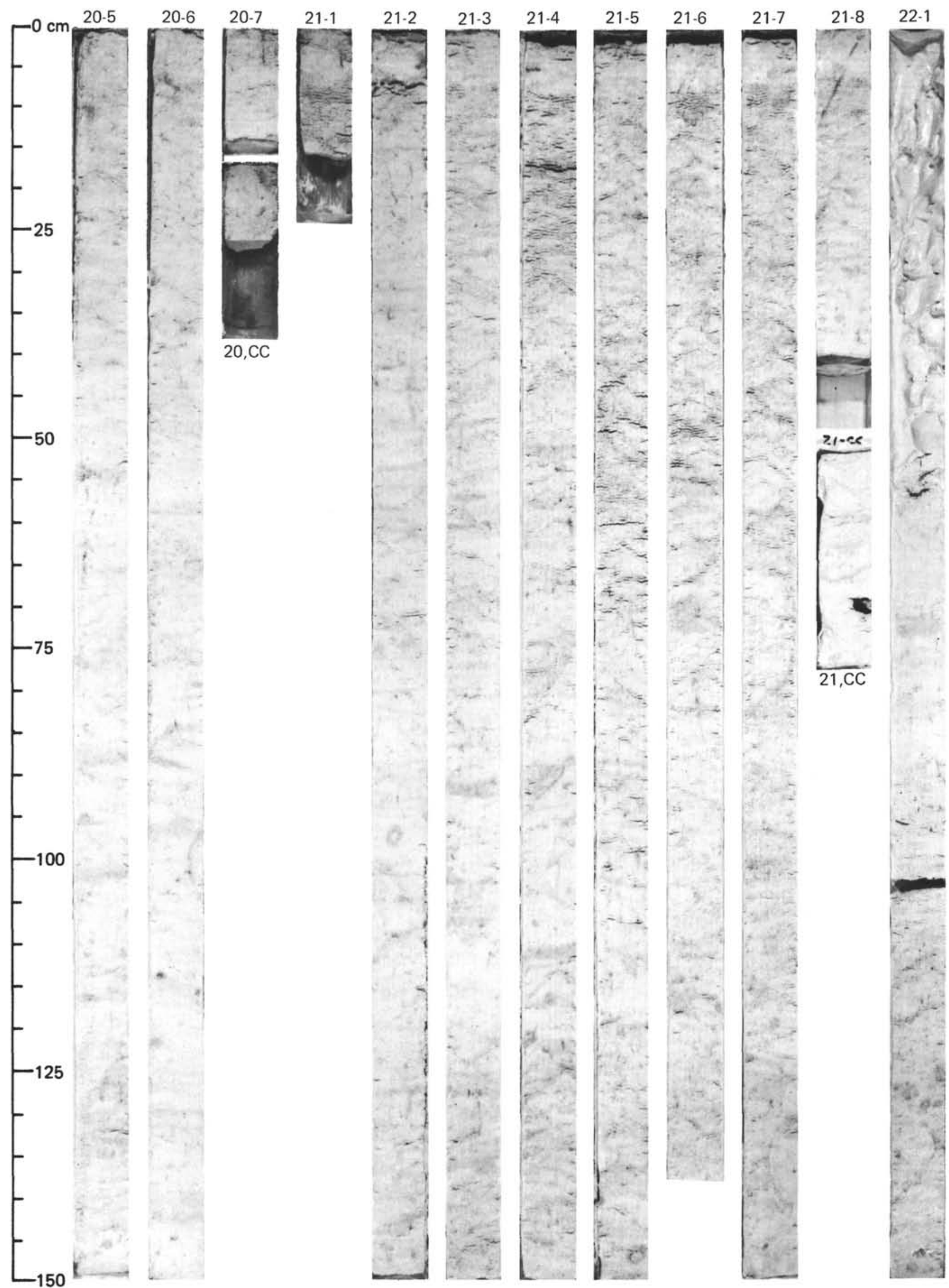




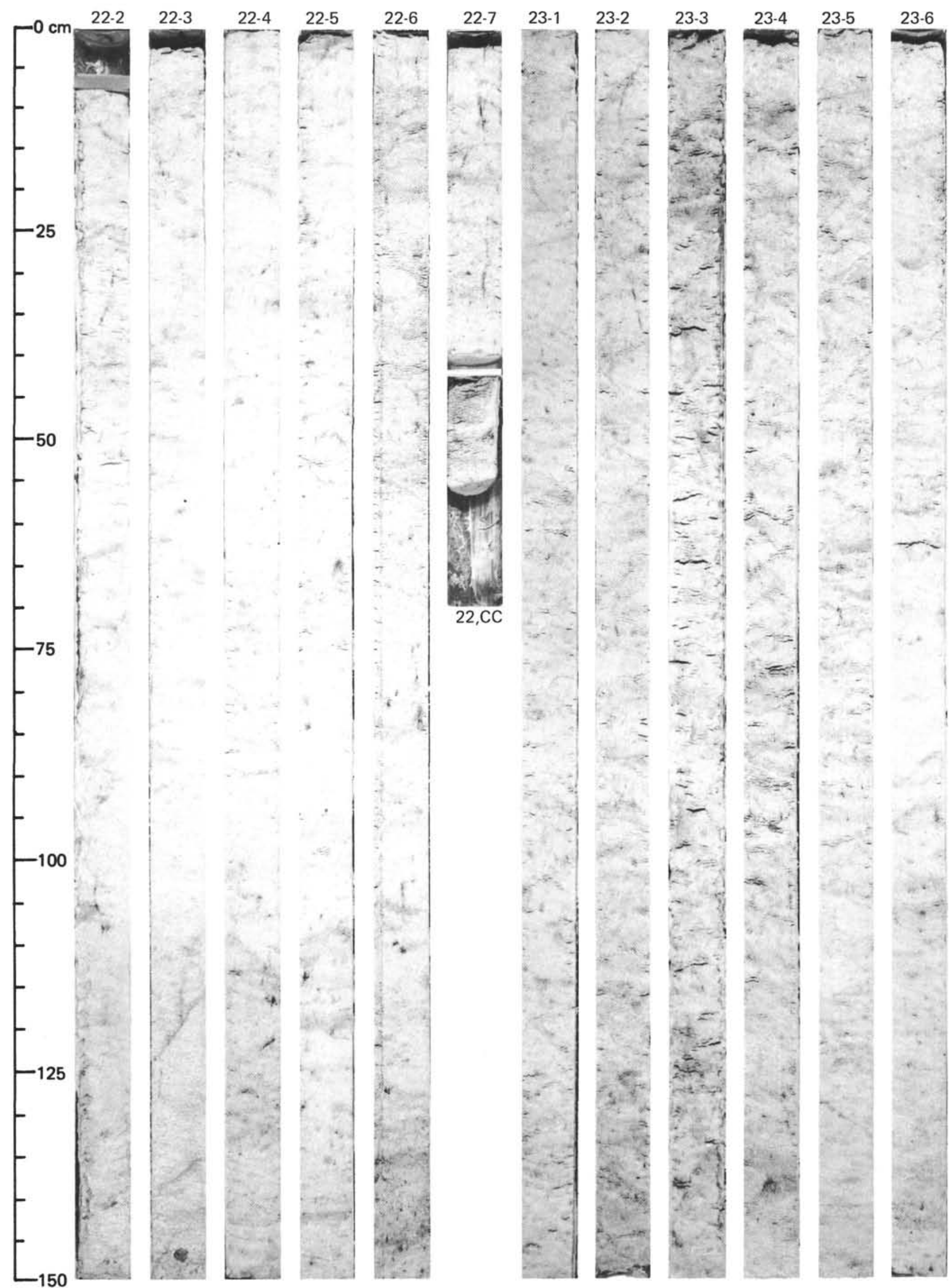




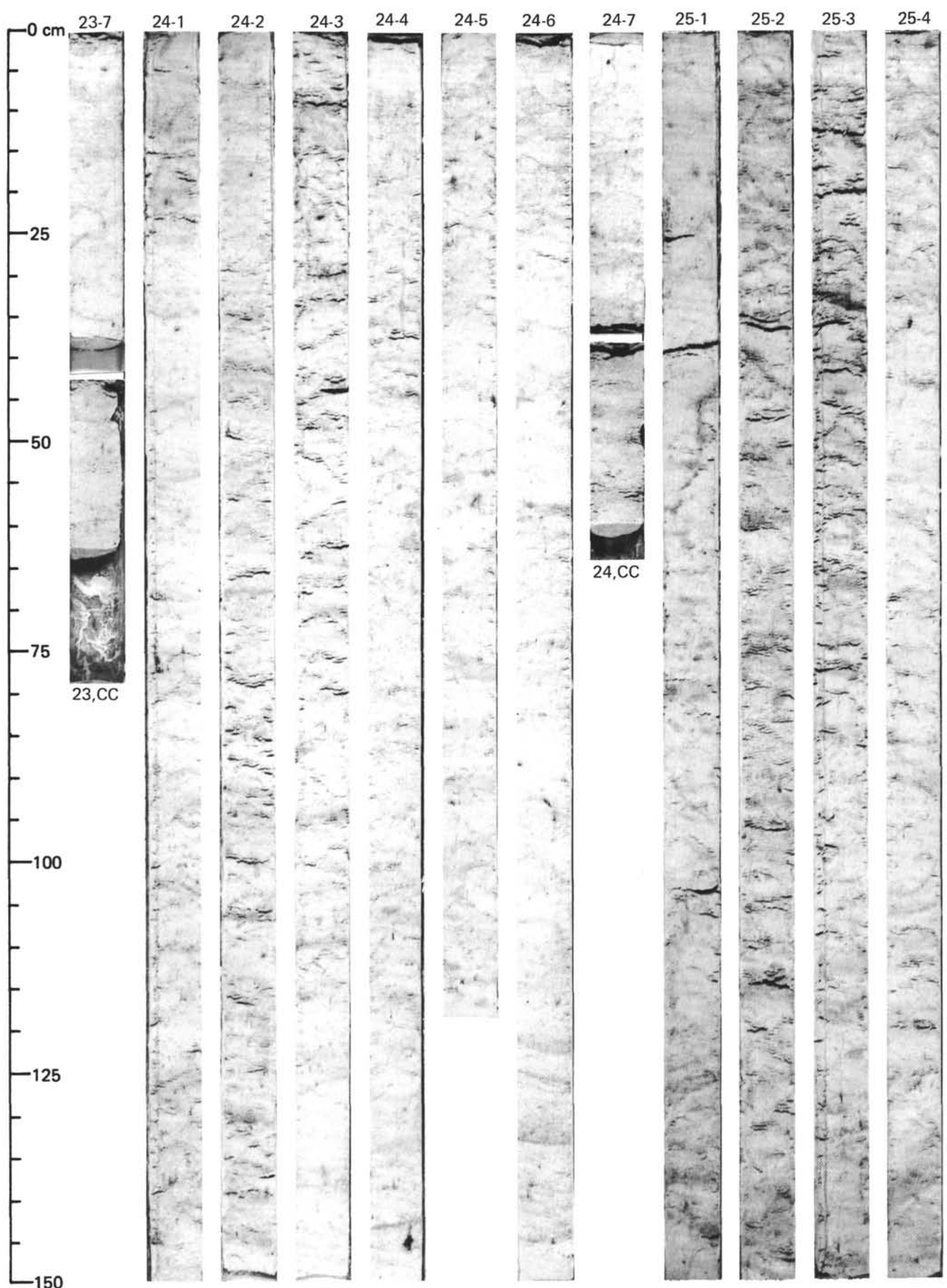




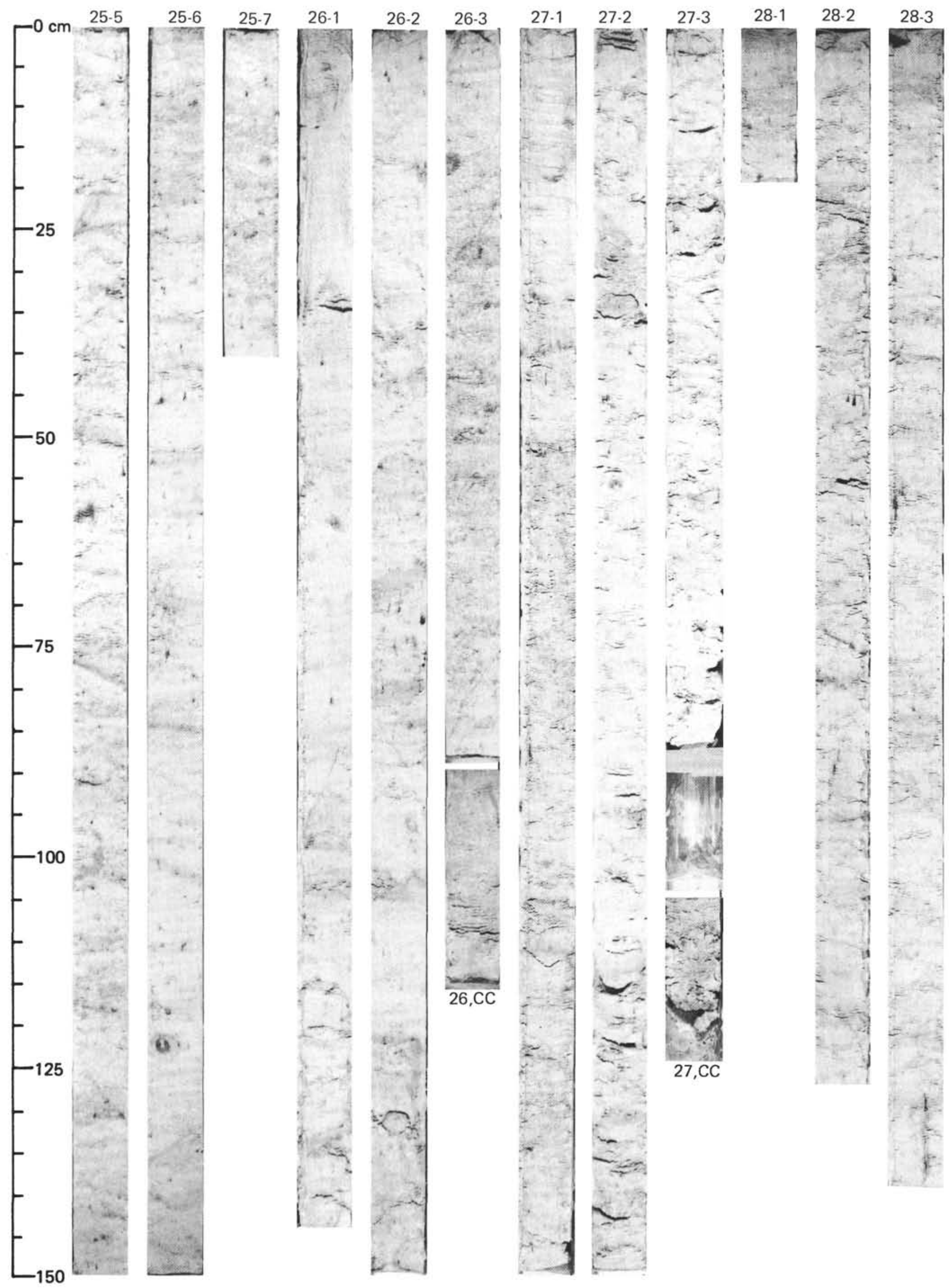




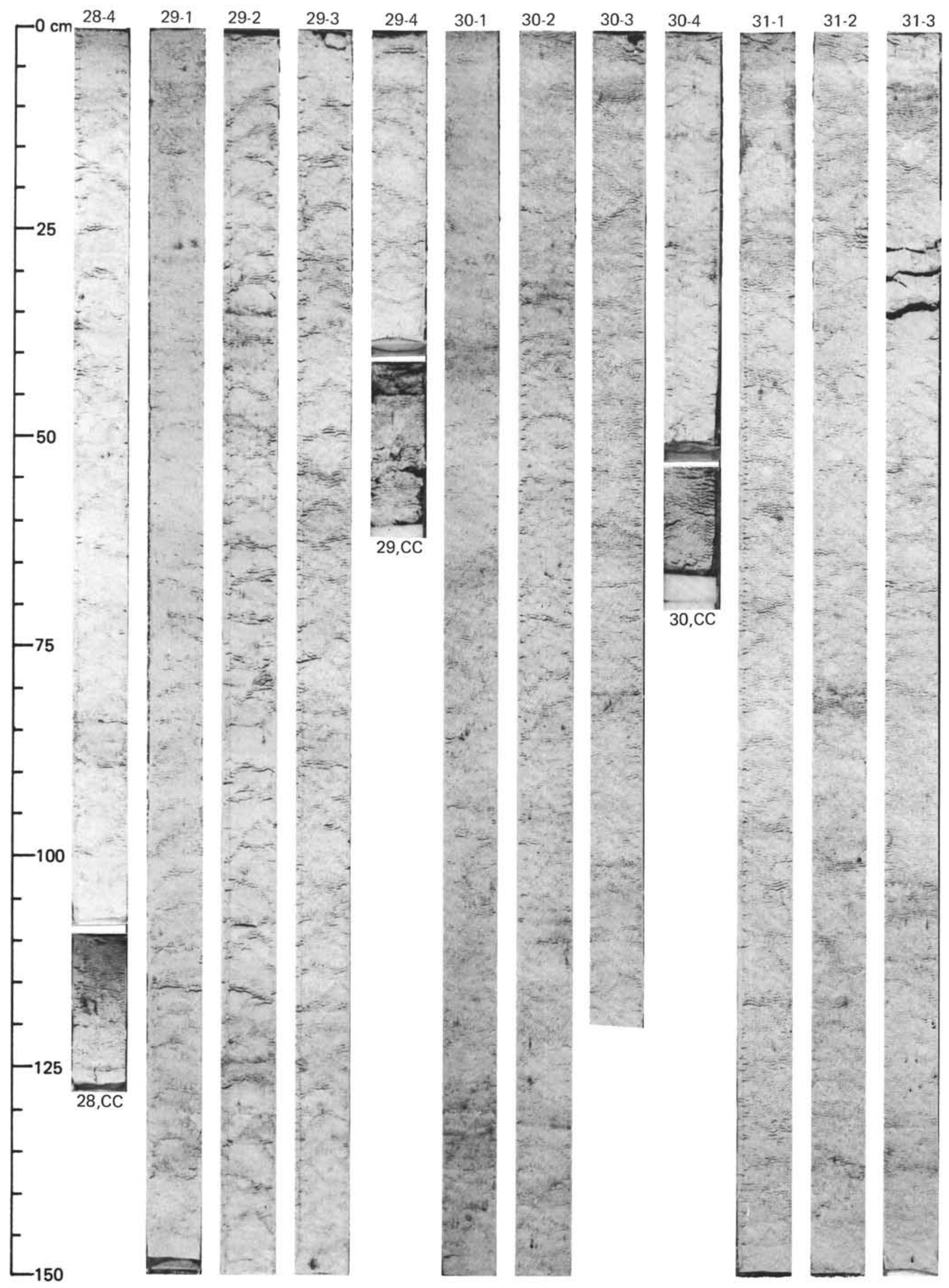


SITE 586 (HOLE 586A)

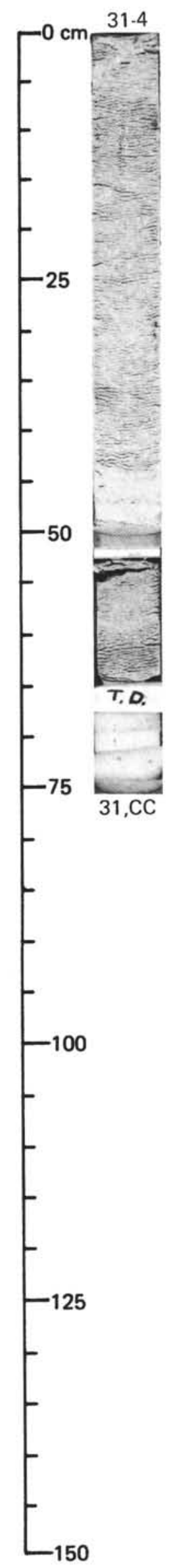




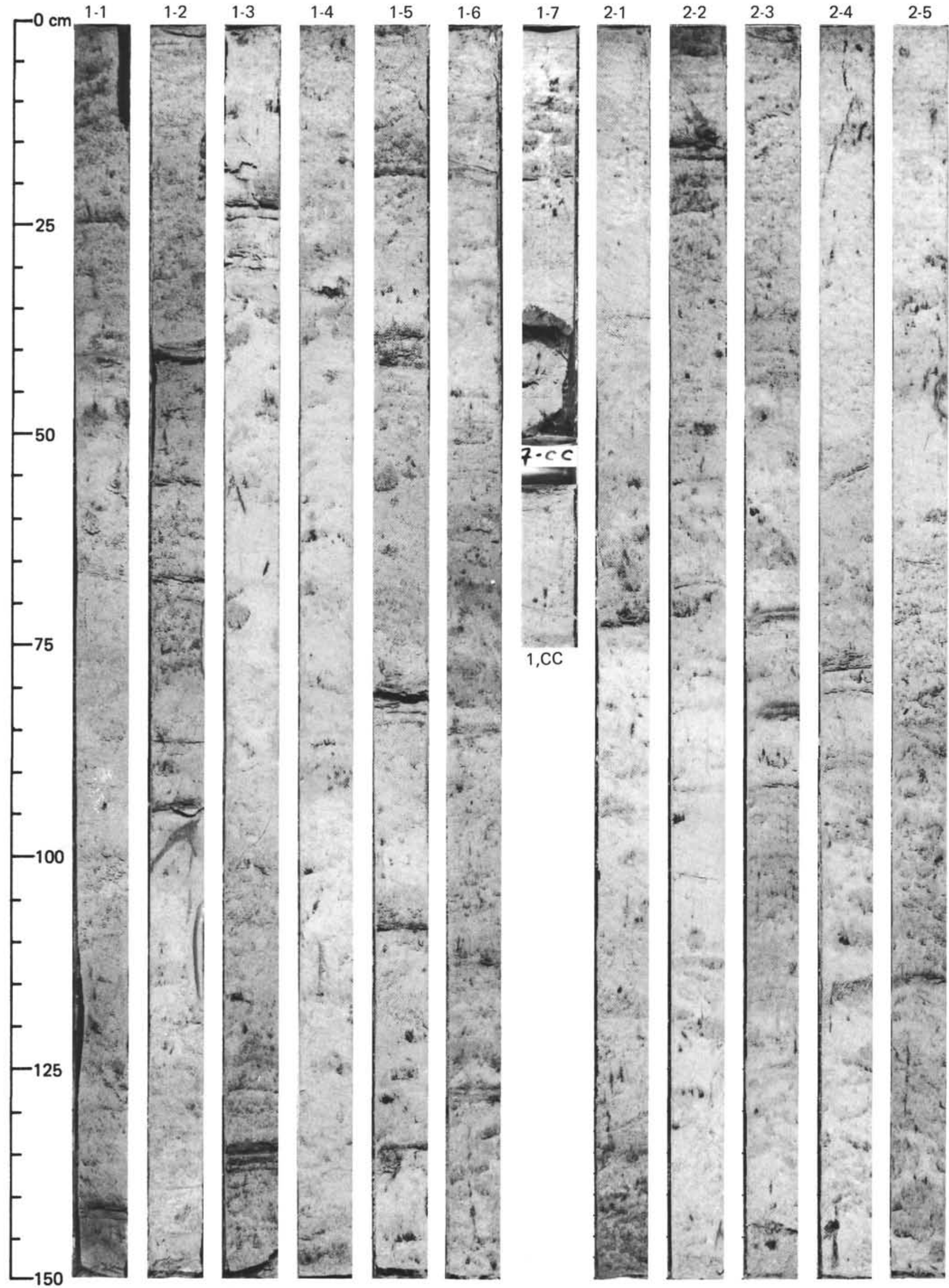




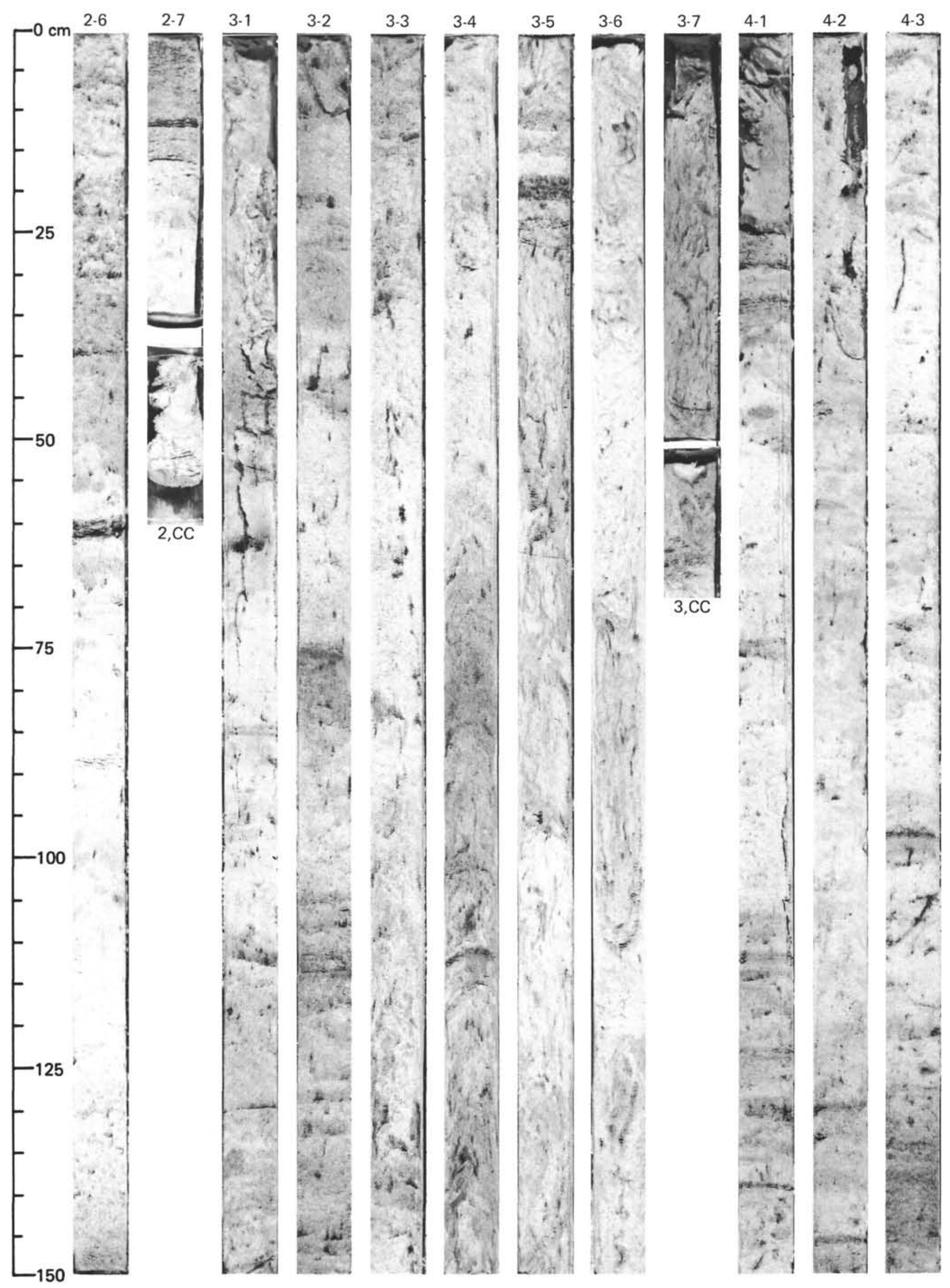




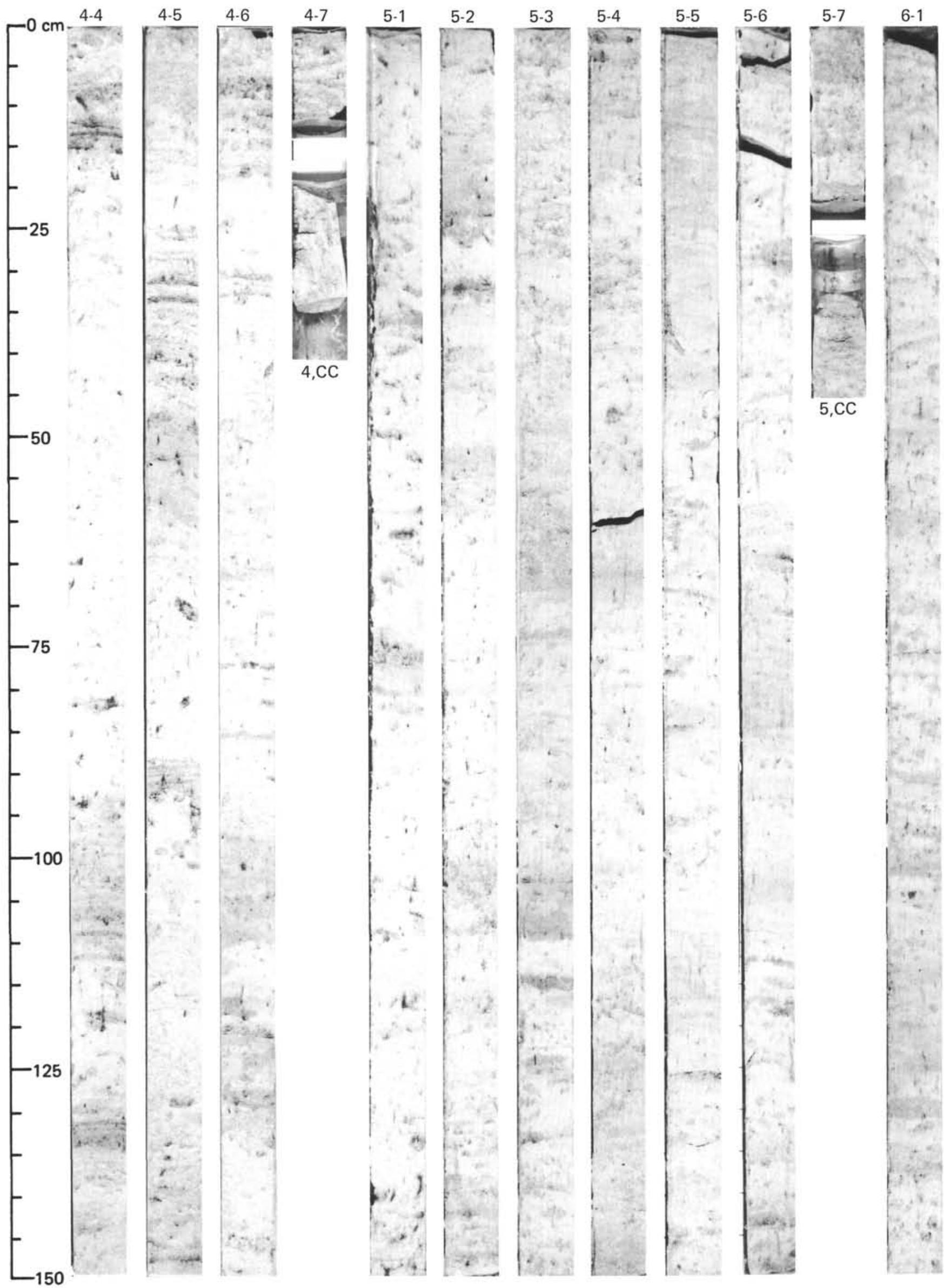




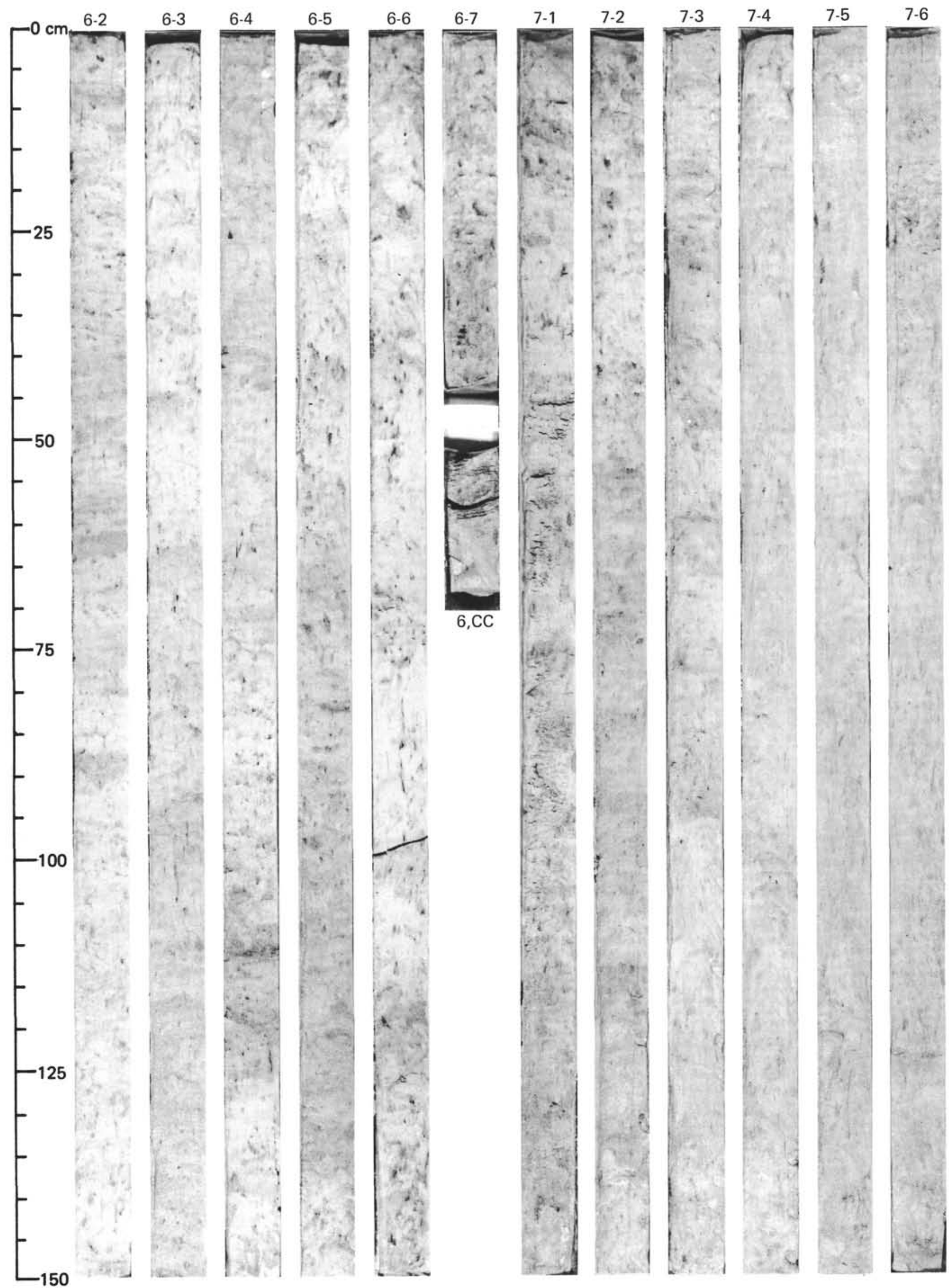


SITE 586 (HOLE 586B)

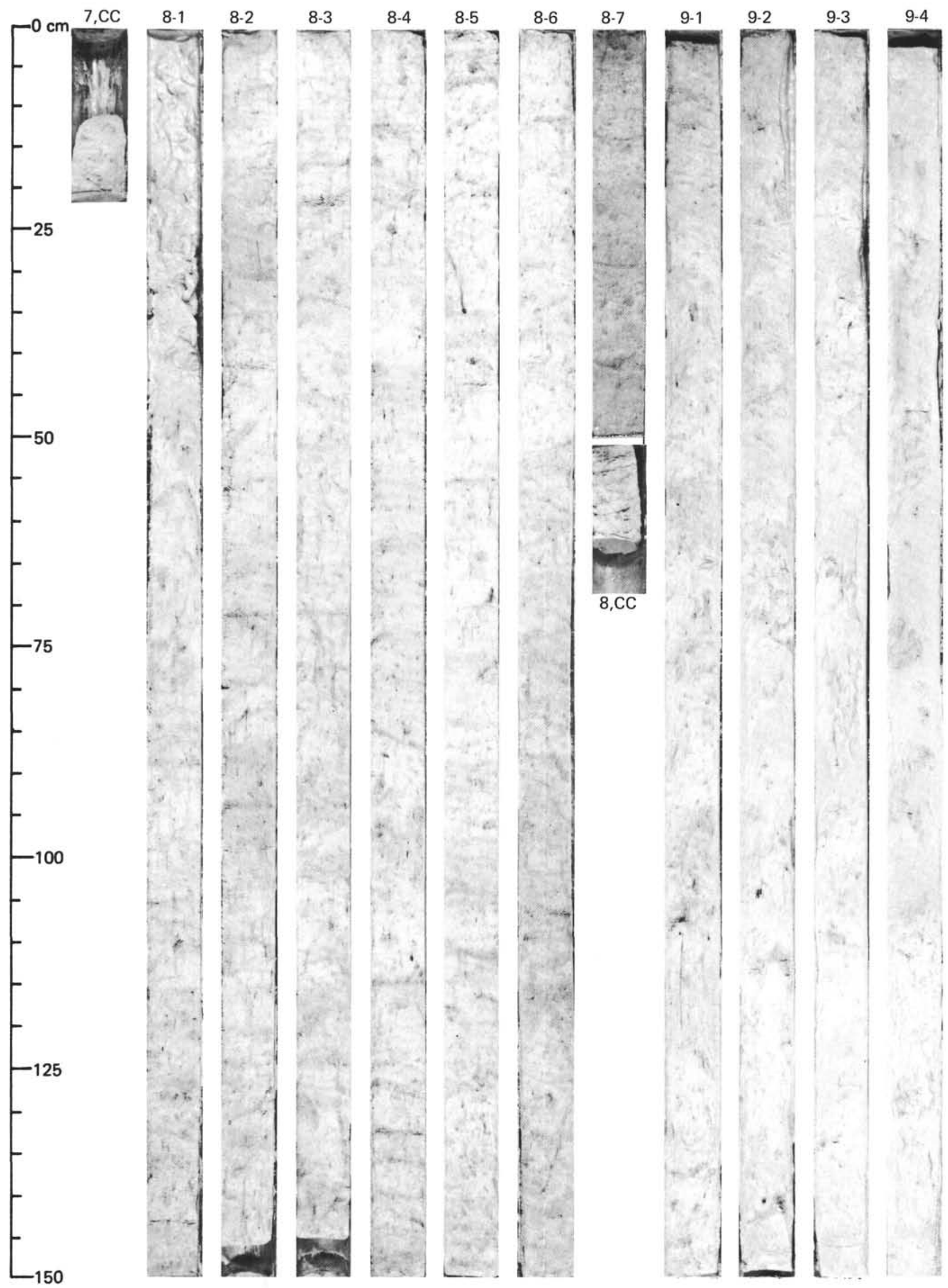




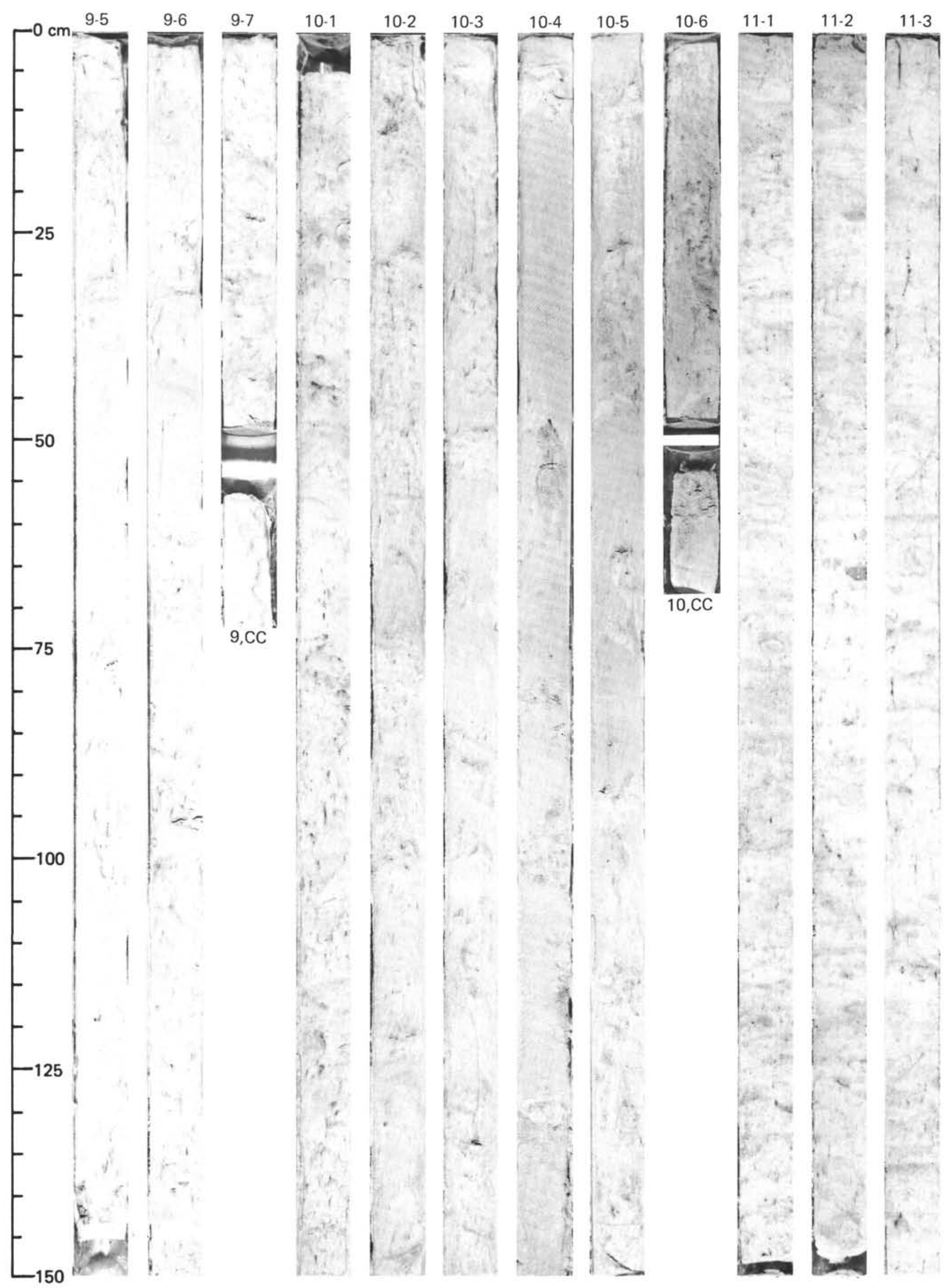


SITE 586 (HOLE 586B)

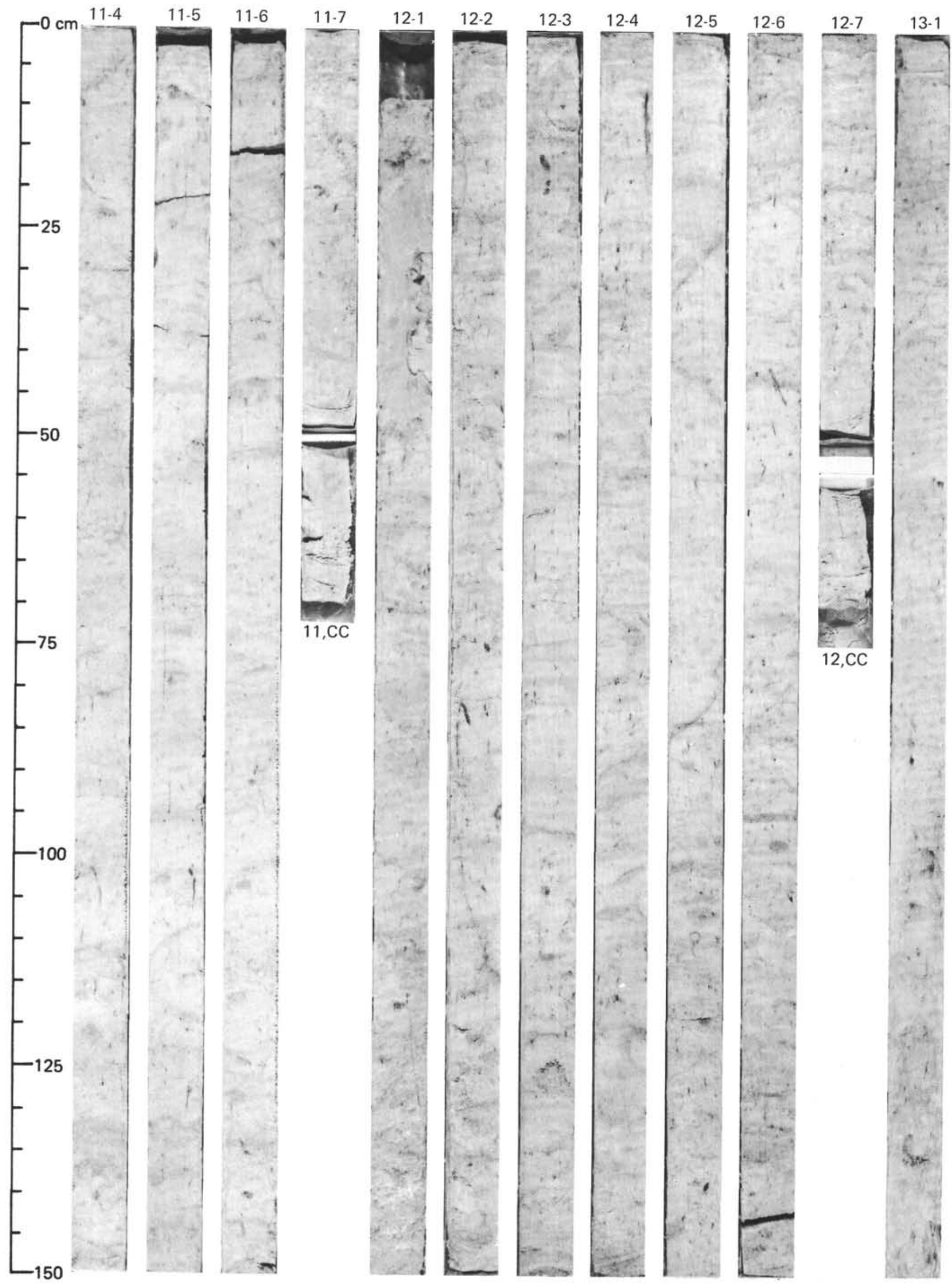


SITE 586 (HOLE 586B)

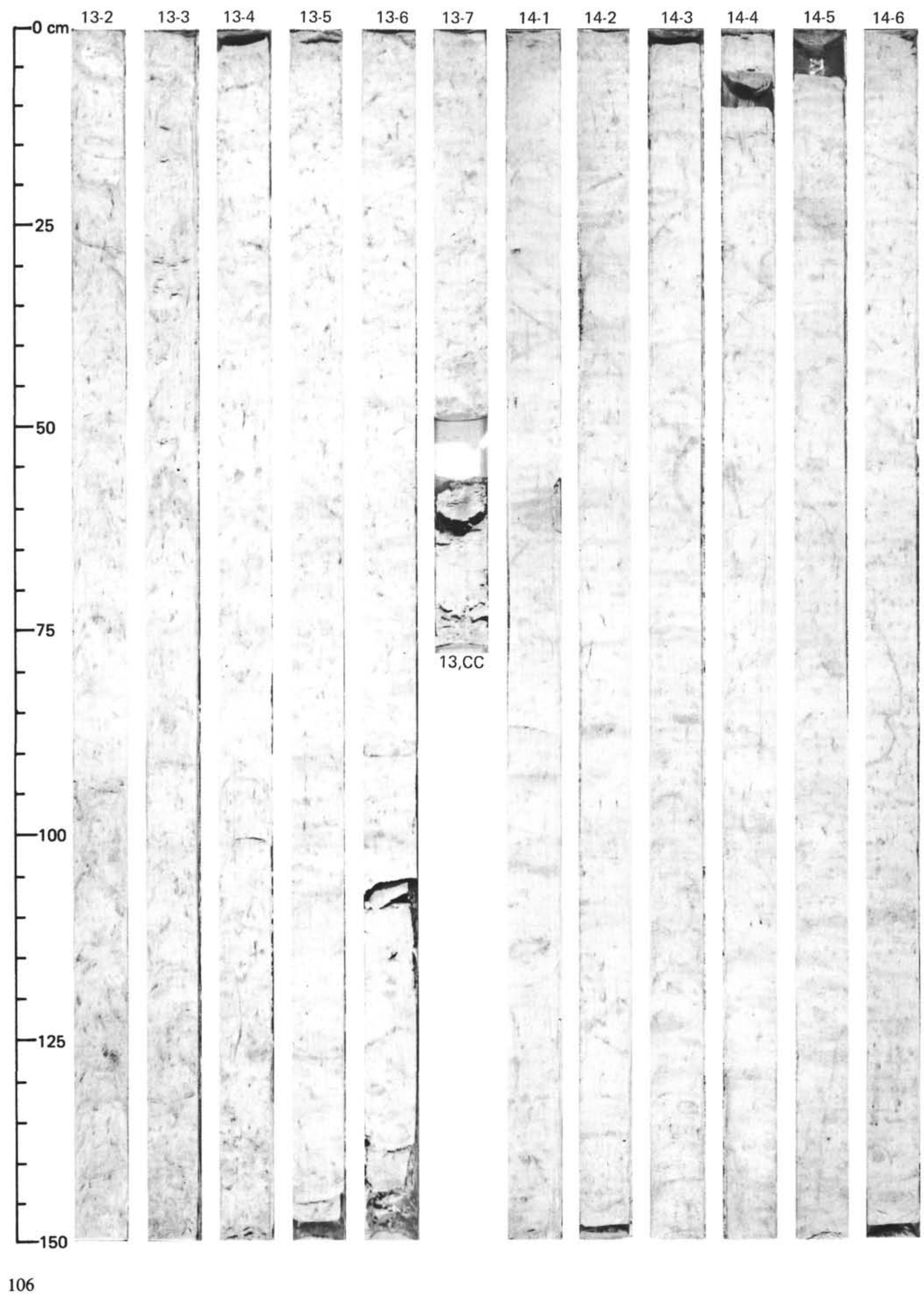




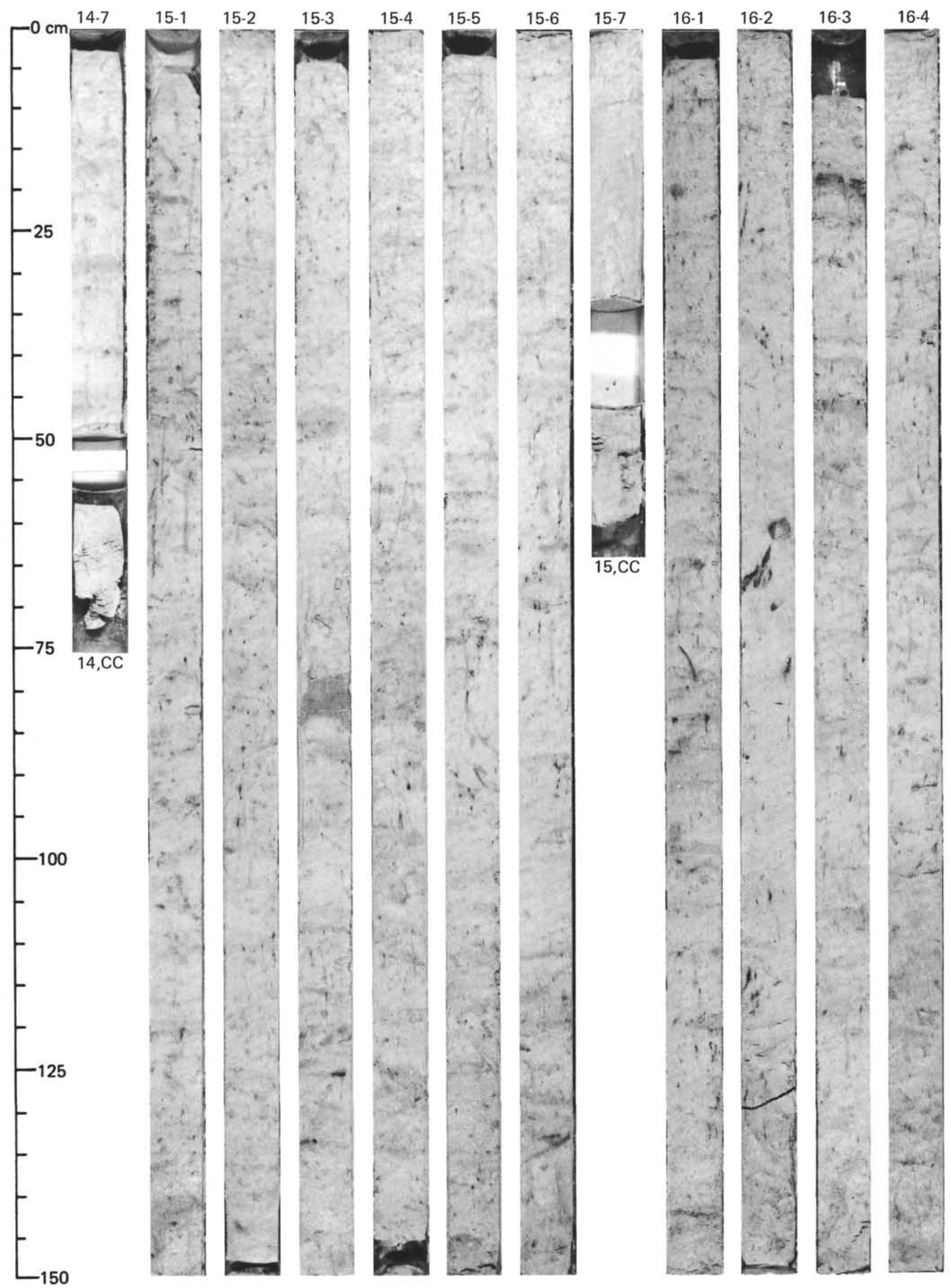




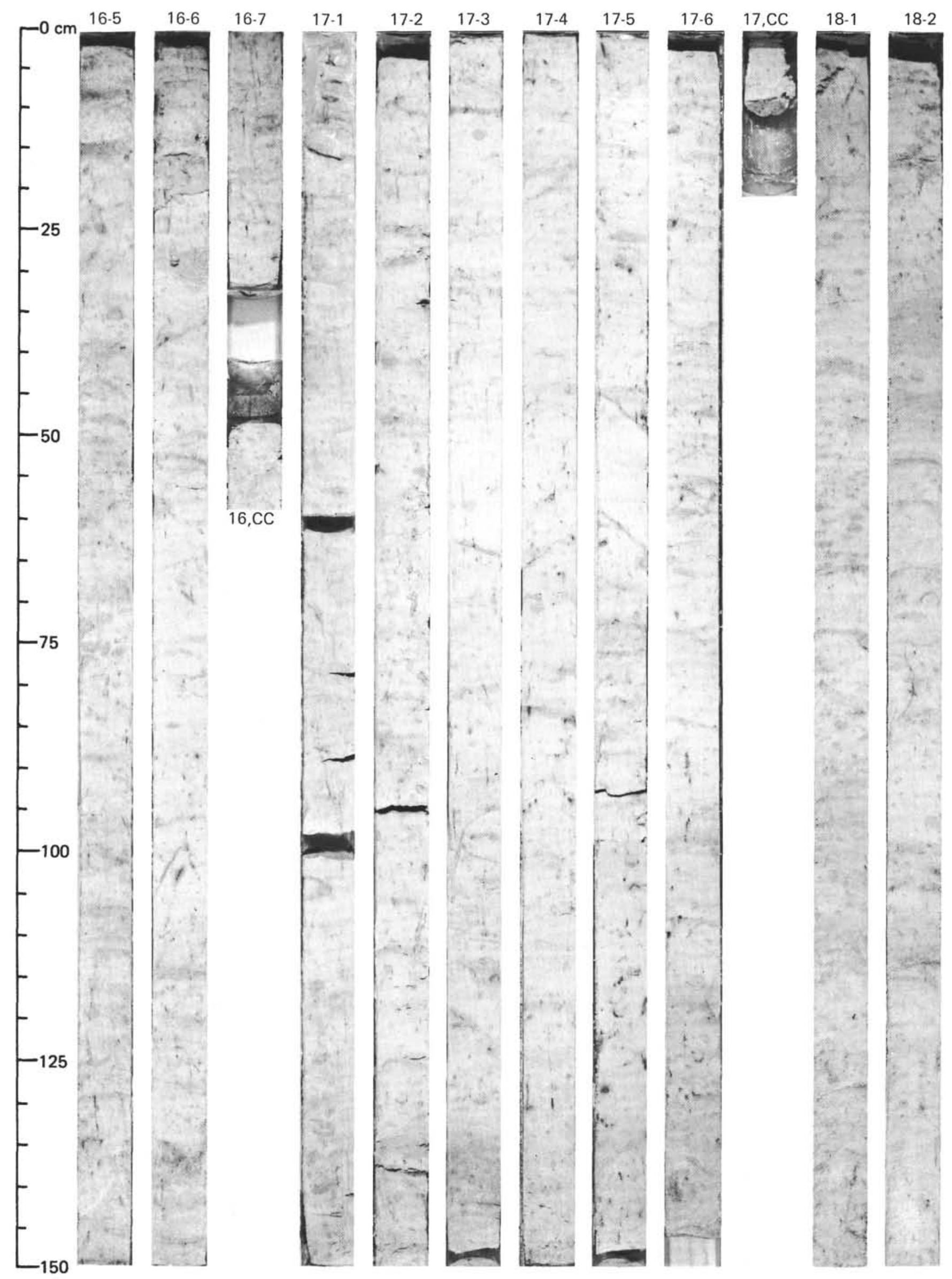


SITE 586 (HOLE 586B)

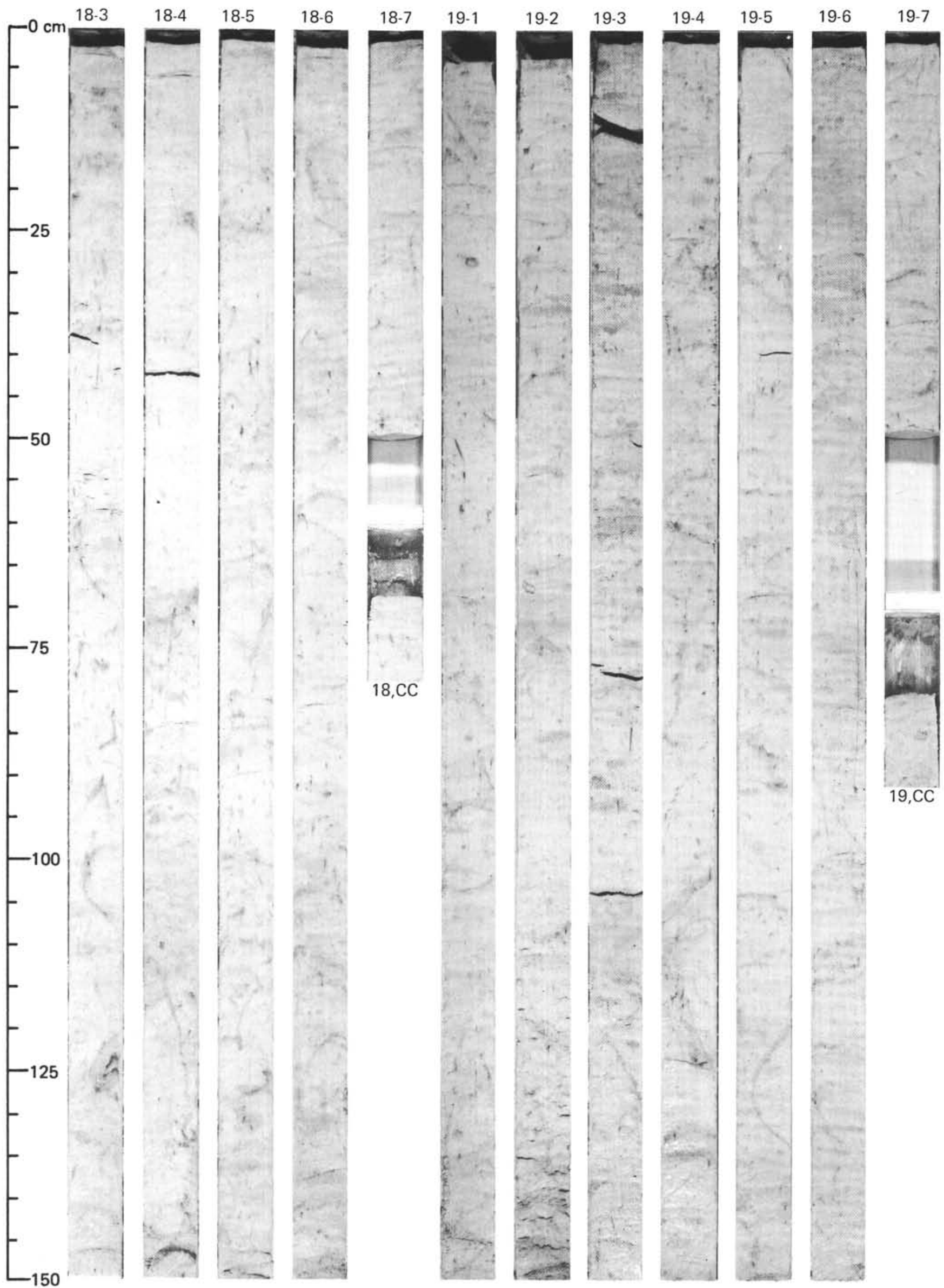




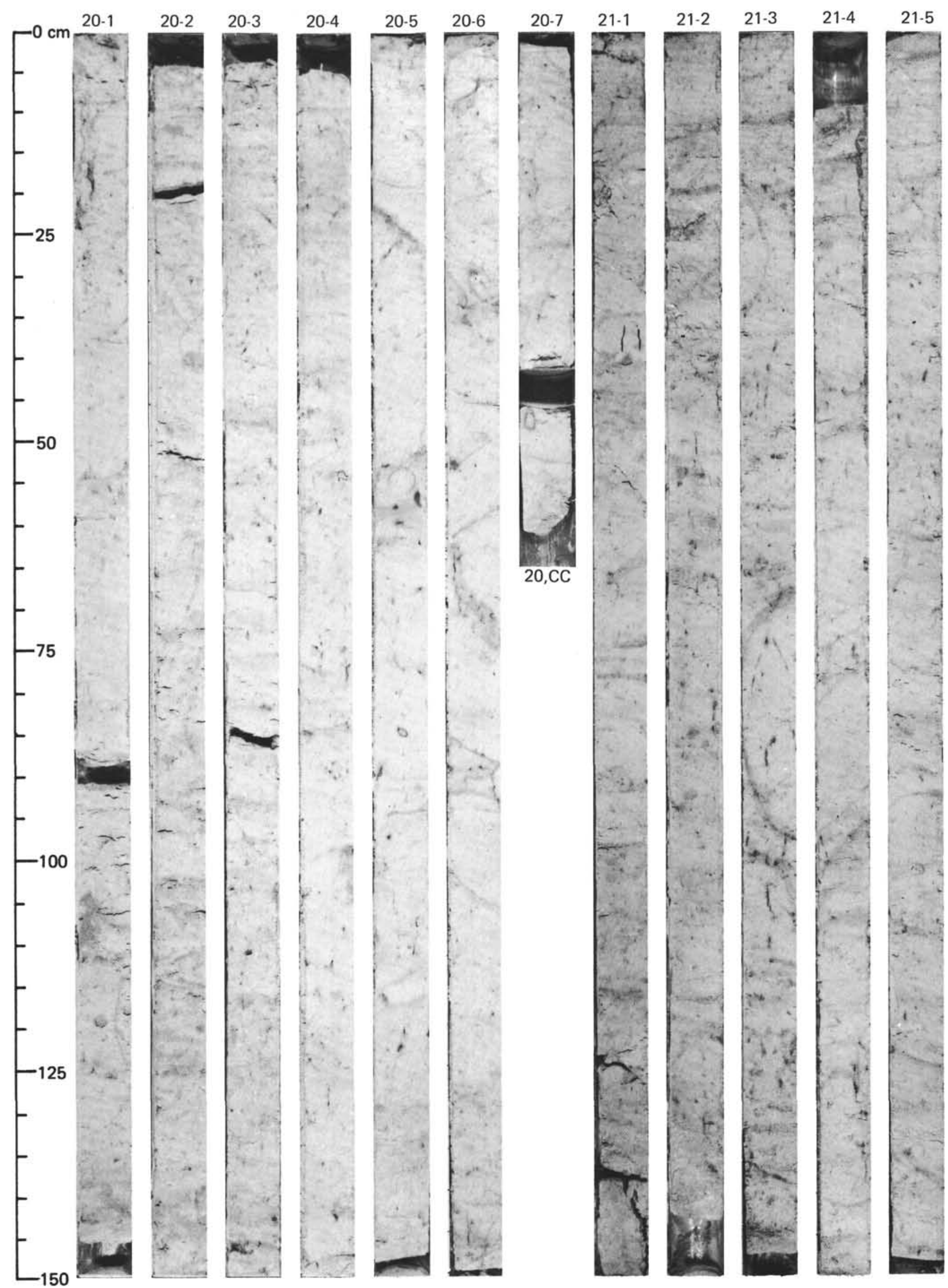




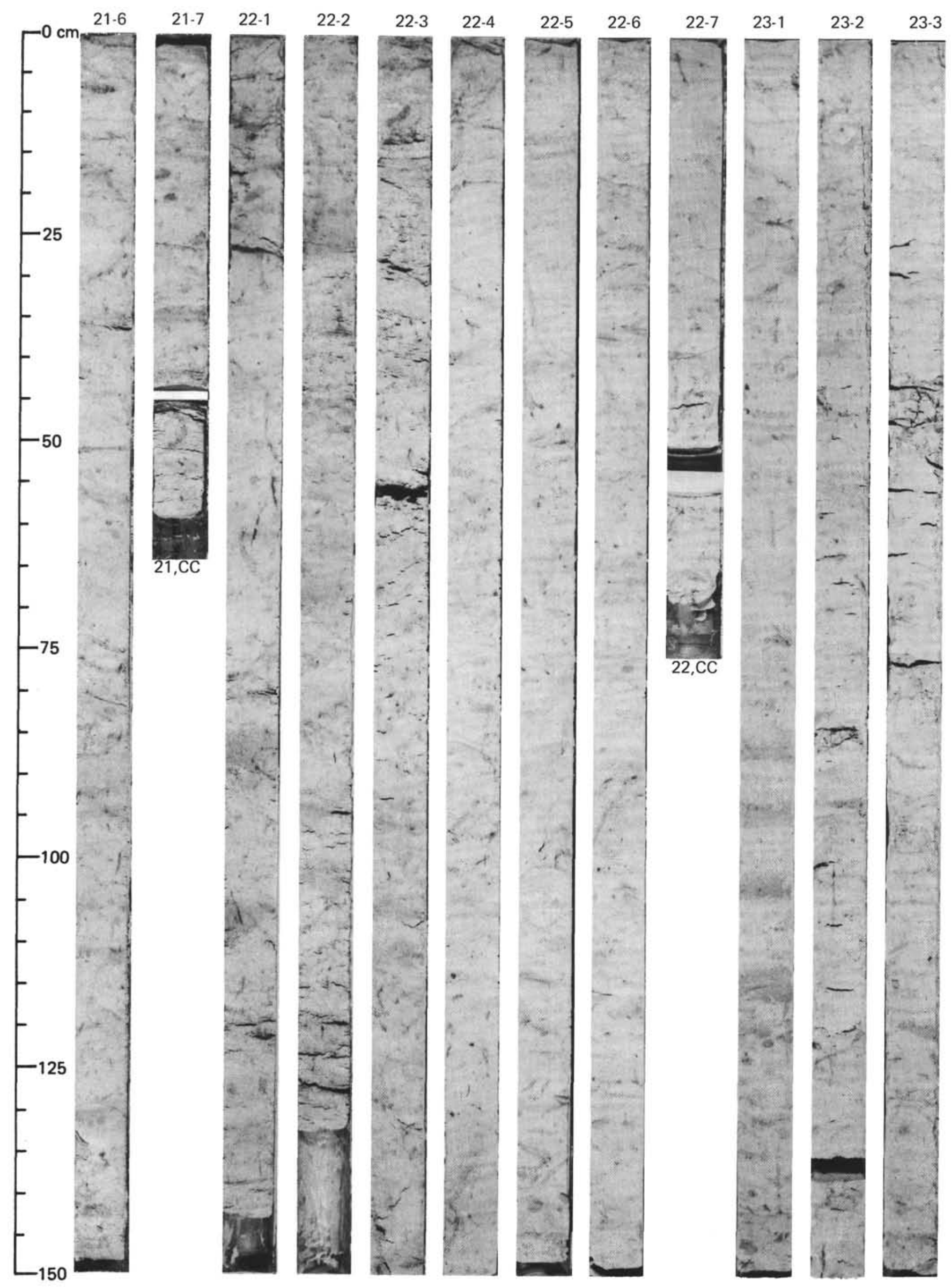


SITE 586 (HOLE 586B)

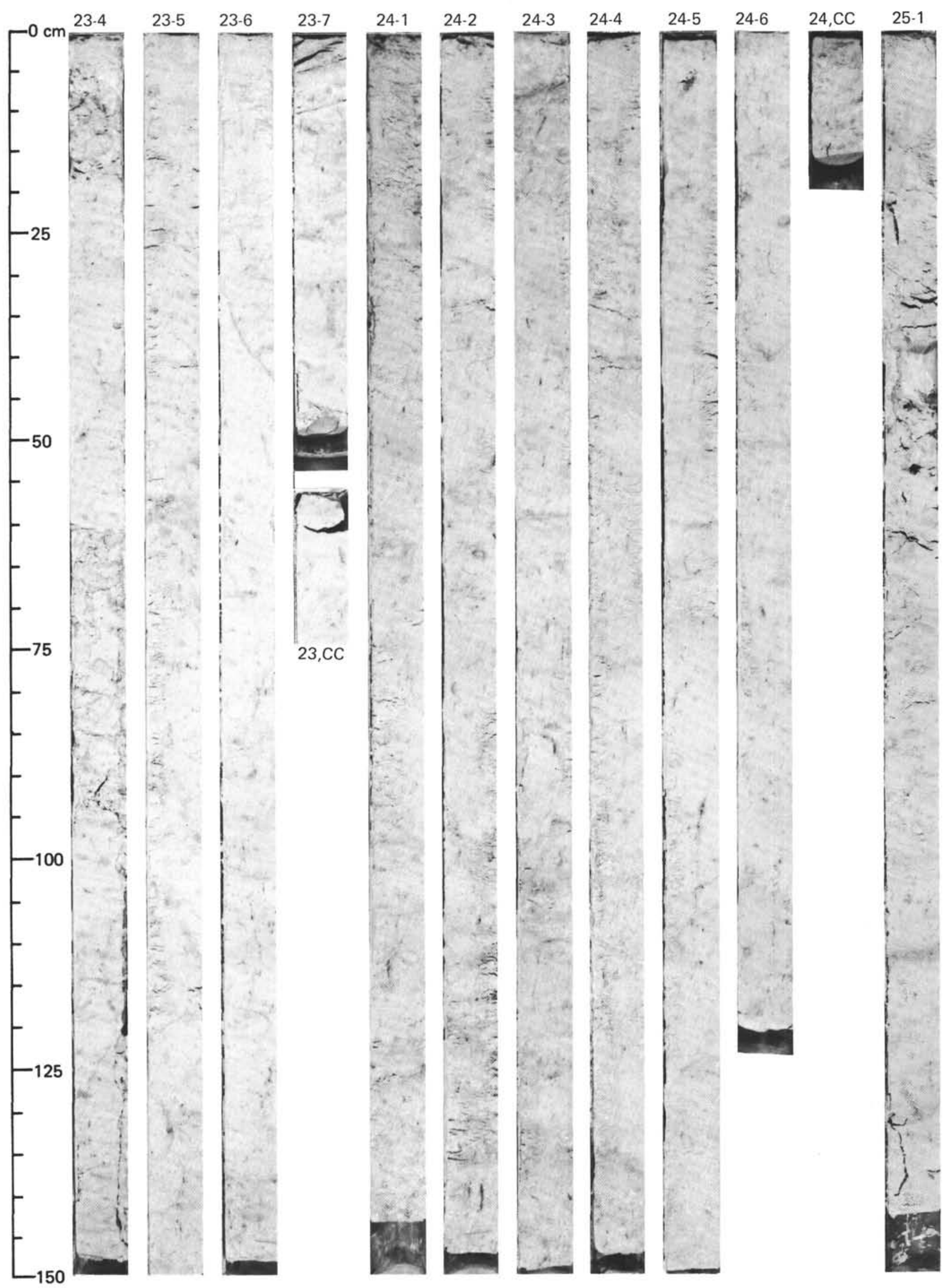




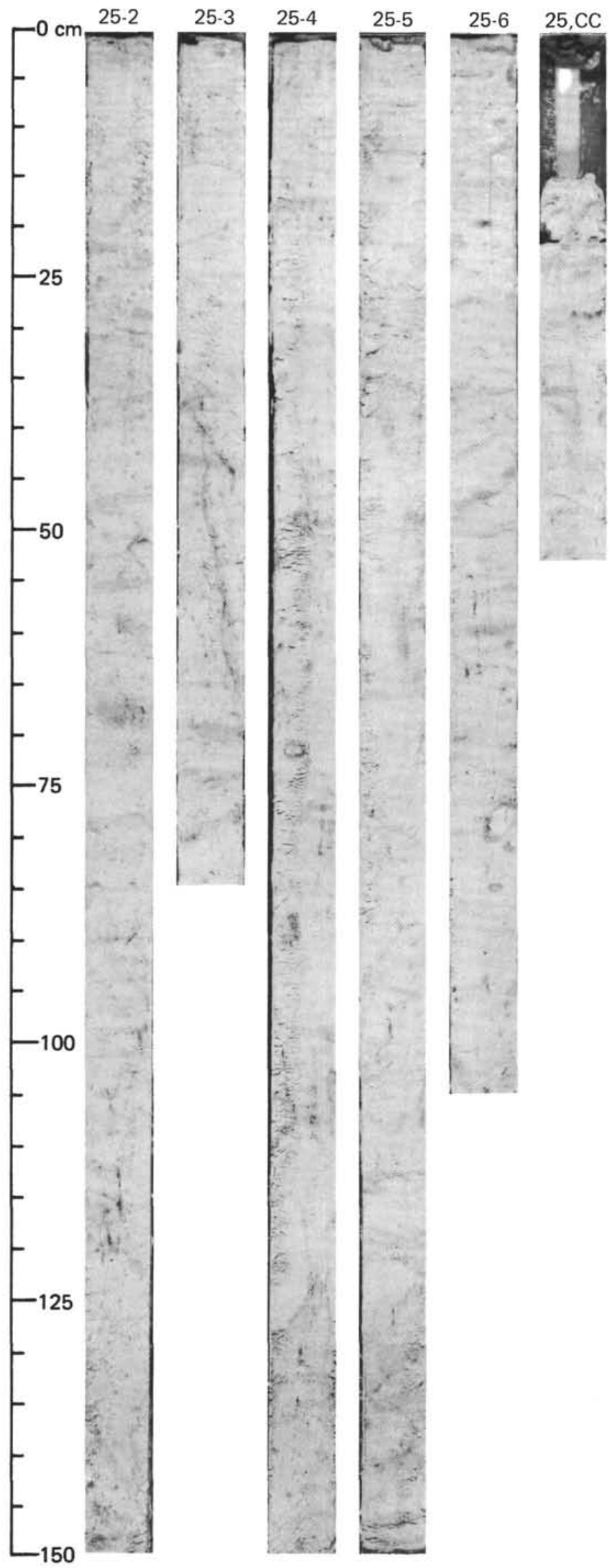


SITE 586 (HOLE 586C)

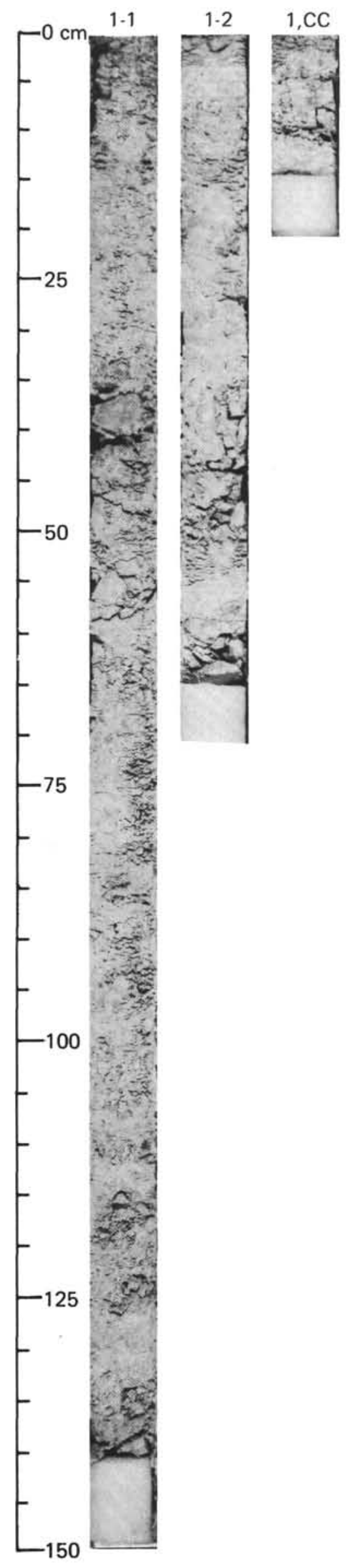

